\title{
Exploring Cyclization Strategies to Access Stemona Alkaloids: Subtle Effects Influencing Reactivity in Intramolecular Michael Additions
}

\author{
Wesley J. Olivier, ${ }^{a}$ Rasool BabaAhmadi, ${ }^{a}$ Nigel T. Lucas, ${ }^{b}$ Alireza Ariafard, ${ }^{a}$ Alex C. \\ Bissember, ${ }^{a *}$ Jason A. Smith ${ }^{\text {** }}$ \\ a School of Natural Sciences - Chemistry, University of Tasmania, Hobart, Tasmania, Australia. \\ ${ }^{b}$ Department of Chemistry, University of Otago, Dunedin, Otago, 9054, New Zealand.
}

Correspondence to: alex.bissember@utas.edu.au; jason.smith@utas.edu.au

\section{Supporting Information}

\section{Table of Contents}

$\begin{array}{llc}\text { I. } & \text { General } & \mathrm{S}-1 \\ \text { II. Synthesis of Compounds } & \mathrm{S}-2 \\ \text { III. Additional Experiments } & \mathrm{S}-10 \\ \text { IV. X-Ray Crystallographic Data } & \mathrm{S}-17 \\ \text { V. Computational Details } & \mathrm{S}-18 \\ \text { VI. NMR Spectra } & \mathrm{S}-45\end{array}$

\section{General}

NMR spectroscopic experiments were performed either on a Bruker Avance III NMR spectrometer operating at $400 \mathrm{MHz}\left({ }^{1} \mathrm{H}\right)$ or $100 \mathrm{MHz}\left({ }^{13} \mathrm{C}\right)$ or on a Bruker Avance III NMR spectrometer operating at $600 \mathrm{MHz}\left({ }^{1} \mathrm{H}\right)$ or $150 \mathrm{MHz}\left({ }^{13} \mathrm{C}\right)$. The deuterated solvents used were $\mathrm{CDCl}_{3}, \mathrm{CD}_{3} \mathrm{OD}$, $\mathrm{CD}_{3} \mathrm{CN}$ or acetone- $d_{6}$. Chemical shifts were recorded in ppm. Spectra were calibrated by assignment of the residual solvent peak to $\delta_{\mathrm{H}} 7.26$ and $\delta_{\mathrm{C}} 77.16$ for $\mathrm{CDCl}_{3} ; \delta_{\mathrm{H}} 3.31$ and $\delta_{\mathrm{C}} 49.00$ for $\mathrm{CD}_{3} \mathrm{OD} ; \delta_{\mathrm{H}} 1.94$ and $\delta \mathrm{c} 1.32$ for $\mathrm{CD}_{3} \mathrm{CN}$ and $\delta_{\mathrm{H}} 2.05$ and $\delta_{\mathrm{c}} 29.84$ for acetone- $d_{6} .{ }^{1}$ Coupling constants $(J)$ were recorded in $\mathrm{Hz}$. Unless otherwise specified, all NMR experiments were performed at $25{ }^{\circ} \mathrm{C}$. Infrared spectroscopy was performed on a Shimadzu FTIR 8400s spectrometer, with samples analyzed as thin films on $\mathrm{NaCl}$ or $\mathrm{KBr}$ plates following evaporation of the solvent from $\mathrm{CH}_{2} \mathrm{Cl}_{2}, \mathrm{CDCl}_{3}$ or acetone- $d_{6}$ solutions. A Q-Exactive HF Orbitrap (Thermo Scientific) equipped with HESI interface was used for high resolution mass spectrometry (HRMS) analysis of all compounds. Samples were infused by syringe pump at $10 \mu \mathrm{l} / \mathrm{min}$ and spectra were acquired in positive ionization mode at a spray voltage of $3.9 \mathrm{kV}$, capillary temperature of 320 degrees and sheath gas flow of $6 \mathrm{AU}$. Spectra were matched to isotopic simulations using Qual Browser software (Thermo Scientific) using Gaussian output style at 120,000 resolving power. Polarimetry was performed with a Rudolph Research Analytical Autopol III automatic polarimeter with a $0.5 \mathrm{dm}$ cell.

TLC was performed using Merck silica gel $60-\mathrm{F}_{254}$ plates. Developed TLC plates were visualized by UV absorbance $(254 \mathrm{~nm})$ or through application of heat to a plate stained with cerium molybdate $\left\{\mathrm{Ce}\left(\mathrm{NH}_{4}\right)_{2}\left(\mathrm{NO}_{3}\right)_{6},\left(\mathrm{NH}_{4}\right)_{6} \mathrm{Mo}_{7} \mathrm{O}_{24} \cdot 4 \mathrm{H}_{2} \mathrm{O}, \mathrm{H}_{2} \mathrm{SO}_{4}, \mathrm{H}_{2} \mathrm{O}\right\}$ or potassium permanganate $\left(\mathrm{KMnO}_{4}, \mathrm{~K}_{2} \mathrm{CO}_{3}, \mathrm{H}_{2} \mathrm{O}\right)$. Flash column chromatography was performed with flash grade silica gel $(60 \mu \mathrm{m})$ and the indicated eluent in accordance with standard techniques. ${ }^{2}$ Automated flash column chromatography was conducted with a Reveleris ${ }^{\circledR} \mathrm{X} 2$ flash chromatography system with

1. Fulmer, G. R.; Miller, A. J.; Sherden, N. H.; Gottlieb, H. E.; Nudelman, A.; Stoltz, B. M.; Bercaw, J. E.; Goldberg, K. I. Organometallics. 2010, 29, 2176.

2. Still, W. C.; Kahn, M.; Mitra, A. J. Org. Chem. 1978, 43, 2923. 
$40 \mu \mathrm{m}$ silica gel cartridges. Unless otherwise specified, reactions were conducted with magnetic stirring under $\mathrm{N}_{2}$. THF, $\mathrm{Et}_{2} \mathrm{O}$, DMF and $\mathrm{MeCN}$ were de-aerated via a nitrogen sparge and were dried using an Innovative Technology solvent purification system. $\mathrm{CH}_{2} \mathrm{Cl}_{2}$ was dried by distillation from $\mathrm{CaH}_{2}$. Unless otherwise specified, all reagents employed in these studies were used as received from Sigma-Aldrich, AK Scientific, Combi-Blocks, and Oakwood. Ester S1 and aldehyde S10 are commercially available. Esters S2, S6, and S23; vinyl alcohol S3; and oxazolidinones $\mathbf{S 1 8}$ and $\mathbf{S 1 9}$ were synthesized in accordance with previously reported procedures. ${ }^{3,4,5}$

\section{Synthesis of Compounds}

\section{$\alpha, \beta$-Unsaturated ester 8}

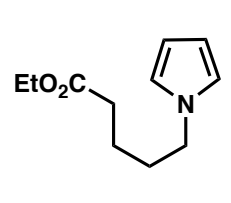

S1

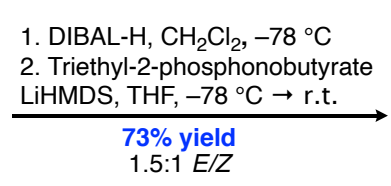

$1.5 .1 E / Z$

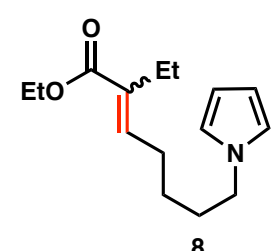

8

Flask A: LiHMDS (1.2 mL of a $1 \mathrm{M}$ solution in THF, $1.2 \mathrm{mmol}$ ) was added to a magnetically-stirred solution of triethyl-2-phosphonobutyrate $(290 \mu \mathrm{L}, 1.2 \mathrm{mmol})$ in THF $(9 \mathrm{~mL})$ maintained at $0{ }^{\circ} \mathrm{C}$. After $0.25 \mathrm{~h}$ at $0{ }^{\circ} \mathrm{C}$ the solution was cooled to $-78^{\circ} \mathrm{C}$.

Flask B: DIBAL-H (1 $\mathrm{mL}$ of a $1 \mathrm{M}$ solution in hexanes, $1 \mathrm{mmol})$ was added dropwise to a magnetically-stirred solution of ester $\mathbf{S 1}(200 \mathrm{mg}, 1.0 \mathrm{mmol})$ in $\mathrm{CH}_{2} \mathrm{Cl}_{2}(10 \mathrm{~mL})$ maintained at $78^{\circ} \mathrm{C}$. After $1 \mathrm{~h}$ at $-78^{\circ} \mathrm{C}$, the contents of flask $\mathrm{A}$ were transferred to flask $\mathrm{B}$ via syringe and the resulting solution was maintained at $-78{ }^{\circ} \mathrm{C}$ for $0.5 \mathrm{~h}$, then was allowed to warm to r.t. and was maintained at this temperature for $0.5 \mathrm{~h}$. The reaction was quenched with $\mathrm{H}_{2} \mathrm{O}(30 \mathrm{~mL})$ then $\mathrm{Et}_{2} \mathrm{O}$ $\left(30 \mathrm{~mL}\right.$ ) was added followed by $\mathrm{KHSO}_{4}$ (saturated aqueous solution) until complete dissolution of insoluble salts was achieved. The $\mathrm{Et}_{2} \mathrm{O}$ phase was collected and the aqueous phase was extracted with $\mathrm{Et}_{2} \mathrm{O}(2 \times 20 \mathrm{~mL})$. The combined $\mathrm{Et}_{2} \mathrm{O}$ extracts were dried $\left(\mathrm{MgSO}_{4}\right)$, filtered and concentrated to yield a colorless oil $(200 \mathrm{mg})$. The residue was subjected to flash column chromatography (silica; 10\% EtOAc/hexanes) to provide previously unreported, chromatographically-inseparable $\alpha, \beta$-unsaturated esters 8 (186 mg, 73\% yield, 1.5:1 E/Z) as a colorless oil. The ${ }^{1} \mathrm{H}$ and ${ }^{13} \mathrm{C}$ NMR spectra for compounds 8 are provided on pages S-45-47. HRMS (ESI): $\mathrm{m} / \mathrm{z}$ calcd for $\mathrm{C}_{15} \mathrm{H}_{23} \mathrm{NO}_{2} \mathrm{Na} 272.1621$; found 272.1616.

\section{$\alpha, \beta$-Unsaturated ester 15}
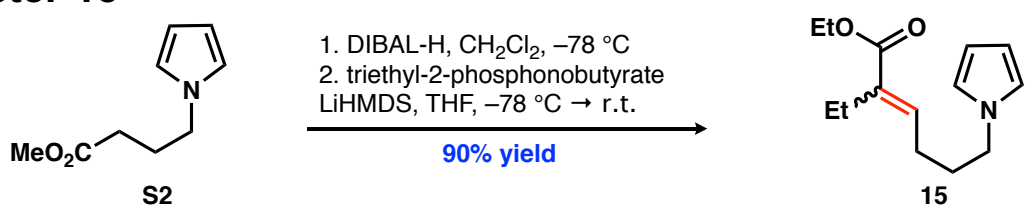

Flask A: LiHMDS (3.2 $\mathrm{mL}$ of a $1 \mathrm{M}$ solution in THF, $3.2 \mathrm{mmol}$ ) was added dropwise to a magnetically-stirred solution of triethyl-2-phosphonobutyrate $(790 \mu \mathrm{L}, 3.3 \mathrm{mmol})$ in THF $(15 \mathrm{~mL})$ maintained at $0{ }^{\circ} \mathrm{C}$. After $0.25 \mathrm{~h}$ at $0{ }^{\circ} \mathrm{C}$ the solution was cooled to $-78{ }^{\circ} \mathrm{C}$.

3. Olivier, W. J.; Gardiner, M. G.; Bissember, A. C.; Smith, J. A. Tetrahedron 2018, 74, 5436.

4. Olivier, W. J.; Lucas, N. T.; Bissember, A. C.; Smith, J. A. Chem. - Eur. J. 2021, 27,

doi:10.1002/chem.202102651

5. Olivier, W. J.; Bissember, A. C.; Smith, J. A. Org. Lett. 2021, 23, 3437. 
Flask B: DIBAL-H (2.5 mL of a $1 \mathrm{M}$ solution in cyclohexane) was added dropwise to a magnetically-stirred solution of ester $\mathbf{S 2}(425 \mathrm{mg}, 2.54 \mathrm{mmol})$ in $\mathrm{CH}_{2} \mathrm{Cl}_{2}(20 \mathrm{~mL})$ maintained at $78^{\circ} \mathrm{C}$. After $1 \mathrm{~h}$ at $-78^{\circ} \mathrm{C}$, the contents of flask A were transferred to flask $\mathrm{B}$ via cannula and the ensuing solution was maintained at $-78^{\circ} \mathrm{C}$ for $0.33 \mathrm{~h}$, after which time the solution was allowed to warm to r.t. After $18 \mathrm{~h}, \mathrm{NH}_{4} \mathrm{Cl}$ (20 mL of a saturated aqueous solution), $\mathrm{Et}_{2} \mathrm{O}(50 \mathrm{~mL})$ and $\mathrm{KHSO}_{4}$ (saturated aqueous solution) were added successively to promote dissolution of insoluble salts. The $\mathrm{Et}_{2} \mathrm{O}$ phase was collected and the aqueous phase was further extracted with $\mathrm{Et}_{2} \mathrm{O}(2 \mathrm{x}$ $30 \mathrm{~mL})$. The combined $\mathrm{Et}_{2} \mathrm{O}$ extracts were dried $\left(\mathrm{Na}_{2} \mathrm{SO}_{4}\right)$, filtered and concentrated to provide a yellow oil $(0.9 \mathrm{~g})$. The residue was subjected to flash column chromatography (silica; $10 \%$ EtOAc/hexanes) to provide a 1.4:1 mixture of esters $\boldsymbol{E}-15$ and Z-15 (539 mg, $2.29 \mathrm{mmol}, 90 \%$ yield) as colorless oils. A sample of previously unreported ester $\boldsymbol{E}-15$ was partially-seperable by flash column chromatography.

E-15: ${ }^{1} \mathrm{H}$ NMR $\left(600 \mathrm{MHz}\right.$, acetone- $\left.d_{6}\right): \delta 6.71(\mathrm{t}, J=2.1 \mathrm{~Hz}, 2 \mathrm{H}), 6.68(\mathrm{t}, J=7.5 \mathrm{~Hz}, 1 \mathrm{H}), 6.01(\mathrm{t}$, $J=7.1 \mathrm{~Hz}, 2 \mathrm{H}), 4.14(\mathrm{q}, J=7.1 \mathrm{~Hz}, 2 \mathrm{H}), 3.97(\mathrm{t}, J=6.9 \mathrm{~Hz}, 2 \mathrm{H}), 2.26(\mathrm{q}, J=7.5 \mathrm{~Hz}, 2 \mathrm{H}), 2.17$ (q, $J=7.6 \mathrm{~Hz}, 2 \mathrm{H}$ ), 1.91 (quint, $J=7.1 \mathrm{~Hz}, 2 \mathrm{H}$ ), 1.25 (t, $J=7.1 \mathrm{~Hz}, 3 \mathrm{H}$ ), 0.94 (t, $J=7.5 \mathrm{~Hz}, 3 \mathrm{H}$ ) ppm.

${ }^{13} \mathrm{C}$ NMR $\left(150 \mathrm{MHz}\right.$, acetone- $\left.d_{6}\right): \delta 167.7,141.0,135.6,121.1,108.5,60.7,49.4,31.6,26.0,20.6$, 14.6, $14.2 \mathrm{ppm}$.

IR (KBr): 1709, $1243 \mathrm{~cm}^{-1}$.

HRMS (ESI): $m / z$ calcd for $\mathrm{C}_{14} \mathrm{H}_{21} \mathrm{NO}_{2} \mathrm{Na}[\mathrm{M}+\mathrm{Na}]^{+} 258.1465$; found 258.1465.

The ${ }^{1} \mathrm{H}$ and ${ }^{13} \mathrm{C}$ NMR spectra of the mixture of $E-15$ and $Z-15$ are provided on pages S-51-53.

\section{Hydroxyester S4}

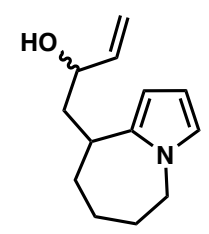

(土)-S3

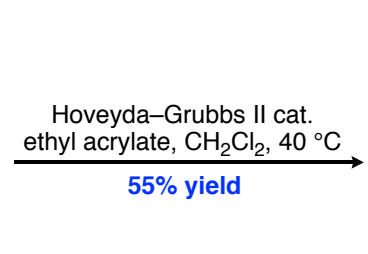

$55 \%$ yield

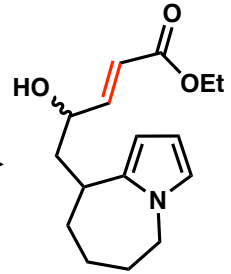

(土)-S4

Ethyl acrylate $(180 \mu \mathrm{L}, 1.7 \mathrm{mmol})$ and Hoveyda-Grubbs II catalyst (45 mg, $0.07 \mathrm{mmol})$ were added to a magnetically-stirred solution of vinyl alcohols $\mathbf{S 3}(182 \mathrm{mg}, 0.89 \mathrm{mmol})$ in $\mathrm{CH}_{2} \mathrm{Cl}_{2}(7$ $\mathrm{mL}$ ) and the ensuing solution was heated at reflux (Al block). After $18 \mathrm{~h}$, the solution was cooled to r.t. and quenched with ethyl vinyl ether $(0.4 \mathrm{~mL})$. The resulting solution was concentrated and the residue was subjected to flash column chromatography (silica; $32 \% \mathrm{EtOAc/hexanes)} \mathrm{to}$ provide previously reported chromatographically-inseparable diastereomers S4 (136 mg, 0.49 mmol, $55 \%$ yield) as a colorless oil. ${ }^{4}$

\section{Ketoester 22}

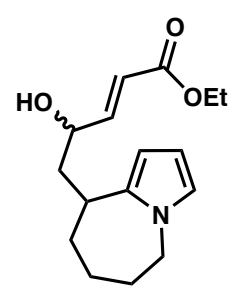

(土)-S4
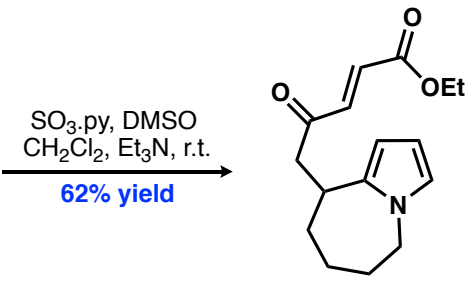

(士)-22

Sulfur trioxide pyridine complex $(718 \mathrm{mg}, 4.51 \mathrm{mmol})$ was dissolved in DMSO $(3 \mathrm{~mL})$ and the solution was magnetically-stirred for 10 min at r.t. before the addition of $\mathrm{CH}_{2} \mathrm{Cl}_{2}(5 \mathrm{~mL}), \mathrm{Et}{ }_{3} \mathrm{~N}(1.3$ $\mathrm{mL}, 9.3 \mathrm{mmol}$ ) and a solution of alcohol $\mathbf{S} 4(125 \mathrm{mg}, 0.45 \mathrm{mmol})$ in $\mathrm{CH}_{2} \mathrm{Cl}_{2}(3 \mathrm{~mL})$ successive. The ensuing solution was maintained at r.t. After $4.5 \mathrm{~h}, \mathrm{NaHCO}_{3}(10 \mathrm{~mL}$ of a saturated aqueous solution) and $\mathrm{H}_{2} \mathrm{O}(10 \mathrm{~mL})$ were added successively. The resulting mixture was extracted with 
$\mathrm{Et}_{2} \mathrm{O}(1 \times 10 \mathrm{~mL}$ and $2 \times 30 \mathrm{~mL})$ and the combined $\mathrm{Et}_{2} \mathrm{O}$ extracts were washed with $\mathrm{H}_{2} \mathrm{O}(3 \times 10$ $\mathrm{mL})$, brine $(1 \times 10 \mathrm{~mL})$, dried $\left(\mathrm{MgSO}_{4}\right)$, filtered and concentrated to yield a light-brown solid (130 $\mathrm{mg}$ ). The residue was subjected to flash column chromatography (silica; $10 \%$ EtOAc/hexanes + $2 \% \mathrm{Et}_{3} \mathrm{~N}$ ) to provide previously unreported ketone 22 as a colorless, amorphous solid (77 mg, $0.28 \mathrm{mmol}, 62 \%$ yield).

${ }^{1} \mathrm{H}$ NMR $\left(600 \mathrm{MHz}\right.$, acetone- $\left.d_{6}\right): \delta 7.09(\mathrm{~d}, J=16.0 \mathrm{~Hz}, 1 \mathrm{H}), 6.74(\mathrm{~d}, J=16.0 \mathrm{~Hz}, 1 \mathrm{H}), 6.52(\mathrm{~m}$, $1 \mathrm{H}), 5.79(\mathrm{t}, J=3.2 \mathrm{~Hz}, 1 \mathrm{H}), 5.76(\mathrm{~m}, 1 \mathrm{H}), 4.24(\mathrm{q}, J=7.1 \mathrm{~Hz}, 2 \mathrm{H}), 4.08(\mathrm{dd}, J=14.3,6.2 \mathrm{~Hz}$, $1 \mathrm{H}), 3.93$ (dd, $J=13.6,11.1 \mathrm{~Hz}, 1 \mathrm{H}), 3.34-3.25(\mathrm{~m}, 2 \mathrm{H}), 3.03(\mathrm{dd}, J=17.1,7.9 \mathrm{~Hz}, 1 \mathrm{H}), 1.96-$ $1.87(\mathrm{~m}, 2 \mathrm{H}), 1.78(\mathrm{~m}, 1 \mathrm{H}), 1.72(\mathrm{~m}, 1 \mathrm{H}), 1.43(\mathrm{~m}, 1 \mathrm{H}), 1.29(\mathrm{t}, J=7.1 \mathrm{~Hz}, 3 \mathrm{H}) \mathrm{ppm}$.

${ }^{13} \mathrm{C}$ NMR $\left(150 \mathrm{MHz}\right.$, acetone- $\left.d_{6}\right): \delta 199.1,166.1,140.6,137.6,131.2,122.2,106.1,105.4,61.8$, 50.1, 45.9, 35.4, 34.3, 30.6, 30.3, 14.4 ppm.

IR (KBr): 1722, $1699 \mathrm{~cm}^{-1}$.

HRMS (ESI): $m / z$ calcd for $\mathrm{C}_{16} \mathrm{H}_{21} \mathrm{NO}_{3} \mathrm{Na}[\mathrm{M}+\mathrm{Na}]^{+} 298.1414$; found 298.1407.

\section{Tricyclic pyrrole 23}

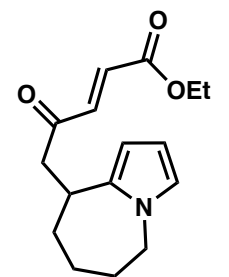

$( \pm)-22$

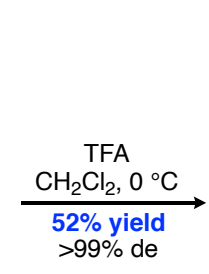

$>99 \%$ de

TFA (15 $\mu \mathrm{L}, 0.2 \mathrm{mmol})$ was added to a magnetically-stirred solution of $\alpha, \beta$-unsaturated ketone 22 (21 mg, $0.076 \mathrm{mmol})$ in $\mathrm{CH}_{2} \mathrm{Cl}_{2}(7 \mathrm{~mL})$ maintained at $0{ }^{\circ} \mathrm{C}$. After $0.67 \mathrm{~h}$ at $0{ }^{\circ} \mathrm{C}$, the reaction was quenched with $\mathrm{NaHCO}_{3}(5 \mathrm{~mL})$ and the organic phase was collected. The resulting aqueous phase was extracted with $\mathrm{CH}_{2} \mathrm{Cl}_{2}(2 \times 5 \mathrm{~mL})$, dried $\left(\mathrm{MgSO}_{4}\right)$, filtered, and concentrated to provide a colorless oil $(18 \mathrm{mg})$. The ${ }^{1} \mathrm{H}$ NMR spectrum of the crude residue revealed tricycle 23 to be the sole product. The crude residue was subjected to flash column chromatography (silica; $30 \%$ EtOAc/hexanes) to provide previously unreported compound 23 as a colorless oil (11 mg, 0.040 $\mathrm{mmol}, 52 \%$ yield).

${ }^{1} \mathrm{H}$ NMR $\left(600 \mathrm{MHz}\right.$, acetone- $\left.d_{6}\right): \delta 6.48(\mathrm{~d}, J=2.7 \mathrm{~Hz}, 1 \mathrm{H}), 5.72(\mathrm{~d}, J=2.7 \mathrm{~Hz}, 1 \mathrm{H}), 4.21-4.13$ (m, 3H), 4.02 (ddt, $J=14.4,5.2,3.4 \mathrm{~Hz}, 1 \mathrm{H}), 3.84(\mathrm{dd}, J=14.2,11.3 \mathrm{~Hz}, 1 \mathrm{H}), 3.00(\mathrm{~m}, 1 \mathrm{H}), 2.91$ (dd, $J=12.1,8.8 \mathrm{~Hz}, 1 \mathrm{H}), 2.86-2.82(\mathrm{~m}, 2 \mathrm{H}), 2.70(\mathrm{dd}, J=17.8,4.3 \mathrm{~Hz}, 1 \mathrm{H}), 1.98-1.93(\mathrm{~m}, 2 \mathrm{H})$, $1.81(\mathrm{~m}, 1 \mathrm{H}), 1.65(\mathrm{~m}, 1 \mathrm{H}), 1.36-1.28(\mathrm{~m}, 2 \mathrm{H}), 1.24(\mathrm{t}, J=7.1 \mathrm{~Hz}, 3 \mathrm{H}) \mathrm{ppm}$.

${ }^{13} \mathrm{C}$ NMR $\left(150 \mathrm{MHz}\right.$, acetone- $\left.d_{6}\right): \delta 209.4,174.1,132.2,120.6,118.0,107.7,61.2,50.1,47.7$, 47.5, 40.6, 37.0, 36.0, 30.4, 30.1, $14.5 \mathrm{ppm}$.

IR (KBr): 1729, $1705 \mathrm{~cm}^{-1}$.

HRMS (ESI): $m / z$ calcd for $\mathrm{C}_{16} \mathrm{H}_{21} \mathrm{NO}_{3} \mathrm{Na}[\mathrm{M}+\mathrm{Na}]^{+} 298.1414$; found 298.1414.

\section{Alcohol S5}

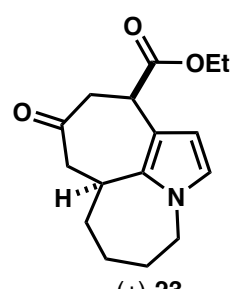

$( \pm)-23$

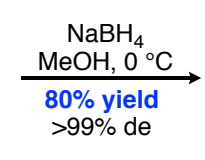

$>99 \%$ de

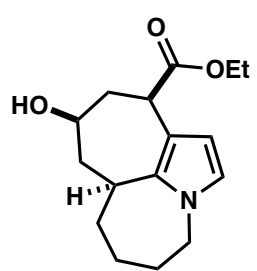

$( \pm)-\mathrm{S} 5$

$\mathrm{NaBH}_{4}(5 \mathrm{mg}, 0.1 \mathrm{mmol})$ was added to a magnetically-stirred solution of ketone 23 (10 mg, 0.036 $\mathrm{mmol})$ in $\mathrm{MeOH}(1.5 \mathrm{~mL})$ maintained at $0{ }^{\circ} \mathrm{C}$. After $1 \mathrm{~h}$ at $0{ }^{\circ} \mathrm{C}$, the reaction was quenched with $\mathrm{NH}_{4} \mathrm{Cl}$ (5 $\mathrm{mL}$ of a saturated aqueous solution) and the aqueous phase was extracted with $\mathrm{CH}_{2} \mathrm{Cl}_{2}$ $(3 \times 5 \mathrm{~mL})$. The combined $\mathrm{CH}_{2} \mathrm{Cl}_{2}$ extracts were dried $\left(\mathrm{MgSO}_{4}\right)$, filtered and concentrated to yield 
a colorless oil (9 mg). The residue was subjected to flash column chromatography (silica; $25 \%$ EtOAc/hexanes $+2 \% \mathrm{Et}_{3} \mathrm{~N}$ ) to provide previously unreported alcohol $\mathbf{S 5}$ as a colorless oil (8 $\mathrm{mg}$, $0.029 \mathrm{mmol}, 80 \%$ yield).

${ }^{1} \mathrm{H}$ NMR $\left(600 \mathrm{MHz}\right.$, acetone- $\left.d_{6}\right): \delta 6.39(\mathrm{~d}, J=2.7 \mathrm{~Hz}, 1 \mathrm{H}), 5.64(\mathrm{~d}, J=2.7 \mathrm{~Hz}, 1 \mathrm{H}), 4.14(\mathrm{q}, J=$ $7.1 \mathrm{~Hz}, 2 \mathrm{H}), 4.06(\mathrm{~m}, 1 \mathrm{H}), 3.97(\mathrm{~m}, 1 \mathrm{H}), 3.84(\mathrm{dd}, J=14.0,11.1, \mathrm{~Hz}, 1 \mathrm{H}), 3.72(\mathrm{~d}, J=6.0 \mathrm{~Hz}$, $1 \mathrm{H}$ ), 3.68 (dd, $J=9.1,3.1 \mathrm{~Hz}, 1 \mathrm{H}$ ), 3.01 (quint, $J=5.2 \mathrm{~Hz}, 1 \mathrm{H}$ ), 2.28 (ddd, $J=14.2,6.1,3.1 \mathrm{~Hz}$, $1 \mathrm{H}), 2.12-2.07(\mathrm{~m}, 3 \mathrm{H}), 1.94-1.89(\mathrm{~m}, 2 \mathrm{H}), 1.79(\mathrm{~m}, 1 \mathrm{H}), 1.62(\mathrm{~m}, 1 \mathrm{H}), 1.41-1.26(\mathrm{~m}, 2 \mathrm{H}), 1.24$ $(\mathrm{t}, J=7.1 \mathrm{~Hz}, 3 \mathrm{H}) \mathrm{ppm}$.

${ }^{13} \mathrm{C}$ NMR $\left(150 \mathrm{MHz}\right.$, acetone- $\left.d_{6}\right): \delta 175.9,134.8,120.0,118.9,107.6,68.0,60.8,49.9,42.8,42.3$, $41.5,35.6,35.2,30.5,30.2$ (overlapping with residual solvent signal), $14.5 \mathrm{ppm}$.

IR (KBr): $3417,1733 \mathrm{~cm}^{-1}$.

HRMS (ESI): $m / z$ calcd for $\mathrm{C}_{16} \mathrm{H}_{24} \mathrm{NO}_{3}[\mathrm{M}+\mathrm{H}]^{+} 278.1751$; found 278.1745.

\section{Vinyl ketone S8}

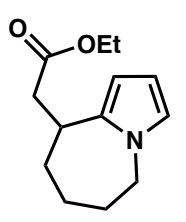

(土)-S6

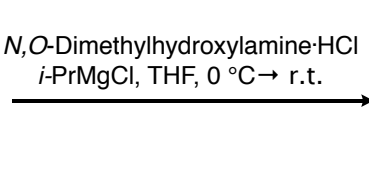

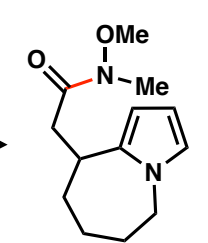

$( \pm)-S 7$

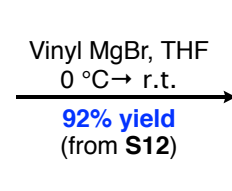
Step i. N,O-Dimethylhydroxylamine hydrochloride $(30 \mathrm{mg}, 0.31 \mathrm{mmol})$ and $i-\mathrm{PrMgCl}(0.37 \mathrm{~mL}$ of a $\sim 2 \mathrm{M}$ solution in THF, $0.74 \mathrm{mmol}$ ) were added to a magnetically-stirred solution of ester $\mathbf{S 6}$ (54 $\mathrm{mg}, 0.24 \mathrm{mmol})$ in THF $(5 \mathrm{~mL})$ maintained at $0{ }^{\circ} \mathrm{C}$. After $1 \mathrm{~h}$ at $0{ }^{\circ} \mathrm{C}$, further $i-\operatorname{PrMgCl}(0.2 \mathrm{~mL}$ of a $2 \mathrm{M}$ solution in THF, $0.4 \mathrm{mmol}$ ) was added and the solution was maintained at $0{ }^{\circ} \mathrm{C}$ for $2 \mathrm{~h}$ then was allowed to warm to r.t. and was maintained at this temperature for $18 \mathrm{~h}$. After this time, the solution was cooled to $0{ }^{\circ} \mathrm{C}$ and the reaction was quenched with $\mathrm{NH}_{4} \mathrm{Cl}(3 \mathrm{~mL}$ of a saturated aqueous solution). $\mathrm{H}_{2} \mathrm{O}(3 \mathrm{~mL})$ and $\mathrm{KHSO}_{4}(1 \mathrm{~mL}$ of a saturated aqueous solution) were added and the aqueous phase was extracted with $\mathrm{Et}_{2} \mathrm{O}(3 \times 5 \mathrm{~mL})$. The combined $\mathrm{Et}_{2} \mathrm{O}$ extracts were dried $\left(\mathrm{MgSO}_{4}\right)$, filtered, and concentrated to provide a residue, which was filtered through a plug of silica (EtOAc) to provide the crude Weinreb amide $\mathbf{S 7}(50 \mathrm{mg})$. Compound $\mathbf{S 7}$ was not isolated but was immediately subjected to the next step described immediately below.

Step ii. Vinylmagnesium bromide (1.2 mL of a $1 \mathrm{M}$ solution in THF, $1.2 \mathrm{mmol}$ ) was added dropwise to a magnetically-stirred solution of Weinreb amide $\mathbf{S 7}(50 \mathrm{mg})$ in $\mathrm{Et}_{2} \mathrm{O}(3 \mathrm{~mL})$ maintained $0{ }^{\circ} \mathrm{C}$. The solution was allowed to warm to r.t. and was maintained at this temperature. After $18 \mathrm{~h}$, the solution was cooled to $0{ }^{\circ} \mathrm{C}$ and the reaction was quenched with $\mathrm{NH}_{4} \mathrm{Cl}(3 \mathrm{~mL}$ of a saturated aqueous solution). $\mathrm{H}_{2} \mathrm{O}(3 \mathrm{~mL})$ and $\mathrm{KHSO}_{4}(1 \mathrm{~mL}$ of a saturated aqueous solution) were added and the aqueous phase was extracted with $\mathrm{Et}_{2} \mathrm{O}(3 \times 5 \mathrm{~mL})$. The combined $\mathrm{Et}_{2} \mathrm{O}$ extracts were dried $\left(\mathrm{MgSO}_{4}\right)$, filtered, and concentrated to provide a residue which was eluted through a plug of silica $\left(10 \% \mathrm{EtOAc} /\right.$ hexanes $\left.+1 \% \mathrm{Et}_{3} \mathrm{~N}\right)$ to provide previously unreported ketone $\mathbf{S 8}$ as a colorless amorphous solid ( $45 \mathrm{mg}, 0.22 \mathrm{mmol}, 92 \%$ yield over 2 steps).

${ }^{1} \mathrm{H}$ NMR $\left(600 \mathrm{MHz}\right.$, acetone- $\left.d_{6}\right): \delta 6.52(\mathrm{t}, J=2.2 \mathrm{~Hz}, 1 \mathrm{H}), 6.45(\mathrm{dd}, J=17.6,10.6 \mathrm{~Hz}, 1 \mathrm{H}), 6.32$ (dd, $J=17.5,0.7 \mathrm{~Hz}, 1 \mathrm{H}), 5.87(\mathrm{dd}, J=10.6,1.0 \mathrm{~Hz}, 1 \mathrm{H}), 5.79(\mathrm{t}, J=3.4 \mathrm{~Hz}, 1 \mathrm{H}), 5.73(\mathrm{~m}, 1 \mathrm{H})$, $4.07(\mathrm{br} \mathrm{dd}, J=14.2,6.1 \mathrm{~Hz}, 1 \mathrm{H}), 3.91(\mathrm{dd}, J=13.9,11.1 \mathrm{~Hz}, 1 \mathrm{H}), 3.29(\mathrm{~m}, 1 \mathrm{H}), 3.13(\mathrm{dd}, J=$ 16.8, $5.9 \mathrm{~Hz}, 1 \mathrm{H}), 2.89(\mathrm{dd}, J=16.8,8.3 \mathrm{~Hz}, 1 \mathrm{H}), 1.97-1.87(\mathrm{~m}, 2 \mathrm{H}), 1.76(\mathrm{~m}, 1 \mathrm{H}), 1.70(\mathrm{~m}, 1 \mathrm{H})$, $1.42(\mathrm{~m}, 1 \mathrm{H}), 1.22(\mathrm{~m}, 1 \mathrm{H}) \mathrm{ppm}$.

${ }^{13} \mathrm{C}$ NMR $\left(150 \mathrm{MHz}\right.$, acetone- $\left.d_{6}\right): \delta 199.3,137.9,137.8,128.2,122.1,106.1,105.2,50.1,44.3$, 35.4, 34.4, 30.6 ppm.

IR $(\mathrm{NaCl}): 1682 \mathrm{~cm}^{-1}$.

HRMS (ESI): $\mathrm{m} / \mathrm{z}$ calcd for $\mathrm{C}_{13} \mathrm{H}_{17} \mathrm{NONa}[\mathrm{M}+\mathrm{Na}]^{+} 226.1202$; found 226.1201. 


\section{Tricyclic pyrrole S9}

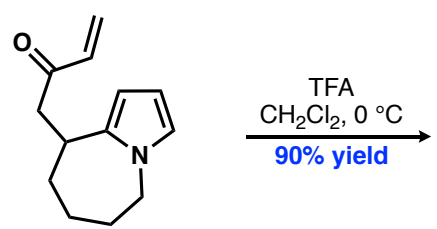

(土)-S8

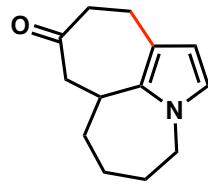

$( \pm)$-S9

A solution of $\alpha, \beta$-unsaturated ketone $\mathbf{S 8}(10 \mathrm{mg}, 0.049 \mathrm{mmol})$ in $\mathrm{CH}_{2} \mathrm{Cl}_{2}(2 \mathrm{~mL})$ was added dropwise over $1.5 \mathrm{~h}$ to a magnetically-stirred solution of trifluoroacetic acid $(11 \mathrm{mg}, 0.10 \mathrm{mmol})$ in $\mathrm{CH}_{2} \mathrm{Cl}_{2}(2.6 \mathrm{~mL})$ maintained at $0{ }^{\circ} \mathrm{C}$. Upon completion of the addition, $\mathrm{NaHCO}_{3}(5 \mathrm{~mL}$ of a saturated aqueous solution) was added and the aqueous phase was extracted with $\mathrm{CH}_{2} \mathrm{Cl}_{2}(3 \mathrm{x}$ $5 \mathrm{~mL}$ ). The combined $\mathrm{CH}_{2} \mathrm{Cl}_{2}$ extracts were dried $\left(\mathrm{MgSO}_{4}\right)$, filtered, and concentrated to yield a colorless solid (10 mg). The residue was subjected to flash column chromatography (silica; $15 \%$ EtOAc/hexanes $+2 \% \mathrm{Et}_{3} \mathrm{~N}$ ) to provide previously unreported ketone $\mathbf{S 9}$ as a colorless solid (9 $\mathrm{mg}, 0.044 \mathrm{mmol}, 90 \%$ yield). The solid was recrystallized via slow evaporation from $\mathrm{Et}_{2} \mathrm{O} / \mathrm{n}$ pentane to provide colorless needles suitable for single crystal X-ray crystallography.

${ }^{1} \mathrm{H}$ NMR $\left(600 \mathrm{MHz}\right.$, acetone- $\left.d_{6}\right): \delta 6.40(\mathrm{~d}, J=2.6 \mathrm{~Hz}, 1 \mathrm{H}), 5.67(\mathrm{~d}, J=2.6 \mathrm{~Hz}, 1 \mathrm{H}), 4.00(\mathrm{~m}, 1 \mathrm{H})$, $3.78(\mathrm{dd}, J=14.2,11.9 \mathrm{~Hz}, 1 \mathrm{H}), 3.02-2.94(\mathrm{~m}, 3 \mathrm{H}), 2.78(\mathrm{~m}, 1 \mathrm{H}), 2.73(\mathrm{ddd}, J=15.4,6.6,4.6$ $\mathrm{Hz}, 1 \mathrm{H}), 2.54$ (ddd, $J=18.0,6.6,4.7 \mathrm{~Hz}, 1 \mathrm{H}), 2.47$ (ddd, $J=18.0,9.1,4.6 \mathrm{~Hz}, 1 \mathrm{H}), 1.98-1.91(\mathrm{~m}$, $2 \mathrm{H}$ ), $1.82(\mathrm{~m}, 1 \mathrm{H}), 1.63$ (qt, $J=13.2,3.2 \mathrm{~Hz}, 1 \mathrm{H}), 1.37-1.24(\mathrm{~m}, 2 \mathrm{H}) \mathrm{ppm}$.

${ }^{13} \mathrm{C}$ NMR $\left(150 \mathrm{MHz}\right.$, acetone- $\left.d_{6}\right): \delta 211.7,131.6,120.4,120.2,108.1,50.4,46.5,45.8,37.9,37.2$, 30.6, 30.3, $23.1 \mathrm{ppm}$.

IR (KBr): $1699 \mathrm{~cm}^{-1}$.

HRMS (ESI): $m / z$ calcd for $\mathrm{C}_{13} \mathrm{H}_{17} \mathrm{NONa}[\mathrm{M}+\mathrm{Na}]^{+} 226.1202$; found 226.1203.

\section{$\alpha, \beta$-Unsaturated ester S11}
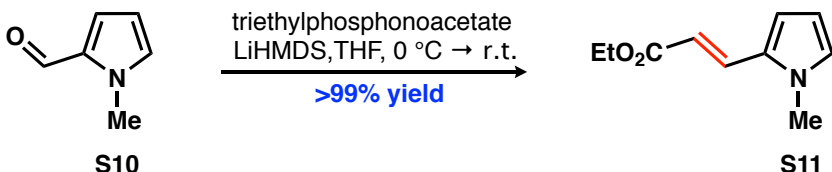

LiHMDS (17.8 $\mathrm{mL}$ of a $1 \mathrm{M}$ solution in THF, $17.8 \mathrm{mmol})$ was added in 4 portions to a magneticallystirred solution of triethylphosphonoacetate $(3.55 \mathrm{~mL}, 17.9 \mathrm{mmol})$ in THF maintained at $0{ }^{\circ} \mathrm{C}$. After $0.33 \mathrm{~h}$ at $0{ }^{\circ} \mathrm{C}$, aldehyde $\mathbf{S 1 0}(1.5 \mathrm{~mL}, 14 \mathrm{mmol})$ was added and the solution was maintained at $0{ }^{\circ} \mathrm{C}$ for 5 min then allowed to warm to r.t. After $2.5 \mathrm{~h}$, the reaction was quenched with $\mathrm{NH}_{4} \mathrm{Cl}(10$ $\mathrm{mL}$ of a saturated aqueous solution) and $\mathrm{H}_{2} \mathrm{O}(30 \mathrm{~mL})$ and the ensuing aqueous phase was extracted with $\mathrm{CH}_{2} \mathrm{Cl}_{2}(1 \times 50 \mathrm{~mL}, 2 \times 20 \mathrm{~mL})$. The combined $\mathrm{CH}_{2} \mathrm{Cl}_{2}$ extracts were washed with brine $(30 \mathrm{~mL})$, dried $\left(\mathrm{MgSO}_{4}\right)$, filtered, and concentrated to provide a light-yellow oil $(2.7 \mathrm{~g})$. The residue was eluted through a plug of silica (20\% EtOAc/hexanes) to provide previously reported ester S11 as a colorless oil $(2.53 \mathrm{~g}, 14.1 \mathrm{mmol},>99 \%$ yield $){ }^{6}$

${ }^{1} \mathrm{H}$ NMR $\left(600 \mathrm{MHz}, \mathrm{CDCl}_{3}\right): \delta 7.59(\mathrm{~d}, J=15.7 \mathrm{~Hz}, 1 \mathrm{H}), 6.74(\mathrm{t}, J=1.8 \mathrm{~Hz}, 1 \mathrm{H}), 6.65(\mathrm{dd}, J=4.0$, $1.5 \mathrm{~Hz}, 1 \mathrm{H}), 6.17-6.13(\mathrm{~m}, 2 \mathrm{H}), 4.24(\mathrm{q}, J=7.1 \mathrm{~Hz}, 2 \mathrm{H}), 3.71(\mathrm{~s}, 3 \mathrm{H}), 1.32(\mathrm{t}, J=7.1 \mathrm{~Hz}, 3 \mathrm{H})$ ppm.

${ }^{13} \mathrm{C}$ NMR $\left(150 \mathrm{MHz}, \mathrm{CDCl}_{3}\right): \delta 168.0,132.4,129.5,127.0,112.9,112.1,109.5,60.3,34.6,14.5$ ppm. 


\section{Ester S12}
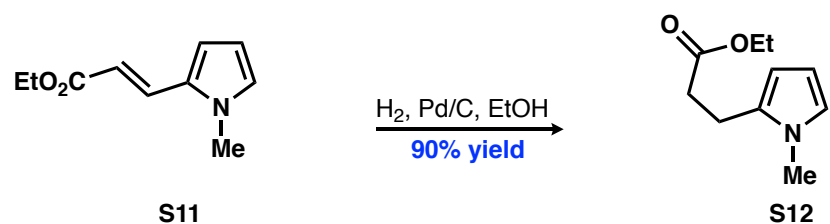

Palladium on carbon ( $298 \mathrm{mg}$ of $5 \% \mathrm{Pd} / \mathrm{C}, 0.14 \mathrm{mmol}$ ) was added to a solution of $\alpha, \beta$-unsaturated ester $\mathbf{S 1 1}(2.53 \mathrm{~g}, 14.1 \mathrm{mmol})$ in $\mathrm{EtOH}(40 \mathrm{~mL})$ and the ensuing mixture was placed under an atmosphere of $\mathrm{H}_{2}(40 \mathrm{psi})$ with shaking for $1.5 \mathrm{~h}$. The suspension was then filtered through a plug of celite and concentrated to provide a colorless oil $(\sim 2.6 \mathrm{~g})$. The residue was eluted through a plug of silica (15\% EtOAc/hexanes). Following combination of appropriate fractions, previously reported ester $\mathbf{S} 12$ was obtained as a colorless oil $(2.30 \mathrm{~g}, 12.7 \mathrm{mmol}, 90 \%$ yield $){ }^{7}$

${ }^{1} \mathrm{H}$ NMR $\left(600 \mathrm{MHz}\right.$, acetone- $\left.d_{6}\right): \delta 6.53(\mathrm{~m}, 1 \mathrm{H}), 5.87(\mathrm{~m}, 1 \mathrm{H}), 5.77(\mathrm{~m}, 1 \mathrm{H}), 4.09(\mathrm{q}, J=7.1 \mathrm{~Hz}$, 2H), $3.55(\mathrm{~s}, 3 \mathrm{H}), 2.83(\mathrm{t}, J=7.9 \mathrm{~Hz}, 2 \mathrm{H}), 2.58(\mathrm{dd}, J=7.9,6.5 \mathrm{~Hz}, 2 \mathrm{H}), 1.21(\mathrm{t}, J=7.1 \mathrm{~Hz}, 3 \mathrm{H})$ ppm.

${ }^{13} \mathrm{C}$ NMR $\left(150 \mathrm{MHz}\right.$, acetone- $\left.d_{6}\right): \delta 173.0,132.1,122.0,107.1,106.2,60.7,34.2,33.5,22.1,14.6$ ppm.

IR (KBr): $1735 \mathrm{~cm}^{-1}$.

HRMS (ESI): $m / z$ calcd for $\mathrm{C}_{10} \mathrm{H}_{15} \mathrm{NO}_{2} \mathrm{Na}[\mathrm{M}+\mathrm{Na}]^{+} 204.0995$; found 204.0991.

\section{Vinyl alcohol S13}
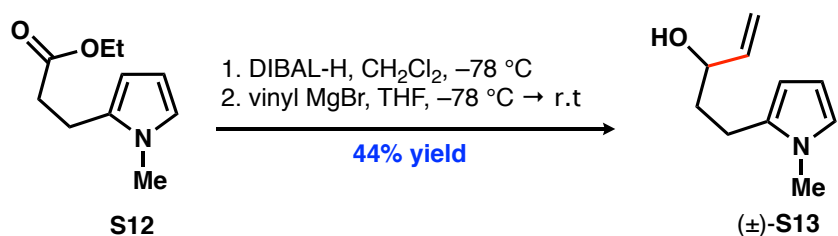

DIBAL-H (5.6 mL of a $1 \mathrm{M}$ solution in cyclohexane, $5.6 \mathrm{mmol}$ ) was added dropwise to a magnetically-stirred solution of ester $\mathbf{S} 12(1.02 \mathrm{~g}, 5.6 \mathrm{mmol})$ in $\mathrm{CH}_{2} \mathrm{Cl}_{2}(35 \mathrm{~mL})$ maintained at -78 ${ }^{\circ} \mathrm{C}$. After $1 \mathrm{~h}$, vinylmagnesium bromide $(11 \mathrm{~mL}$ of a $1 \mathrm{M}$ solution in THF, $11 \mathrm{mmol})$ was added dropwise and the resulting solution was maintained at $-78^{\circ} \mathrm{C}$ for $0.33 \mathrm{~h}$. The solution was allowed to warm to r.t. before the addition of $\mathrm{NH}_{4} \mathrm{Cl}$ (20 mL of a saturated aqueous solution), $\mathrm{H}_{2} \mathrm{O}(20 \mathrm{~mL})$ and $\mathrm{Et}_{2} \mathrm{O}(40 \mathrm{~mL}) . \mathrm{KHSO}_{4}$ (saturated aqueous solution) was added until dissolution of insoluble salts was achieved; then the organic phase was collected and the aqueous phase was further extracted with $\mathrm{Et}_{2} \mathrm{O}(2 \times 30 \mathrm{~mL})$. The combined $\mathrm{Et}_{2} \mathrm{O}$ extracts were washed with brine $(30 \mathrm{~mL})$, dried $\left(\mathrm{MgSO}_{4}\right)$, filtered, and concentrated to yield a colorless oil $(1 \mathrm{~g})$. Half of the crude residue $(500 \mathrm{mg}$ ) was subjected to automated flash chromatography (silica; $0 \rightarrow 50 \%$ EtOAc/hexanes) to provide previously unreported vinyl alcohol $\mathbf{S 1 3}$ as a colorless oil (410 mg, $2.48 \mathrm{mmol}, 44 \%$ yield). ${ }^{1} \mathrm{H}$ NMR $\left(400 \mathrm{MHz}\right.$, acetone- $\left.d_{6}\right): \delta 6.51(\mathrm{~m}, 1 \mathrm{H}), 5.96-5.87(\mathrm{~m}, 2 \mathrm{H}), 5.76(\mathrm{~m}, 1 \mathrm{H}), 5.22(\mathrm{dt}, J=$ 17.2, $2.6 \mathrm{~Hz}, 1 \mathrm{H}), 5.03$ (ddd, 10.5, 2.7, $1.5 \mathrm{~Hz}, 1 \mathrm{H}), 4.13(\mathrm{~m}, 1 \mathrm{H}), 3.81(\mathrm{~d}, J=4.8 \mathrm{~Hz}, 1 \mathrm{H}), 3.52$ (s, 3H), $2.63(\mathrm{~m}, 2 \mathrm{H}), 1.82-1.69(\mathrm{~m}, 2 \mathrm{H}) \mathrm{ppm}$.

${ }^{1} \mathrm{H}$ NMR $\left(100 \mathrm{MHz}\right.$, acetone- $\left.d_{6}\right): \delta$ 143.2, 133.5, 121.6, 113.6, 107.0, 106.1, 72.2, 37.6, 33.5, 22.7 ppm.

IR (KBr): 3389, 1493, $1298 \mathrm{~cm}^{-1}$.

HRMS (ESI): $m / z$ calcd for $\mathrm{C}_{10} \mathrm{H}_{16} \mathrm{NO}[\mathrm{M}+\mathrm{H}]^{+}$166.1226; found 166.1227. 
Hydroxyester S14
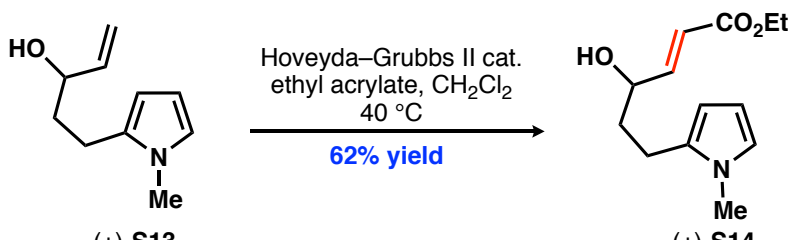

$( \pm)-\mathrm{S} 13$

$( \pm)-\mathrm{S} 14$

Ethyl acrylate $(245 \mu \mathrm{L}, 2.25 \mathrm{mmol})$ and Hoveyda-Grubbs II catalyst (53 $\mathrm{mg}, 0.085 \mathrm{mmol})$ were added to a magnetically-stirred solution of vinyl alcohol $\mathbf{S 1 3}(184 \mathrm{mg}, 1.11 \mathrm{mmol})$ in $\mathrm{CH}_{2} \mathrm{Cl}_{2}$ and the resulting solution was heated at reflux (Al block). After $16 \mathrm{~h}$, the reaction was quenched with ethyl vinyl ether $(0.5 \mathrm{~mL})$ and the resulting solution was concentrated and subjected to flash column chromatography (silica; $40 \%$ EtOAc/hexanes) to provide previously unreported hydroxyester $\mathbf{S 1 4}$ (163 $\mathrm{mg}, 0.687 \mathrm{mmol}, 62 \%$ yield) as a colorless oil.

${ }^{1} \mathrm{H}$ NMR $\left(600 \mathrm{MHz}\right.$, acetone- $\left.d_{6}\right): \delta 6.98(\mathrm{dd}, J=15.6,4.6 \mathrm{~Hz}, 1 \mathrm{H}), 6.52(\mathrm{~m}, 1 \mathrm{H}), 6.05(\mathrm{dd}, J=$ 15.6, 1,7 Hz, 1H), $5.88(\mathrm{~m}, 1 \mathrm{H}), 5.79(\mathrm{~m}, 1 \mathrm{H}), 4.37(\mathrm{~m}, 1 \mathrm{H}), 4.26(\mathrm{~d}, J=5.0 \mathrm{~Hz}, 1 \mathrm{H}), 4.15(\mathrm{q}, J=$ $7.3 \mathrm{~Hz}, 2 \mathrm{H}), 3.53(\mathrm{~s}, 3 \mathrm{H}), 2.68(\mathrm{~m}, 2 \mathrm{H}), 1.89(\mathrm{~m}, 1 \mathrm{H}), 1.77(\mathrm{~m}, 1 \mathrm{H}), 1.25(\mathrm{t}, J=7.1 \mathrm{~Hz}, 3 \mathrm{H}) \mathrm{ppm}$. ${ }^{13} \mathrm{C}$ NMR $\left(150 \mathrm{MHz}\right.$, acetone- $\left.d_{6}\right): \delta 166.8,152.2,133.0,121.8,120.3,107.1,106.3,70.3,60.6$, 36.8, 33.5, 22.6, $14.6 \mathrm{ppm}$.

IR (KBr): 1716, $1302,1274 \mathrm{~cm}^{-1}$.

HRMS (ESI): $m / z$ calcd for $\mathrm{C}_{13} \mathrm{H}_{20} \mathrm{NO}_{3}[\mathrm{M}+\mathrm{H}]^{+}$238.1438; found 238.1438.

\section{$\alpha, \beta$-Unsaturated ketoester 24}

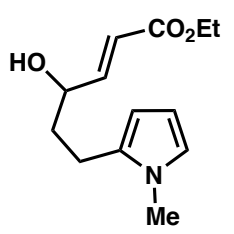

( \pm -S14

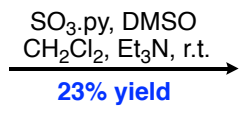

$23 \%$ yield

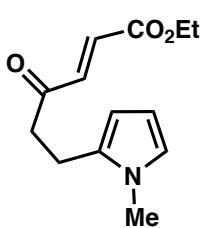

24

Sulfur trioxide pyridine complex $(1.10 \mathrm{~g}, 6.9 \mathrm{mmol})$ was dissolved in DMSO $(3.8 \mathrm{~mL})$ and magnetically-stirred for 10 min before the addition of $\mathrm{CH}_{2} \mathrm{Cl}_{2}(6 \mathrm{~mL}), \mathrm{Et}_{3} \mathrm{~N}(1.92 \mathrm{~mL}, 13.8 \mathrm{mmol})$ and a solution of alcohol $\mathbf{S 1 4}(163 \mathrm{mg}, 0.687 \mathrm{mmol})$ in $\mathrm{CH}_{2} \mathrm{Cl}_{2}(3 \mathrm{~mL})$ successively. The resulting solution was maintained at r.t. After $4.5 \mathrm{~h}, \mathrm{NaHCO}_{3}(10 \mathrm{~mL})$ and $\mathrm{H}_{2} \mathrm{O}(10 \mathrm{~mL})$ were added successively. The ensuing mixture was extracted with $\mathrm{Et}_{2} \mathrm{O}(3 \times 20 \mathrm{~mL})$ and the combined $\mathrm{Et}_{2} \mathrm{O}$ extracts were washed with $\mathrm{H}_{2} \mathrm{O}(3 \times 20 \mathrm{~mL})$ and brine $(1 \times 20 \mathrm{~mL})$, dried $\left(\mathrm{Na}_{2} \mathrm{SO}_{4}\right)$, filtered and concentrated to provide a light-brown oil $(186 \mathrm{mg})$. The residue was subjected to automated flash column chromatography (silica; $0 \rightarrow 30 \%$ EtOAc/hexanes) to provide previously unreported ketoester 24 (37 mg,0.16 mmol, 23\% yield) as a colorless amorphous solid.

${ }^{1} \mathrm{H}$ NMR $\left(400 \mathrm{MHz}\right.$, acetone- $\left.d_{6}\right): \delta 7.04(\mathrm{~d}, J=16.1 \mathrm{~Hz}, 1 \mathrm{H}), 6.71(\mathrm{~d}, J=16.1 \mathrm{~Hz}, 1 \mathrm{H}), 6.53(\mathrm{~m}$, $1 \mathrm{H}), 5.87(\mathrm{t}, J=3.4 \mathrm{~Hz}, 1 \mathrm{H}), 5.79(\mathrm{~m}, 1 \mathrm{H}), 4.24(\mathrm{q}, J=7.1 \mathrm{~Hz}, 2 \mathrm{H}), 3.56(\mathrm{~s}, 3 \mathrm{H}), 3.08(\mathrm{~m}, 2 \mathrm{H})$, $2.84(\mathrm{t}, J=2.8 \mathrm{~Hz}, 2 \mathrm{H}), 1.29(\mathrm{t}, J=7.1 \mathrm{~Hz}, 3 \mathrm{H}) \mathrm{ppm}$.

${ }^{13} \mathrm{C}$ NMR $\left(100 \mathrm{MHz}\right.$, acetone- $\left.d_{6}\right): \delta 199.4,166.0,140.3,132.2,131.2,122.0,107.1,106.3,61.8$, 40.9, 33.6, 20.7, $14.4 \mathrm{ppm}$.

IR (KBr): 1717, 1679, $1167 \mathrm{~cm}^{-1}$.

HRMS (ESI): $m / z$ calcd for $\mathrm{C}_{13} \mathrm{H}_{17} \mathrm{NO}_{3} \mathrm{Na}[\mathrm{M}+\mathrm{Na}]^{+} 258.1101$; found 258.1103. 
Bicyclic pyrrole 25

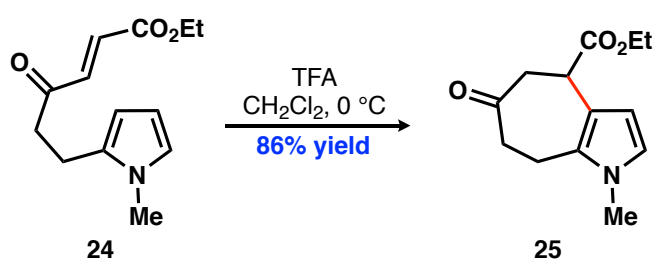

TFA (15 $\mu \mathrm{L}, 0.20 \mathrm{mmol}$ ) was added to a solution of $\alpha, \beta$-unsaturated ketone 24 (14 $\mathrm{mg}, 0.060$ $\mathrm{mmol})$ in $\mathrm{CH}_{2} \mathrm{Cl}_{2}(45 \mathrm{~mL})$ maintained at $0{ }^{\circ} \mathrm{C}$. After $0.75 \mathrm{~h}$ at $0{ }^{\circ} \mathrm{C}$, the reaction was proceeding very slowly (as judged by TLC), thus, additional TFA (50 $\mu \mathrm{L}, 0.65 \mathrm{mmol}$ ) was added. After $1 \mathrm{~h}$ at $0{ }^{\circ} \mathrm{C}, \mathrm{NaHCO}_{3}(20 \mathrm{~mL}$ of a saturated aqueous solution) was added. The ensuing biphasic mixture was stirred vigorously for $5 \mathrm{~min}$ and was allowed to warm to r.t. The organic phase was collected and the aqueous phase was extracted with $\mathrm{CH}_{2} \mathrm{Cl}_{2}(2 \times 10 \mathrm{~mL})$. The combined organic extracts were dried $\left(\mathrm{Na}_{2} \mathrm{SO}_{4}\right)$, filtered and concentrated to a volume of $\sim 2 \mathrm{~mL}$ then loaded onto a plug of silica gel and eluted with $30 \%$ EtOAc/hexanes $\left(+2 \% \mathrm{Et}_{3} \mathrm{~N}\right)$. Combination of the appropriate fractions afforded previously unreported bicyclic pyrrole 25 as a colorless oil $(12 \mathrm{mg}, 0.051 \mathrm{mmol}$, $86 \%$ yield).

${ }^{1} \mathrm{H}$ NMR $\left(600 \mathrm{MHz}\right.$, acetone- $\left.d_{6}\right): \delta 6.50(\mathrm{~d}, J=2.8 \mathrm{~Hz}, 1 \mathrm{H}), 5.87(\mathrm{~d}, J=2.8 \mathrm{~Hz}, 1 \mathrm{H}), 4.10(\mathrm{qd}, J$ $=7.1,2.0 \mathrm{~Hz}, 2 \mathrm{H}), 3.89$ (dd, $J=7.6,4.1 \mathrm{~Hz}, 1 \mathrm{H}), 3.53(\mathrm{~s}, 3 \mathrm{H}), 2.97(\mathrm{dd}, J=14.9,7.6 \mathrm{~Hz}, 1 \mathrm{H}$ ), 2.93 (ddd, $J=16.0,9.1,3.8 \mathrm{~Hz}, 1 \mathrm{H}), 2.85$ (ddd, $J=16.1,8.7,3.8 \mathrm{~Hz}, 1 \mathrm{H}), 2.80-2.74(\mathrm{~m}, 2 \mathrm{H})$, 2.66 (ddd, $J=14.4,8.8,3.5 \mathrm{~Hz}, 1 \mathrm{H}$ ), 1.21 (t, $J=7.1 \mathrm{~Hz}, 3 \mathrm{H}$ ) ppm.

${ }^{13} \mathrm{C}$ NMR $\left(150 \mathrm{MHz}\right.$, acetone- $\left.d_{6}\right): \delta 210.0,174.0,129.5,121.0,117.4,108.3,61.2,45.7,42.5$, 41.5, 34.0, 21.3, $14.5 \mathrm{ppm}$.

IR (KBr): 1730, $1706 \mathrm{~cm}^{-1}$.

HRMS (ESI): $m / z$ calcd for $\mathrm{C}_{13} \mathrm{H}_{17} \mathrm{NO}_{3} \mathrm{Na}[\mathrm{M}+\mathrm{Na}]^{+} 258.1101$; found 258.1102.

\section{Alcohols S15}
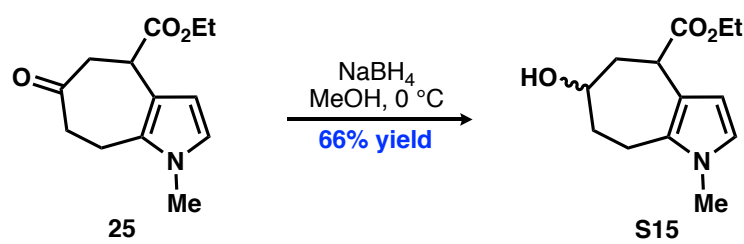

$\mathrm{NaBH}_{4}(2 \mathrm{mg}, 0.05 \mathrm{mmol})$ was added to a magnetically-stirred solution of ketone 25 (3 mg, 0.013 $\mathrm{mmol}$ ) in $\mathrm{MeOH}$ maintained at $0{ }^{\circ} \mathrm{C}$. After $1.5 \mathrm{~h}$ at $0{ }^{\circ} \mathrm{C}$, the reaction was quenched with $\mathrm{NH}_{4} \mathrm{Cl}$ $(0.2 \mathrm{~mL})$ and $\mathrm{H}_{2} \mathrm{O}(10 \mathrm{~mL})$ and the resulting solution was extracted with $\mathrm{CH}_{2} \mathrm{Cl}_{2}(3 \times 15 \mathrm{~mL})$. The combined $\mathrm{CH}_{2} \mathrm{Cl}_{2}$ extracts were dried $\left(\mathrm{Na}_{2} \mathrm{SO}_{4}\right)$, filtered and concentrated to yield a colorless oil (3 $\mathrm{mg}$ ) which contained alcohols $\mathbf{S 1 5}$ in 2:1 d.r. The residue was subjected to flash column chromatography (silica; $50 \%$ EtOAc/hexanes $+2 \% \mathrm{Et}_{3} \mathrm{~N}$ ) to provide chromatographicallyinseparable, previously unreported alcohols $\mathbf{S 1 5}(2 \mathrm{mg}, 0.0084 \mathrm{mmol})$ as a colorless oil.

\section{Major diastereomer S15a:}

${ }^{1} \mathrm{H}$ NMR $\left(600 \mathrm{MHz}\right.$, acetone- $\left.d_{6}\right): \delta 6.35(\mathrm{~d}, J=2.7 \mathrm{~Hz}, 1 \mathrm{H}), 5.73(\mathrm{~d}, J=2.7 \mathrm{~Hz}, 1 \mathrm{H}), 4.11-4.06$ (m, 3H), 3.81 (dd, J = 7.4, 3.0 Hz, 1H), 3.69 (d, J=4.2 Hz, 1H), $3.50(\mathrm{~s}, 3 \mathrm{H}), 2.82(\mathrm{~m}, 1 \mathrm{H}), 2.52$ (ddd, $J=15.7,10.9,2.3 \mathrm{~Hz}, 1 \mathrm{H}), 2.24$ (ddd, $J=13.4,7.4,3.1 \mathrm{~Hz}, 1 \mathrm{H}), 1.99(\mathrm{~m}, 1 \mathrm{H}), 1.80$ (ddd, $J$ $=13.5,8.3,3.0 \mathrm{~Hz}, 1 \mathrm{H}), 1.58(\mathrm{~m}, 1 \mathrm{H}), 1.22(\mathrm{t}, J=7.1 \mathrm{~Hz}, 3 \mathrm{H}) \mathrm{ppm}$.

${ }^{13} \mathrm{C}$ NMR $\left(150 \mathrm{MHz}\right.$, acetone- $\left.d_{6}\right): \delta 174.8,131.8,119.5,107.9,106.5,70.1,60.5,41.0,40.4,36.4$, 34.0, 20.5, $14.6 \mathrm{ppm}$.

HRMS (ESI): $m / z$ calcd for $\mathrm{C}_{13} \mathrm{H}_{19} \mathrm{NO}_{3} \mathrm{Na}[\mathrm{M}+\mathrm{Na}]^{+} 260.1257$; found 260.1251. 


\section{Additional Experiments}

\section{Ketone 23: structure elucidation}

The diastereoselective reduction of ketone 23 with $\mathrm{NaBH}_{4}$ delivered alcohol $\mathbf{S 5}$ efficiently. The 2D NMR spectroscopic data for alcohol S5 provide clear evidence for the 7-endo-trig cyclization of substrate 22. Notably, the COSY spectrum reveals that the methine proton adjacent to the hydroxy substituent $(\mathrm{H}-11)$ is coupled to two sets of methylene protons $\left(\mathrm{H}_{2}-10\right.$ and $\left.\mathrm{H}-12_{\mathrm{a}} / \mathrm{H}-12_{\mathrm{b}}\right)$. Correlations between $\mathrm{H}_{2}-10$ and $\mathrm{H}-9$ and $\mathrm{H}-12_{a} / \mathrm{H}-12_{b}$ and $\mathrm{H}-13$ are also evident (Figure S1). A full list of assignments for compound S5 including key COSY correlations is provided in Table S1. The NOESY spectrum for $\mathbf{S 5}$ shows a correlation between $\mathrm{H}-11$ and $\mathrm{H}-13$ and $\mathrm{H}-11$ and $\mathrm{H}-9$, which is consistent with a cis-relationship between these protons.

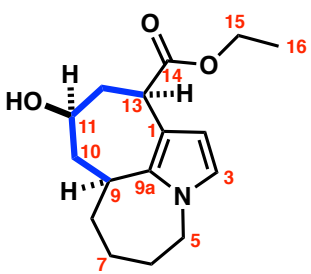

$( \pm)-\mathbf{S} 5$

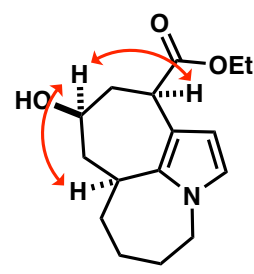

$( \pm)-\mathrm{S} 5$

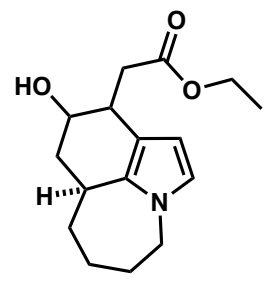

S16

Figure S1. Key ${ }^{1} \mathrm{H}-{ }^{1} \mathrm{H}$ COSY correlations for alcohol S5 indicated by bold blue bonds (left). Key NOESY correlations for alcohol S5 indicated by red arrows (center). Hypothetical product $\mathbf{S 1 6}$ of the 6-exo-trig cyclization of substrate 22 and subsequent ketone reduction (right).

Table S1. ${ }^{1} \mathrm{H},{ }^{13} \mathrm{C}$ and COSY NMR spectroscopic data for alcohol S5.

\begin{tabular}{|c|c|c|c|}
\hline Position & $\delta^{1} \mathrm{H}(\mathrm{ppm})$ & $\delta^{13} \mathrm{C}(\mathrm{ppm})$ & COSY correlations \\
\hline 1 & - & 118.9 & - \\
\hline 2 & $5.64(\mathrm{~d}, J=2.7 \mathrm{~Hz})$ & 107.6 & 3 \\
\hline 3 & $6.39(\mathrm{~d}, J=2.7 \mathrm{~Hz})$ & 120.0 & 2 \\
\hline $5 a$ & $3.97(\mathrm{~m}, 1 \mathrm{H})$ & 49.9 & $5 \mathrm{~b}, 6 \mathrm{a}, 6 \mathrm{~b}$ \\
\hline $5 b$ & $3.84(\mathrm{dd}, J=14.0,11.1, \mathrm{~Hz})$ & & $5 \mathrm{a}, 6 \mathrm{~b}$ \\
\hline $6 a$ & $1.91^{\mathrm{a}, \mathrm{b}}$ & 30.2 & - \\
\hline $6 b$ & $1.29^{a}$ & & $5 \mathrm{a}, 5 \mathrm{~b}, 7_{\mathrm{b}}$ \\
\hline $7 \mathrm{a}$ & $1.91^{\mathrm{a}, \mathrm{b}}$ & 30.5 & - \\
\hline $7 \mathrm{~b}$ & $1.62(\mathrm{~m})$ & & $6 \mathrm{~b}, 8_{\mathrm{a}}, 8_{\mathrm{b}}$ \\
\hline $8 a$ & $1.79(\mathrm{~m})$ & 35.6 & $7 \mathrm{~b}, 8_{\mathrm{b}}$ \\
\hline $8 b$ & $1.38^{\mathrm{a}}$ & & $7 \mathrm{~b}, 8 \mathrm{a}, 9$ \\
\hline 9 & 3.01 (quint, $J=5.2 \mathrm{~Hz}$ ) & 35.2 & $8 b, 10$ \\
\hline $9 a$ & - & 134.8 & - \\
\hline 10 & $2.07^{a}$ & 42.8 & 9,11 \\
\hline 11 & $4.06(\mathrm{~m})$ & 68.0 & $\mathrm{OH}, 10,12_{a}, 12_{b}$ \\
\hline $12 \mathrm{a}$ & $2.28(\mathrm{ddd}, J=14.2,6.1,3.1 \mathrm{~Hz})$ & 41.5 & $11,12 \mathrm{~b}, 13$ \\
\hline $12 b$ & $2.10^{\mathrm{a}}$ & & $11,12_{\mathrm{a}}, 13$ \\
\hline 13 & $3.68(\mathrm{dd}, J=9.1,3.1 \mathrm{~Hz})$ & 42.3 & $12 \mathrm{a}, 12 \mathrm{~b}$ \\
\hline 14 & - & 175.9 & - \\
\hline 15 & $4.14(\mathrm{q}, J=7.1 \mathrm{~Hz})$ & 60.8 & 16 \\
\hline 16 & $1.24(\mathrm{t}, J=7.1 \mathrm{~Hz})$ & 14.5 & 15 \\
\hline $\mathrm{OH}$ & $3.72(\mathrm{~d}, J=6.0 \mathrm{~Hz})$ & - & 11 \\
\hline
\end{tabular}

aSignal overlaps with other resonances.

${ }^{b} \mathrm{COSY}$ correlations involving $\mathrm{H}-6_{\mathrm{a}}$ and $\mathrm{H}-7_{\mathrm{a}}$ have not been included due to the overlap of these signals. 
Ketone 25: structure elucidation

Reduction of ketone 25 with $\mathrm{NaBH}_{4}$ delivered alcohols $\mathbf{S 1 5}$ as a 2:1 mixture of diastereomers. Significantly, the COSY spectrum of $\mathbf{S} 15$ revealed correlations between $\mathrm{H}-9$ and $\mathrm{H}-\mathrm{-}_{\mathrm{a}} / \mathrm{H}-\mathrm{8}_{\mathrm{b}}$ and $\mathrm{H}-9$ and $\mathrm{H}-10_{a} / \mathrm{H}-10_{b}$ (Figure S2), which supports the 7-endo cyclization mode of substrate 24 shown in Scheme 3B. A summary of the assignments for the major diastereomer S15a including COSY correlations is provided in Table S2.
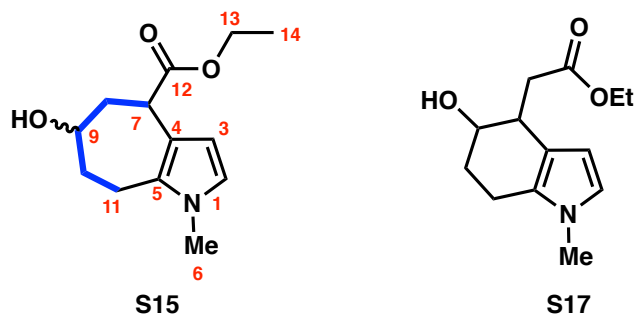

Figure S2. Key ${ }^{1} \mathrm{H}-{ }^{1} \mathrm{H}$ COSY correlations for alcohol S15 (left). Hypothetical product S17 of the 6-exo-trig cyclization of substrate $\mathbf{2 4}$ and subsequent ketone reduction (right).

Table S2. ${ }^{1} \mathrm{H},{ }^{13} \mathrm{C}$ and COSY NMR spectroscopic data for alcohol S15a.

\begin{tabular}{|c|c|c|c|}
\hline Position & $\boldsymbol{\delta}^{1} \mathbf{H}(\mathbf{p p m})$ & $\boldsymbol{\delta}^{13} \mathbf{C}(\mathbf{p p m})$ & COSY correlations \\
\hline 2 & $6.35(\mathrm{~d}, J=2.7 \mathrm{~Hz})$ & 119.5 & 3 \\
3 & $5.73(\mathrm{~d}, J=2.7 \mathrm{~Hz})$ & 107.9 & 2 \\
4 & - & 106.5 & - \\
5 & - & 131.8 & - \\
6 & $3.50(\mathrm{~s})$ & 34.0 & - \\
7 & $3.81(\mathrm{dd}, J=7.4,3.0 \mathrm{~Hz})$ & 41.0 & $8 \mathrm{a}, 8_{\mathrm{b}}$ \\
$8 \mathrm{a}$ & $2.24(\mathrm{ddd}, J=13.4,7.4,3.1 \mathrm{~Hz})$ & 40.4 & $7,8_{\mathrm{b}}, 9$ \\
$8 \mathrm{~b}$ & $1.80(\mathrm{ddd}, J=13.5,8.3,3.0 \mathrm{~Hz})$ & & $7,8_{\mathrm{a}}, 9$ \\
9 & $4.08^{\mathrm{a}}$ & 70.1 & $8 \mathrm{a}, 8 \mathrm{~b}, 10_{\mathrm{a}}, 10_{\mathrm{b}}, \mathrm{OH}$ \\
$10 \mathrm{a}$ & $1.99(\mathrm{~m})$ & 36.4 & $9,10_{\mathrm{b}}, 11_{\mathrm{a}}, 11_{\mathrm{b}}$ \\
$10 \mathrm{~b}$ & $1.58(\mathrm{~m})$ & & $9,10 \mathrm{a}, 11_{\mathrm{a}}, 11_{\mathrm{b}}$ \\
$11_{\mathrm{a}}$ & $2.82(\mathrm{~m})$ & 20.5 & $10_{\mathrm{a}}, 10_{\mathrm{b}}, 11_{\mathrm{b}}$ \\
$11_{\mathrm{b}}$ & $2.52(\mathrm{ddd}, \mathrm{J}=15.7,10.9,2.3 \mathrm{~Hz})$ & & $10 \mathrm{a}, 10_{\mathrm{b}}, 11_{\mathrm{a}}$ \\
12 & - & 174.8 & - \\
13 & $4.10^{\mathrm{a}}$ & 60.5 & 14 \\
14 & $1.22(\mathrm{t}, J=7.1 \mathrm{~Hz})$ & 14.6 & 13 \\
$\mathrm{OH}$ & $3.69(\mathrm{~d}, J=4.2 \mathrm{~Hz})$ & - & 9 \\
\hline
\end{tabular}

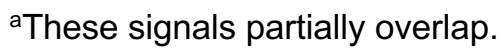




\section{Bicyclic pyrrole S19: overview}

The cyclization of pyrrole $\mathbf{S} 18$ was explored with a range of Brønsted and Lewis acid promoters (Table S3). Bicyclic pyrroles S19 were isolated in excellent yield when both TFA (3 equiv) and $\mathrm{Sc}(\mathrm{OTf})_{3}(0.3$ equiv) were utilized as mediators, however, the latter provided the annulated products in a substantially greater d.r.

Table S3. Investigating synthesis of pyrroloazepine S19 via the cyclization of pyrrole S18.

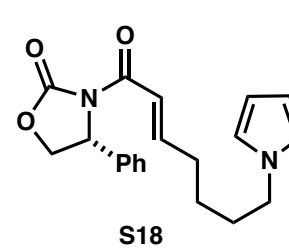

S18

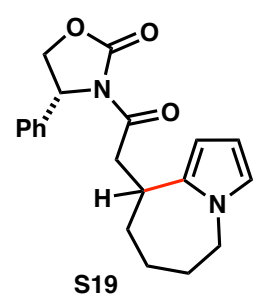

S19

\begin{tabular}{ccccccc} 
entry & Lewis or Brønsted acid & temperature $\left({ }^{\circ} \mathbf{C}\right)$ & time $(\mathbf{h})$ & $\begin{array}{c}\text { ratio } \\
\text { S19:S18 }\end{array}$ & d.r. & comments \\
1 & 3 equiv TFA & 0 & 3 & $28: 72$ & $1.9: 1$ & \\
2 & 3 equiv TFA & r.t. & 5 & $100: 0$ & $1.5: 1$ & $>99 \%$ isolated yield \\
3 & 2 equiv $\mathrm{MsOH}$ & $-78 \rightarrow-10$ & 2 & $100: 0$ & $2.4: 1$ & \\
4 & 2 equiv $\mathrm{MsOH}$ & -40 & 0.25 & $40: 60$ & $3.1: 1$ & \\
5 & 2 equiv $\mathrm{MsOH}$ & -50 & 0.67 & $50: 50$ & $4: 1$ & \\
6 & 2 equiv $\mathrm{TfOH}$ & -78 & 0.33 & $0: 100$ & - & no reaction \\
7 & 2 equiv $\mathrm{TfOH}$ & -40 & 0.33 & $0: 100$ & - & decomposition \\
8 & 0.6 equiv $\mathrm{CuBr}{ }_{2}$ & 0 & 1.5 & $9: 91$ & $2: 1$ & \\
9 & 0.3 equiv $\mathrm{Cu}(\mathrm{OTf})_{2}$ & 0 & 1.5 & $0: 100$ & - & no reaction \\
$10^{\mathrm{a}}$ & 0.2 equiv $\mathrm{Sc}(\mathrm{OTf})_{3}$ & 0 & 2.5 & $100: 0$ & $4.5: 1$ & $>95 \%$ isolated yield \\
11 & 0.2 equiv $\mathrm{Sc}(\mathrm{OTf})_{3}$ & $-15 \rightarrow-10$ & 2.5 & $100: 0$ & $5.4: 1$ & \\
12 & 0.2 equiv $\mathrm{Sc}(\mathrm{OTf})_{3}$ & $-25 \rightarrow-15$ & 1.5 & $40: 60$ & $5: 1$ & \\
13 & 0.2 equiv $\mathrm{Sc}(\mathrm{OTf})_{3}$ & $-40 \rightarrow-25$ & 2 & $0: 100$ & - & no reaction \\
14 & 0.2 equiv $\mathrm{Ga}(\mathrm{OTf})_{3}$ & 0 & 1 & $0: 100$ & - & no reaction \\
\hline
\end{tabular}

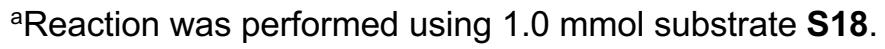

Bicyclic pyrrole S19: general procedure for cyclization reactions of substrate S18

The Lewis or Brønsted acid was added to a magnetically-stirred solution of $\mathrm{N}$-acyl oxazolidinone S18 $\left(\sim 0.07 \mathrm{mmol}\right.$ scale unless otherwise specified) in $\mathrm{CH}_{2} \mathrm{Cl}_{2}(3 \mathrm{mM})$ maintained at the specified temperature (Table S3). After the specified time, the reaction was quenched with $\mathrm{NaHCO}_{3}(5 \mathrm{~mL})$ and the aqueous phase was extracted with $\mathrm{CH}_{2} \mathrm{Cl}_{2}(3 \times 5 \mathrm{~mL})$. The combined $\mathrm{CH}_{2} \mathrm{Cl}_{2}$ extracts were dried $\left(\mathrm{MgSO}_{4}\right)$, filtered and concentrated. The reaction was analyzed by ${ }^{1} \mathrm{H} \mathrm{NMR}$ spectroscopy. With the exception of two reactions (Table S3, entries 2 and 10), the respective crude residue obtained was not purified. The respective crude residues of two reactions (Table S3, entries 2 and 10) were eluted through a plug of silica gel (40\% EtOAc/hexanes). 


\section{Pyrroloazepine 7: overview of synthesis via the cyclization of ketoester 9}

$\alpha, \beta$-Unsaturated ketoester $\mathbf{9}$ was successfully synthesized from aldehyde $\mathbf{S 2 0}$ via a Knoevenagel condensation with ethyl acetoacetate (Scheme S1). However, this particularly sensitive substrate could not be isolated by flash column chromatography (silica) and thus was subjected to the acidmediated cyclization without prior purification. As anticipated when treated with TFA at $0{ }^{\circ} \mathrm{C}$, facile cyclization of substrate $\mathbf{9}$ (which bears a highly-activated Michael acceptor) occurred to provide pyrroloazepine 10. This sensitive compound was converted to chromatographically-stable pyrroloazepine 7, via reduction of the ketone with $\mathrm{NaBH}_{4}$, mesylation, elimination of the ensuing mesylate (DBU in DMF) and hydrogenation of alkene S22.

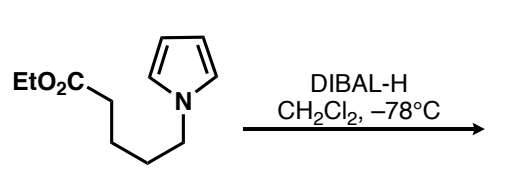

s1

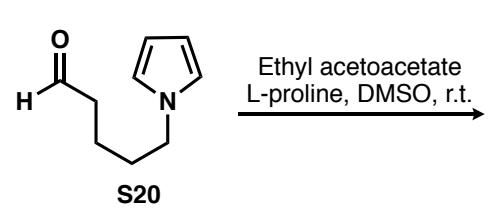

S20
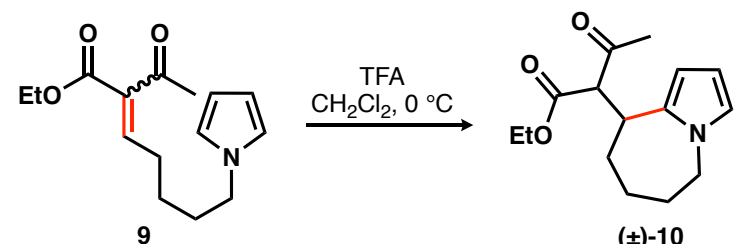

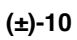

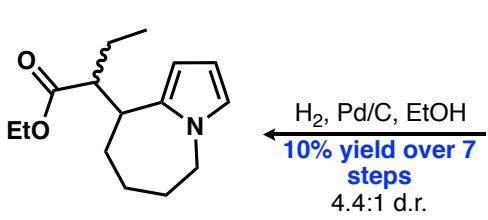

7

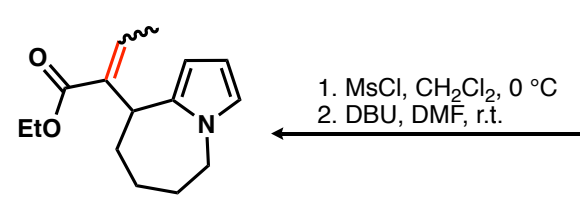

(士)-S22

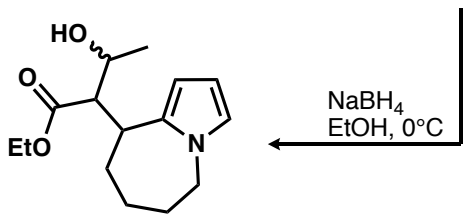

(士)-S21

Scheme S1. Synthesis of pyrroloazepine 7 employing a TFA-mediated cyclization of substrate 9.

\section{Pyrroloazepine 7}

Step $i$. DIBAL-H (45 $\mathrm{mL}$ of a $1 \mathrm{M}$ solution in hexanes, $45 \mathrm{mmol}$ ) was added dropwise to a magnetically-stirred solution of ester $\mathbf{S 1}(8.88 \mathrm{~g}, 45 \mathrm{mmol})$ in $\mathrm{CH}_{2} \mathrm{Cl}_{2}(200 \mathrm{~mL})$ maintained at -78 ${ }^{\circ} \mathrm{C}$. The solution was maintained at $-78^{\circ} \mathrm{C}$ for $1 \mathrm{~h}$ before the addition of $\mathrm{NH}_{4} \mathrm{Cl}$ (saturated aqueous solution) $(30 \mathrm{~mL}), \mathrm{H}_{2} \mathrm{O}(300 \mathrm{~mL})$ and $\mathrm{Et}_{2} \mathrm{O}(400 \mathrm{~mL})$. The ensuing mixture was allowed to warm to r.t. then $\mathrm{KHSO}_{4}$ (saturated aqueous solution) was added to dissolve insoluble salts. The organic phase was collected and the aqueous phase was further extracted with $\mathrm{Et}_{2} \mathrm{O}(2 \times 100 \mathrm{~mL})$. The combined $\mathrm{Et}_{2} \mathrm{O}$ extracts were dried $\left(\mathrm{MgSO}_{4}\right)$, filtered, and concentrated to provide crude aldehyde S20 (7.09 g) as a colorless oil. Particularly sensitive aldehyde S20 was not isolated, but was immediately subjected to the next step described below.

Step ii. Ethyl acetoacetate $(11.5 \mathrm{~mL}, 90 \mathrm{mmol})$ and $L$-proline $(1.55 \mathrm{~g}, 13.5 \mathrm{mmol})$ were added to a magnetically-stirred solution of aldehyde $\mathbf{S 2 0}(7.09 \mathrm{~g})$ in DMSO $(35 \mathrm{~mL})$. After $1 \mathrm{~h}$ at r.t., $\mathrm{H}_{2} \mathrm{O}$ $(30 \mathrm{~mL})$ was added and the ensuing mixture was extracted with $\mathrm{Et}_{2} \mathrm{O}(3 \times 30 \mathrm{~mL})$. The combined organic extracts were washed with $\mathrm{H}_{2} \mathrm{O}(3 \times 30 \mathrm{~mL})$ and brine $(1 \times 30 \mathrm{~mL})$, dried $\left(\mathrm{MgSO}_{4}\right)$, filtered, and concentrated to provide crude $\alpha, \beta$-unsaturated ketoester $\mathbf{9}$. Particularly sensitive ketoester 9 was not isolated, but was immediately subjected to the next step described below.

Step iii. TFA (6.9 mL, $90 \mathrm{mmol}$ ) was added dropwise to a magnetically-stirred solution of $\alpha, \beta-$ unsaturated ketoester 9 (from step ii) in $\mathrm{CH}_{2} \mathrm{Cl}_{2}\left(1 \mathrm{~L}\right.$ ) maintained at $0{ }^{\circ} \mathrm{C}$. After $0.5 \mathrm{~h}$ at $0{ }^{\circ} \mathrm{C}$, $\mathrm{NaHCO}_{3}(300 \mathrm{~mL}$ of a saturated aqueous solution) was added and the resulting biphasic mixture was stirred for $10 \mathrm{~min}$. The $\mathrm{CH}_{2} \mathrm{Cl}_{2}$ phase was collected and the aqueous phase was extracted with $\mathrm{CH}_{2} \mathrm{Cl}_{2}(2 \times 100 \mathrm{~mL})$. The combined $\mathrm{CH}_{2} \mathrm{Cl}_{2}$ extracts were dried $\left(\mathrm{MgSO}_{4}\right)$, filtered, and concentrated to yield a dark-brown residue, which darkened upon concentration in the rotary evaporator. Particularly sensitive pyrroloazepine $\mathbf{1 0}$ was not isolated, but was immediately subjected to the next step described below. 
Step iv. $\mathrm{NaBH}_{4}(6.0 \mathrm{~g}, 159 \mathrm{mmol})$ was added to a magnetically-stirred solution of crude pyrroloazepine 10 (from step iii) in $\mathrm{EtOH}(100 \mathrm{~mL})$ maintained at $0{ }^{\circ} \mathrm{C}$. After addition, the solution was allowed to warm to r.t. over $0.75 \mathrm{~h}$ then was quenched with $\mathrm{NH}_{4} \mathrm{Cl}(20 \mathrm{~mL}$ of a saturated aqueous solution) and $\mathrm{H}_{2} \mathrm{O}(30 \mathrm{~mL})$. The resulting mixture was extracted with $\mathrm{CH}_{2} \mathrm{Cl}_{2}(3 \times 40 \mathrm{~mL})$ and the combined $\mathrm{CH}_{2} \mathrm{Cl}_{2}$ extracts were dried $\left(\mathrm{MgSO}_{4}\right)$, filtered, and concentrated to provide a yellow oil $(10.5 \mathrm{~g})$. The residue was fractionated through a plug of silica $(40 \% \mathrm{EtOAc} / \mathrm{hexanes}+$ $\left.1.5 \% \mathrm{Et}_{3} \mathrm{~N}\right)$ to provide an impure sample of alcohol $\mathbf{S 2 1}$ as a a yellow oil $(5.63 \mathrm{~g})$. Particularly sensitive $\mathbf{S 2 1}$ was not isolated, but was immediately subjected to the next step described below.

Step v. MsCl (1.8 mL, $23 \mathrm{mmol})$ was added dropwise to a magnetically-stirred solution of crude alcohol S21 $(5.63 \mathrm{~g})$ and $\mathrm{Et}_{3} \mathrm{~N}(3.6 \mathrm{~mL}, 26 \mathrm{mmol})$ in $\mathrm{CH}_{2} \mathrm{Cl}_{2}(50 \mathrm{~mL})$ maintained at $0{ }^{\circ} \mathrm{C}$. After 0.5 $\mathrm{h}$ at $0{ }^{\circ} \mathrm{C}, \mathrm{H}_{2} \mathrm{O}(30 \mathrm{~mL})$ was added and the aqueous phase was extracted with $\mathrm{CH}_{2} \mathrm{Cl}_{2}(3 \times 30$ $\mathrm{mL}$ ). The combined $\mathrm{CH}_{2} \mathrm{Cl}_{2}$ extracts were washed with $\mathrm{KHSO}_{4}$ (30 mL of $\sim 1 \mathrm{M}$ solution) and $\mathrm{NaHCO}_{3}$ (saturated aqueous solution), dried $\left(\mathrm{MgSO}_{4}\right)$, filtered, and concentrated to provide the crude mesylate as a dark-brown oil $(\sim 5 \mathrm{~g})$. The particularly sensitive mesylate was not isolated, but was immediately subjected to the next step described below.

Step vi. DBU $(3.2 \mathrm{~mL}, 43 \mathrm{mmol})$ was added to a magnetically-stirred solution of the crude mesylate $(\sim 5 \mathrm{~g}$, from step $v)$ in DMF $(50 \mathrm{~mL})$, maintained at $0{ }^{\circ} \mathrm{C}$. The solution was allowed to warm slowly to r.t. and was maintained at this temperature for $16 \mathrm{~h}$, before the addition $\mathrm{H}_{2} \mathrm{O}(50$ $\mathrm{mL})$. The ensuing mixture was extracted with $\mathrm{Et}_{2} \mathrm{O}(3 \times 30 \mathrm{~mL})$ and the combined $\mathrm{Et}_{2} \mathrm{O}$ extracts were washed with $\mathrm{H}_{2} \mathrm{O}(3 \times 30 \mathrm{~mL}), \mathrm{KHSO}_{4}(2 \times 30 \mathrm{~mL}$ of a 1 M solution) and brine $(30 \mathrm{~mL})$, then were dried $\left(\mathrm{MgSO}_{4}\right)$, filtered, and concentrated to provide crude alkene $\mathbf{S 2 2}$ as a brown oil $(3.2 \mathrm{~g})$. The residue was passed through a plug of silica $\left(40 \% \mathrm{EtOAc} /\right.$ hexanes $\left.+1.5 \% \mathrm{Et}_{3} \mathrm{~N}\right)$ to provide an impure sample of alkene $\mathbf{S 2 2}(3.0 \mathrm{~g})$ which was subjected to the next step without further purification. However, in a separate experiment, a sample of crude alkene $\mathbf{S 2 2}$ was subjected to automated flash chromatography $(0 \rightarrow 25 \%$ EtOAc/hexanes $)$ to provide an pure sample of previously unreported alkene $\mathbf{S 2 2}$ as colorless needles.

m.p. $54-58{ }^{\circ} \mathrm{C}$.

${ }^{1} \mathrm{H}$ NMR (400 MHz, acetone- $\left.d_{6}\right): \delta 6.94(\mathrm{q}, J=7.4 \mathrm{~Hz}, 1 \mathrm{H}), 6.53(\mathrm{~m}, 1 \mathrm{H}), 5.76(\mathrm{~m}, 1 \mathrm{H}), 5.56(\mathrm{~m}$, $1 \mathrm{H}), 4.18-4.06(\mathrm{~m}, 4 \mathrm{H}), 3.88(\mathrm{dd}, J=14.3,11.6 \mathrm{~Hz}, 1 \mathrm{H}), 2.10-1.96(\mathrm{~m}$, overlapping with residual solvent signal, $3 \mathrm{H}), 1.84-1.78(\mathrm{~m}, 4 \mathrm{H}), 1.65(\mathrm{~m}, 1 \mathrm{H}), 1.50(\mathrm{~m}, 1 \mathrm{H}), 1.24(\mathrm{t}, J=7.1 \mathrm{~Hz}, 3 \mathrm{H}) \mathrm{ppm}$. ${ }^{13} \mathrm{C}$ NMR $\left(100 \mathrm{MHz}\right.$, acetone- $\left.d_{6}\right): \delta 168.0,138.4,136.9,135.2,122.3,107.0,106.0,60.8,50.5$, 38.9, 35.0, 31.6, 30.6, 15.2, $14.6 \mathrm{ppm}$.

IR (KBr): $1708,1255 \mathrm{~cm}^{-1}$.

HRMS (ESI): $m / z$ calcd for $\mathrm{C}_{15} \mathrm{H}_{21} \mathrm{NO}_{2} \mathrm{Na}[\mathrm{M}+\mathrm{Na}]^{+} 270.1465$; found 270.1458.

Step vii. Palladium on carbon $(1.3 \mathrm{~g}$ of $10 \% \mathrm{Pd} / \mathrm{C}, 1.2 \mathrm{mmol})$ was added to a solution of crude alkene S22 $(3.0 \mathrm{~g})$ in $\mathrm{EtOH}(100 \mathrm{~mL})$ and the ensuing mixture was placed under an atmosphere of $\mathrm{H}_{2}$ (40 psi) with shaking for $10 \mathrm{~h}$. After this time, the suspension was filtered through a plug of celite with $\mathrm{MeOH}$ and was concentrated to provide a colorless oil $(2.40 \mathrm{~g})$, which was subjected to automated flash column chromatography $(0 \rightarrow 10 \%$ EtOAc/hexanes) to provide previously reported $\alpha$-ethylated esters 7 (1.16 g, $4.7 \mathrm{mmol}, 4.4: 1 \mathrm{~d} . \mathrm{r} ., 10 \%$ yield over 7 steps) as a colorless oil. ${ }^{4,5}$ The ${ }^{1} \mathrm{H}$ NMR spectrum of esters 7 is provided on page S-101. 
Tetrahydroindolizine 16: synthesis via cyclization of $\alpha, \beta$-unsaturated ester 15 (overview)

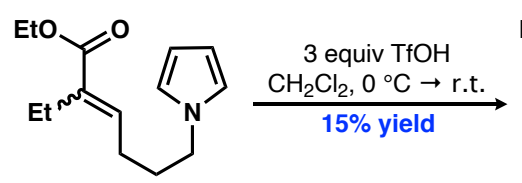

15<smiles>CCOC(=O)C(CC)C1CCCn2cccc21</smiles>

16

Cyclization of pyrrole 15 was attempted via treatment of the substrate with both $\mathrm{MsOH}$ and $\mathrm{TfOH}$ and the latter was found to mediate the reaction with much greater efficiency. Formation of bicyclic pyrrole 16 was not observed (by TLC analysis) when substrate 15 was exposed to 3 equivalents of $\mathrm{TfOH}$ at $0{ }^{\circ} \mathrm{C}$ for $4 \mathrm{~h}$. In addition, when this reaction was warmed to r.t. and maintained at this temperature for $2 \mathrm{~h}$, product 16 was not detected. Ultimately, the temperature was maintained at r.t. for a further $16 \mathrm{~h}$ before the reaction outcome was analyzed via quantitative ${ }^{1} \mathrm{H} N M R$ spectroscopy. In this way, the yield of bicyclic pyrrole 16 was determined to be $15 \%$. In addition, starting material 15 was recovered in $63 \%$ yield. The authentic product 16 was synthesized via $\alpha$-alkylation of ester $\mathbf{S 2 3}$ (vide infra) and used for analysis of the reaction outcome.

Tetrahydroindolizine 16: synthesis of authentic product via (post cyclization) $\alpha$-ethylation

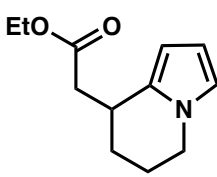

$( \pm)-\mathbf{S 2 3}$

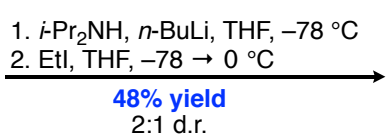

2:1 d.r.

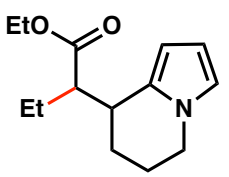

$( \pm)-16$

$n$-BuLi ( $1.1 \mathrm{~mL}$ of a $2.5 \mathrm{M}$ solution in hexanes, $2.8 \mathrm{mmol}$ ) was added dropwise to a magneticallystirred solution of diisopropylamine $(370 \mu \mathrm{L}, 2.6 \mathrm{mmol})$ in THF $(20 \mathrm{~mL})$ maintained at $-78^{\circ} \mathrm{C}$. After $0.25 \mathrm{~h}$ at $-78{ }^{\circ} \mathrm{C}$, a solution of ester $\mathbf{S} 23(493 \mathrm{mg}, 2.38 \mathrm{mmol})$ in THF $(8 \mathrm{~mL})$ was added dropwise and the ensuing solution was maintained at $-78{ }^{\circ} \mathrm{C}$ for $40 \mathrm{~min}$, and then was allowed to warm to $0{ }^{\circ} \mathrm{C}$ over $3.5 \mathrm{~h}$. The reaction was quenched by the addition of $\mathrm{NH}_{4} \mathrm{Cl}(10 \mathrm{~mL})$ and $\mathrm{H}_{2} \mathrm{O}$ $(30 \mathrm{~mL})$. The resulting mixture was extracted with $\mathrm{Et}_{2} \mathrm{O}(3 \times 10 \mathrm{~mL})$. The combined $\mathrm{Et}_{2} \mathrm{O}$ extracts were washed with $\mathrm{KHSO}_{4}\left(30 \mathrm{~mL}\right.$ of a $1 \mathrm{M}$ aqueous solution) and $\mathrm{NaHCO}_{3}(30 \mathrm{~mL}$ of a saturated aqueous solution), dried $\left(\mathrm{Na}_{2} \mathrm{SO}_{4}\right)$, filtered and concentrated to afford a light-yellow oil, which was subkected to automated flash column chromatography (silica; $0 \rightarrow 10 \% \mathrm{EtOAc/hexanes)} \mathrm{to}$ provide chromatographically inseparable, previously unreported tetrahydroindolizines 16 (271 $\mathrm{mg}, 1.15 \mathrm{mmol}, 48 \%$ yield, 2:1 d.r.) as colorless oil and starting material S23 $(60 \mathrm{mg}, 0.29 \mathrm{mmol}$, $12 \%$ yield) as a colorless oil. The ${ }^{1} \mathrm{H}$ and ${ }^{13} \mathrm{C}$ NMR spectra for tetrahydroindolizines 16 are provided on pages S-102-104.

HRMS (ESI): $m / z$ calcd for $\mathrm{C}_{14} \mathrm{H}_{21} \mathrm{NO}_{2} \mathrm{Na}[\mathrm{M}+\mathrm{Na}]^{+} 258.1465$; found 258.1459.

\section{Attempted synthesis of hydroxyketone S24: overview}

We intended to synthesize $\alpha, \beta$-unsaturated diketone 26 via the cross-metathesis of vinyl alcohol S3 with methyl vinyl ketone, followed by a Parikh-Doering oxidation of alcohol S24. This strategy had been successfully applied to synthesize $\alpha, \beta$-unsaturated ketoesters 22 and $\mathbf{2 4}$. However, the ${ }^{1} \mathrm{H}$ NMR spectrum of the crude cross-metathesis reaction products (in acetone- $d_{6}$ ) revealed that the major product was in fact tricyclic pyrrole $\mathbf{5 2 5}$, formed in situ under the reaction conditions (Scheme S2). Intended bicyclic alcohol S24 was not observed. 


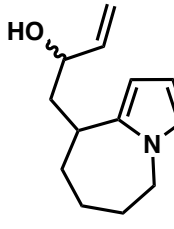

(土)-S3
Hoveyda-Grubbs II cat MVK, $\mathrm{CH}_{2} \mathrm{Cl}_{2}, 40^{\circ} \mathrm{C}$

$\mathrm{N}, \mathrm{CH}_{2} \mathrm{Cl}_{2}, 40^{\circ} \mathrm{C}$

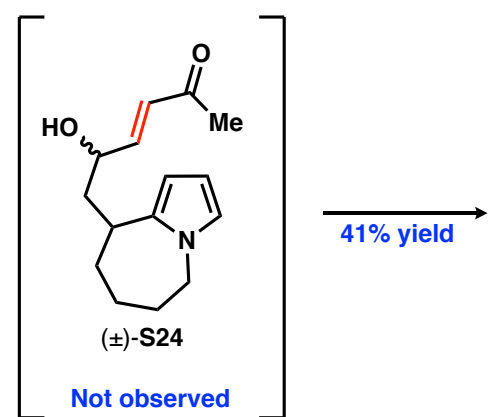

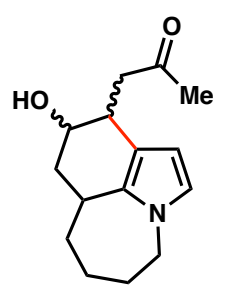

(土)-S25

Scheme S2. Synthesis and in situ cyclization of pyrrole S24 under the cross-metathesis reaction conditions.

\section{Tricyclic pyrrole S25}

Methyl vinyl ketone $(65 \mu \mathrm{L}, 0.78 \mathrm{mmol})$ and Hoveyda-Grubbs II catalyst $(18 \mathrm{mg}, 0.029 \mathrm{mmol})$ were added to a magnetically-stirred solution of vinyl alcohol $\mathbf{S} 3(80 \mathrm{mg}, 0.39 \mathrm{mmol})$ in $\mathrm{CH}_{2} \mathrm{Cl}_{2}$ (4 $\mathrm{mL}$ ) and the resulting solution was heated at reflux (Al block). After $18 \mathrm{~h}$, the solution was cooled to r.t. then quenched with ethyl vinyl ether. The solution was concentrated to provide a dark-brown oil and the ensuing residue was subjected to automated flash column chromatography $(0 \rightarrow 40 \%$ EtOAc/hexanes) to provide alcohols S25 as a mixture of four, previously unreported, chromatographically-inseparable diastereomers $(40 \mathrm{mg}, 0.16 \mathrm{mmol}, 41 \%$ yield) as a colorless oil. The ${ }^{1} \mathrm{H}$ and ${ }^{13} \mathrm{C}$ NMR spectra for compounds S25 are provided on pages S-105-107. HRMS (ESI): $\mathrm{m} / \mathrm{z}$ calcd for $\mathrm{C}_{15} \mathrm{H}_{21} \mathrm{NO}_{2} \mathrm{Na}[\mathrm{M}+\mathrm{Na}] 270.1465$; found 270.1459 .

\section{Attempted cyclization of substrate 8}

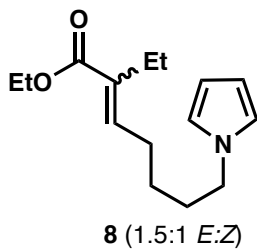

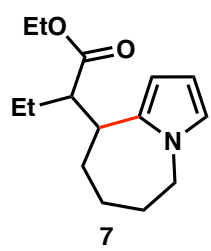

entry

1

2

3

4

5

\section{Lewis or Brønsted acid}

3 equiv $\mathrm{MsOH}$

3 equiv $\mathrm{MsOH}$

3 equiv $\mathrm{TfOH}$

5 equiv $\mathrm{AlCl}_{3}(0.06 \mathrm{M})$

3 equiv TMSOTf

\section{conditions}

$\mathrm{CH}_{2} \mathrm{Cl}_{2}$, r.t., $5 \mathrm{~h}$

$\mathrm{CH}_{2} \mathrm{Cl}_{2}, 40{ }^{\circ} \mathrm{C}, 3 \mathrm{~h}$

$\mathrm{CH}_{2} \mathrm{Cl}_{2}$, r.t., $24 \mathrm{~h}$

$\mathrm{Et}_{2} \mathrm{O}$, r.t., $18 \mathrm{~h}$

$\mathrm{CH}_{2} \mathrm{Cl}_{2}$, r.t., $18 \mathrm{~h}$

\section{comments}

Recovered 8

Recovered 8

Recovered $\mathbf{8}+$ minor decomposition

Recovered $\mathbf{8}$ + decomposition

Recovered 8

\section{General Procedure}

The Brønsted or Lewis acid was added to a magnetically-stirred solution of substrate $8(\sim 30 \mathrm{mg}$, $0.12 \mathrm{mmol})$ in the specified solvent $(0.01 \mathrm{M}$ unless otherwise noted) and was maintained at r.t. or heated for the stated time. Reaction progress was monitored by TLC. After the specified time, the mixture was allowed to cool to r.t. (if relevant) then was quenched with $\mathrm{NaHCO}_{3}(5 \mathrm{~mL}$ of a saturated aqueous solution) or water $(30 \mathrm{~mL})$ (entry 4 only). The ensuing mixture was extracted with $\mathrm{CH}_{2} \mathrm{Cl}_{2}(3 \times 5 \mathrm{~mL})$ and the combined $\mathrm{CH}_{2} \mathrm{Cl}_{2}$ extracts were dried, filtered, and concentrated to provide a crude residue, that was analyzed by ${ }^{1} \mathrm{H}$ NMR spectroscopy. 


\section{X-Ray Crystallographic Data}

Crystals were grown by slow evaporation from $\mathrm{Et}_{2} \mathrm{O} / n$-pentane solution at $4{ }^{\circ} \mathrm{C}$. Data for tricyclic pyrrole S9 were collected at $100 \mathrm{~K}$ using $\mathrm{Cu}$-Ka radiation (microsource, mirror monochromated) using an Agilent SuperNova diffractometer with Atlas detector. Several data sets were collected, with evidence of crystal twinning observed for all; the best data set has been used here. The structure was solved by direct methods with SHELXT-2014, refined using full-matrix least-squares routines against $F^{2}$ with SHELXL-2014, ${ }^{8}$ and visualized using the X-Seed ${ }^{9}$ interface. All nonhydrogen atoms were refined anisotropically. All hydrogen atoms attached to carbon were placed in calculated positions and refined using a riding model with fixed $\mathrm{C}-\mathrm{H}$ distances of $0.95 \AA$ $\left(s p^{2} \mathrm{CH}\right), 1.00\left(s p^{3} \mathrm{CH}\right), 0.99 \AA\left(\mathrm{CH}_{2}\right)$. The displacement parameters of hydrogen atoms were estimated as $U_{\text {iso }}(H)=1.2 U_{\text {eq }}(C)$. CCDC-2102770 contains the supplementary crystallographic data for this paper. These data can be obtained free of charge from The Cambridge Crystallographic Data Centre via http://www.ccdc.cam.ac.uk/data request/cif. Crystal data for tricyclic pyrrole S9: $\mathrm{C}_{13} \mathrm{H}_{17} \mathrm{NO}, M=203.27$, monoclinic, $a=17.6738(4), b=8.8186(2), c=$ $15.0407(3) \AA, \beta=113.409(3)^{\circ}, V=2151.27(9) \AA^{3}, T=100 \mathrm{~K}$, space group $P 2{ }_{1} / c$ (no. 14 ), $Z=8$, 17942 reflections measured, 4227 unique $\left(R_{\text {int }}=0.0252\right), 3653>2 \sigma(F), R=0.0749$ (observed), $R_{w}=0.2035$ (all data).
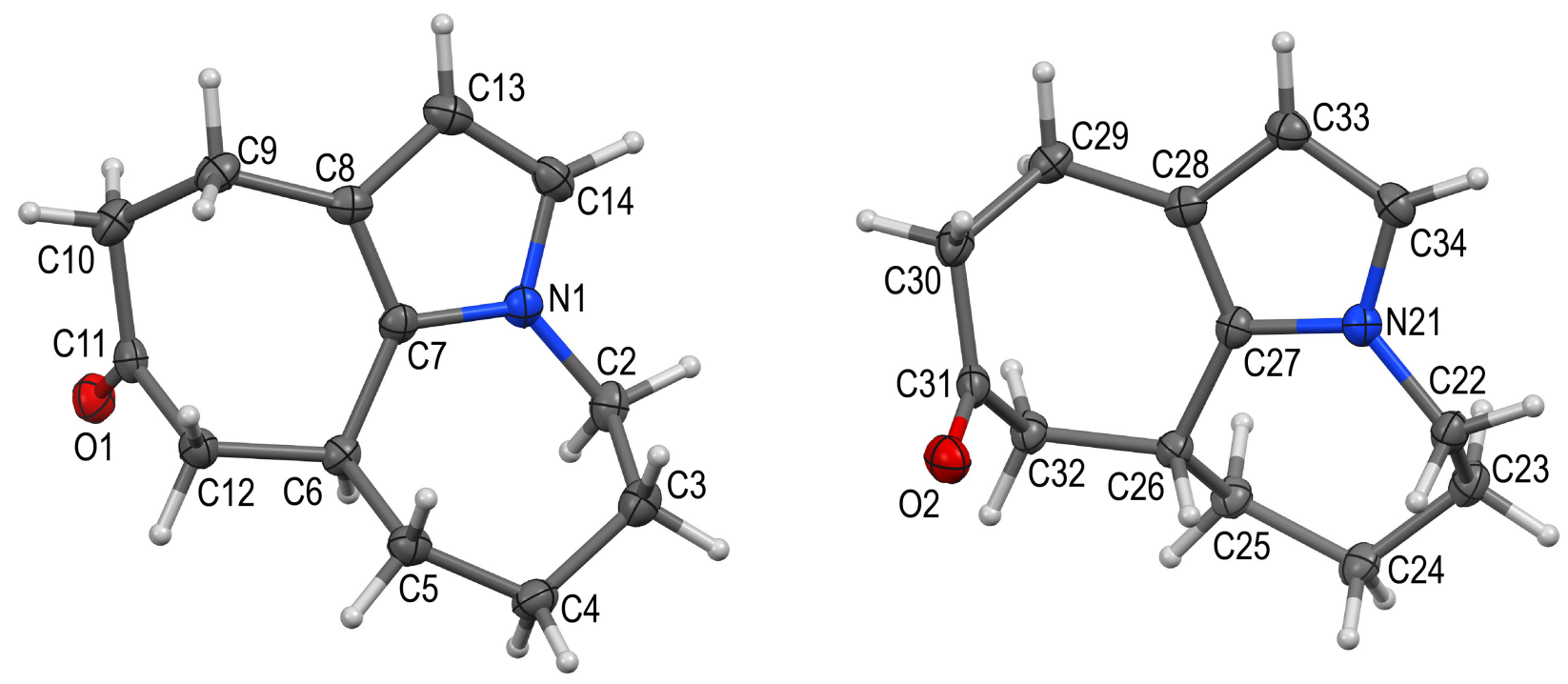

Figure S3. Structural representation of tricyclic pyrrole S9 (asymmetric unit contains both enantiomers). Displacement ellipsoids are shown at $50 \%$ probability. 


\section{Computational Details}

Gaussian $16^{10}$ was used to fully optimize all the structures reported in this paper at the M06-2X level ${ }^{11}$ of density functional theory (DFT) using the SMD solvation model ${ }^{12}$ in dichloromethane. The $6-31 \mathrm{G}(\mathrm{d})$ basis set $^{13}$ was chosen for all atoms. Frequency calculations were carried out at the same level of theory as those for the structural optimization. Transition structures were located using the Berny algorithm and intrinsic reaction coordinate (IRC) calculations ${ }^{14}$ were used to confirm the connectivity between transition structures and minima. To further refine the energies obtained from the SMD/M06-2X/6-31G(d) calculations and to consider dispersive interactions, ${ }^{15}$ we carried out single-point energy calculations using the M06-2X-D3 functional method for all of the structures with a larger basis set def2-TZVP ${ }^{16}$ and the SMD solvation model in dichloromethane. All thermodynamic data were calculated at the standard (298.15 K and 1 atm) or nonstandard $(273.15 \mathrm{~K}$ and $1 \mathrm{~atm})$ states depending on the applied reaction conditions. In this work, the free energy for each species optimized by SMD/M06-2X/6-31g(d) in solution was calculated using the formula:

$$
\begin{gathered}
G=E(S M D / M 06-2 X-D 3 / d e f 2-T Z V P)+G(S M D / M 06-2 X-D 3 / 6-31 g(d))-E(S M D / M 06-2 X-D 3 / 6- \\
31 \mathrm{~g}(\mathrm{~d}))+\Delta G^{1 \mathrm{~atm} \rightarrow 1 M}
\end{gathered}
$$

where $\Delta G^{1 \mathrm{~atm} \rightarrow 1 \mathrm{M}}=1.89 \mathrm{kcal} / \mathrm{mol}$ is the free energy change for compression of $1 \mathrm{~mol}$ of an ideal gas from $1 \mathrm{~atm}$ to $1 \mathrm{M}$ solution phase standard state. ${ }^{17}$ In short, a correction of -1.89 (or 1.89) $\mathrm{kcal} / \mathrm{mol}$ is employed to estimate relative free energies for a 2-to-1 (or a 1-to-2) transformation.

10. Gaussian 16, Revision C.01, Frisch, M. J.; Trucks, G. W.; Schlegel, H. B.; Scuseria, G. E.; Robb, M. A.; Cheeseman, J. R.; Scalmani, G.; Barone, V.; Petersson, G. A.; Nakatsuji, H.; Li, X.; Caricato, M.; Marenich, A. V.; Bloino, J.; Janesko, B. G.; Gomperts, R.; Mennucci, B.; Hratchian, H. P.; Ortiz, J. V.; Izmaylov, A. F.; Sonnenberg, J. L.; Williams-Young, D.; Ding, F.; Lipparini, F.; Egidi, F.; Goings, J.; Peng, B.; Petrone, A.; Henderson, T.; Ranasinghe, D.; Zakrzewski, V. G.; Gao, J.; Rega, N.; Zheng, G.; Liang, W.; Hada, M.; Ehara, M.; Toyota, K.; Fukuda, R.; Hasegawa, J.; Ishida, M.; Nakajima, T.; Honda, Y.; Kitao, O.; Nakai, H.; Vreven, T.; Throssell, K.; Montgomery, J. A., Jr.; Peralta, J. E.; Ogliaro, F.; Bearpark, M. J.; Heyd, J. J.; Brothers, E. N.; Kudin, K. N.; Staroverov, V. N.; Keith, T. A.; Kobayashi, R.; Normand, J.; Raghavachari, K.; Rendell, A. P.; Burant, J. C.; lyengar, S. S.; Tomasi, J.; Cossi, M.; Millam, J. M.; Klene, M.; Adamo, C.; Cammi, R.; Ochterski, J. W.; Martin, R. L.; Morokuma, K.; Farkas, O.; Foresman, J. B.; Fox, D. J. Gaussian, Inc., Wallingford CT, 2016.

11. Zhao, Y.; Truhlar, D. G. Acc. Chem. Res. 2008, 41, 157.

12. Marenich, A. V.; Cramer, C. J.; Truhlar, D. G. J. Phys. Chem. B. 2009, 113, 6378.

13. Hariharan, P. C.; Pople, J. A. Theor. Chim. Acta. 1973, 28, 213.

14. (a) Fukui, K. J. Phys. Chem. 1970,74, 4161. (b) Fukui, K. Acc. Chem. Res. 1981, 14, 363.

15. Grimme, S.; Antony, J.; Ehrlich, S.; Krieg, H. J. Chem. Phys. 2010, 132, 154104.

16. Weigend, F.; Furche, F.; Ahlrichs, R. J. Chem. Phys. 2003, 119, 12753.

17. Ochterski, J. W. Thermochemistry, Gaussian, Inc., Wallingford, CT, 2000. 


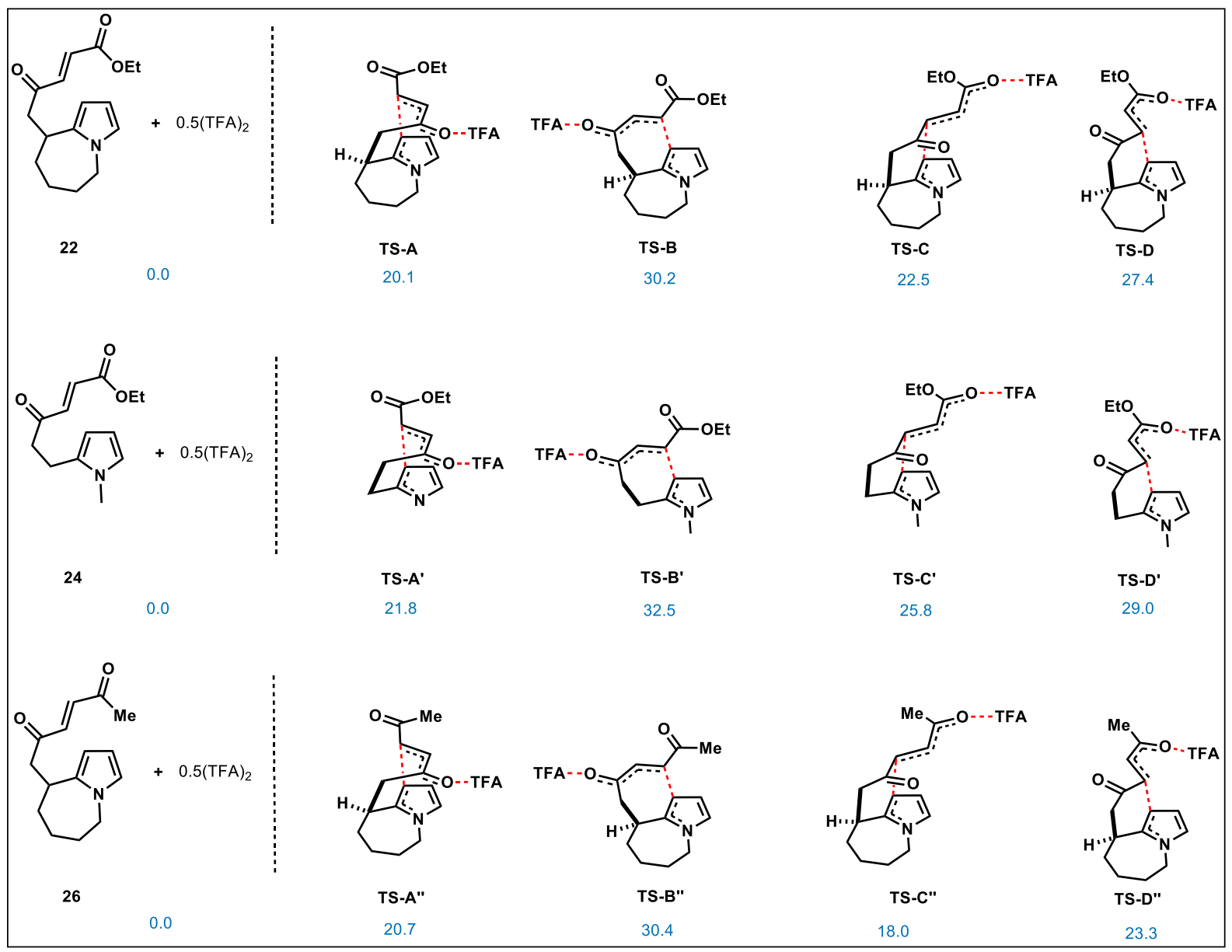

Figure S4. Calculated relative energies $(\mathrm{kcal} / \mathrm{mol})$ of Michael addition transition structures for substrates 22, 24, and 26.

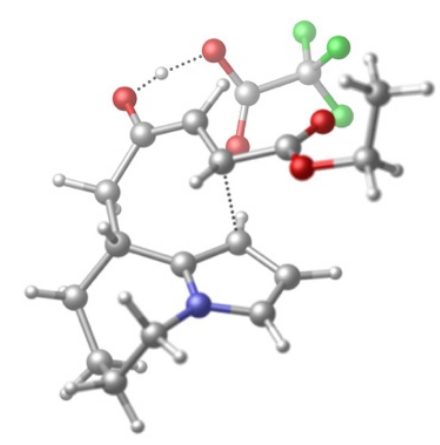

TS-A

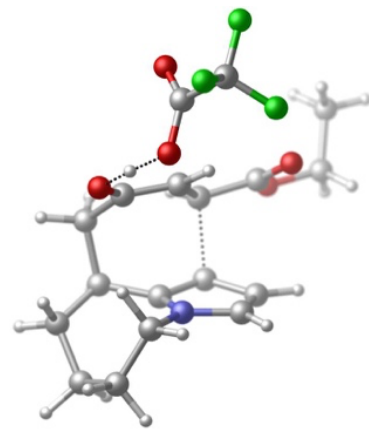

TS-B

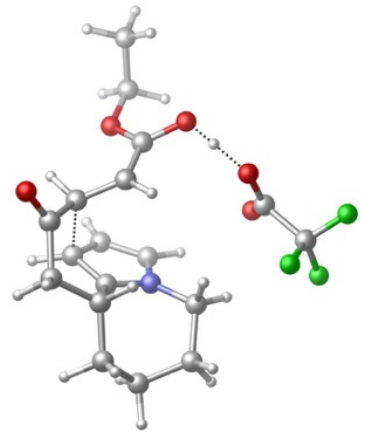

TS-C

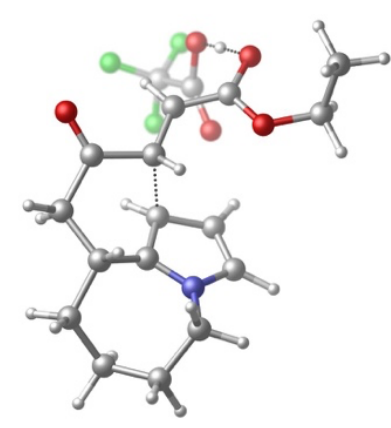

TS-D

Figure S5. Optimized geometries for transition structures TS-A, TS-B, TS-C, and TS-D. 


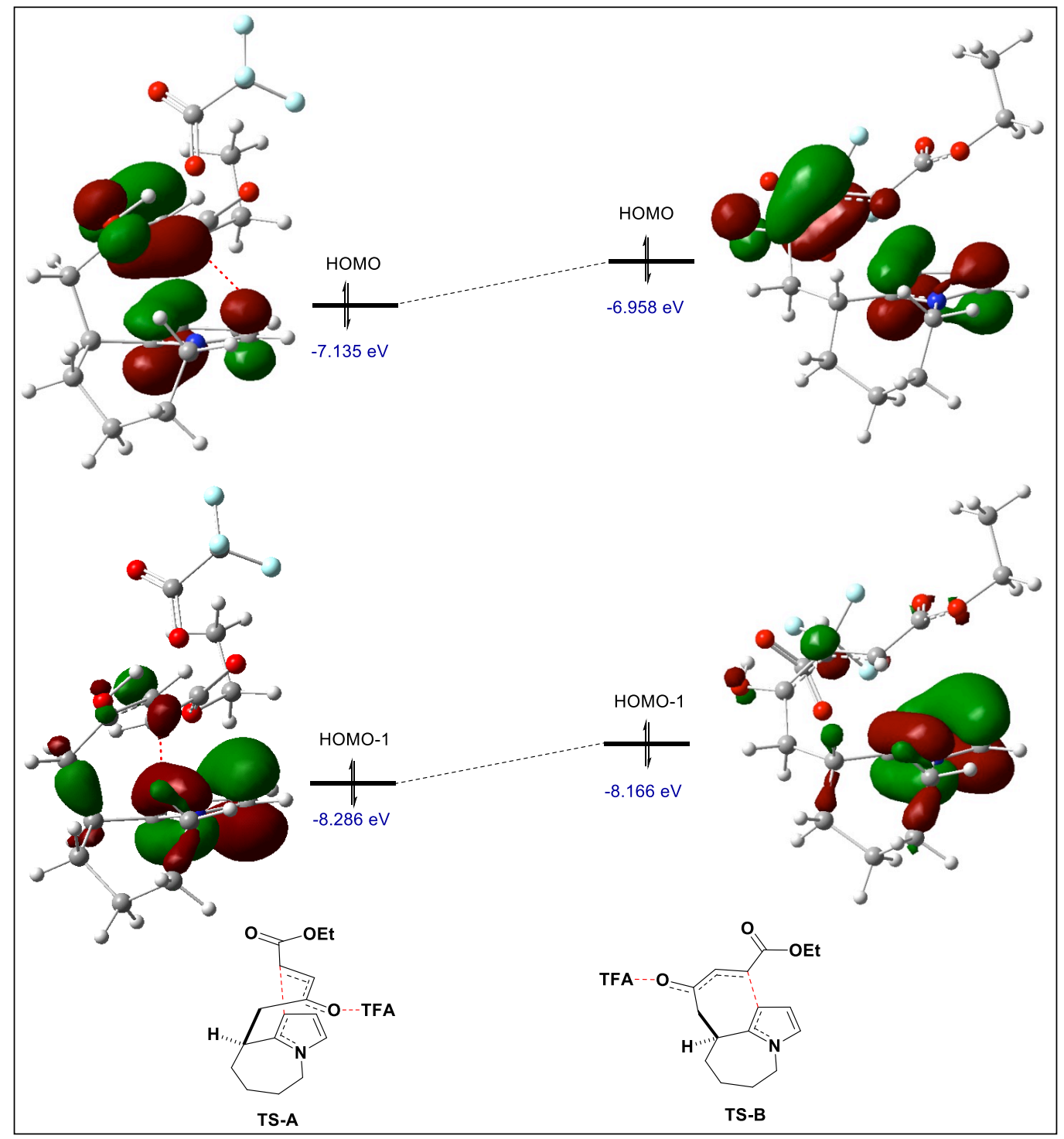

Figure S6. Spatial plots of the HOMO and HOMO-1 orbitals of transition structures TS-A and TS-B. The stabilization of the HOMO and HOMO-1 orbitals upon moving from TS-B to TS-A can be explained in terms of the secondary orbital interactions shown by a dashed red line. These stabilizing interactions are absent in TS-B due to the large distance between the relevant orbitals
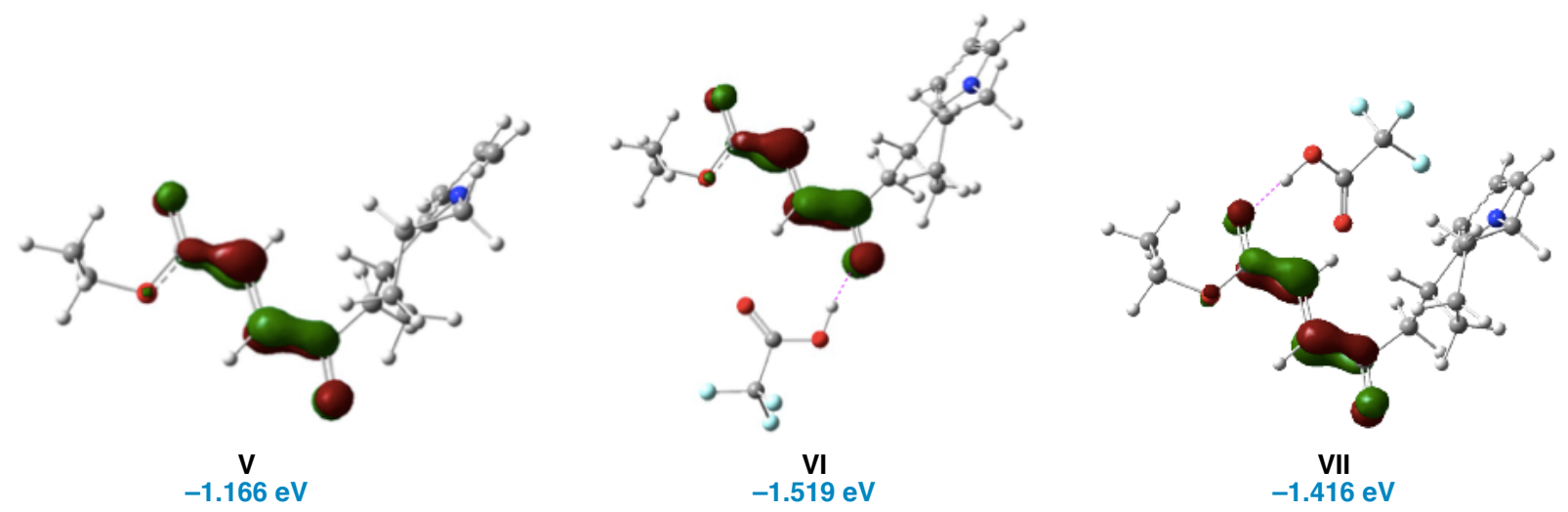

Figure S7. Gaussview illustrations of the LUMOs for substrate $22(\mathbf{V})$, and LUMOs for keto- and esterbound TFA adducts of substrate 22 (VI and VII, respectively). 

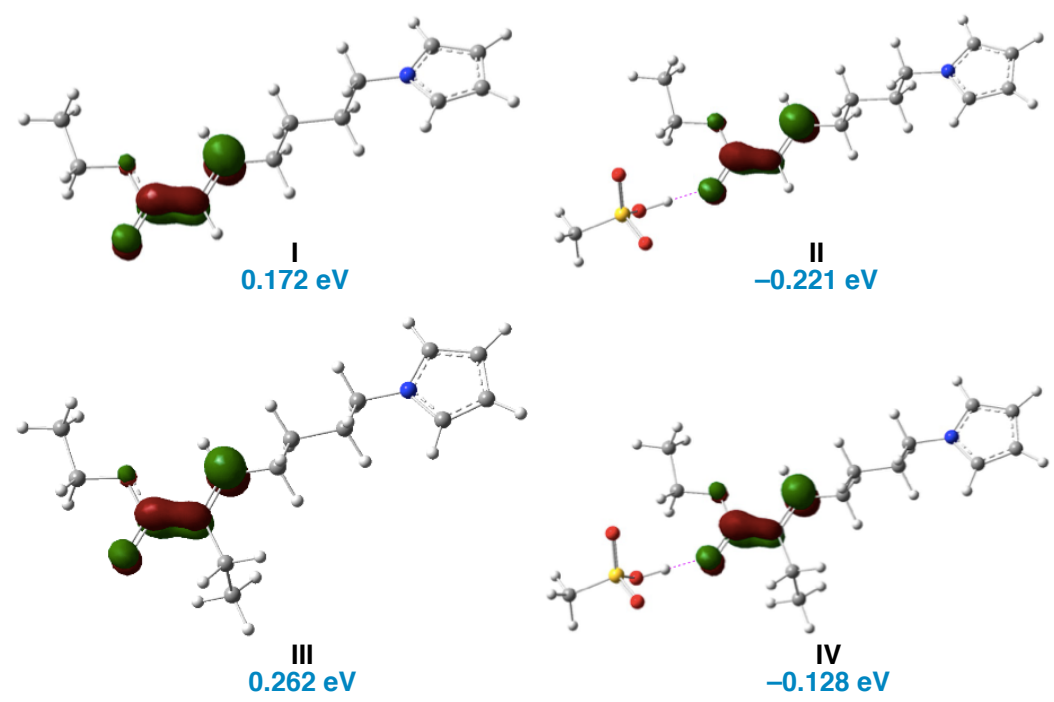

Figure S8. Gaussview illustrations of the LUMOs for substrates $\mathbf{5}$ and $\mathbf{8}$ (I and III, respectively), and LUMOs for ester-bound MsOH adducts of substrates $\mathbf{5}$ and $\mathbf{8}$ (II and IV, respectively).

Table S4.Total potential $(E)$ and Gibbs free energies $(G)$ of all structures optimized at the SMD/M06-2X/6-31G(d) level of theory along with the total potential energies calculated by SMD/M06-2X-D3/def2-TZVP// SMD/M06-2X/6-31G(d) for all the calculated structures.

$(\mathrm{MsOH})_{2}$

$E(S M D / M 06-2 X / 6-31 \mathrm{~g}(\mathrm{~d}))=-1328.362355 \mathrm{au}$

$\mathrm{G}(\mathrm{SMD} / \mathrm{M06}-2 \mathrm{X} / 6-31 \mathrm{~g}(\mathrm{~d}))=-1328.26875$ au $\left(0^{\circ} \mathrm{C}, 1 \mathrm{~atm}\right)$

$\mathrm{G}(\mathrm{SMD} / \mathrm{M06}-2 \mathrm{X} / 6-31 \mathrm{~g}(\mathrm{~d}))=-1328.273006$ au $\left(25^{\circ} \mathrm{C}, 1 \mathrm{~atm}\right)$

$\mathrm{E}(\mathrm{SMD} / \mathrm{M06}-2 \mathrm{X}-\mathrm{D} 3 / \mathrm{def} 2-\mathrm{TZVP} / / \mathrm{SMD} / \mathrm{M06}-2 \mathrm{X} / 6-31 \mathrm{~g}(\mathrm{~d}))=-1328.787227 \mathrm{au}$

$\begin{array}{lrrr}\mathrm{O} & 3.31966400 & -0.68248200 & -0.25901700 \\ \mathrm{~S} & 2.00154100 & -0.11706100 & -0.08828800 \\ \mathrm{O} & 0.98623800 & -0.41458400 & -1.11212600 \\ \mathrm{O} & 1.45937800 & -0.63571400 & 1.31106400 \\ \mathrm{C} & 2.08015900 & 1.63599000 & 0.12026200 \\ \mathrm{O} & -1.45967300 & 0.63504500 & -1.31150600 \\ \mathrm{O} & -0.98589500 & 0.41525800 & 1.11153000 \\ \mathrm{H} & -0.50075700 & 0.37668100 & -1.39610100 \\ \mathrm{H} & 0.50058700 & -0.37710400 & 1.39604600 \\ \mathrm{~S} & -2.00154600 & 0.11711500 & 0.08826000 \\ \mathrm{C} & -2.08016700 & -1.63605000 & -0.11938800 \\ \mathrm{O} & -3.31966600 & 0.68250100 & 0.25907000 \\ \mathrm{H} & 2.44452600 & 2.06465300 & -0.81595400 \\ \mathrm{H} & 1.07602900 & 2.00297900 & 0.34589100 \\ \mathrm{H} & 2.76873600 & 1.85416200 & 0.93815000 \\ \mathrm{H} & -1.07615100 & -2.00315700 & -0.34533100 \\ \mathrm{H} & -2.44407600 & -2.06426600 & 0.81721500 \\ \mathrm{H} & -2.76913300 & -1.85464300 & -0.93683500\end{array}$

5 (I)

$E(S M D / M 06-2 X / 6-31 g(d))=-711.7075912$ au 
$\mathrm{G}(\mathrm{SMD} / \mathrm{M} 06-2 \mathrm{X} / 6-31 \mathrm{~g}(\mathrm{~d}))=-711.445553 \mathrm{au}\left(0^{\circ} \mathrm{C}, 1 \mathrm{~atm}\right)$

$\mathrm{E}(\mathrm{SMD} / \mathrm{M}$ 06-2X -D3/def2-TZVP//SMD/M06-2X/6-31g(d)) = -711.9976103 au

$\begin{array}{lrrr}\text { C } & -5.11289200 & -0.71881600 & -0.81210800 \\ \text { C } & -6.35542800 & -0.61761800 & -0.22524800 \\ \text { C } & -6.34433600 & 0.55836700 & 0.57590000 \\ \text { C } & -5.09560800 & 1.12546100 & 0.44397000 \\ \text { H } & -4.69972100 & -1.45415600 & -1.48902700 \\ \text { H } & -7.17996900 & -1.30331800 & -0.36516000 \\ \text { H } & -7.15882600 & 0.95010200 & 1.16985900 \\ \text { H } & -4.66685200 & 2.01908100 & 0.87676900 \\ \text { N } & -4.35683300 & 0.34760800 & -0.40620300 \\ \mathrm{C} & -2.95165500 & 0.55268200 & -0.72560500 \\ \text { H } & -2.77784900 & 0.16874700 & -1.73563900 \\ \text { H } & -2.76516000 & 1.63104100 & -0.74316700 \\ \mathrm{C} & -2.02134200 & -0.13231200 & 0.27270800 \\ \text { H } & -2.23945500 & -1.20763300 & 0.28342100 \\ \text { H } & -2.23428300 & 0.24988400 & 1.27906000 \\ \mathrm{C} & -0.55254700 & 0.09911900 & -0.07167300 \\ \mathrm{H} & -0.34561400 & -0.27203600 & -1.08345400 \\ \mathrm{H} & -0.34139300 & 1.17657000 & -0.08069300 \\ \mathrm{C} & 1.82561000 & -0.32172500 & 0.60862200 \\ \mathrm{H} & 2.13791600 & 0.72207600 & 0.62120000 \\ \mathrm{C} & 2.72349100 & -1.26107200 & 0.29943900 \\ \mathrm{C} & 4.13868800 & -0.97804900 & -0.02365700 \\ \mathrm{O} & 4.94708900 & -1.84112800 & -0.29669900 \\ \mathrm{O} & 4.44547000 & 0.32647300 & 0.01377500 \\ \mathrm{C} & 5.80990300 & 0.65689200 & -0.29101900 \\ \mathrm{H} & 6.46487700 & 0.14650000 & 0.42140200 \\ \mathrm{H} & 6.04743400 & 0.28817900 & -1.29327600 \\ \mathrm{C} & 5.93985400 & 2.16000600 & -0.19841900 \\ \mathrm{H} & 5.69315800 & 2.50872800 & 0.80838200 \\ \mathrm{H} & 6.96814100 & 2.45503600 & -0.42526900 \\ \mathrm{H} & 5.27264300 & 2.65073400 & -0.91264400 \\ \mathrm{C} & 0.38837800 & -0.59503500 & 0.92209700 \\ \mathrm{H} & 0.20178000 & -1.67503200 & 0.92269300 \\ \mathrm{H} & 0.16727800 & -0.22283800 & 1.93185900 \\ \mathrm{H} & 2.46055400 & -2.31507600 & 0.27046000 \\ & & & \end{array}$

5.MsOH (II)

$E(S M D / M 06-2 X / 6-31 g(d))=-1375.893803$ au

$\mathrm{G}(\mathrm{SMD} / \mathrm{M} 06-2 \mathrm{X} / 6-31 \mathrm{~g}(\mathrm{~d}))=-1375.578211 \mathrm{au}\left(0^{\circ} \mathrm{C}, 1 \mathrm{~atm}\right)$

$\mathrm{E}(\mathrm{SMD} / \mathrm{M}$ 06-2X -D3/def2-TZVP//SMD/M06-2X/6-31g(d)) $=-1376.395064 \mathrm{au}$

$\begin{array}{lrrr}\mathrm{C} & -7.08610300 & -1.66617700 & -0.33172000 \\ \mathrm{C} & -8.41479200 & -1.54107300 & 0.01051000 \\ \mathrm{C} & -8.73786500 & -0.15755800 & -0.06904600 \\ \mathrm{C} & -7.59259600 & 0.50347800 & -0.45619300 \\ \mathrm{H} & -6.44435600 & -2.53403600 & -0.40007500 \\ \mathrm{H} & -9.07999000 & -2.35161600 & 0.27533100 \\ \mathrm{H} & -9.69906300 & 0.29945800 & 0.12300700 \\ \mathrm{H} & -7.39851600 & 1.55213900 & -0.63588600 \\ \mathrm{~N} & -6.59654900 & -0.42099900 & -0.62059200 \\ \mathrm{C} & -5.20774400 & -0.11600400 & -0.93120200 \\ \mathrm{H} & -4.79895200 & -0.95521900 & -1.50252900\end{array}$

S-22 


$\begin{array}{lrrr}\mathrm{H} & -5.19510700 & 0.76534200 & -1.57998600 \\ \mathrm{C} & -4.37136900 & 0.13209300 & 0.32195900 \\ \mathrm{H} & -4.42506600 & -0.75365500 & 0.96727000 \\ \mathrm{H} & -4.80765800 & 0.96774600 & 0.88354600 \\ \mathrm{C} & -2.91615700 & 0.43751300 & -0.02266300 \\ \mathrm{H} & -2.48722600 & -0.39760400 & -0.59057600 \\ \mathrm{H} & -2.86758800 & 1.32103800 & -0.67253400 \\ \mathrm{C} & -0.65113400 & 1.00653000 & 0.88279700 \\ \mathrm{H} & -0.48957100 & 1.89105400 & 0.26729600 \\ \mathrm{C} & 0.40328900 & 0.27243600 & 1.25241800 \\ \mathrm{C} & 1.78773800 & 0.59577900 & 0.87290300 \\ \mathrm{O} & 2.73236600 & -0.10452700 & 1.22568100 \\ \mathrm{O} & 1.92008700 & 1.68582000 & 0.13450300 \\ \mathrm{C} & 3.25393500 & 2.04187000 & -0.28710500 \\ \mathrm{H} & 3.87541400 & 2.17955300 & 0.60321200 \\ \mathrm{H} & 3.66407900 & 1.22004400 & -0.88182600 \\ \mathrm{C} & 3.13975900 & 3.31565100 & -1.09070500 \\ \mathrm{H} & 2.71737600 & 4.12103000 & -0.48365400 \\ \mathrm{H} & 4.13339600 & 3.62001100 & -1.43035300 \\ \mathrm{H} & 2.50501400 & 3.16283800 & -1.96769400 \\ \mathrm{C} & -2.06742400 & 0.68164100 & 1.23291700 \\ \mathrm{H} & -2.10181100 & -0.19713900 & 1.88646900 \\ \mathrm{H} & -2.49801600 & 1.52518900 & 1.78935100 \\ \mathrm{O} & 5.13291300 & -0.61283600 & -1.60007000 \\ \mathrm{~S} & 5.58069800 & -1.21732800 & -0.35060100 \\ \mathrm{O} & 5.32632900 & -0.20105400 & 0.84789800 \\ \mathrm{O} & 5.04695700 & -2.52630200 & -0.00321600 \\ \mathrm{C} & 7.34671500 & -1.24655500 & -0.30046500 \\ \mathrm{H} & 7.71954200 & -0.23477200 & -0.46571300 \\ \mathrm{H} & 7.66475300 & -1.62899900 & 0.67037900 \\ \mathrm{H} & 7.67929000 & -1.91096600 & -1.10065300 \\ \mathrm{H} & 4.33319200 & -0.10253600 & 0.99410500 \\ \mathrm{H} & 0.29882200 & -0.62120700 & 1.86047500\end{array}$

\begin{tabular}{|c|c|c|c|}
\hline \multicolumn{4}{|c|}{8 (III) } \\
\hline \multicolumn{4}{|c|}{$E(S M D / M 06-2 X / 6-31 g(d))=-790.2978018 \mathrm{au}$} \\
\hline \multicolumn{4}{|c|}{$\mathrm{G}(\mathrm{SMD} / \mathrm{M} 06-2 \mathrm{X} / 6-31 \mathrm{~g}(\mathrm{~d}))=-789.981527 \mathrm{au}\left(0^{\circ} \mathrm{C}, 1 \mathrm{~atm}\right)$} \\
\hline \multicolumn{4}{|c|}{$\mathrm{E}(\mathrm{SMD} / \mathrm{M} 06-2 \mathrm{X}-\mathrm{D} 3 / \mathrm{def} 2-T Z V P / / S M D / M 06-2 \mathrm{X} / 6-31 \mathrm{~g}(\mathrm{~d}))=-790.616225 \mathrm{au}$} \\
\hline C & 5.40233600 & 0.63823600 & -0.75126000 \\
\hline C & 6.63751200 & 0.55170600 & -0.14660500 \\
\hline C & 6.64999400 & -0.65555700 & 0.60655500 \\
\hline C & 5.42185200 & -1.25480200 & 0.43000200 \\
\hline $\mathrm{H}$ & 4.97792400 & 1.38715700 & -1.40584600 \\
\hline $\mathrm{H}$ & 7.44246300 & 1.26723700 & -0.24451100 \\
\hline $\mathrm{H}$ & 7.46631300 & -1.04575800 & 1.19889100 \\
\hline $\mathrm{H}$ & 5.01446600 & -2.17789300 & 0.81918300 \\
\hline $\mathrm{N}$ & 4.67335800 & -0.46632700 & -0.40162700 \\
\hline C & 3.28057200 & -0.70056000 & -0.75363600 \\
\hline $\mathrm{H}$ & 3.11120800 & -0.27971900 & -1.74964000 \\
\hline $\mathrm{H}$ & 3.12787300 & -1.78233000 & -0.81957500 \\
\hline C & 2.31298000 & -0.08676700 & 0.25555400 \\
\hline $\mathrm{H}$ & 2.50044200 & 0.99262000 & 0.31811700 \\
\hline $\mathrm{H}$ & 2.51798300 & -0.50763300 & 1.24801200 \\
\hline & & & S-23 \\
\hline
\end{tabular}




$\begin{array}{lrrr}\mathrm{C} & 0.85796200 & -0.34230300 & -0.12792200 \\ \mathrm{H} & 0.65833200 & 0.06987000 & -1.12559400 \\ \mathrm{H} & 0.67707100 & -1.42337000 & -0.19203500 \\ \mathrm{C} & -1.54416700 & -0.04975400 & 0.52886700 \\ \mathrm{H} & -1.84912100 & -1.07670600 & 0.71994700 \\ \mathrm{C} & -2.44110800 & 0.78494000 & -0.01659300 \\ \mathrm{C} & -3.83056100 & 0.31570900 & -0.29347000 \\ \mathrm{O} & -4.69661300 & 1.03043600 & -0.75659900 \\ \mathrm{O} & -4.04666000 & -0.97005300 & 0.01638400 \\ \mathrm{C} & -5.37415700 & -1.45934800 & -0.23110500 \\ \mathrm{H} & -6.08557800 & -0.85685400 & 0.34139100 \\ \mathrm{H} & -5.60455100 & -1.33583600 & -1.29345000 \\ \mathrm{C} & -5.40184400 & -2.91200200 & 0.18608900 \\ \mathrm{H} & -5.16345400 & -3.01410300 & 1.24858200 \\ \mathrm{H} & -6.39927400 & -3.32573200 & 0.01329100 \\ \mathrm{H} & -4.67956500 & -3.49470700 & -0.39263200 \\ \mathrm{C} & -0.12383600 & 0.27987800 & 0.87626200 \\ \mathrm{H} & 0.03588600 & 1.36178400 & 0.92219800 \\ \mathrm{H} & 0.09526300 & -0.12014300 & 1.87458300 \\ \mathrm{C} & -2.19600200 & 2.23667700 & -0.34421300 \\ \mathrm{H} & -1.12966300 & 2.40511500 & -0.51821300 \\ \mathrm{H} & -2.71718900 & 2.47627900 & -1.27594600 \\ \mathrm{C} & -2.69846100 & 3.16504700 & 0.76569500 \\ \mathrm{H} & -3.76785700 & 3.00999900 & 0.93908000 \\ \mathrm{H} & -2.16930200 & 2.97037900 & 1.70450800 \\ \mathrm{H} & -2.54543100 & 4.21497900 & 0.49745600\end{array}$

\section{MsOH (IV)}

$\mathrm{E}(\mathrm{SMD} / \mathrm{M} 06-2 \mathrm{X} / 6-31 \mathrm{~g}(\mathrm{~d}))=-1454.483847 \mathrm{au}$

$\mathrm{G}(\mathrm{SMD} / \mathrm{M06}-2 \mathrm{X} / 6-31 \mathrm{~g}(\mathrm{~d}))=-1454.109618$ au $\left(0^{\circ} \mathrm{C}, 1 \mathrm{~atm}\right)$

E(SMD/M06-2X -D3/def2-TZVP//SMD/M06-2X/6-31g(d)) = -1455.013932 au

$\begin{array}{lrrr}\mathrm{C} & -7.24904900 & -1.19863700 & -0.97187500 \\ \mathrm{C} & -8.57573600 & -1.02847900 & -0.64098200 \\ \mathrm{C} & -8.76703500 & 0.35775600 & -0.38247100 \\ \mathrm{C} & -7.54880100 & 0.97483900 & -0.56519100 \\ \mathrm{H} & -6.68675000 & -2.08312400 & -1.23866800 \\ \mathrm{H} & -9.32403300 & -1.80828700 & -0.60132400 \\ \mathrm{H} & -9.69067500 & 0.84804000 & -0.10649400 \\ \mathrm{H} & -7.25129000 & 2.01061900 & -0.47378100 \\ \mathrm{~N} & -6.63467700 & 0.02386500 & -0.93061700 \\ \mathrm{C} & -5.21040900 & 0.25671500 & -1.11926800 \\ \mathrm{H} & -4.84706300 & -0.46455100 & -1.85782600 \\ \mathrm{H} & -5.08745500 & 1.25792400 & -1.54398800 \\ \mathrm{C} & -4.42234200 & 0.12960000 & 0.18234200 \\ \mathrm{H} & -4.57287000 & -0.87653400 & 0.59364600 \\ \mathrm{H} & -4.82538900 & 0.84091200 & 0.91418700 \\ \mathrm{C} & -2.93347000 & 0.38980900 & -0.03008500 \\ \mathrm{H} & -2.53523500 & -0.30886000 & -0.77712800 \\ \mathrm{H} & -2.78896300 & 1.40014700 & -0.43444500 \\ \mathrm{C} & -0.69033800 & 0.59334200 & 1.06590800 \\ \mathrm{H} & -0.47598700 & 1.65415300 & 0.95196400 \\ \mathrm{C} & 0.33004400 & -0.27447400 & 0.97858200 \\ \mathrm{C} & 1.71176600 & 0.23795200 & 0.79373200\end{array}$




$\begin{array}{lrrr}\mathrm{O} & 2.68036100 & -0.51637900 & 0.75420900 \\ \mathrm{O} & 1.81636900 & 1.55254100 & 0.68437700 \\ \mathrm{C} & 3.13950000 & 2.09991100 & 0.50534200 \\ \mathrm{H} & 3.75527500 & 1.80693800 & 1.36147800 \\ \mathrm{H} & 3.57502900 & 1.67748400 & -0.40515800 \\ \mathrm{C} & 2.98928100 & 3.60004500 & 0.41296100 \\ \mathrm{H} & 2.54302400 & 4.00263200 & 1.32633800 \\ \mathrm{H} & 3.97394900 & 4.05509700 & 0.27628100 \\ \mathrm{H} & 2.36001100 & 3.87276400 & -0.43854800 \\ \mathrm{C} & -2.13104800 & 0.24116900 & 1.27193500 \\ \mathrm{H} & -2.24264400 & -0.77689600 & 1.65770300 \\ \mathrm{H} & -2.55229000 & 0.92056200 & 2.02370500 \\ \mathrm{O} & 5.21512700 & 0.55990000 & -1.83669500 \\ \mathrm{~S} & 5.62702800 & -0.59902300 & -1.05326000 \\ \mathrm{O} & 5.28706400 & -0.34744800 & 0.48137800 \\ \mathrm{O} & 5.12153200 & -1.90278700 & -1.45792000 \\ \mathrm{C} & 7.38915300 & -0.63783800 & -0.92802600 \\ \mathrm{H} & 7.73384000 & 0.31812300 & -0.53115200 \\ \mathrm{H} & 7.67759900 & -1.46245100 & -0.27469000 \\ \mathrm{H} & 7.77864300 & -0.79457900 & -1.93607900 \\ \mathrm{C} & 0.21761800 & -1.77272200 & 1.11342400 \\ \mathrm{H} & -0.78762700 & -2.09270300 & 0.82627100 \\ \mathrm{H} & 0.91599300 & -2.24188800 & 0.41413700 \\ \mathrm{C} & 0.53088700 & -2.24464300 & 2.53651800 \\ \mathrm{H} & 1.53838500 & -1.93581000 & 2.83216600 \\ \mathrm{H} & -0.17973300 & -1.81822000 & 3.25231200 \\ \mathrm{H} & 0.47553900 & -3.33520800 & 2.60635300 \\ \mathrm{H} & 4.28725200 & -0.36165200 & 0.60934600\end{array}$

$\mathrm{TS}_{5-6}$

$E(S M D / M 06-2 X / 6-31 g(d))=-2040.06886$ au

$\mathrm{G}(\mathrm{SMD} / \mathrm{M06}-2 \mathrm{X} / 6-31 \mathrm{~g}(\mathrm{~d}))=-2039.686283 \mathrm{au}\left(0^{\circ} \mathrm{C}, 1 \mathrm{~atm}\right)$

E (SMD/M06-2X -D3/def2-TZVP//SMD/M06-2X/6-31g(d)) = -2040.77725 au

$\begin{array}{lrrr}\mathrm{O} & -1.25325700 & 1.30623000 & -0.62164200 \\ \mathrm{H} & 2.04882300 & 2.08592300 & -0.33314200 \\ \mathrm{C} & 2.94338400 & -2.17313200 & 1.38402500 \\ \mathrm{C} & 2.76564100 & -0.99812200 & 2.08100500 \\ \mathrm{C} & 1.38825200 & -0.69082400 & 2.01461700 \\ \mathrm{H} & 3.87314800 & -2.69204500 & 1.19141900 \\ \mathrm{H} & 3.51719900 & -0.39157900 & 2.56779500 \\ \mathrm{C} & -0.70383400 & -1.66968100 & 1.12572000 \\ \mathrm{H} & -1.19313700 & -2.00180700 & 2.04633200 \\ \mathrm{C} & 0.78447200 & -2.44242400 & -1.78257500 \\ \mathrm{C} & 1.88698400 & -1.72960900 & -1.02112500 \\ \mathrm{H} & 2.87271000 & -2.14325100 & -1.21858800 \\ \mathrm{C} & 1.83460500 & -0.32121600 & -0.88955000 \\ \mathrm{C} & 2.97040000 & 0.41960900 & -0.60966900 \\ \mathrm{O} & 2.98544400 & 1.70894300 & -0.38203600 \\ \mathrm{O} & 4.14860200 & -0.17792000 & -0.59805900 \\ \mathrm{C} & 5.30480400 & 0.55057900 & -0.13298700 \\ \mathrm{H} & 5.01861500 & 1.17355600 & 0.71698100 \\ \mathrm{H} & 5.98484000 & -0.23053900 & 0.21122500 \\ \mathrm{C} & 5.92220800 & 1.36615700 & -1.24999900\end{array}$

S-25 


$\begin{array}{lrrr}\mathrm{H} & 6.84211600 & 1.83651400 & -0.88997600 \\ \mathrm{H} & 6.17215400 & 0.72321000 & -2.09865500 \\ \mathrm{H} & 5.23939300 & 2.15004300 & -1.58590000 \\ \mathrm{H} & -1.00481000 & -0.63446700 & 0.93778400 \\ \mathrm{H} & 0.84454900 & 0.16523200 & 2.39595900 \\ \mathrm{~N} & 0.74588900 & -1.66273500 & 1.36816000 \\ \mathrm{C} & 1.68836900 & -2.52766500 & 0.80600200 \\ \mathrm{H} & 1.38428800 & -3.52994300 & 0.53191600 \\ \mathrm{~S} & -0.61240700 & 2.32189500 & 0.28404200 \\ \mathrm{O} & -0.47669200 & 1.85157000 & 1.66793100 \\ \mathrm{O} & 0.65500800 & 2.81739000 & -0.32225400 \\ \mathrm{C} & -1.71074700 & 3.71753100 & 0.28551000 \\ \mathrm{H} & -1.27034500 & 4.50201200 & 0.90350400 \\ \mathrm{H} & -1.83574500 & 4.06470400 & -0.74165000 \\ \mathrm{H} & -2.66950700 & 3.40291300 & 0.70322200 \\ \mathrm{C} & -0.65919700 & -2.08589000 & -1.41882400 \\ \mathrm{H} & -0.82479500 & -1.00479700 & -1.50379600 \\ \mathrm{H} & -1.30630800 & -2.55118300 & -2.17003200 \\ \mathrm{C} & -1.12535100 & -2.55613900 & -0.03703800 \\ \mathrm{H} & -0.81999600 & -3.59556600 & 0.14103100 \\ \mathrm{H} & -2.21854500 & -2.54443000 & -0.02372600 \\ \mathrm{H} & 0.89077700 & 0.21141900 & -0.94617200 \\ \mathrm{H} & 0.95221900 & -2.19605600 & -2.84006100 \\ \mathrm{H} & 0.92679700 & -3.52587000 & -1.69432500 \\ \mathrm{H} & -2.74728800 & 1.17766600 & -0.58700800 \\ \mathrm{O} & -3.78076500 & 1.12053900 & -0.56429500 \\ \mathrm{~S} & -4.23888800 & -0.35251700 & -0.22117800 \\ \mathrm{O} & -3.94311700 & -1.23920900 & -1.34119500 \\ \mathrm{O} & -3.72689200 & -0.73779500 & 1.09023200 \\ \mathrm{C} & -5.98518600 & -0.08882100 & -0.12417300 \\ \mathrm{H} & -6.33889500 & 0.28109200 & -1.08768300 \\ \mathrm{H} & -6.44388500 & -1.05308600 & 0.10474200 \\ \mathrm{H} & -6.19033700 & 0.62932700 & 0.67077300\end{array}$

$\mathrm{TS}_{8-7}$

$E(S M D / M 06-2 X / 6-31 \mathrm{~g}(\mathrm{~d}))=-2118.644446$ au

$\mathrm{G}(\mathrm{SMD} / \mathrm{M06}-2 \mathrm{X} / 6-31 \mathrm{~g}(\mathrm{~d}))=-2118.20693$ au $\left(0^{\circ} \mathrm{C}, 1 \mathrm{~atm}\right)$

E (SMD/M06-2X -D3/def2-TZVP//SMD/M06-2X/6-31g(d)) = -2119.382956 au

$\begin{array}{lrrr}\mathrm{O} & -1.59538700 & -1.54376000 & 0.93837700 \\ \mathrm{H} & 1.75448100 & -2.00652600 & 0.78318300 \\ \mathrm{C} & 1.79789500 & 1.15286100 & -2.32999000 \\ \mathrm{C} & 0.98149600 & 0.05373500 & -2.15918500 \\ \mathrm{C} & -0.07295300 & 0.45469000 & -1.30816200 \\ \mathrm{H} & 2.71901000 & 1.21084800 & -2.89431200 \\ \mathrm{H} & 1.09401400 & -0.94291600 & -2.56300100 \\ \mathrm{C} & -0.90085500 & 2.54777400 & -0.25138500 \\ \mathrm{H} & -1.70459100 & 2.82137900 & -0.94118800 \\ \mathrm{C} & 2.16873900 & 3.20633300 & 0.93399200 \\ \mathrm{C} & 2.42111200 & 1.90312200 & 0.19034900 \\ \mathrm{H} & 3.36269900 & 1.95393500 & -0.34721500 \\ \mathrm{C} & 2.12718600 & 0.61428400 & 0.72215400 \\ \mathrm{C} & 2.82875000 & -0.45863500 & 0.17444000 \\ \mathrm{O} & 2.66301200 & -1.73063100 & 0.44792100\end{array}$

S-26 


$\begin{array}{lrrr}\mathrm{O} & 3.81336300 & -0.21208700 & -0.67751400 \\ \mathrm{C} & 4.37405900 & -1.29549500 & -1.44819100 \\ \mathrm{H} & 3.57774800 & -1.98928100 & -1.72475000 \\ \mathrm{H} & 4.75211400 & -0.80789700 & -2.34869400 \\ \mathrm{C} & 5.48906900 & -1.98600400 & -0.69044600 \\ \mathrm{H} & 5.95395200 & -2.73821600 & -1.33485500 \\ \mathrm{H} & 6.25517200 & -1.26291400 & -0.39628000 \\ \mathrm{H} & 5.10539700 & -2.48241700 & 0.20377000 \\ \mathrm{H} & -1.34410300 & 1.90328400 & 0.51308000 \\ \mathrm{H} & -0.91625000 & -0.11509400 & -0.94291000 \\ \mathrm{~N} & 0.06948700 & 1.74361500 & -1.00314100 \\ \mathrm{C} & 1.30946400 & 2.18421800 & -1.47934600 \\ \mathrm{H} & 1.47432100 & 3.24527100 & -1.61528500 \\ \mathrm{~S} & -0.79601100 & -2.69571700 & 0.39261100 \\ \mathrm{O} & -0.58508800 & -2.61181000 & -1.05664100 \\ \mathrm{O} & 0.45687400 & -2.86609400 & 1.18299800 \\ \mathrm{C} & -1.76480700 & -4.14658500 & 0.72529700 \\ \mathrm{H} & -1.20963100 & -5.02026000 & 0.37909500 \\ \mathrm{H} & -1.94427100 & -4.20853100 & 1.79990900 \\ \mathrm{H} & -2.71003600 & -4.06223100 & 0.18450100 \\ \mathrm{C} & 0.77183700 & 3.58899900 & 1.44246800 \\ \mathrm{H} & 0.40714500 & 2.88011200 & 2.19127900 \\ \mathrm{H} & 0.89871900 & 4.54057200 & 1.97137500 \\ \mathrm{C} & -0.30294300 & 3.80301100 & 0.37159600 \\ \mathrm{H} & 0.07469100 & 4.46983200 & -0.41361700 \\ \mathrm{H} & -1.14681400 & 4.32889600 & 0.83115500 \\ \mathrm{H} & 2.85486100 & 3.19224600 & 1.79248100 \\ \mathrm{H} & 2.52144200 & 4.01907800 & 0.28803800 \\ \mathrm{C} & 1.15205600 & 0.36105800 & 1.85247600 \\ \mathrm{H} & 0.24756500 & 0.95558000 & 1.70604700 \\ \mathrm{H} & 0.80088500 & -0.67212800 & 1.83634700 \\ \mathrm{C} & 1.75311600 & 0.64887700 & 3.23226800 \\ \mathrm{H} & 1.02124000 & 0.45382800 & 4.02307300 \\ \mathrm{H} & 2.62350600 & 0.00772400 & 3.40900200 \\ \mathrm{H} & 2.08178100 & 1.68918400 & 3.32603000 \\ \mathrm{H} & -2.97899400 & -1.31305800 & 0.45868000 \\ \mathrm{O} & -3.94993200 & -1.10718500 & 0.14590900 \\ \mathrm{~S} & -4.06498500 & 0.40160000 & -0.29770700 \\ \mathrm{O} & -3.20052800 & 0.64743400 & -1.44960600 \\ \mathrm{O} & -3.89679500 & 1.27909600 & 0.85617300 \\ \mathrm{H} & -5.75571800 & 0.41992900 & -0.81511700 \\ & -6.38678700 & 0.15705700 & 0.03500400 \\ \mathrm{H} & -5.97755600 & 1.43348000 & -1.15549700 \\ \mathrm{H} & & -0.29300600 & -1.63118200\end{array}$

\section{5}

$\mathrm{E}(\mathrm{SMD} / \mathrm{M06}-2 \mathrm{X} / 6-31 \mathrm{~g}(\mathrm{~d}))=-751.0041087 \mathrm{au}$

$\mathrm{G}(\mathrm{SMD} / \mathrm{M06}-2 \mathrm{X} / 6-31 \mathrm{~g}(\mathrm{~d}))=-750.72018$ au $\left(25^{\circ} \mathrm{C}, 1 \mathrm{~atm}\right)$

$\mathrm{E}(\mathrm{SMD} / \mathrm{M} 06-2 \mathrm{X}-\mathrm{D} 3 / \mathrm{def} 2-T Z V P / / S M D / M 06-2 \mathrm{X} / 6-31 \mathrm{~g}(\mathrm{~d}))=-751.307601 \mathrm{au}$
C
C
$\begin{array}{lll}-4.52808900 & -0.40946800 & 0.96799100\end{array}$
C
$\begin{array}{lll}-5.51725400 & 0.48553700 & 1.31216400\end{array}$
C
$\begin{array}{lll}-5.57838600 & 1.45948000 & 0.27647300\end{array}$
$-4.62303300 \quad 1.11868800 \quad-0.65578300$ 


$\begin{array}{lrrr}\mathrm{H} & -4.15818000 & -1.29351800 & 1.46925000 \\ \mathrm{H} & -6.13340000 & 0.43863300 & 2.19972600 \\ \mathrm{H} & -6.25005300 & 2.30490900 & 0.21578100 \\ \mathrm{H} & -4.33664700 & 1.58444700 & -1.58886400 \\ \mathrm{~N} & -3.99529000 & -0.02170900 & -0.23197200 \\ \mathrm{C} & -2.86059400 & -0.65033000 & -0.89025300 \\ \mathrm{H} & -2.92522500 & -1.72957100 & -0.71992000 \\ \mathrm{H} & -2.95907600 & -0.47610100 & -1.96621500 \\ \mathrm{C} & -1.52417900 & -0.11111200 & -0.38539100 \\ \mathrm{H} & -1.44491400 & -0.28980400 & 0.69351100 \\ \mathrm{H} & -1.49353400 & 0.97450200 & -0.53830700 \\ \mathrm{C} & -0.34582700 & -0.77704600 & -1.10880300 \\ \mathrm{H} & -0.38053300 & -1.85978800 & -0.95264100 \\ \mathrm{H} & -0.45286400 & -0.60378800 & -2.18792100 \\ \mathrm{C} & 0.96301100 & -0.20109000 & -0.66113600 \\ \mathrm{H} & 1.14677500 & 0.82955300 & -0.95808500 \\ \mathrm{C} & 1.89394900 & -0.82348400 & 0.07655400 \\ \mathrm{C} & 3.16648500 & -0.12310700 & 0.42146900 \\ \mathrm{O} & 4.07057000 & -0.64856400 & 1.03918400 \\ \mathrm{O} & 3.23085600 & 1.14254600 & -0.01377000 \\ \mathrm{C} & 4.44472000 & 1.84797200 & 0.29129200 \\ \mathrm{H} & 4.58280500 & 1.86100500 & 1.37644500 \\ \mathrm{H} & 5.28751400 & 1.30795000 & -0.15038000 \\ \mathrm{C} & 4.30862400 & 3.24238200 & -0.27600300 \\ \mathrm{H} & 3.45759100 & 3.76163300 & 0.17367900 \\ \mathrm{H} & 5.21559700 & 3.81547800 & -0.06421000 \\ \mathrm{H} & 4.16546000 & 3.20775000 & -1.35971100 \\ \mathrm{C} & 1.81524900 & -2.24834900 & 0.56514000 \\ \mathrm{H} & 2.26638100 & -2.30074600 & 1.56046200 \\ \mathrm{H} & 0.76972800 & -2.55135100 & 0.66829100 \\ \mathrm{C} & 2.54968900 & -3.21275400 & -0.37116000 \\ \mathrm{H} & 2.09737800 & -3.20650300 & -1.36853400 \\ \mathrm{H} & 3.59997500 & -2.92224900 & -0.47192200 \\ \mathrm{H} & 2.51464400 & -4.23626100 & 0.01475300 \\ & & & \\ & & & \\ & & & \end{array}$

$\mathrm{TS}_{15-16}$

$E(S M D / M 06-2 X / 6-31 \mathrm{~g}(\mathrm{~d}))=-2079.356425$ au

$\mathrm{G}(\mathrm{SMD} / \mathrm{M} 06-2 \mathrm{X} / 6-31 \mathrm{~g}(\mathrm{~d}))=-2078.955311 \mathrm{au}\left(25^{\circ} \mathrm{C}, 1 \mathrm{~atm}\right)$

E (SMD/M06-2X -D3/def2-TZVP//SMD/M06-2X/6-31g(d)) = -2080.078555 au

$\begin{array}{lrrr}\mathrm{C} & -0.07413900 & 1.59722600 & -1.17530900 \\ \mathrm{C} & -1.31183100 & 1.28804600 & -1.78945100 \\ \mathrm{C} & -1.88122700 & 2.48080000 & -2.22748800 \\ \mathrm{C} & -0.97212800 & 3.50281400 & -1.92804600 \\ \mathrm{H} & 0.78691400 & 0.94668300 & -1.07023900 \\ \mathrm{H} & -1.71754700 & 0.28595800 & -1.85854400 \\ \mathrm{H} & -2.84132800 & 2.61775000 & -2.70522700 \\ \mathrm{H} & -1.05123400 & 4.57333600 & -2.06811800 \\ \mathrm{~N} & 0.12554500 & 2.96562500 & -1.37289400 \\ \mathrm{C} & 1.20100100 & 3.69351500 & -0.71599900 \\ \mathrm{H} & 2.13243000 & 3.14922900 & -0.89785200 \\ \mathrm{H} & 1.27149800 & 4.68399100 & -1.16990200 \\ \mathrm{C} & 0.90706100 & 3.76991300 & 0.78078200 \\ \mathrm{C} & 0.70031700 & 2.37700800 & 1.36728000\end{array}$




\begin{tabular}{lrrr}
$\mathrm{C}$ & -0.51340200 & 1.63791700 & 0.84269800 \\
$\mathrm{H}$ & -1.37812700 & 2.26885400 & 0.63516000 \\
$\mathrm{C}$ & -0.78309400 & 0.32877100 & 1.32191400 \\
$\mathrm{C}$ & -2.04662900 & -0.19726100 & 1.09531400 \\
$\mathrm{O}$ & -2.41709100 & -1.41885000 & 1.43198800 \\
$\mathrm{O}$ & -2.97723300 & 0.55394300 & 0.53705900 \\
$\mathrm{C}$ & -4.17808700 & -0.07311800 & 0.03134600 \\
$\mathrm{H}$ & -4.50366300 & 0.59894500 & -0.76517900 \\
$\mathrm{H}$ & -3.91120300 & -1.03954100 & -0.39904000 \\
$\mathrm{C}$ & -5.22747100 & -0.18880800 & 1.11683300 \\
$\mathrm{H}$ & -5.43835500 & 0.79178000 & 1.55325500 \\
$\mathrm{H}$ & -6.15357200 & -0.58094400 & 0.68570000 \\
$\mathrm{H}$ & -4.89817000 & -0.86702500 & 1.90780900 \\
$\mathrm{H}$ & -1.69823100 & -2.08149800 & 1.20056900 \\
$\mathrm{H}$ & 0.56011100 & 2.45695300 & 2.45473000 \\
$\mathrm{H}$ & 1.60685600 & 1.78083800 & 1.21458600 \\
$\mathrm{H}$ & 1.74825300 & 4.25777900 & 1.28228800 \\
$\mathrm{H}$ & 0.01608400 & 4.38866200 & 0.94240700 \\
$\mathrm{O}$ & -0.67301000 & -3.03810800 & 0.31744300 \\
$\mathrm{~S}$ & -0.58876700 & -2.47417800 & -1.06143200 \\
$\mathrm{O}$ & 0.53647400 & -1.48483800 & -1.18236100 \\
$\mathrm{O}$ & -1.86016000 & -1.91815300 & -1.54507500 \\
$\mathrm{C}$ & -0.14784400 & -3.83650800 & -2.10982300 \\
$\mathrm{H}$ & -0.04500100 & -3.46546400 & -3.13108800 \\
$\mathrm{H}$ & 0.79745000 & -4.25463200 & -1.75868700 \\
$\mathrm{H}$ & -0.93978800 & -4.58546400 & -2.05356900 \\
$\mathrm{C}$ & 0.21340900 & -0.47667700 & 2.12920400 \\
$\mathrm{H}$ & 0.26011000 & -1.51010200 & 1.77471900 \\
$\mathrm{H}$ & 1.21913000 & -0.07651800 & 1.98345700 \\
$\mathrm{C}$ & -0.11905900 & -0.46052000 & 3.62616600 \\
$\mathrm{H}$ & -0.11773900 & 0.56210700 & 4.01857600 \\
$\mathrm{H}$ & -1.11029600 & -0.88883000 & 3.80864600 \\
$\mathrm{H}$ & 0.61275300 & -1.04367900 & 4.19443300 \\
$\mathrm{H}$ & 1.73865500 & -1.63288600 & -0.35858900 \\
$\mathrm{O}$ & 2.62114400 & -1.75100900 & 0.19081400 \\
$\mathrm{~S}$ & 3.49677300 & -0.44586100 & 0.19103100 \\
$\mathrm{O}$ & 2.90575100 & 0.53336200 & -0.72143100 \\
$\mathrm{O}$ & 3.73547700 & -0.02654700 & 1.56536000 \\
$\mathrm{C}$ & 5.02030700 & -1.03390200 & -0.49277000 \\
$\mathrm{H}$ & 5.72290000 & -0.19812700 & -0.50307500 \\
$\mathrm{H}$ & 5.39697800 & -1.83959800 & 0.13972300 \\
$\mathrm{H}$ & 4.83329900 & -1.39100200 & -1.50655600 \\
& & & \\
\hline
\end{tabular}

\section{TS-A}

$\mathrm{E}(\mathrm{SMD} / \mathrm{M06}-2 \mathrm{X} / 6-31 \mathrm{~g}(\mathrm{~d}))=-1428.980377 \mathrm{au}$

$\mathrm{G}(\mathrm{SMD} / \mathrm{M} 06-2 \mathrm{X} / 6-31 \mathrm{~g}(\mathrm{~d}))=-1428.638006$ au $\left(0^{\circ} \mathrm{C}, 1 \mathrm{~atm}\right)$

E (SMD/M06-2X -D3/def2-TZVP//SMD/M06-2X/6-31g(d)) = -1429.593361 au

$\begin{array}{lllr}\text { C } & -3.29364400 & -0.95601700 & -0.51004100 \\ \text { O } & -3.27671000 & -0.33263900 & -1.56113900 \\ \text { O } & -2.40506200 & -1.70616900 & 0.00967300 \\ \text { C } & -4.55278800 & -0.86581600 & 0.37969100 \\ \text { F } & -5.49652400 & -0.08266900 & -0.14932600 \\ \text { F } & -5.09573200 & -2.07970100 & 0.57018600\end{array}$




$\begin{array}{lrrr}\mathrm{F} & -4.25270100 & -0.37417100 & 1.59305400 \\ \mathrm{H} & -1.32742900 & -1.80133200 & -0.81164500 \\ \mathrm{C} & 1.78517500 & -0.02595800 & 2.13763300 \\ \mathrm{C} & 2.17686300 & 1.19006400 & 1.69915700 \\ \mathrm{C} & 2.61165100 & 1.01996100 & 0.32167800 \\ \mathrm{C} & 2.62695300 & -0.39103600 & 0.08282800 \\ \mathrm{~N} & 2.04863600 & -0.96963200 & 1.13578400 \\ \mathrm{H} & 1.34261800 & -0.34990600 & 3.06856400 \\ \mathrm{H} & 2.10628200 & 2.12539800 & 2.23714100 \\ \mathrm{H} & 3.26244100 & 1.70954500 & -0.20210200 \\ \mathrm{C} & 3.97702500 & -2.94789700 & 0.18555600 \\ \mathrm{C} & 2.98886200 & -3.25499900 & 1.32308900 \\ \mathrm{C} & 1.72710600 & -2.39512200 & 1.27612300 \\ \mathrm{H} & 4.61390800 & -3.82309000 & 0.02736900 \\ \mathrm{H} & 3.48046800 & -3.13367000 & 2.29356000 \\ \mathrm{H} & 1.07617800 & -2.67850200 & 0.44469800 \\ \mathrm{H} & 4.64526900 & -2.12929800 & 0.47793600 \\ \mathrm{H} & 2.65584300 & -4.29635700 & 1.25500300 \\ \mathrm{H} & 1.14788500 & -2.49864100 & 2.19445600 \\ \mathrm{C} & 3.26218800 & -2.57956700 & -1.11761200 \\ \mathrm{H} & 2.37725100 & -3.21472300 & -1.24009400 \\ \mathrm{H} & 3.90532900 & -2.78884200 & -1.97727100 \\ \mathrm{C} & 2.85443700 & -1.08662100 & -1.21963900 \\ \mathrm{H} & 3.67125900 & -0.54539000 & -1.70543200 \\ \mathrm{C} & 1.59392400 & -0.92577800 & -2.17176900 \\ \mathrm{H} & 1.73234500 & -0.03340600 & -2.78460800 \\ \mathrm{H} & 1.56405800 & -1.79056600 & -2.83779700 \\ \mathrm{C} & 0.29686900 & -0.83211400 & -1.42443700 \\ \mathrm{O} & -0.43453600 & -1.90625700 & -1.43092800 \\ \mathrm{C} & 0.00452800 & 0.31380600 & -0.69989900 \\ \mathrm{H} & -0.86111900 & 0.35555800 & -0.04888700 \\ \mathrm{C} & 0.92989600 & 1.38779600 & -0.70561800 \\ \mathrm{C} & 0.48882900 & 2.65672900 & -0.02311900 \\ \mathrm{O} & -0.49203100 & 2.75092900 & 0.67511100 \\ \mathrm{O} & 1.33319400 & 3.65742300 & -0.28538700 \\ \mathrm{C} & 1.02459900 & 4.93172200 & 0.31723100 \\ \mathrm{H} & 0.71062200 & 4.76402000 & 1.35028200 \\ \mathrm{H} & 1.97327000 & 5.47024600 & 0.31166500 \\ \mathrm{C} & -0.03675500 & 5.66461300 & -0.47732500 \\ \mathrm{H} & & & \end{array}$

TS-B

$\mathrm{E}(\mathrm{SMD} / \mathrm{M06}-2 \mathrm{X} / 6-31 \mathrm{G}(\mathrm{D}))=-1428.965213$ au

$\mathrm{G}(\mathrm{SMD} / \mathrm{M06}-2 \mathrm{X} / 6-31 \mathrm{G}(\mathrm{D}))=-1428.622568 \mathrm{au}\left(0^{\circ} \mathrm{C}, 1 \mathrm{~atm}\right)$

E (SMD/M06-2X-D3/def2-TZVP// SMD/M06-2X/6-31G(D)) = -1429.577478 au
C
$3.01514700-1.46743600$
0.15495600
O
$2.03534200-1.72785700$
0.84589300
O
$3.21601400-1.66116400$
$-1.08540100$
C
$4.20972500-0.75551000$
0.82530900
$\mathrm{F}$
$4.06642200-0.65606100$
2.14997000 


\begin{tabular}{lrrr}
$\mathrm{F}$ & 5.36282700 & -1.40092100 & 0.59094300 \\
$\mathrm{~F}$ & 4.34612700 & 0.48857000 & 0.33839600 \\
$\mathrm{H}$ & 2.03528000 & -2.13308900 & -1.65910700 \\
$\mathrm{C}$ & -2.67162600 & 1.38496800 & 1.55263100 \\
$\mathrm{C}$ & -1.35453400 & 1.15860700 & 1.80203700 \\
$\mathrm{C}$ & -0.95189900 & 0.04277800 & 0.98307700 \\
$\mathrm{C}$ & -2.13124700 & -0.42593700 & 0.33578800 \\
$\mathrm{~N}$ & -3.12517700 & 0.42584700 & 0.65589300 \\
$\mathrm{H}$ & -3.35253800 & 2.14139100 & 1.91670200 \\
$\mathrm{H}$ & -0.71189100 & 1.73057800 & 2.45653700 \\
$\mathrm{H}$ & -0.03648200 & -0.52459300 & 1.10190700 \\
$\mathrm{C}$ & -4.47228300 & 0.35626500 & 0.09057000 \\
$\mathrm{H}$ & -4.37230800 & 0.30237800 & -0.99756300 \\
$\mathrm{H}$ & -4.97518800 & 1.29493500 & 0.32846500 \\
$\mathrm{C}$ & -2.37342100 & -1.46762900 & -0.72162100 \\
$\mathrm{C}$ & -1.13390700 & -2.25346400 & -1.16181100 \\
$\mathrm{H}$ & -0.82409000 & -2.91642000 & -0.34238100 \\
$\mathrm{H}$ & -1.43237100 & -2.92334800 & -1.97766100 \\
$\mathrm{C}$ & 0.15818300 & -1.59257100 & -1.57093500 \\
$\mathrm{O}$ & 1.04931000 & -2.47610900 & -1.92268800 \\
$\mathrm{C}$ & 0.48988800 & -0.25875900 & -1.43006600 \\
$\mathrm{H}$ & 1.54585000 & -0.00831200 & -1.46581900 \\
$\mathrm{C}$ & -0.37918500 & 0.73835200 & -0.94767100 \\
$\mathrm{H}$ & -1.37591200 & 0.88819900 & -1.34688400 \\
$\mathrm{C}$ & 0.28115800 & 2.02031100 & -0.51036700 \\
$\mathrm{O}$ & 1.41766800 & 2.08571500 & -0.10536900 \\
$\mathrm{O}$ & -0.55552900 & 3.04992100 & -0.62293500 \\
$\mathrm{C}$ & -0.05799100 & 4.32840000 & -0.17570000 \\
$\mathrm{H}$ & -0.95700000 & 4.91240100 & 0.02633000 \\
$\mathrm{H}$ & 0.49393400 & 4.18100500 & 0.75580500 \\
$\mathrm{C}$ & 0.80279100 & 4.97869000 & -1.23923800 \\
$\mathrm{H}$ & 1.11171500 & 5.97229600 & -0.90150400 \\
$\mathrm{H}$ & 1.69931800 & 4.38391500 & -1.43048400 \\
$\mathrm{H}$ & 0.24190000 & 5.08865100 & -2.17165700 \\
$\mathrm{H}$ & -2.75071700 & -0.91447300 & -1.59376300 \\
$\mathrm{H}$ & -4.38342000 & -2.08670000 & 0.86018800 \\
$\mathrm{C}$ & -3.47615600 & -2.49261000 & -0.30553400 \\
$\mathrm{H}$ & -5.03830500 & -2.93229900 & 1.09388800 \\
$\mathrm{H}$ & -2.97684600 & -3.42472500 & -0.02007300 \\
$\mathrm{H}$ & -3.76430500 & -1.92637700 & 1.75075000 \\
\hline & -5.25422300 & -0.84950700 & -1.62675100 \\
$\mathrm{H}$ & & -1.07351000 & -0.09310900 \\
& & -0.57863100 & 1.57037100
\end{tabular}

TS-C

$\mathrm{E}(\mathrm{SMD} / \mathrm{M06}-2 \mathrm{X} / 6-31 \mathrm{G}(\mathrm{D}))=-1428.977808$ au

$\mathrm{G}(\mathrm{SMD} / \mathrm{M06}-2 \mathrm{X} / 6-31 \mathrm{G}(\mathrm{D}))=-1428.636328$ au $\left(0^{\circ} \mathrm{C}, 1 \mathrm{~atm}\right)$

$\mathrm{E}(\mathrm{SMD} / \mathrm{M06}-2 \mathrm{X}-\mathrm{D} 3 / \mathrm{def} 2-\mathrm{TZVP} / /$ SMD/M06-2X/6-31G(D)) = -1429.588559 au
C
$1.70898500-2.10442300-0.16599800$
O
$1.37396600-2.10112200 \quad 1.01155300$
O
$1.00374100-2.24913200-1.21496600$
C
$3.20649800-1.91398000-0.50103300$ 


\begin{tabular}{|c|c|c|c|}
\hline$F$ & 3.93516400 & -1.64526800 & 0.58704100 \\
\hline $\mathrm{F}$ & 3.39005800 & -0.90033100 & -1.36553500 \\
\hline$F$ & 3.71452000 & -3.01549700 & -1.07045500 \\
\hline $\mathrm{H}$ & -0.27288400 & -2.43739700 & -0.84625000 \\
\hline C & -0.21616500 & 0.40024900 & 2.11281100 \\
\hline C & -1.49778300 & 0.83551500 & 2.19587100 \\
\hline C & -1.67799500 & 1.83512500 & 1.16217200 \\
\hline C & -0.38129700 & 2.04338600 & 0.60512700 \\
\hline N & 0.44919200 & 1.15637100 & 1.13965300 \\
\hline $\mathrm{H}$ & 0.32128500 & -0.37600700 & 2.63781100 \\
\hline $\mathrm{H}$ & -2.26145800 & 0.45798400 & 2.86022200 \\
\hline C & 1.82757900 & 0.98728800 & 0.67447500 \\
\hline $\mathrm{H}$ & 2.26454200 & 0.18304800 & 1.26527100 \\
\hline C & -0.00106900 & 2.80744100 & -0.61679300 \\
\hline $\mathrm{H}$ & 0.51729700 & 2.09151400 & -1.27207900 \\
\hline C & -1.28607100 & 3.23789600 & -1.32025300 \\
\hline | & -1.09042300 & 3.67137900 & -2.30372100 \\
\hline $\mathrm{H}$ & -1.79863300 & 4.00280700 & -0.71894300 \\
\hline C & -2.25543000 & 2.07814500 & -1.48225700 \\
\hline $\mathrm{O}$ & -3.05829300 & 2.03163400 & -2.38648200 \\
\hline C & -2.25000500 & 0.94426400 & -0.45566100 \\
\hline $\mathrm{H}$ & -3.25905700 & 0.75374700 & -0.09488100 \\
\hline C & -1.51765400 & -0.23221900 & -0.78196500 \\
\hline $\mathrm{H}$ & -0.63085000 & -0.20013900 & -1.40561300 \\
\hline$\checkmark$ & -1.89746300 & -1.46163000 & -0.26077400 \\
\hline $\mathrm{O}$ & -1.29536700 & -2.58273200 & -0.47650300 \\
\hline 0 & -2.98650000 & -1.50288000 & 0.50666000 \\
\hline C & -3.37464400 & -2.76434300 & 1.08200600 \\
\hline $\mathrm{H}$ & -3.99981500 & -2.48508900 & 1.93214200 \\
\hline $\mathrm{H}$ & -2.48509800 & -3.28049500 & 1.44794200 \\
\hline C & -4.14615900 & -3.60885300 & 0.08831400 \\
\hline & -4.49514700 & -4.52290600 & 0.57841900 \\
\hline $\mathrm{H}$ & -3.51369500 & -3.88814500 & -0.75772600 \\
\hline & -5.01733700 & -3.06171000 & -0.28340200 \\
\hline & 1.77232600 & 0.64343100 & -0.36322800 \\
\hline $\mathrm{H}$ & -2.43945400 & 2.60715100 & 1.18832100 \\
\hline C & 1.91993700 & 3.60809300 & 0.87277400 \\
\hline C & 2.67815700 & 2.27573400 & 0.77909600 \\
\hline & 2.66230600 & 4.40647400 & 0.97197400 \\
\hline $\mathrm{H}$ & 3.31243000 & 2.19968200 & 1.66714800 \\
\hline $\mathrm{H}$ & 1.33872800 & 3.61676800 & 1.80258700 \\
\hline & 3.34904400 & 2.29029700 & -0.08680300 \\
\hline C & 0.98513900 & 3.94794700 & -0.29506800 \\
\hline $\mathrm{H}$ & 1.55996400 & 4.17447000 & -1.19909700 \\
\hline & 0.41616600 & 4.84845400 & -0.03628200 \\
\hline
\end{tabular}

TS-D

E (SMD/M06-2X/6-31G(D)) = -1428.967638 au

$\mathrm{G}(\mathrm{SMD} / \mathrm{M06}-2 \mathrm{X} / 6-31 \mathrm{G}(\mathrm{D}))=-1428.628048$ au $\left(0^{\circ} \mathrm{C}, 1 \mathrm{~atm}\right)$

E (SMD/M06-2X-D3/def2-TZVP// SMD/M06-2X/6-31G(D)) = -1429.578929 au

$\begin{array}{llrr}\mathrm{C} & 4.87579000 & -1.85781400 & -0.85367300 \\ \mathrm{C} & 4.49077100 & -1.84579400 & 0.63091000 \\ \mathrm{H} & 5.69283000 & -2.57267900 & -0.99472300\end{array}$

S-32 


\begin{tabular}{|c|c|c|c|}
\hline $\mathrm{H}$ & 4.20704300 & -2.86608100 & 0.91253400 \\
\hline $\mathrm{H}$ & 4.02864700 & -2.24882900 & -1.42970100 \\
\hline $\mathrm{H}$ & 5.35233300 & -1.57185800 & 1.24851800 \\
\hline C & 5.31265700 & -0.51915400 & -1.46444300 \\
\hline $\mathrm{H}$ & 6.28194800 & -0.21750000 & -1.05346200 \\
\hline $\mathrm{H}$ & 5.45427700 & -0.67170600 & -2.53892700 \\
\hline & -3.41285500 & -0.60329000 & -0.50965400 \\
\hline $\mathrm{O}$ & -2.51735600 & -0.43596000 & -1.31042500 \\
\hline $\mathrm{O}$ & -3.81323700 & 0.16867500 & 0.44660800 \\
\hline C & -4.25494900 & -1.89140200 & -0.55247000 \\
\hline & -3.86173600 & -2.69956200 & -1.53552200 \\
\hline$F$ & -4.15297300 & -2.56307800 & 0.60199700 \\
\hline$F$ & -5.54965200 & -1.60710600 & -0.74125100 \\
\hline $\mathrm{H}$ & -3.19822000 & 1.09156100 & 0.49542900 \\
\hline C & 1.89463100 & 0.64290900 & -2.01328400 \\
\hline C & 0.73569100 & 0.14799000 & -1.52131300 \\
\hline C & 1.05330800 & -0.60224800 & -0.30781100 \\
\hline C & 2.48012500 & -0.54367400 & -0.20801300 \\
\hline $\mathrm{N}$ & 2.94722600 & 0.23038500 & -1.18356200 \\
\hline $\mathrm{H}$ & 2.10636800 & 1.26746500 & -2.86977300 \\
\hline $\mathrm{H}$ & -0.25982800 & 0.28693200 & -1.91999100 \\
\hline$\Pi$ & 0.50397800 & -1.50138700 & -0.04281600 \\
\hline C & 4.34511600 & 0.65852700 & -1.24834500 \\
\hline $\mathrm{H}$ & 4.56847900 & 1.17643600 & -0.31014800 \\
\hline $\mathrm{H}$ & 4.42724000 & 1.38738100 & -2.05562700 \\
\hline C & 3.31132800 & -0.89965700 & 0.97520500 \\
\hline C & 2.37765900 & -1.44402300 & 2.05467900 \\
\hline $\mathrm{H}$ & 2.00771100 & -2.43315600 & 1.74793700 \\
\hline $\mathrm{H}$ & 2.90142700 & -1.58126200 & 3.00419000 \\
\hline C & 1.14148200 & -0.58924000 & 2.31500800 \\
\hline $\mathrm{O}$ & 0.52473800 & -0.71125000 & 3.34975900 \\
\hline C & 0.65511400 & 0.38268300 & 1.23790500 \\
\hline $\mathrm{H}$ & 1.34543400 & 1.21734500 & 1.09080200 \\
\hline C & -0.71987600 & 0.73969400 & 1.28813000 \\
\hline $\mathrm{H}$ & -1.44023500 & 0.04377400 & 1.70189700 \\
\hline C & -1.21269400 & 1.86722900 & 0.63488400 \\
\hline $\mathrm{O}$ & -2.43983400 & 2.17059000 & 0.50155300 \\
\hline $\mathrm{O}$ & -0.28817200 & 2.69660600 & 0.10541500 \\
\hline$c$ & -0.75947000 & 3.84402700 & -0.60988500 \\
\hline $\mathrm{H}$ & 0.07471300 & 4.12155800 & -1.25897500 \\
\hline П & -1.61240800 & 3.55925300 & -1.22987000 \\
\hline C & -1.11830900 & 4.97635000 & 0.33293300 \\
\hline $\mathrm{H}$ & -1.40484700 & 5.86328900 & -0.24085900 \\
\hline $\mathrm{H}$ & -1.95652100 & 4.68870000 & 0.97224600 \\
\hline $\mathrm{H}$ & -0.26280000 & 5.23458900 & 0.96429700 \\
\hline & 3.72887200 & 0.05322100 & 1.33708000 \\
\hline
\end{tabular}

\section{TS-A'}

$E(S M D / M 06-2 X / 6-31 G(D))=-1312.300655$ au

$\mathrm{G}(\mathrm{SMD} / \mathrm{M06}-2 \mathrm{X} / 6-31 \mathrm{G}(\mathrm{D}))=-1312.022079$ au $\left(0^{\circ} \mathrm{C}, 1 \mathrm{~atm}\right)$

E (SMD/M06-2X-D3/def2-TZVP// SMD/M06-2X/6-31G(D)) = -1312.869964 au
C
$-2.86197000-0.25431300$
0.21684300
O
$\begin{array}{lll}-2.75426000 & 0.55630400 & -0.69773200\end{array}$ 


$\begin{array}{lrrr}\mathrm{O} & -2.61781300 & -0.12830200 & 1.45544100 \\ \mathrm{C} & -3.30277200 & -1.68924400 & -0.13977700 \\ \mathrm{~F} & -3.74800800 & -1.79194100 & -1.39476200 \\ \mathrm{~F} & -2.25979100 & -2.52830200 & -0.01052300 \\ \mathrm{~F} & -4.27202400 & -2.13238400 & 0.67266500 \\ \mathrm{H} & -1.85384600 & 0.99560100 & 1.72541100 \\ \mathrm{C} & 0.04326000 & 1.12146100 & -2.08367400 \\ \mathrm{C} & 1.23562500 & 0.48108200 & -2.12522900 \\ \mathrm{C} & 2.10708900 & 1.16286400 & -1.19034100 \\ \mathrm{C} & 1.40052100 & 2.31934100 & -0.75375400 \\ \mathrm{~N} & 0.15958500 & 2.23156300 & -1.23858000 \\ \mathrm{H} & -0.90601400 & 0.91564600 & -2.55678400 \\ \mathrm{H} & 1.46937900 & -0.41236400 & -2.68679000 \\ \mathrm{H} & 3.18649200 & 1.07814100 & -1.15882300 \\ \mathrm{C} & -0.95969900 & 3.13544300 & -0.98869300 \\ \mathrm{H} & -1.82086700 & 2.53825800 & -0.68412900 \\ \mathrm{H} & -1.18470800 & 3.68206600 & -1.90792100 \\ \mathrm{C} & 1.72209500 & 3.18931200 & 0.40450300 \\ \mathrm{H} & 2.80229400 & 3.18434000 & 0.55891300 \\ \mathrm{C} & 1.00049700 & 2.70150200 & 1.72907900 \\ \mathrm{H} & 1.77740100 & 2.38716600 & 2.43251800 \\ \mathrm{H} & 0.46159300 & 3.53636900 & 2.17873800 \\ \mathrm{C} & 0.02882900 & 1.56072200 & 1.57042200 \\ \mathrm{O} & -1.19027300 & 1.82051000 & 1.93034600 \\ \mathrm{C} & 0.43503100 & 0.34054800 & 1.03968900 \\ \mathrm{H} & -0.27799100 & -0.45714500 & 0.86705100 \\ \mathrm{C} & 1.75960900 & 0.18669700 & 0.59537400 \\ \mathrm{C} & 2.16832900 & -1.18967800 & 0.14751500 \\ \mathrm{O} & 1.39223500 & -2.08282200 & -0.09669000 \\ \mathrm{O} & 3.49565300 & -1.28626400 & 0.04651100 \\ \mathrm{C} & 4.01574500 & -2.56528700 & -0.37369000 \\ \mathrm{H} & 3.39383900 & -2.94615300 & -1.18704800 \\ \mathrm{H} & 5.01201700 & -2.33971800 & -0.75632100 \\ \mathrm{C} & 4.07164800 & -3.53472000 & 0.78909700 \\ \mathrm{H} & 4.53052500 & -4.47209000 & 0.46124000 \\ \mathrm{H} & 4.67276400 & -3.12139600 & 1.60392500 \\ \mathrm{H} & 3.06784600 & -3.75313200 & 1.16200200 \\ \mathrm{H} & 2.55956500 & 0.74247200 & 1.07714500 \\ \mathrm{H} & -0.70059500 & 3.84304100 & -0.20232100 \\ \mathrm{H} & 1.42424500 & 4.22181700 & 0.20964500\end{array}$

TS-B'

$E(S M D / M 06-2 X / 6-31 G(D))=-1312.279702$ au

$\mathrm{G}(\mathrm{SMD} / \mathrm{M06}-2 \mathrm{X} / 6-31 \mathrm{G}(\mathrm{D}))=-1312.002657 \mathrm{au}\left(0^{\circ} \mathrm{C}, 1 \mathrm{~atm}\right)$

E (SMD/M06-2X-D3/def2-TZVP// SMD/M06-2X/6-31G(D)) $=-1312.851416$ au

$\begin{array}{lrrr}\text { C } & 2.91674500 & -0.73888100 & 0.15827200 \\ \text { O } & 2.08201700 & -1.20542500 & 0.92626100 \\ \text { O } & 3.11981900 & -0.97963900 & -1.07363800 \\ \text { C } & 3.88399100 & 0.33588400 & 0.69875700 \\ \text { F } & 3.72556400 & 0.55344000 & 2.00710200 \\ \text { F } & 5.16436600 & -0.01439100 & 0.49918100 \\ \text { F } & 3.68991800 & 1.50512600 & 0.06743800 \\ \text { H } & 2.13874300 & -1.84954900 & -1.53102300\end{array}$

S-34 


$\begin{array}{lrrr}\text { C } & -3.32403600 & 0.09618500 & 1.81718300 \\ \mathrm{C} & -1.99656400 & 0.35678400 & 1.94249200 \\ \mathrm{C} & -1.29708100 & -0.58855000 & 1.11070000 \\ \mathrm{C} & -2.28821900 & -1.46308100 & 0.57637200 \\ \mathrm{~N} & -3.48622200 & -1.00671000 & 0.98524900 \\ \mathrm{H} & -4.19484700 & 0.57874700 & 2.23807100 \\ \mathrm{H} & -1.54318600 & 1.13938200 & 2.53437100 \\ \mathrm{H} & -0.23855500 & -0.80870900 & 1.17499200 \\ \mathrm{C} & -4.77631200 & -1.51938500 & 0.54517300 \\ \mathrm{H} & -4.95121400 & -1.26348700 & -0.50351800 \\ \mathrm{H} & -5.55317700 & -1.06759800 & 1.16137200 \\ \mathrm{C} & -2.21671000 & -2.54778500 & -0.45436000 \\ \mathrm{H} & -2.70410800 & -3.44329000 & -0.05018000 \\ \mathrm{C} & -0.82850300 & -2.96892600 & -0.93504400 \\ \mathrm{H} & -0.30993600 & -3.50176000 & -0.12850900 \\ \mathrm{H} & -0.95074800 & -3.70328000 & -1.73938800 \\ \mathrm{C} & 0.18638400 & -1.95468700 & -1.40045300 \\ \mathrm{O} & 1.31465900 & -2.52063500 & -1.71858500 \\ \mathrm{C} & 0.06235500 & -0.57781200 & -1.35675800 \\ \mathrm{H} & 0.97593200 & 0.00155700 & -1.44848700 \\ \mathrm{C} & -1.07496700 & 0.11064600 & -0.89544900 \\ \mathrm{H} & -2.07696100 & -0.11461400 & -1.24034700 \\ \mathrm{C} & -0.87687200 & 1.56749800 & -0.57057900 \\ \mathrm{O} & 0.18902400 & 2.05176800 & -0.27129900 \\ \mathrm{O} & -2.02905500 & 2.23069300 & -0.64514800 \\ \mathrm{C} & -1.98695000 & 3.62782000 & -0.28784400 \\ \mathrm{H} & -3.01713900 & 3.86988900 & -0.02279300 \\ \mathrm{H} & -1.35053300 & 3.74332400 & 0.59283100 \\ \mathrm{C} & -1.49629700 & 4.47005100 & -1.44757700 \\ \mathrm{H} & -1.53783400 & 5.52830600 & -1.17354700 \\ \mathrm{H} & -0.46347900 & 4.21829900 & -1.70072600 \\ \mathrm{H} & -2.12729700 & 4.31518100 & -2.32734300 \\ \mathrm{H} & -4.80767200 & -2.60378400 & 0.66586000 \\ \mathrm{H} & -2.83656000 & -2.23788500 & -1.30791300 \\ & & & \end{array}$

TS-C'

E (SMD/M06-2X/6-31G(D)) = -1312.292965 au

$\mathrm{G}(\mathrm{SMD} / \mathrm{M06}-2 \mathrm{X} / 6-31 \mathrm{G}(\mathrm{D}))=-1312.015209$ au $\left(0^{\circ} \mathrm{C}, 1 \mathrm{~atm}\right)$

E (SMD/M06-2X-D3/def2-TZVP// SMD/M06-2X/6-31G(D)) = -1312.862759 au

$\begin{array}{lrrr}\mathrm{C} & -2.43864600 & -0.88666400 & 0.09778600 \\ \mathrm{O} & -2.11818200 & -1.04486100 & -1.07359800 \\ \mathrm{O} & -1.87100900 & -1.28869500 & 1.16230400 \\ \mathrm{C} & -3.72904600 & -0.09172800 & 0.40255100 \\ \mathrm{~F} & -4.23801600 & 0.48455600 & -0.69143700 \\ \mathrm{~F} & -3.50100700 & 0.88302200 & 1.29941100 \\ \mathrm{~F} & -4.67371300 & -0.89056000 & 0.91877800 \\ \mathrm{H} & -0.73250600 & -1.92627900 & 0.84402200 \\ \mathrm{C} & 0.38743100 & 0.51625600 & -2.21405800 \\ \mathrm{C} & 1.73999700 & 0.45701000 & -2.21812800 \\ \mathrm{C} & 2.20617300 & 1.44242100 & -1.26500900 \\ \mathrm{C} & 1.04737100 & 2.18490700 & -0.87652500 \\ \mathrm{~N} & -0.01533300 & 1.57890800 & -1.39088500 \\ \mathrm{H} & -0.36771800 & -0.08127000 & -2.70361900\end{array}$

S-35 


$\begin{array}{lrrr}\mathrm{H} & 2.35094100 & -0.25374200 & -2.75501100 \\ \mathrm{C} & -1.40097400 & 1.95793300 & -1.13583300 \\ \mathrm{H} & -1.54802400 & 3.00351100 & -1.41447300 \\ \mathrm{H} & -2.04845600 & 1.31648500 & -1.72958300 \\ \mathrm{C} & 0.98589000 & 3.22955700 & 0.18447200 \\ \mathrm{H} & 0.10040400 & 3.06414900 & 0.80871800 \\ \mathrm{C} & 2.25876300 & 3.13785800 & 1.03104700 \\ \mathrm{H} & 2.19014000 & 3.74508800 & 1.93500500 \\ \mathrm{H} & 3.11533600 & 3.50583600 & 0.45054500 \\ \mathrm{C} & 2.58349100 & 1.71089400 & 1.42928900 \\ \mathrm{O} & 3.10232800 & 1.44164900 & 2.48928900 \\ \mathrm{C} & 2.28633100 & 0.57413100 & 0.45339700 \\ \mathrm{H} & 3.19855800 & 0.02666500 & 0.22095200 \\ \mathrm{C} & 1.17035300 & -0.25869600 & 0.75459900 \\ \mathrm{H} & 0.30293900 & 0.11647800 & 1.28570400 \\ \mathrm{C} & 1.15163700 & -1.58012500 & 0.33176900 \\ \mathrm{O} & 0.19461500 & -2.42238300 & 0.53751300 \\ \mathrm{O} & 2.21736200 & -2.03568300 & -0.32763700 \\ \mathrm{C} & 2.21643900 & -3.40355200 & -0.77628600 \\ \mathrm{H} & 2.96181200 & -3.41998500 & -1.57362000 \\ \mathrm{H} & 1.23848300 & -3.64297000 & -1.19810800 \\ \mathrm{C} & 2.59226800 & -4.35045200 & 0.34544800 \\ \mathrm{H} & 2.66078300 & -5.37083800 & -0.04381300 \\ \mathrm{H} & 1.84056900 & -4.33088000 & 1.13820100 \\ \mathrm{H} & 3.56293700 & -4.07583900 & 0.76840300 \\ \mathrm{H} & -1.63536800 & 1.83066000 & -0.07570200 \\ \mathrm{H} & 0.88704600 & 4.22859800 & -0.25472500 \\ \mathrm{H} & 3.19829300 & 1.88011300 & -1.27754400\end{array}$

\section{TS-D'}

$E(S M D / M 06-2 X / 6-31 G(D))=-1312.282304$ au

$\mathrm{G}(\mathrm{SMD} / \mathrm{M06}-2 \mathrm{X} / 6-31 \mathrm{G}(\mathrm{D}))=-1312.009617$ au $\left(0^{\circ} \mathrm{C}, 1 \mathrm{~atm}\right)$

E (SMD/M06-2X-D3/def2-TZVP// SMD/M06-2X/6-31G(D)) =-1312.852700 au

$\begin{array}{lrrr}\mathrm{C} & -2.94067600 & -0.03388100 & -0.41930600 \\ \mathrm{O} & -2.09779700 & 0.04108200 & -1.28806000 \\ \mathrm{O} & -3.09530900 & 0.69543900 & 0.63693400 \\ \mathrm{C} & -4.01769100 & -1.13203900 & -0.48373700 \\ \mathrm{~F} & -3.91579000 & -1.84934800 & -1.60144600 \\ \mathrm{~F} & -3.89626600 & -1.96736100 & 0.55716000 \\ \mathrm{~F} & -5.24715100 & -0.60563300 & -0.43764300 \\ \mathrm{H} & -2.28573500 & 1.44986900 & 0.71200600 \\ \mathrm{C} & 2.39014500 & 0.08994400 & -2.22193000 \\ \mathrm{C} & 1.18046100 & -0.19089500 & -1.68978900 \\ \mathrm{C} & 1.39345600 & -1.12143300 & -0.58644900 \\ \mathrm{C} & 2.80005600 & -1.39845600 & -0.59930800 \\ \mathrm{~N} & 3.37015800 & -0.63810400 & -1.52963600 \\ \mathrm{H} & 2.69035000 & 0.74693600 & -3.02606300 \\ \mathrm{H} & 0.22116300 & 0.20950900 & -1.98773500 \\ \mathrm{H} & 0.66908900 & -1.89620900 & -0.35341800 \\ \mathrm{C} & 4.80354900 & -0.46239700 & -1.72147700 \\ \mathrm{H} & 5.18063600 & 0.32055900 & -1.05795900 \\ \mathrm{H} & 4.98156600 & -0.17845200 & -2.75895600 \\ \mathrm{C} & 3.54170000 & -2.09766500 & 0.48625600\end{array}$




$\begin{array}{lrrr}\mathrm{H} & 4.06430200 & -2.98379800 & 0.10867900 \\ \mathrm{C} & 2.55610400 & -2.48436100 & 1.58834900 \\ \mathrm{H} & 1.91290500 & -3.30162000 & 1.23516900 \\ \mathrm{H} & 3.07471100 & -2.85044200 & 2.47672100 \\ \mathrm{C} & 1.61436100 & -1.36865900 & 2.02143200 \\ \mathrm{O} & 1.06791400 & -1.42060900 & 3.10097800 \\ \mathrm{C} & 1.31926700 & -0.21564000 & 1.06382200 \\ \mathrm{H} & 2.17870100 & 0.44582000 & 0.92855000 \\ \mathrm{C} & 0.07465200 & 0.44442800 & 1.24536100 \\ \mathrm{H} & -0.76617100 & -0.09946600 & 1.65967500 \\ \mathrm{C} & -0.16798300 & 1.72036700 & 0.73927700 \\ \mathrm{O} & -1.28967400 & 2.31732600 & 0.74244300 \\ \mathrm{O} & 0.89537900 & 2.35914200 & 0.20749700 \\ \mathrm{C} & 0.67381700 & 3.65517800 & -0.36010700 \\ \mathrm{H} & 1.50633500 & 3.79449500 & -1.05410000 \\ \mathrm{H} & -0.26135100 & 3.64782800 & -0.92429000 \\ \mathrm{C} & 0.66477700 & 4.73341300 & 0.70619300 \\ \mathrm{H} & 0.56610500 & 5.71862300 & 0.23970800 \\ \mathrm{H} & -0.17457400 & 4.58575700 & 1.39011900 \\ \mathrm{H} & 1.59691800 & 4.71372800 & 1.27884500 \\ \mathrm{H} & 5.31572300 & -1.40213300 & -1.51166100 \\ \mathrm{H} & 4.31103100 & -1.41966100 & 0.87967600\end{array}$

TS-A"

$E(S M D / M 06-2 X / 6-31 G(D))=-1314.474804$ au

$\mathrm{G}(\mathrm{SMD} / \mathrm{M06}-2 \mathrm{X} / 6-31 \mathrm{G}(\mathrm{D}))=-1314.164851 \mathrm{au}\left(0^{\circ} \mathrm{C}, 1 \mathrm{~atm}\right)$

E (SMD/M06-2X-D3/def2-TZVP// SMD/M06-2X/6-31G(D)) = -1315.039631 au

$\begin{array}{lrrr}\mathrm{C} & -3.25086800 & -0.66934700 & -0.48145500 \\ \mathrm{O} & -3.21856200 & -0.07683600 & -1.55075400 \\ \mathrm{O} & -2.36207100 & -1.38050600 & 0.08754900 \\ \mathrm{C} & -4.54234100 & -0.58941900 & 0.36257500 \\ \mathrm{~F} & -5.46991400 & 0.19458000 & -0.19398400 \\ \mathrm{~F} & -5.08743900 & -1.80770100 & 0.52054800 \\ \mathrm{~F} & -4.29193800 & -0.10853200 & 1.59121000 \\ \mathrm{H} & -1.24353600 & -1.47150400 & -0.70845600 \\ \mathrm{C} & 1.89307300 & 0.56551800 & 2.13010100 \\ \mathrm{C} & 2.18294600 & 1.79292900 & 1.64718200 \\ \mathrm{C} & 2.56890100 & 1.61668800 & 0.25618400 \\ \mathrm{C} & 2.67212400 & 0.20301400 & 0.05090900 \\ \mathrm{~N} & 2.17965200 & -0.38489800 & 1.14016000 \\ \mathrm{H} & 1.51282100 & 0.23653900 & 3.08650800 \\ \mathrm{H} & 2.06888100 & 2.73460000 & 2.16563400 \\ \mathrm{H} & 3.16737600 & 2.32431100 & -0.30542300 \\ \mathrm{C} & 4.22500100 & -2.23058100 & 0.18585600 \\ \mathrm{C} & 3.29436400 & -2.58590400 & 1.35716800 \\ \mathrm{C} & 1.96948500 & -1.82550600 & 1.32546600 \\ \mathrm{H} & 4.92860000 & -3.05426400 & 0.03367700 \\ \mathrm{H} & 3.80031900 & -2.40387400 & 2.31067000 \\ \mathrm{H} & 1.32152800 & -2.17836900 & 0.51865900 \\ \mathrm{H} & 4.82989300 & -1.35164400 & 0.43838000 \\ \mathrm{H} & 3.04149000 & -3.65115600 & 1.32100000 \\ \mathrm{H} & 1.42265800 & -1.94759500 & 2.26127500 \\ \mathrm{C} & 3.44922400 & -1.96174800 & -1.10692400\end{array}$




$\begin{array}{lrrr}\mathrm{H} & 2.62183500 & -2.67602900 & -1.18857200 \\ \mathrm{H} & 4.08770700 & -2.13840200 & -1.97726000 \\ \mathrm{C} & 2.90630700 & -0.51390100 & -1.23838200 \\ \mathrm{H} & 3.65437400 & 0.07868300 & -1.77267700 \\ \mathrm{C} & 1.60067000 & -0.49308700 & -2.14140000 \\ \mathrm{H} & 1.65157300 & 0.37512400 & -2.80120700 \\ \mathrm{H} & 1.60647000 & -1.38978400 & -2.76449700 \\ \mathrm{C} & 0.32491400 & -0.44806200 & -1.35344600 \\ \mathrm{O} & -0.34714700 & -1.56228500 & -1.30985600 \\ \mathrm{C} & -0.01156300 & 0.69905400 & -0.65484100 \\ \mathrm{H} & -0.85954600 & 0.70908900 & 0.02046900 \\ \mathrm{C} & 0.83357000 & 1.83804400 & -0.72648600 \\ \mathrm{C} & 0.31330700 & 3.10921800 & -0.07718800 \\ \mathrm{O} & -0.58498300 & 3.06504800 & 0.73430100 \\ \mathrm{H} & 1.36021600 & 2.02616100 & -1.65960300 \\ \mathrm{C} & 0.94266900 & 4.40126500 & -0.52613600 \\ \mathrm{H} & 0.58785900 & 5.22475400 & 0.09477300 \\ \mathrm{H} & 2.03516300 & 4.34472400 & -0.48954700 \\ \mathrm{H} & 0.66176500 & 4.58537100 & -1.56991800\end{array}$

\section{TS-B"}

$\mathrm{E}(\mathrm{SMD} / \mathrm{M06}-2 \mathrm{X} / 6-31 \mathrm{G}(\mathrm{D}))=-1314.460748 \mathrm{au}$

$\mathrm{G}(\mathrm{SMD} / \mathrm{M06}-2 \mathrm{X} / 6-31 \mathrm{G}(\mathrm{D}))=-1314.150944 \mathrm{au}\left(0^{\circ} \mathrm{C}, 1 \mathrm{~atm}\right)$

E (SMD/M06-2X-D3/def2-TZVP// SMD/M06-2X/6-31G(D)) = -1315.024116 au

$\begin{array}{lrrr}\mathrm{C} & 3.05151200 & -0.94397800 & 0.32681500 \\ \mathrm{O} & 2.07861600 & -1.04149200 & 1.06789700 \\ \mathrm{O} & 3.26297000 & -1.45529700 & -0.81770900 \\ \mathrm{C} & 4.22451700 & -0.04867000 & 0.77951400 \\ \mathrm{~F} & 4.05469100 & 0.43127700 & 2.01483500 \\ \mathrm{~F} & 5.38692600 & -0.72101200 & 0.76444900 \\ \mathrm{~F} & 4.36373300 & 0.99990000 & -0.04650600 \\ \mathrm{H} & 2.08838600 & -2.07845100 & -1.25850000 \\ \mathrm{C} & -2.65296400 & 2.01413300 & 1.08963500 \\ \mathrm{C} & -1.32506000 & 1.87282400 & 1.35024300 \\ \mathrm{C} & -0.91188400 & 0.60962100 & 0.79063200 \\ \mathrm{C} & -2.08990500 & -0.00864900 & 0.28439000 \\ \mathrm{~N} & -3.09733600 & 0.87558600 & 0.43058200 \\ \mathrm{H} & -3.34557400 & 2.81703300 & 1.30014000 \\ \mathrm{H} & -0.68549700 & 2.58404300 & 1.85377100 \\ \mathrm{H} & 0.01721000 & 0.10064200 & 1.01832500 \\ \mathrm{C} & -4.45721000 & 0.65291700 & -0.05924200 \\ \mathrm{H} & -4.38699000 & 0.33658100 & -1.10421400 \\ \mathrm{H} & -4.97514600 & 1.61296600 & -0.03877000 \\ \mathrm{C} & -2.32595200 & -1.25675300 & -0.52277500 \\ \mathrm{C} & -1.08289800 & -2.11792300 & -0.76719300 \\ \mathrm{H} & -0.77805700 & -2.57980100 & 0.18159300 \\ \mathrm{H} & -1.37463700 & -2.95473100 & -1.41418400 \\ \mathrm{C} & 0.20592600 & -1.55805700 & -1.31147200 \\ \mathrm{O} & 1.11075100 & -2.48934200 & -1.43332000 \\ \mathrm{C} & 0.52472800 & -0.22674000 & -1.49667900 \\ \mathrm{H} & 1.58011500 & 0.00825300 & -1.59483700 \\ \mathrm{C} & -0.33343100 & 0.86212000 & -1.24961300 \\ \mathrm{H} & -1.34007600 & 0.90829700 & -1.65365100\end{array}$




$\begin{array}{lrrr}\mathrm{C} & 0.35157400 & 2.21495700 & -1.12431400 \\ \mathrm{O} & 1.48854900 & 2.27831700 & -0.71159700 \\ \mathrm{H} & -2.69010500 & -0.90567800 & -1.49955200 \\ \mathrm{C} & -4.29088500 & -1.56080100 & 1.20654100 \\ \mathrm{C} & -3.43456900 & -2.17264000 & 0.09327100 \\ \mathrm{H} & -4.91940500 & -2.35088800 & 1.62970900 \\ \mathrm{H} & -2.94245400 & -3.05775600 & 0.50978500 \\ \mathrm{H} & -3.63287300 & -1.22747800 & 2.01769600 \\ \mathrm{H} & -4.07638700 & -2.52662900 & -0.72133300 \\ \mathrm{C} & -5.19141600 & -0.39935100 & 0.77768000 \\ \mathrm{H} & -6.03033100 & -0.76930200 & 0.17823600 \\ \mathrm{H} & -5.61276600 & 0.07329200 & 1.67078900 \\ \mathrm{C} & -0.43959800 & 3.41108100 & -1.57308800 \\ \mathrm{H} & 0.10564000 & 4.32895100 & -1.34956800 \\ \mathrm{H} & -0.60904300 & 3.33679200 & -2.65425600 \\ \mathrm{H} & -1.42081000 & 3.42123700 & -1.08849100\end{array}$

\section{TS-C"}

$\mathrm{E}(\mathrm{SMD} / \mathrm{M} 06-2 \mathrm{X} / 6-31 \mathrm{G}(\mathrm{D}))=-1314.482721 \mathrm{au}$

$\mathrm{G}(\mathrm{SMD} / \mathrm{M} 06-2 \mathrm{X} / 6-31 \mathrm{G}(\mathrm{D}))=-1314.170928$ au $\left(0^{\circ} \mathrm{C}, 1 \mathrm{~atm}\right)$

E (SMD/M06-2X-D3/def2-TZVP// SMD/M06-2X/6-31G(D)) = -1315.045916 au

$\begin{array}{lrrr}\mathrm{C} & -2.61964800 & -0.88170400 & 0.09439100 \\ \mathrm{O} & -2.43651100 & -1.07899400 & -1.10297900 \\ \mathrm{O} & -2.12308600 & -1.46379700 & 1.10479600 \\ \mathrm{C} & -3.60786600 & 0.24189400 & 0.49346600 \\ \mathrm{~F} & -3.96928900 & 0.99447100 & -0.55224300 \\ \mathrm{~F} & -3.07408500 & 1.06904100 & 1.41061900 \\ \mathrm{~F} & -4.72595300 & -0.26985900 & 1.02983800 \\ \mathrm{H} & -1.25583100 & -2.50377000 & 0.60112300 \\ \mathrm{C} & 0.57095900 & -0.11342100 & -2.20953400 \\ \mathrm{C} & 1.85864600 & -0.53871100 & -2.34040500 \\ \mathrm{C} & 2.60600600 & 0.04024700 & -1.25634200 \\ \mathrm{C} & 1.70793800 & 0.90406700 & -0.57954400 \\ \mathrm{~N} & 0.50419600 & 0.77931000 & -1.14361500 \\ \mathrm{H} & -0.32473700 & -0.34214500 & -2.76966400 \\ \mathrm{H} & 2.23348900 & -1.22256700 & -3.08840900 \\ \mathrm{C} & -0.67926600 & 1.47019300 & -0.63028300 \\ \mathrm{H} & -1.51558600 & 1.17443700 & -1.26232600 \\ \mathrm{C} & 1.86648800 & 1.64551900 & 0.70452900 \\ \mathrm{H} & 0.99415600 & 1.38348300 & 1.32111100 \\ \mathrm{C} & 3.10870200 & 1.10620500 & 1.40713000 \\ \mathrm{H} & 3.22351800 & 1.50870300 & 2.41604400 \\ \mathrm{H} & 4.00798700 & 1.37801000 & 0.83531500 \\ \mathrm{C} & 3.06849200 & -0.40770000 & 1.48704300 \\ \mathrm{O} & 3.57646500 & -1.03103600 & 2.39082500 \\ \mathrm{C} & 2.39408900 & -1.20944300 & 0.37239600 \\ \mathrm{H} & 3.09959500 & -1.91286100 & -0.06138700 \\ \mathrm{C} & 1.06865300 & -1.66571700 & 0.56255700 \\ \mathrm{H} & 0.39416400 & -1.10376000 & 1.20499600 \\ \mathrm{C} & 0.57082400 & -2.80160500 & -0.05790800 \\ \mathrm{O} & -0.64421600 & -3.22497400 & 0.13650700 \\ \mathrm{H} & -0.86796700 & 1.07644800 & 0.37319400 \\ \mathrm{H} & 3.68510100 & 0.11387700 & -1.19897500\end{array}$




$\begin{array}{lrrr}\mathrm{C} & 0.89467000 & 3.57825200 & -0.65368300 \\ \mathrm{C} & -0.53162200 & 3.01114700 & -0.59306700 \\ \mathrm{H} & 0.81871900 & 4.67011100 & -0.67255000 \\ \mathrm{H} & -1.08425400 & 3.43078600 & -1.43879800 \\ \mathrm{H} & 1.34705900 & 3.28791500 & -1.60954800 \\ \mathrm{H} & -1.03330700 & 3.36244300 & 0.31549400 \\ \mathrm{C} & 1.84002300 & 3.16985100 & 0.48381900 \\ \mathrm{H} & 1.54728100 & 3.65103000 & 1.42300900 \\ \mathrm{H} & 2.85213000 & 3.51438200 & 0.24130400 \\ \mathrm{C} & 1.34300300 & -3.69249300 & -0.98216300 \\ \mathrm{H} & 0.81643600 & -3.72970600 & -1.94099100 \\ \mathrm{H} & 1.34466100 & -4.70724600 & -0.57099700 \\ \mathrm{H} & 2.37019300 & -3.37668700 & -1.15417300\end{array}$

TS-D"

E (SMD/M06-2X/6-31G(D)) = -1314.473099 au

$\mathrm{G}(\mathrm{SMD} / \mathrm{M06}-2 \mathrm{X} / 6-31 \mathrm{G}(\mathrm{D}))=-1314.163147 \mathrm{au}\left(0^{\circ} \mathrm{C}, 1 \mathrm{~atm}\right)$

E (SMD/M06-2X-D3/def2-TZVP// SMD/M06-2X/6-31G(D)) = -1315.035576 au

C

C $\quad 3.77325300 \quad-1.82360100 \quad 0.47883600$

$4.43864300-1.40401700-0.83779000$

$\mathrm{H} \quad 5.24053100-2.11456800-1.06299400$

$\mathrm{H} \quad 3.36193000 \quad-2.83043600 \quad 0.34340100$

H $\quad 3.70567600 \quad-1.50786200-1.64664800$

$\mathrm{H} \quad 4.51382800 \quad-1.88493600 \quad 1.28319000$

C $\quad 5.03580200 \quad 0.00910800-0.89373700$

$\mathrm{H} \quad 5.89543700 \quad 0.07928900-0.21861500$

$\mathrm{H} \quad \begin{array}{llll}\mathrm{H} & .41367500 & 0.16799400 & -1.90844800\end{array}$

C $\quad-3.22319200 \quad-0.00630100-0.83009900$

O $\quad-2.52146000 \quad 0.51727700 \quad-1.69139600$

$\begin{array}{llll}O & -3.94243800 & 0.51704600 & 0.07083100\end{array}$

C $\quad-3.15452400-1.54692400-0.72523300$

F $\quad-2.74828400 \quad-2.12608000-1.85927000$

F $\quad-2.25286300 \quad-1.88100700 \quad 0.22995300$

F $\quad-4.31763700 \quad-2.10514200-0.37543700$

$\mathrm{H} \quad-3.34964800 \quad 1.83377600 \quad 0.39047500$

C $\quad 1.81486900 \quad 1.52896200 \quad-1.67706000$

C $\quad 0.57396000 \quad 0.98092100 \quad-1.57546700$

C $\quad 0.65496600 \quad-0.08449800-0.60338400$

C $\quad 2.01210500 \quad-0.14151500-0.20402600$

N $\quad 2.67799300 \quad 0.84315400 \quad-0.82681900$

$\mathrm{H} \quad 2.18940700 \quad 2.35029600-2.27212300$

$\mathrm{H} \quad-0.32307800 \quad 1.27381400 \quad-2.10194500$

$\mathrm{H} \quad-0.04933500 \quad-0.90529700-0.54087800$

$\begin{array}{llll}\text { C } & 4.07476200 & 1.15992600 & -0.53271300\end{array}$

H $\quad 4.13925700 \quad 1.39737700 \quad 0.53396800$

$\mathrm{H} \quad 4.32502300 \quad 2.06616300 \quad-1.08628300$

C $\quad 2.62948900-0.88342600 \quad 0.93140800$

C $\quad 1.51384200-1.58962600 \quad 1.69431400$

$\mathrm{H} \quad 1.10246400 \quad-2.40195800 \quad 1.07781700$

H $\quad 1.88027700 \quad-2.04558600 \quad 2.61785000$

C $\quad 0.34036400 \quad-0.68872700 \quad 2.04240000$

O $\quad-0.46680900-1.01231100 \quad 2.88425000$

C $\quad 0.13648600 \quad 0.62650200 \quad 1.29197300$

S-40 


$\begin{array}{lrrr}\mathrm{H} & 0.95455200 & 1.34202200 & 1.37573000 \\ \mathrm{C} & -1.18516600 & 1.09860400 & 1.21862800 \\ \mathrm{H} & -1.97840800 & 0.37221300 & 1.35106500 \\ \mathrm{C} & -1.53839400 & 2.37883500 & 0.82981900 \\ \mathrm{O} & -2.77834800 & 2.69311800 & 0.56644200 \\ \mathrm{H} & 3.06116400 & -0.11798700 & 1.59469700 \\ \mathrm{C} & -0.59201300 & 3.52372500 & 0.66458800 \\ \mathrm{H} & 0.39462900 & 3.33158300 & 1.08557800 \\ \mathrm{H} & -0.48823600 & 3.74557900 & -0.40336500 \\ \mathrm{H} & -1.02509500 & 4.40778800 & 1.14228600\end{array}$

$(\mathrm{TFA})_{2}$

$E(S M D / M 06-2 X / 6-31 G(D))=-1053.235167$ au

$\mathrm{G}(\mathrm{SMD} / \mathrm{M06}-2 \mathrm{X} / 6-31 \mathrm{G}(\mathrm{D}))=-1053.193681 \mathrm{au}\left(0^{\circ} \mathrm{C}, 1 \mathrm{~atm}\right)$

E (SMD/M06-2X-D3/def2-TZVP// SMD/M06-2X/6-31G(D)) = -1053.730372 au

$\begin{array}{lrrr}\text { C } & -1.88685400 & 0.02358300 & -0.00762500 \\ \text { O } & -1.41828600 & -1.19108700 & -0.00487100 \\ \text { O } & -1.26011400 & 1.06243300 & -0.01242200 \\ \text { C } & -3.42317000 & 0.02378800 & 0.00288400 \\ \text { F } & -3.86668300 & -0.55968800 & 1.11624000 \\ \text { F } & -3.88776800 & 1.26332200 & -0.04993500 \\ \text { F } & -3.88710300 & -0.65985300 & -1.04253000 \\ \text { C } & 1.88750700 & 0.04205900 & -0.01731600 \\ \text { O } & 1.42242300 & 1.25590800 & -0.01193100 \\ \text { O } & 1.25653200 & -0.99583600 & -0.02355400 \\ \text { C } & 3.42305000 & -0.02778500 & 0.00215900 \\ \text { F } & 3.98187000 & 1.16936300 & -0.11883300 \\ F & 3.81734400 & -0.57369000 & 1.15241000 \\ F & 3.84103500 & -0.80425400 & -0.99480000 \\ \text { H } & -0.41903600 & -1.17138800 & -0.00933500 \\ \text { H } & 0.42314900 & 1.23338400 & -0.01200600\end{array}$

22 (V)

$E(S M D / M 06-2 X / 6-31 G(D))=-902.386332454$ au

$\mathrm{G}(\mathrm{SMD} / \mathrm{M06}-2 \mathrm{X} / 6-31 \mathrm{G}(\mathrm{D}))=-902.076804 \mathrm{au}\left(0^{\circ} \mathrm{C}, 1 \mathrm{~atm}\right)$

$\mathrm{E}(\mathrm{SMD} / \mathrm{M06}-2 \mathrm{X}-\mathrm{D} 3 / \mathrm{def} 2-\mathrm{TZVP} / / \mathrm{SMD} / \mathrm{M06}-2 \mathrm{X} / 6-31 \mathrm{G}(\mathrm{D}))=-902.749560323 \mathrm{au}$

C

C

$-4.27409700-1.70956600-0.35672300$

C

$-3.80420200-1.90004100-1.63265300$

C

$-2.64364900-1.09213700-1.76536700$

C

$-2.43928100$

$-0.43333200-0.56589400$

$\begin{array}{lll}-3.45003900 & -0.82435100 & 0.29024300\end{array}$

$\begin{array}{lll}-5.12872900 & -2.12637200 & 0.15823800\end{array}$

$\mathrm{H}$

$-4.23783700-2.54726400$

$-2.38260200$

$\begin{array}{lll}-2.02516600 & -1.00700000 & -2.64798700\end{array}$

$\begin{array}{lll}-1.88474600 & 1.30014900 & 2.19886500\end{array}$

$\begin{array}{lll}-2.46958700 & -0.08983200 & 2.46770600\end{array}$

$\begin{array}{lll}-3.72958200 & -0.37418900 & 1.65685500\end{array}$

$\begin{array}{lll}-2.46720600 & 2.05161600 & 2.74471300\end{array}$

$\begin{array}{lll}-1.73358200 & -0.87239000 & 2.24980100\end{array}$

$\begin{array}{lll}-4.37037300 & 0.51613500 & 1.62608100\end{array}$

$\begin{array}{llll}-0.86439400 & 1.33899800 & 2.59840200\end{array}$

$\begin{array}{lll}-2.71525700 & -0.18022900 & 3.53064100\end{array}$

$\mathrm{H}$

$-4.30511300-1.17643600$

2.12441000

S-41 


$\begin{array}{lrrr}\mathrm{C} & -1.86327400 & 1.67477300 & 0.71425300 \\ \mathrm{H} & -2.86884100 & 1.95321400 & 0.37465100 \\ \mathrm{H} & -1.23998900 & 2.56553700 & 0.58330400 \\ \mathrm{C} & -1.34265200 & 0.53423200 & -0.18039200 \\ \mathrm{H} & -0.56849600 & -0.00808500 & 0.38283900 \\ \mathrm{C} & -0.67667500 & 1.09279000 & -1.45761000 \\ \mathrm{H} & -1.37639300 & 1.75185900 & -1.98001800 \\ \mathrm{H} & -0.40383800 & 0.27366600 & -2.12877100 \\ \mathrm{C} & 0.56203200 & 1.89647900 & -1.13385900 \\ \mathrm{O} & 0.55893500 & 3.11461600 & -1.14032800 \\ \mathrm{C} & 1.82647400 & 1.19174000 & -0.76696700 \\ \mathrm{H} & 2.63810500 & 1.84694100 & -0.46172000 \\ \mathrm{C} & 1.99713600 & -0.13231100 & -0.81007400 \\ \mathrm{H} & 1.21149800 & -0.81789500 & -1.11537200 \\ \mathrm{C} & 3.27225000 & -0.80709000 & -0.44395500 \\ \mathrm{O} & 3.40496400 & -2.01076600 & -0.47974100 \\ \mathrm{O} & 4.23305200 & 0.04664300 & -0.08320700 \\ \mathrm{C} & 5.49261800 & -0.53383100 & 0.30901100 \\ \mathrm{H} & 6.21227800 & 0.27778600 & 0.19347300 \\ \mathrm{H} & 5.74159900 & -1.33774000 & -0.38726700 \\ \mathrm{C} & 5.43957700 & -1.02988200 & 1.73979500 \\ \mathrm{H} & 6.42502800 & -1.40248500 & 2.03468700 \\ \mathrm{H} & 4.71727600 & -1.84363400 & 1.84258900 \\ \mathrm{H} & 5.16005700 & -0.21741900 & 2.41645900 \\ & & & \end{array}$

22.TFA-a (VI)

$E(S M D / M 06-2 X / 6-31 G(D))=-1429.00990291$ au

$\mathrm{G}(\mathrm{SMD} / \mathrm{M06}-2 \mathrm{X} / 6-31 \mathrm{G}(\mathrm{D}))=-1428.671498$ au $\left(0^{\circ} \mathrm{C}, 1 \mathrm{~atm}\right)$

E (SMD/M06-2X-D3/def2-TZVP// SMD/M06-2X/6-31G(D)) = -1429.62081346 au

$\mathrm{C}$

C

$6.22689100-0.50305300-0.39924300$

$5.92853100-0.02158500-1.64985600$

C $\quad 4.51241600 \quad 0.00130600-1.75166100$

C $\quad 3.98872100 \quad-0.46627100 \quad-0.55916500$

$\begin{array}{llll}\mathrm{N} & 5.05594400 & -0.77135500 & 0.26248000\end{array}$

$\mathrm{H} \quad 7.17533700 \quad-0.68231000 \quad 0.08815300$

$\mathrm{H} \quad 6.64152600 \quad 0.28330100 \quad-2.40345400$

$\mathrm{H} \quad 3.94246600 \quad 0.32828800 \quad-2.61025100$

C $\quad 2.58734000 \quad-1.63425200 \quad 2.20374900$

C $\quad 3.88437900 \quad-0.86281900 \quad 2.46580600$

C $\quad 5.04916300 \quad-1.34879700 \quad 1.60979400$

$\mathrm{H} \quad 2.62883700 \quad-2.60096600 \quad 2.71891900$

$\mathrm{H} \quad 3.74470800 \quad 0.20926700 \quad 2.28440200$

$\mathrm{H} \quad 5.03893600 \quad-2.44378900 \quad 1.53978100$

$\mathrm{H} \quad 1.74902500 \quad-1.07860100 \quad 2.64021600$

$\mathrm{H} \quad 4.16161800 \quad-0.96744100 \quad 3.51955100$

H $\quad 5.99860900 \quad-1.05805200 \quad 2.06520300$

C $\quad 2.31491100 \quad-1.88072100 \quad 0.71720100$

$\mathrm{H} \quad 2.95596000 \quad-2.68606700 \quad 0.33718600$

$\mathrm{H} \quad 1.28429900-2.23260000 \quad 0.60209200$

C $\quad 2.54194300 \quad-0.62690500-0.14752100$

$\mathrm{H} \quad 2.23736500 \quad 0.25006000 \quad 0.44285300$

C $\quad 1.65644400 \quad-0.66525000-1.41583300$

$\mathrm{H} \quad 1.81485700 \quad-1.60939300 \quad-1.94473300$ 


$\begin{array}{lrrr}\text { H } & 1.91736400 & 0.15801600 & -2.08528000 \\ \mathrm{C} & 0.19365300 & -0.56567100 & -1.07249100 \\ \mathrm{O} & -0.50733700 & -1.57389800 & -1.05832400 \\ \mathrm{C} & -0.41768400 & 0.74112200 & -0.72360100 \\ \mathrm{H} & -1.47355400 & 0.70927800 & -0.46314200 \\ \mathrm{C} & 0.25450100 & 1.89615000 & -0.73161300 \\ \mathrm{H} & 1.30660000 & 1.96823000 & -0.99287200 \\ \mathrm{C} & -0.36879600 & 3.20324900 & -0.37926400 \\ \mathrm{O} & 0.25588100 & 4.24082700 & -0.38372900 \\ \mathrm{O} & -1.66105400 & 3.09653200 & -0.07352300 \\ \mathrm{C} & -2.33951900 & 4.31560900 & 0.29068200 \\ \mathrm{H} & -3.39511000 & 4.09519800 & 0.12718900 \\ \mathrm{H} & -2.02573200 & 5.10865000 & -0.39182400 \\ \mathrm{C} & -2.06353800 & 4.67868100 & 1.73551400 \\ \mathrm{H} & -2.64104200 & 5.56786800 & 2.00512400 \\ \mathrm{H} & -1.00319100 & 4.89642700 & 1.88647500 \\ \mathrm{H} & -2.35790600 & 3.86041000 & 2.39864400 \\ \mathrm{C} & -3.86676400 & -1.21238300 & -0.24910300 \\ \mathrm{O} & -3.65784200 & -0.02698200 & -0.29362100 \\ \mathrm{O} & -3.01496900 & -2.19017700 & -0.43879800 \\ \mathrm{C} & -5.25739700 & -1.77869000 & 0.07771600 \\ \mathrm{~F} & -6.15525400 & -0.80332800 & 0.14968200 \\ \mathrm{~F} & -5.64573100 & -2.64956400 & -0.85610200 \\ \mathrm{~F} & -5.22764400 & -2.41741200 & 1.25157700 \\ \mathrm{H} & -2.10351500 & -1.83228500 & -0.65072400\end{array}$

22.TFA-b (VII)

$\mathrm{E}(\mathrm{SMD} / \mathrm{M06}-2 \mathrm{X} / 6-31 \mathrm{G}(\mathrm{D}))=-1429.01453723 \mathrm{au}$

$\mathrm{G}(\mathrm{SMD} / \mathrm{M06}-2 \mathrm{X} / 6-31 \mathrm{G}(\mathrm{D}))=-1428.672071 \mathrm{au}\left(0^{\circ} \mathrm{C}, 1 \mathrm{~atm}\right)$

E (SMD/M06-2X-D3/def2-TZVP// SMD/M06-2X/6-31G(D)) =-1429.62327484 au

C

$\begin{array}{lll}-3.97163900 & 0.65034400 & -0.75391600\end{array}$

$\mathrm{C}$

$\begin{array}{lll}-3.32250100 & 1.48675600 & 0.11963800\end{array}$

C

$-2.26446800$

0.73416500

0.69636600

$-2.30050800$

$-0.54044400$

0.15629400

$-3.35376000$

$-0.57483800$

$-0.73533900$

$-4.82577600$

0.81455400

$-1.39625600$

$-3.56700000$

2.52112900

0.31722400

$-1.55936300$

1.09383600

1.43260000

$-2.25561500$

$-3.62917100$

$-1.04758000$

$-2.72499400$

$-2.58900300$

$-2.06940500$

$-3.84362500$

$-1.69661100$

$-1.54104400$

$-2.96849700$

$-4.46162500$

$-1.02213600$

$-1.89268900$

$-1.94899700$

$-2.38498900$

$-4.55750800$

$-2.28788100$

$-0.95397100$

$-1.29653000$

$-4.04453600$

$-1.37896900$

$-3.08401600$

$-3.09994700$

$-2.96849700$

$-4.39328100$

$-1.24991800$

$-2.37258400$

$-2.10436900$

$-3.06736500$

0.36853600

$-3.08699300-2.94671200$

$-1.55585200-3.79174800$

0.84203700

$-1.37634700-1.71142200$

0.98041700

C

$-0.60675300$

$-1.72551200$

0.40715300

$-0.65807700$

$-1.53287100$

$-0.37999000$

C

1.76525300

S-43 


$\begin{array}{lrrr}\mathrm{H} & -1.34069500 & -1.79842200 & 2.57774400 \\ \mathrm{H} & -0.34194600 & -0.49619500 & 1.90671400 \\ \mathrm{C} & 0.55529900 & -2.42998200 & 1.85425400 \\ \mathrm{O} & 0.53573700 & -3.50269800 & 2.42857800 \\ \mathrm{C} & 1.82626500 & -1.99173800 & 1.19602400 \\ \mathrm{H} & 2.67438500 & -2.65799400 & 1.33114700 \\ \mathrm{C} & 1.93121900 & -0.86127300 & 0.49342000 \\ \mathrm{H} & 1.09046800 & -0.19041200 & 0.35430300 \\ \mathrm{C} & 3.18948300 & -0.39049600 & -0.12898500 \\ \mathrm{O} & 3.27797200 & 0.69942300 & -0.68220100 \\ \mathrm{O} & 4.19791900 & -1.23250600 & -0.02579700 \\ \mathrm{C} & 5.46129700 & -0.82996000 & -0.60913000 \\ \mathrm{H} & 6.19625700 & -1.45401800 & -0.10056400 \\ \mathrm{H} & 5.63985400 & 0.21788000 & -0.36032600 \\ \mathrm{C} & 5.46239000 & -1.06733300 & -2.10450600 \\ \mathrm{H} & 6.44992000 & -0.82343200 & -2.50672200 \\ \mathrm{H} & 4.72145100 & -0.43698300 & -2.60236700 \\ \mathrm{H} & 5.24769900 & -2.11626800 & -2.32632400 \\ \mathrm{C} & 0.65907000 & 2.59652500 & 0.28899900 \\ \mathrm{O} & 0.86263100 & 2.00825700 & 1.32153200 \\ \mathrm{O} & 1.29335000 & 2.46005800 & -0.85033500 \\ \mathrm{C} & -0.41893200 & 3.68693000 & 0.17418100 \\ \mathrm{~F} & -1.23050100 & 3.65670800 & 1.22716100 \\ \mathrm{~F} & 0.16413800 & 4.89007100 & 0.12673600 \\ \mathrm{~F} & -1.14481700 & 3.53779800 & -0.93285400 \\ \mathrm{H} & 2.02924600 & 1.78329400 & -0.75803400\end{array}$




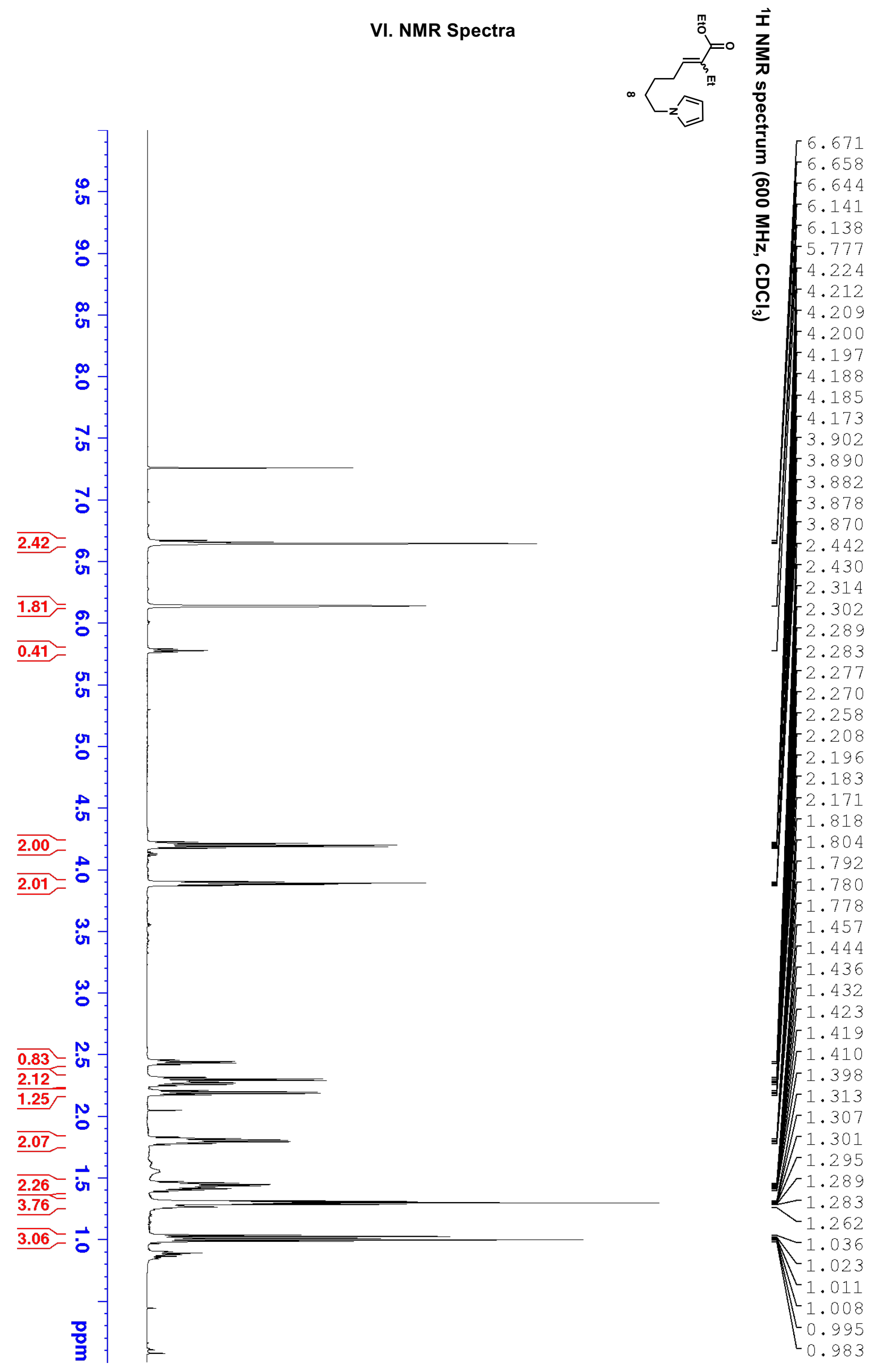



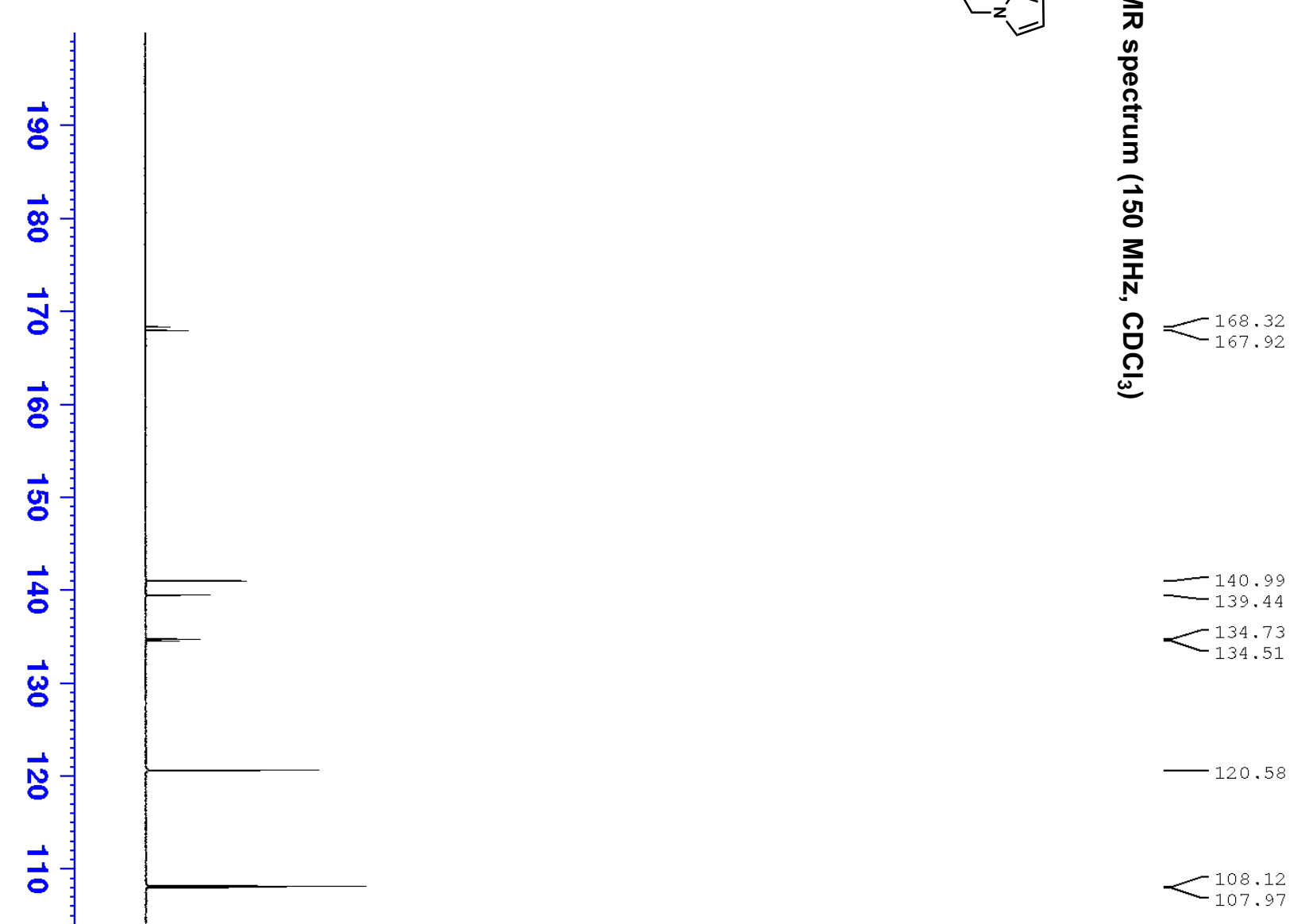

a

8

ळ

o

8

g 


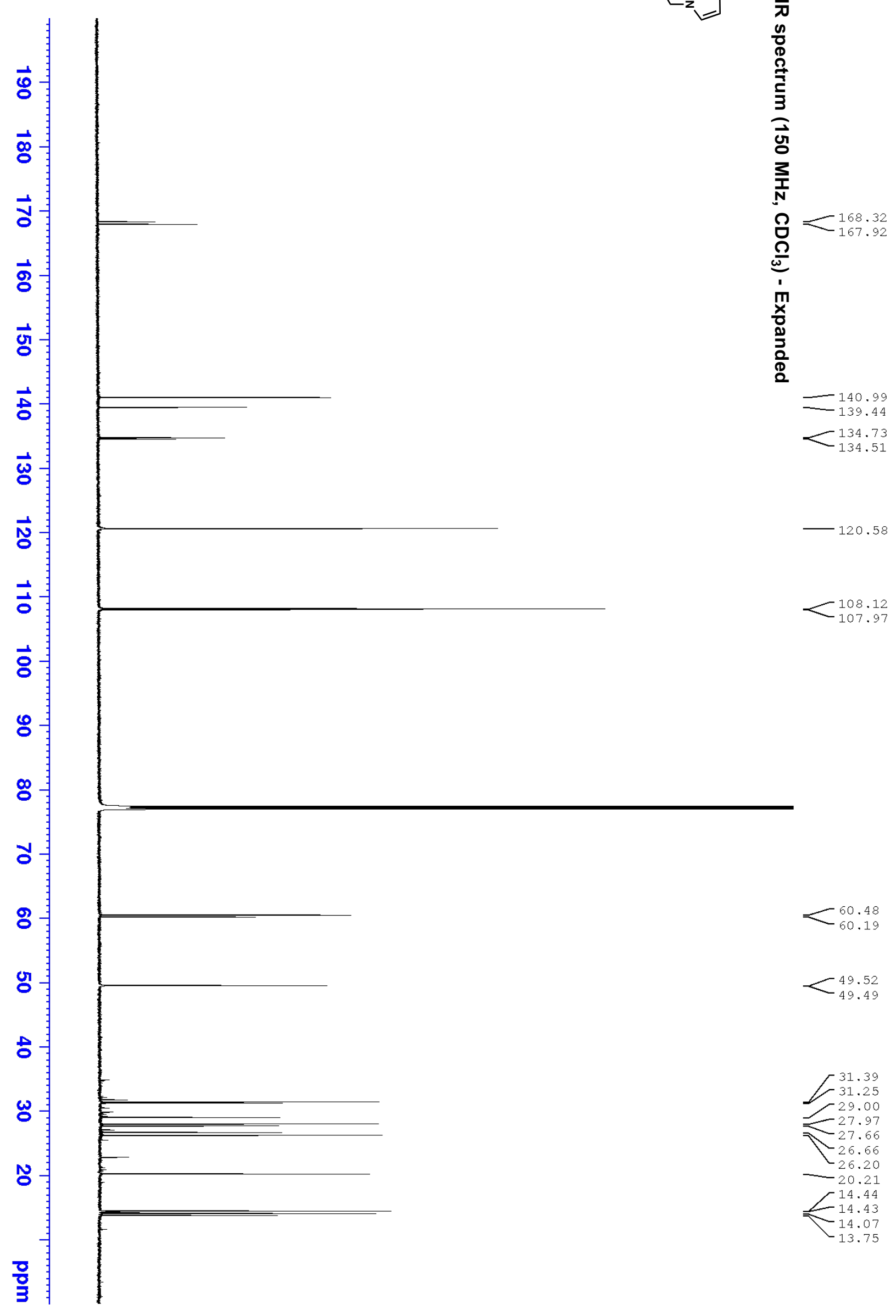




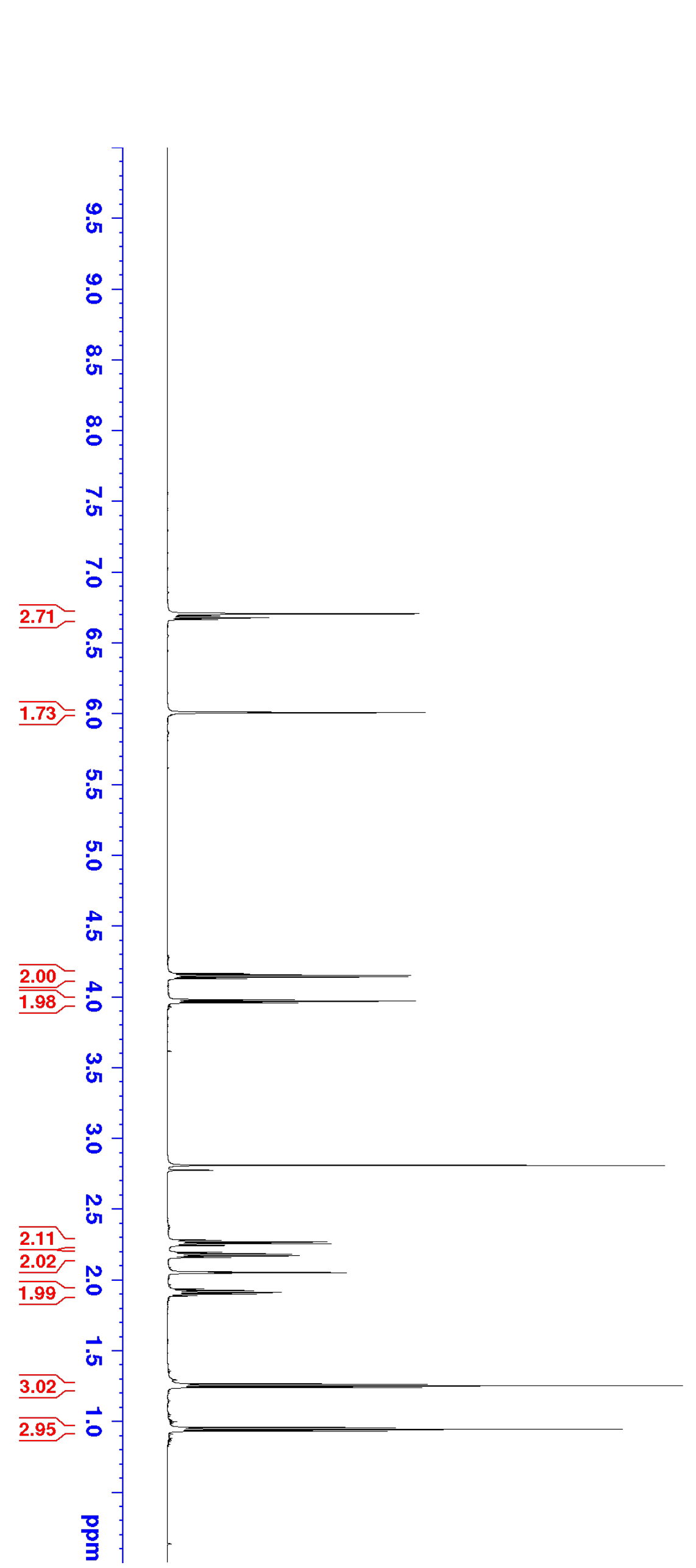

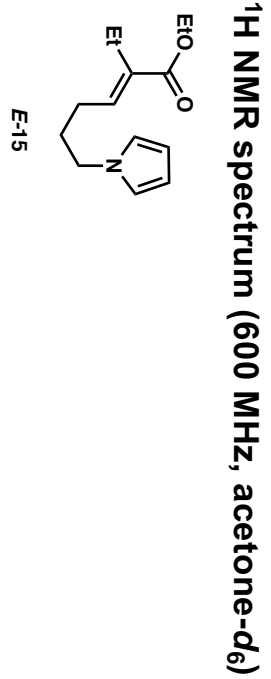

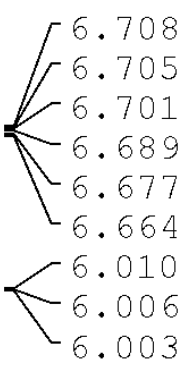

4.162
4.150
$\mathbf{R}$
4.138
4.127

$\mathbb{N} 3.979$

3.967

3.956

2.278

2.266

r 2.253

[ 2.241

- 2.193

2.181

2.168

2.155

$-1.934$

1.922

1.909

1.897

$L_{1.885}$

1.261

$u^{-1.250}$

${ }_{1.238}$

$-0.954$

0.942

0.929 


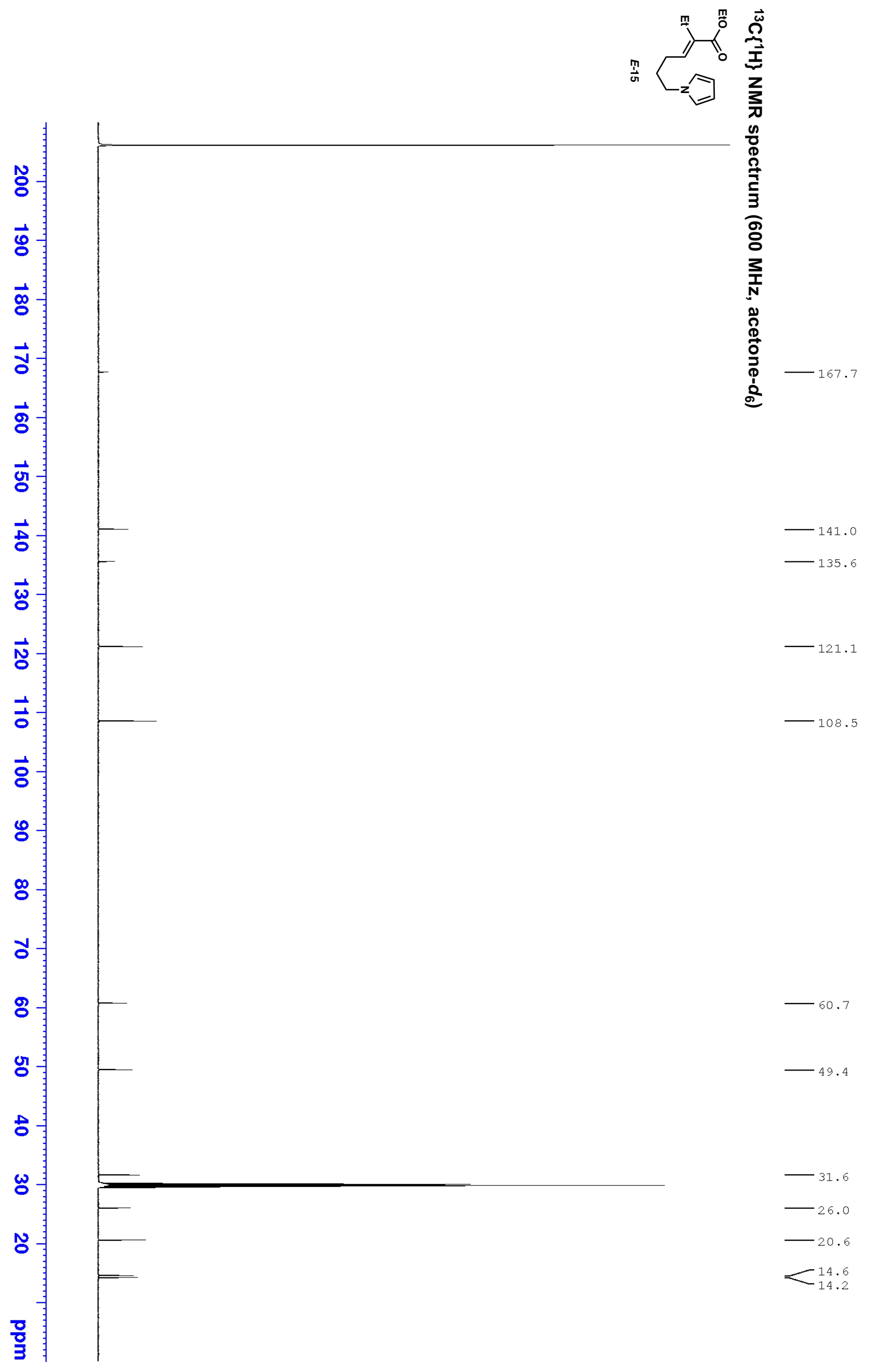




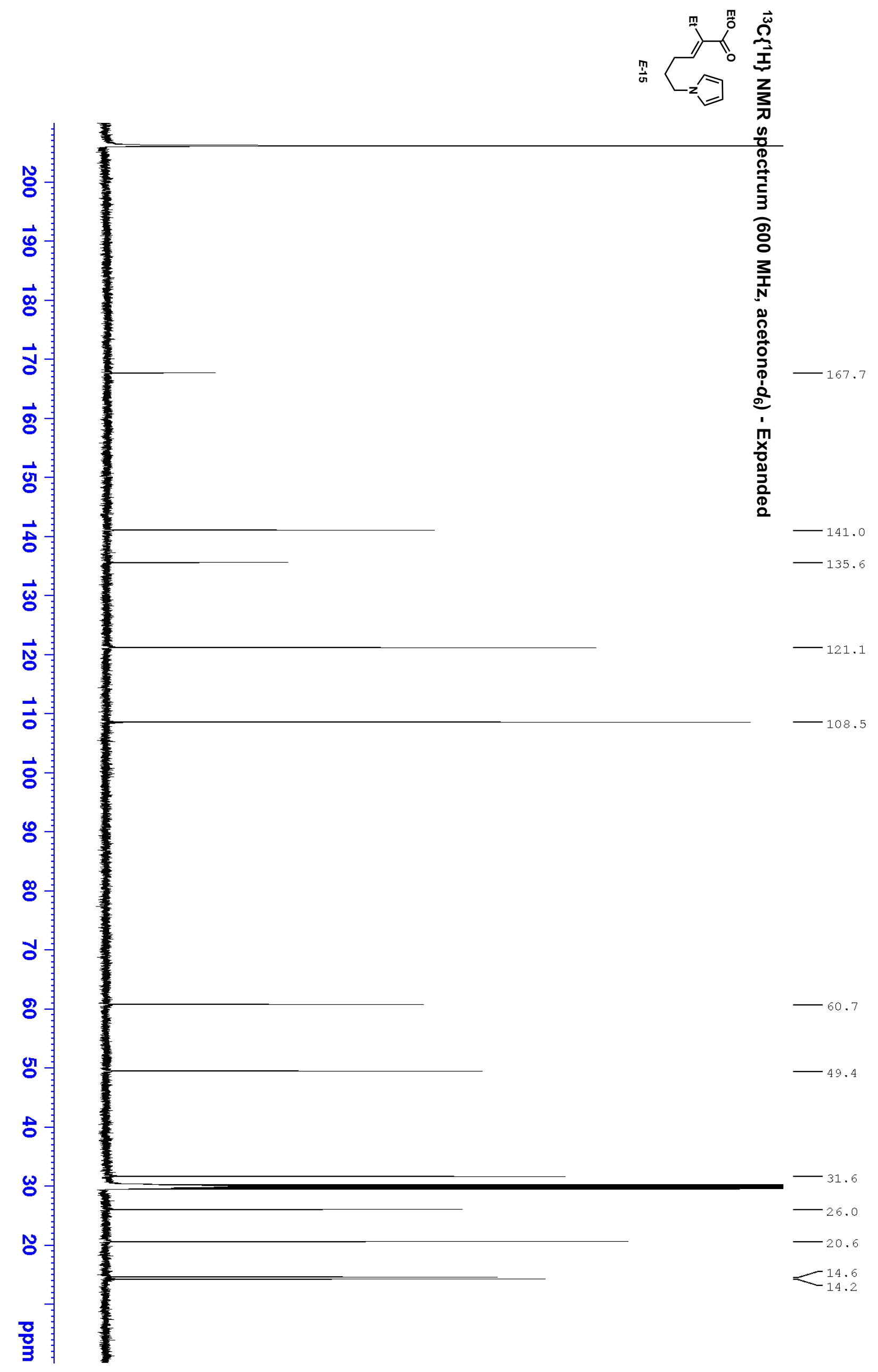




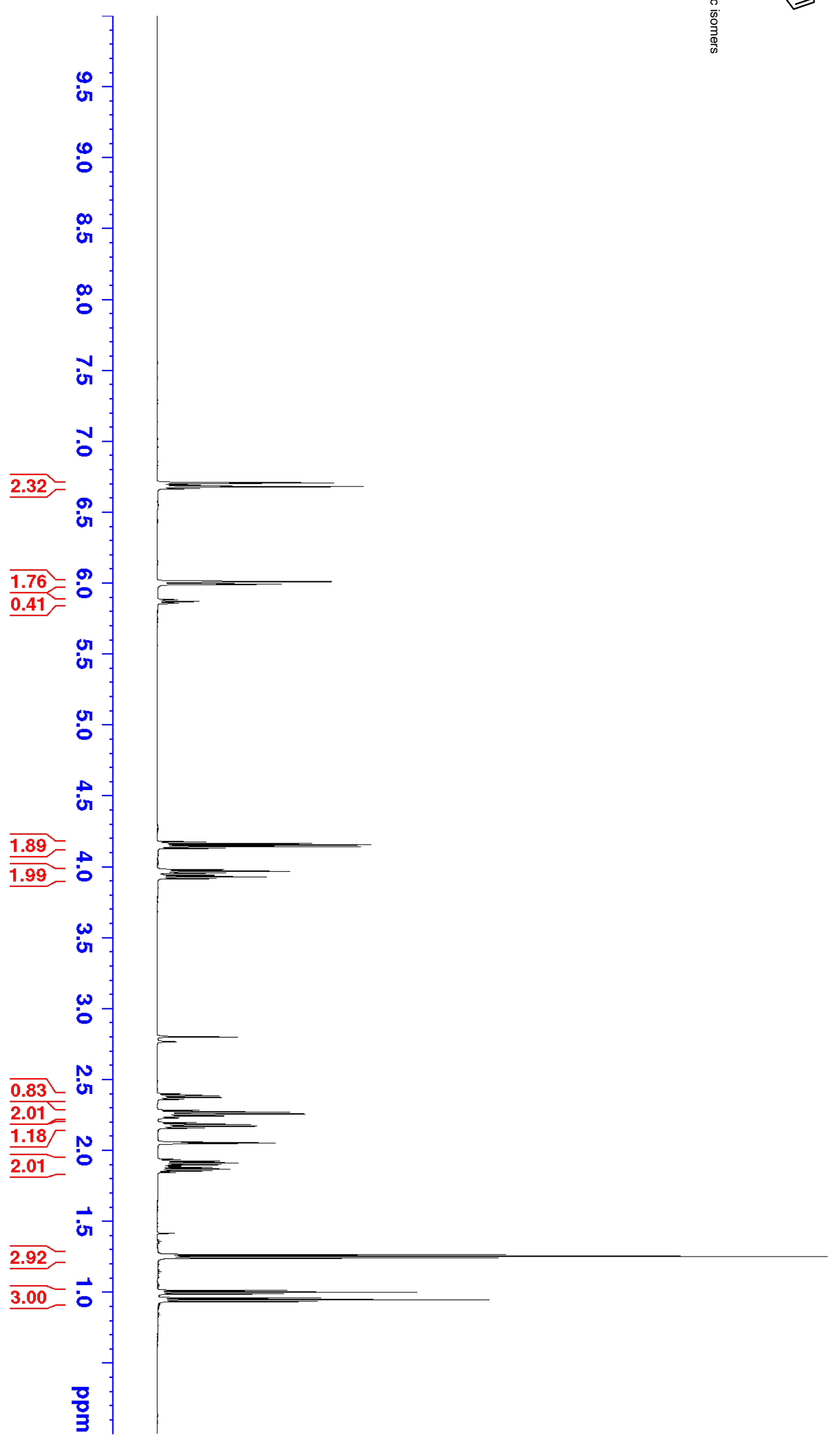

$\left[\begin{array}{l}6.708 \\ -6.704 \\ 6.701\end{array}\right.$

6.701

6.691

6.682

6.679

6.676

6.666

6.012

6.009

6.006

5.995

$-5.991$

5.988

$-5.869$

4.173

4.163

4.161

4. 152

4.149

4.140

4.138

4.128

$-3.977$

3.966

3.954

3.938

3.926

3.915

2.384

$-2.371$

2.280

2.268

2.263

2.255

2.251

2.242

2.240

2.239

2.193

2.181

2.168

2.155

1.922

$\int 1.909$

1.897

1.878

$-1.866$

1.854

$\begin{array}{r}1.262 \\ \leftarrow 1.251 \\ \hline\end{array}$

1.239

- 1.010

0.998

0.985

0.957

0.944

0.932 


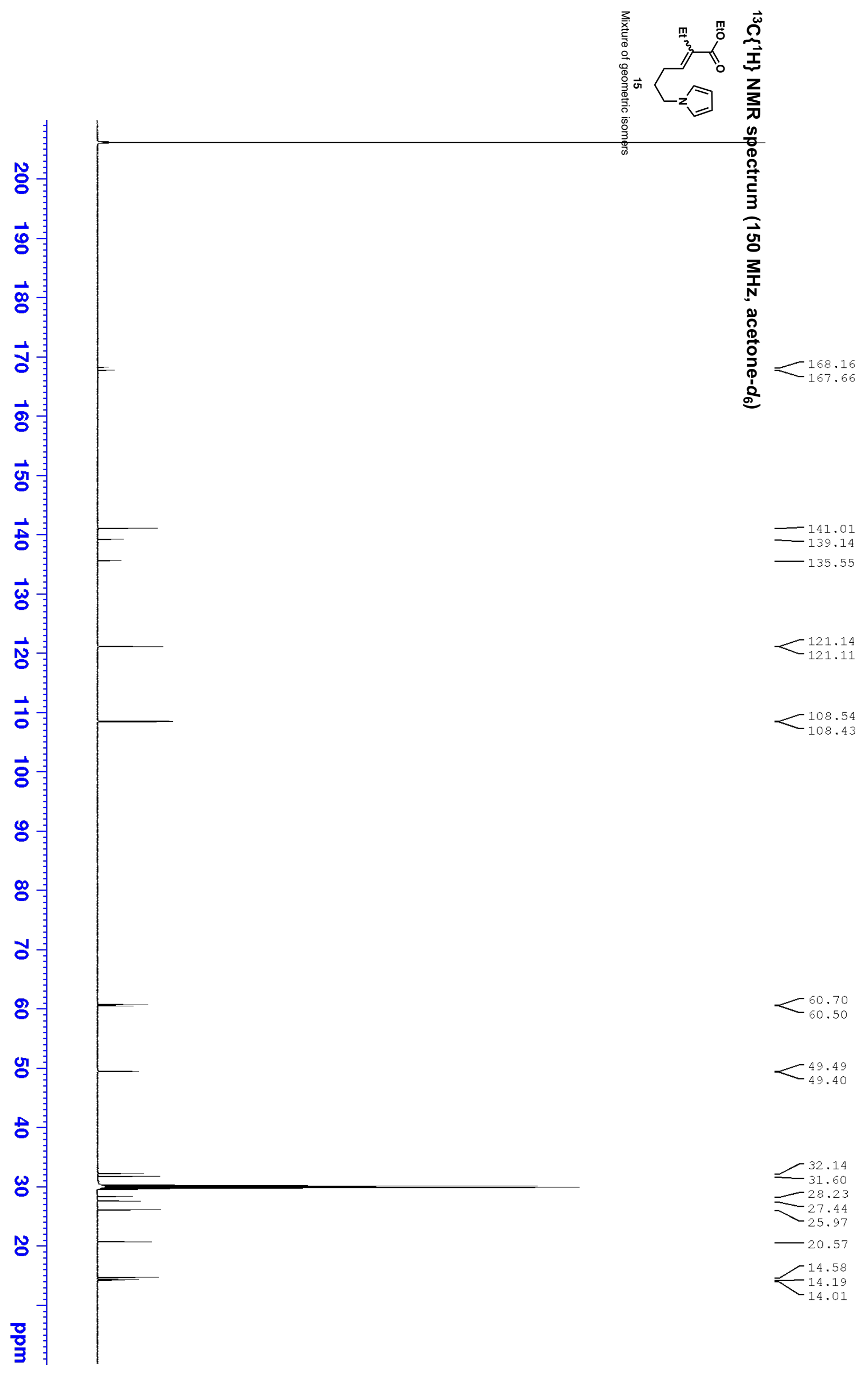




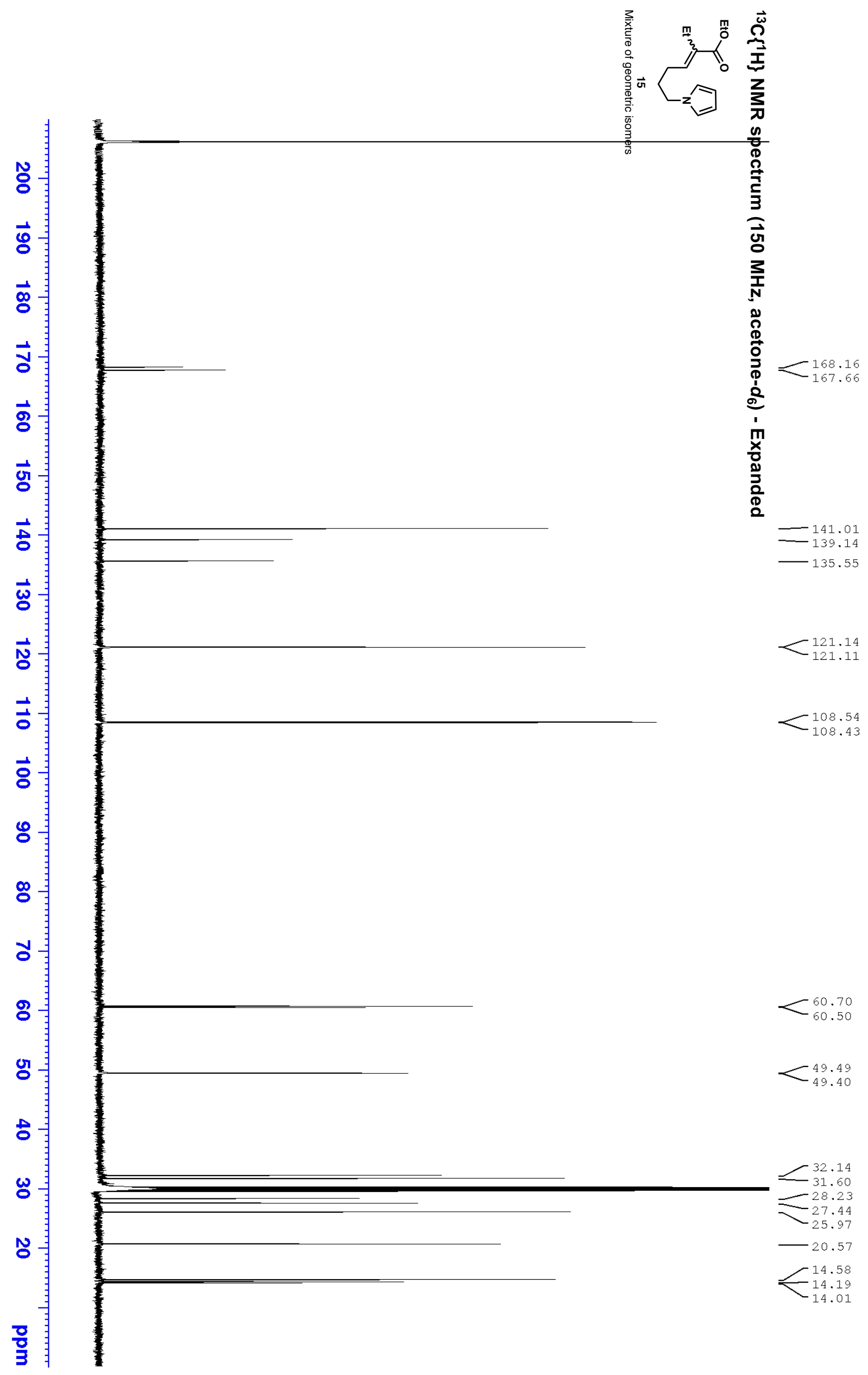




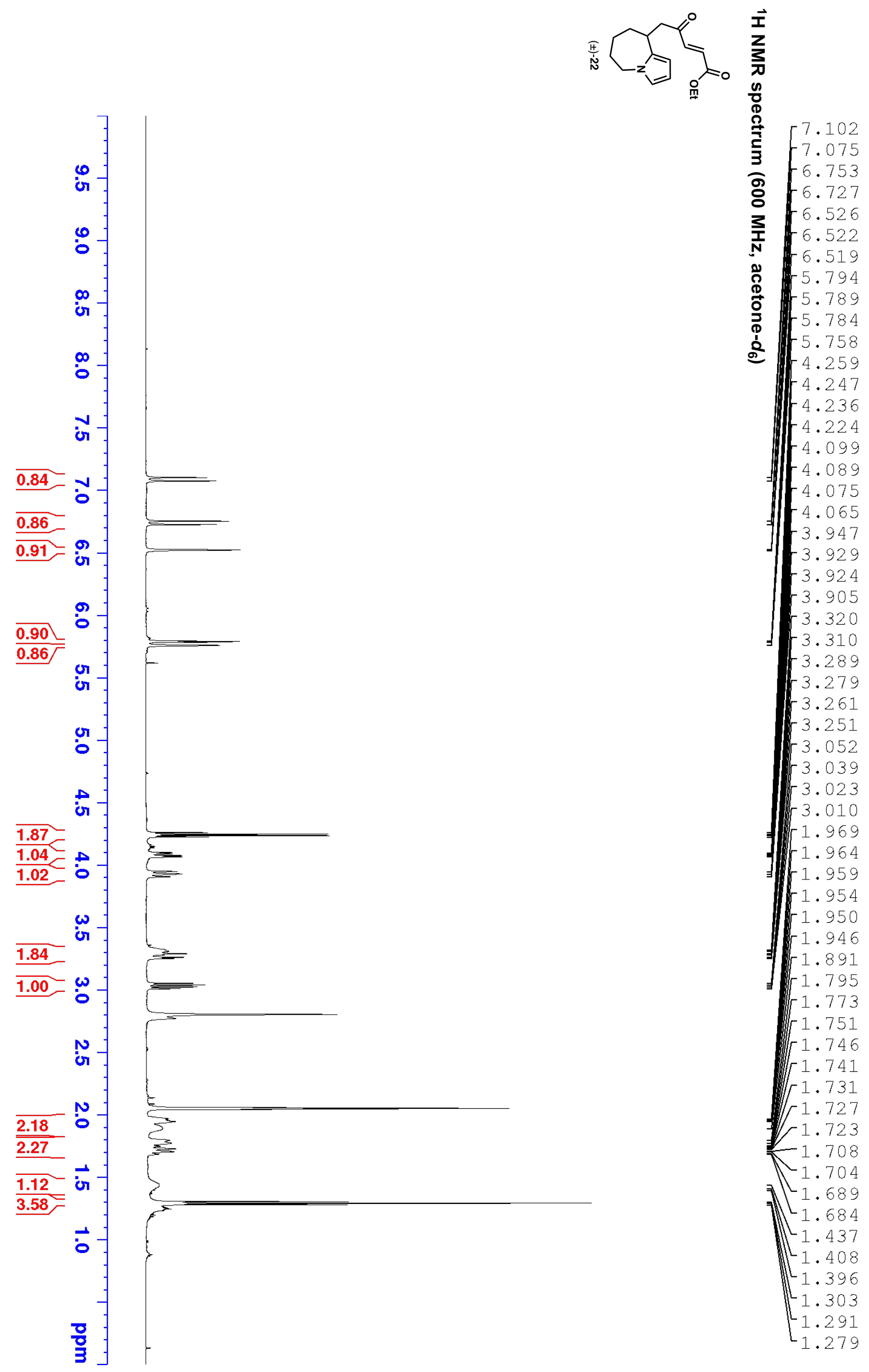




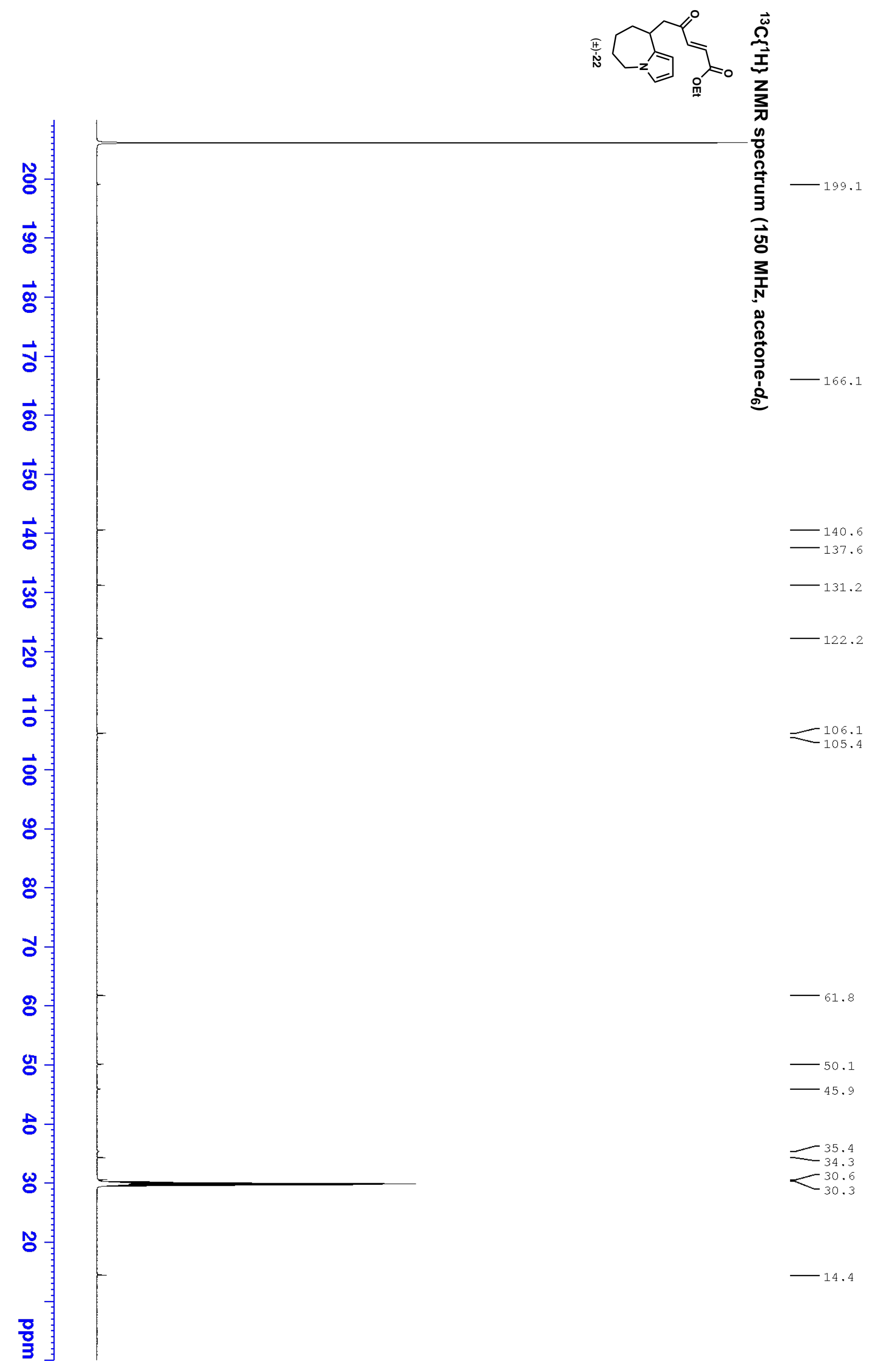




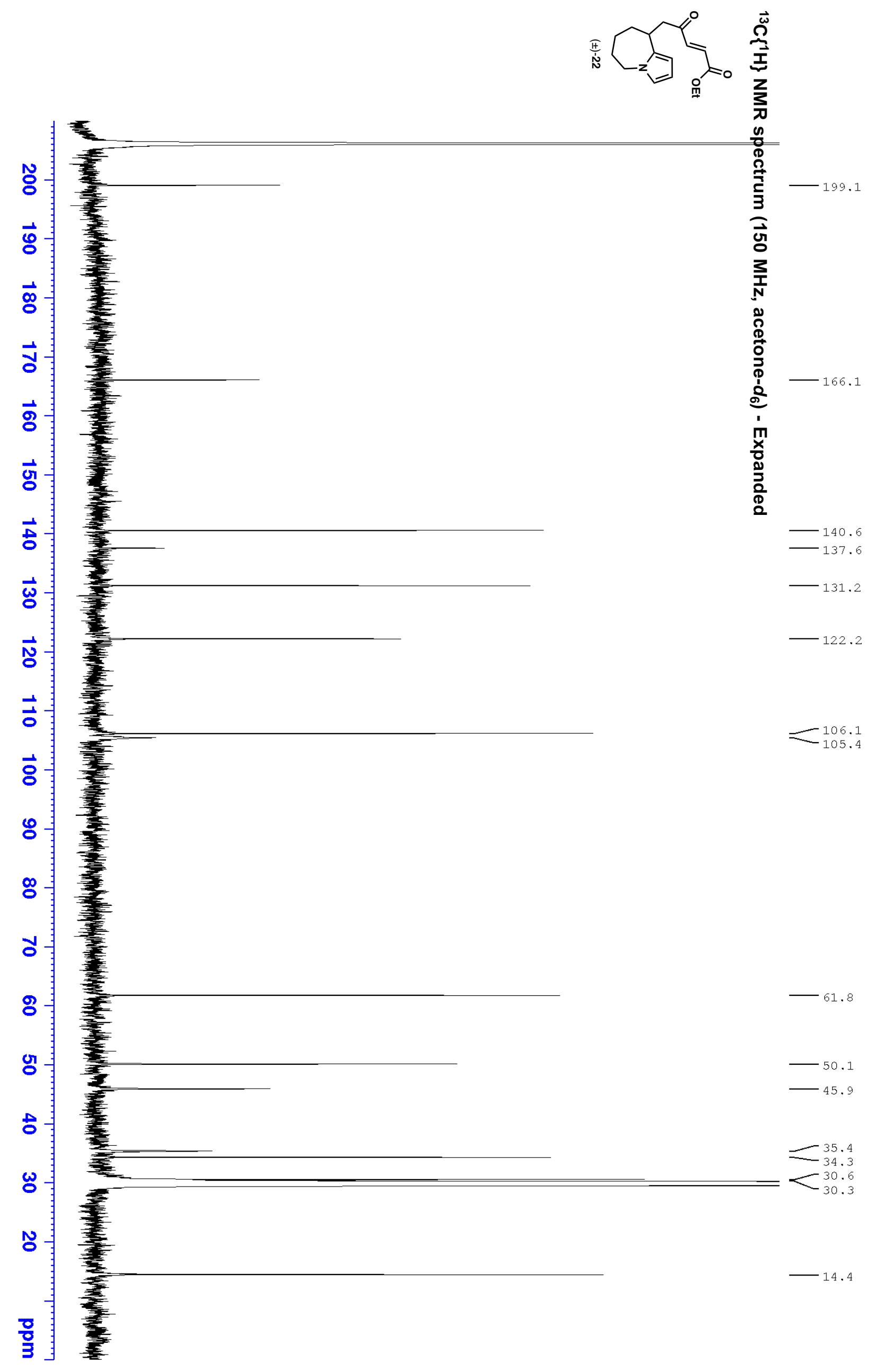




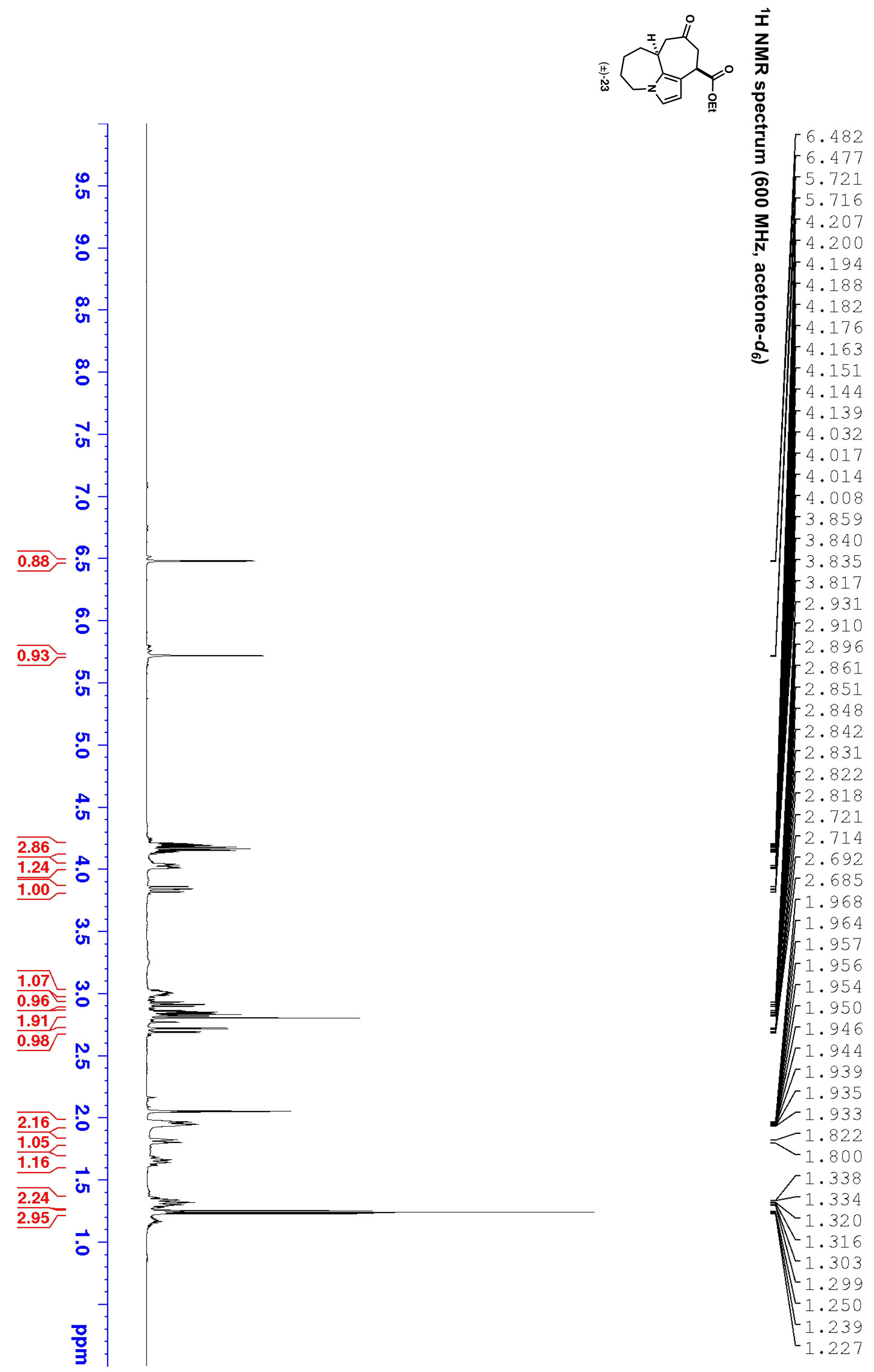




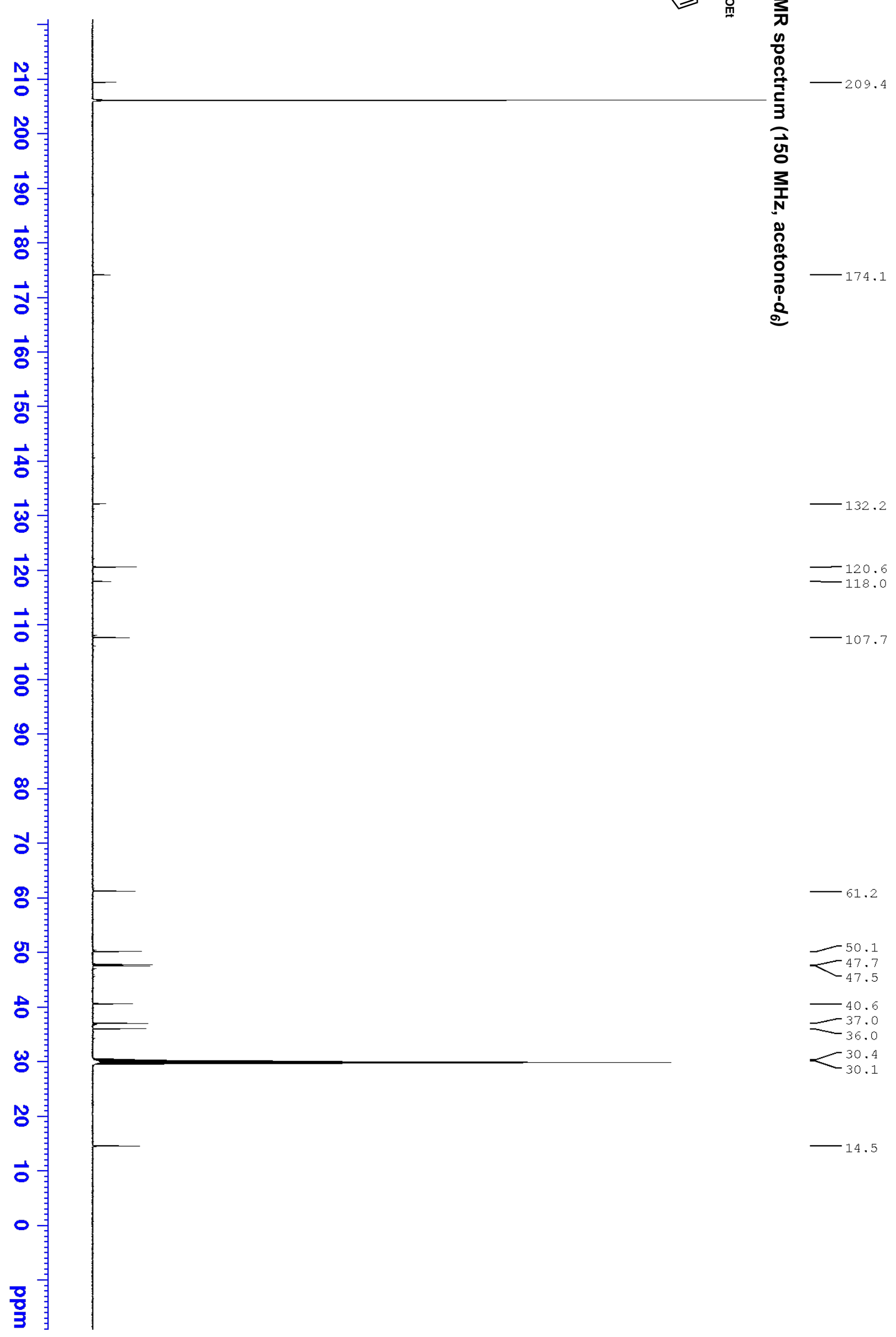




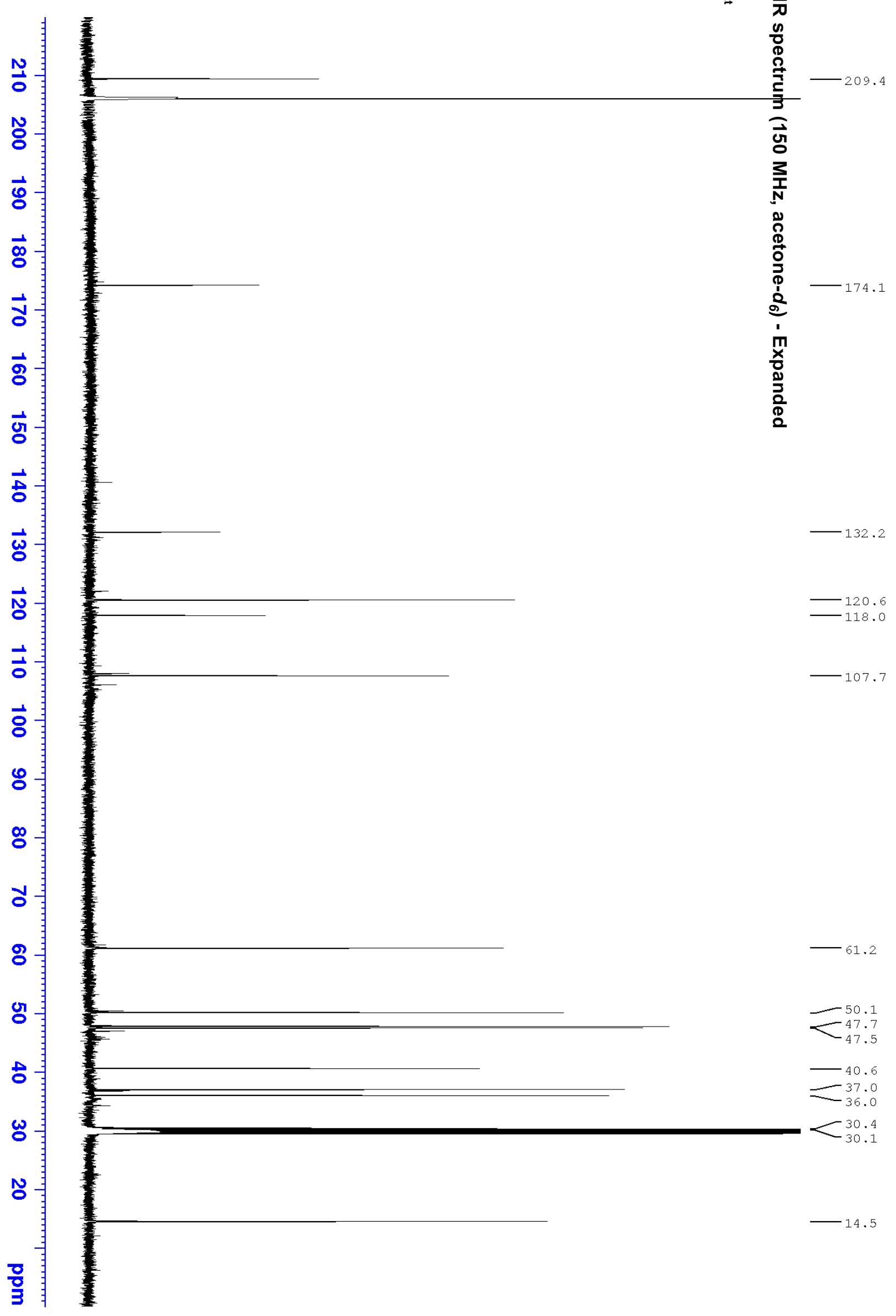




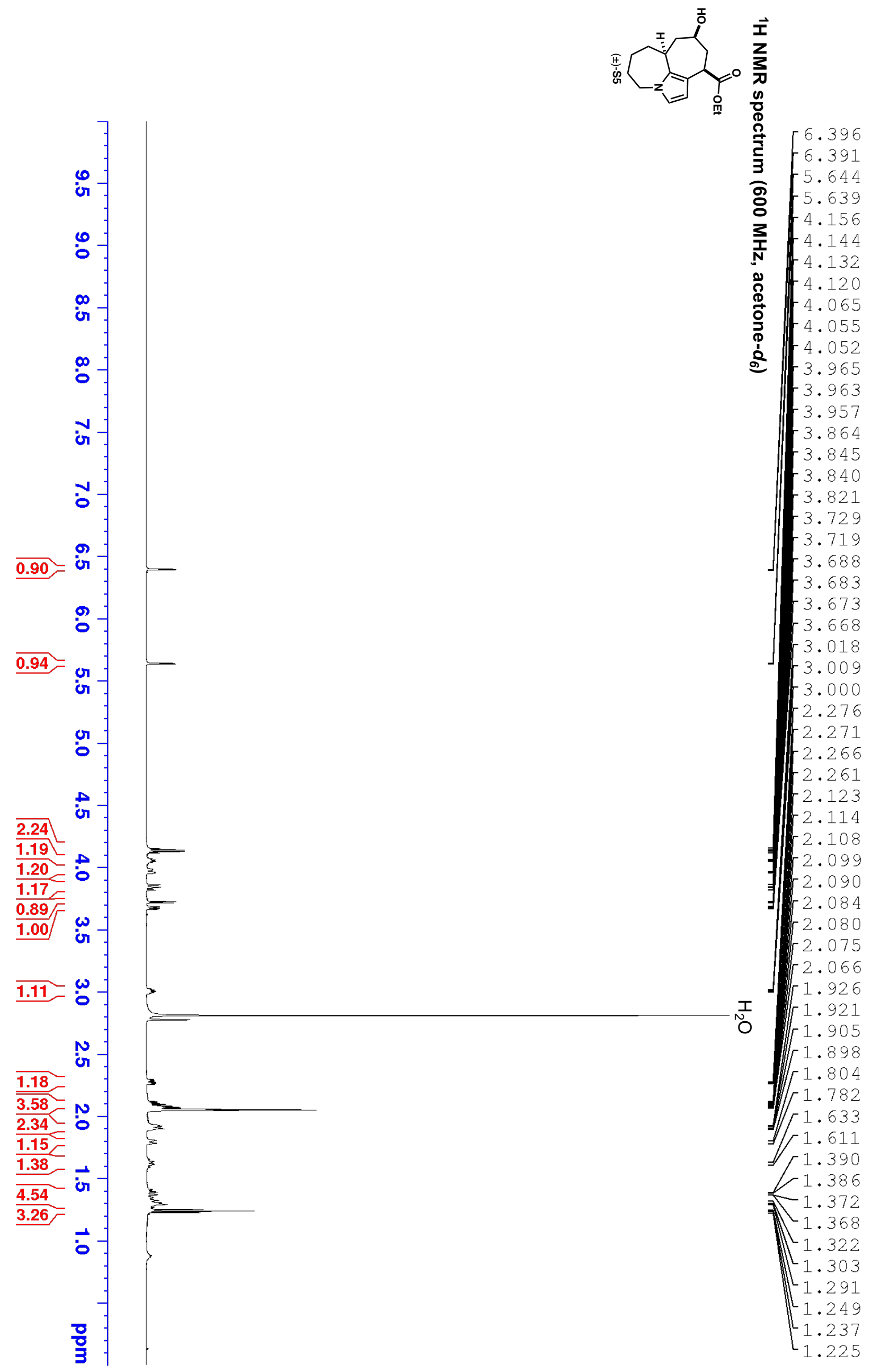




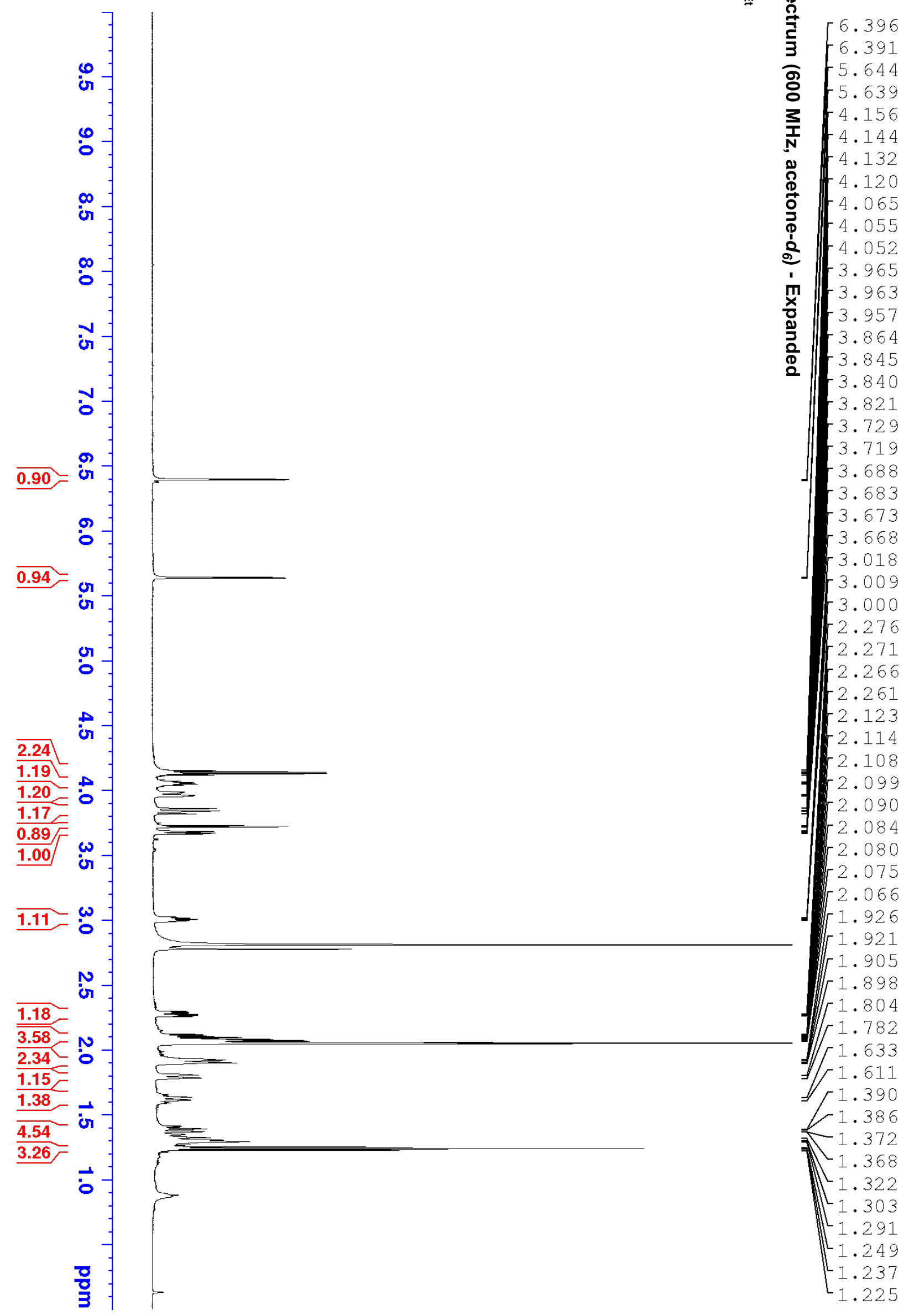




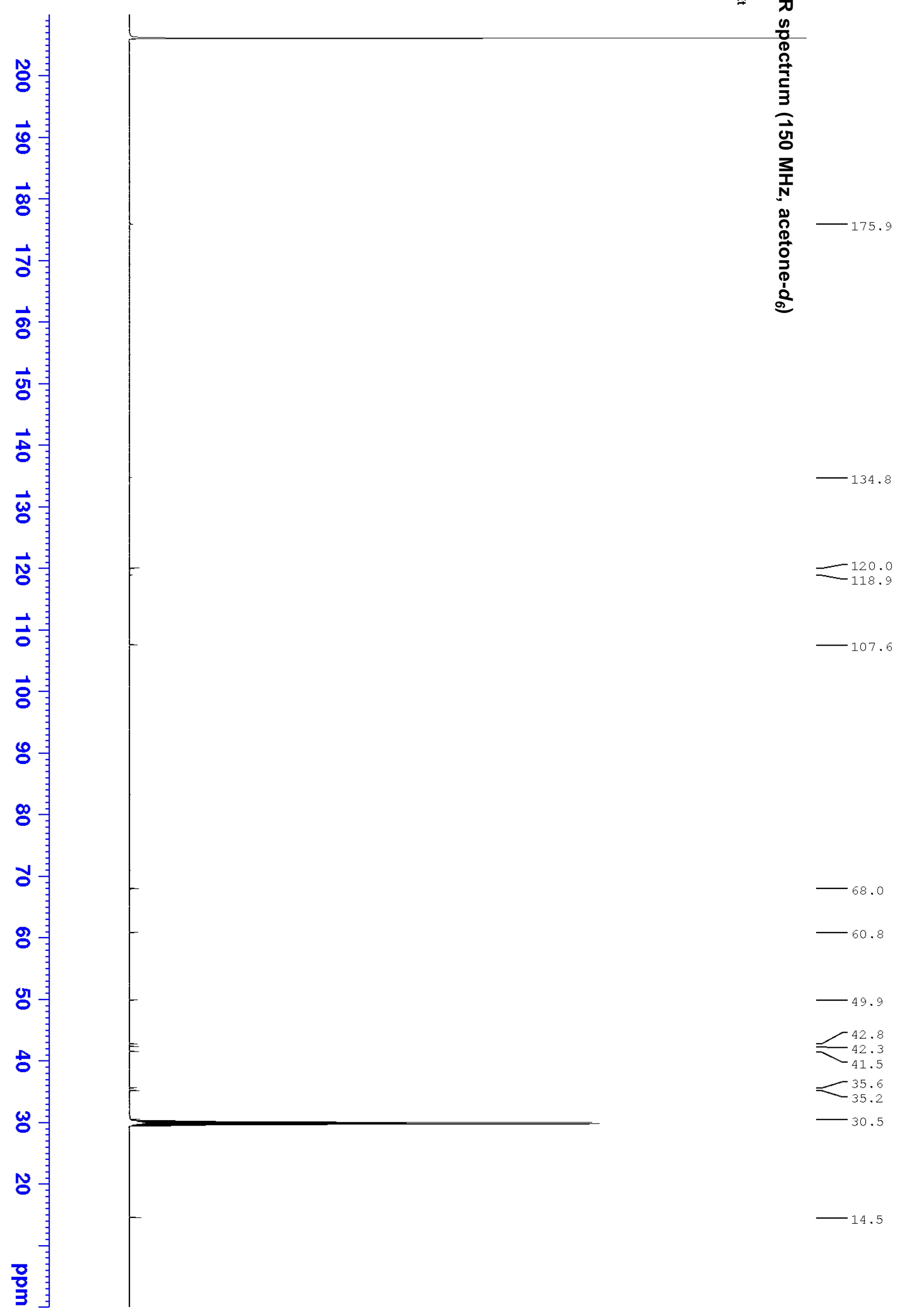




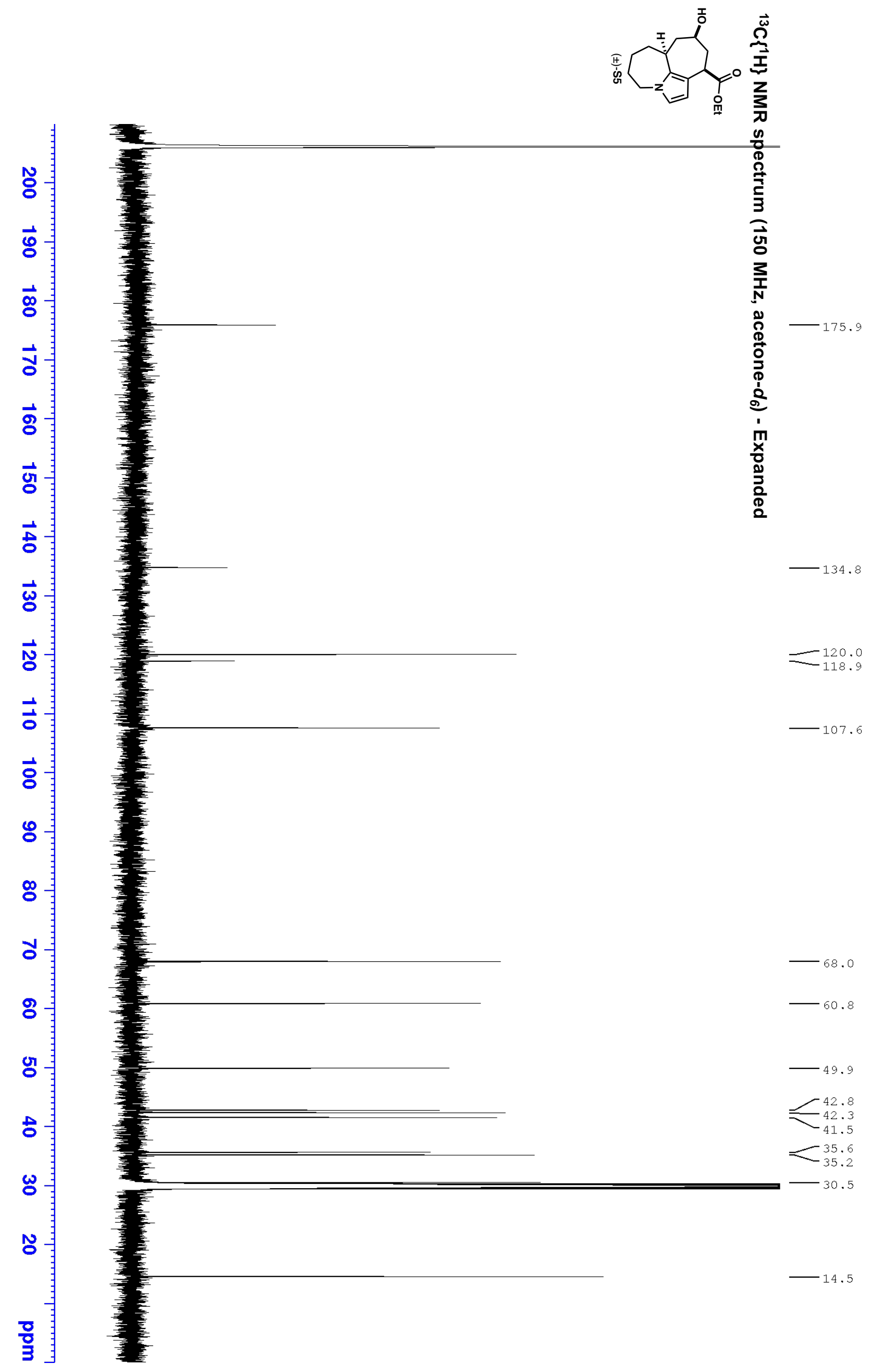



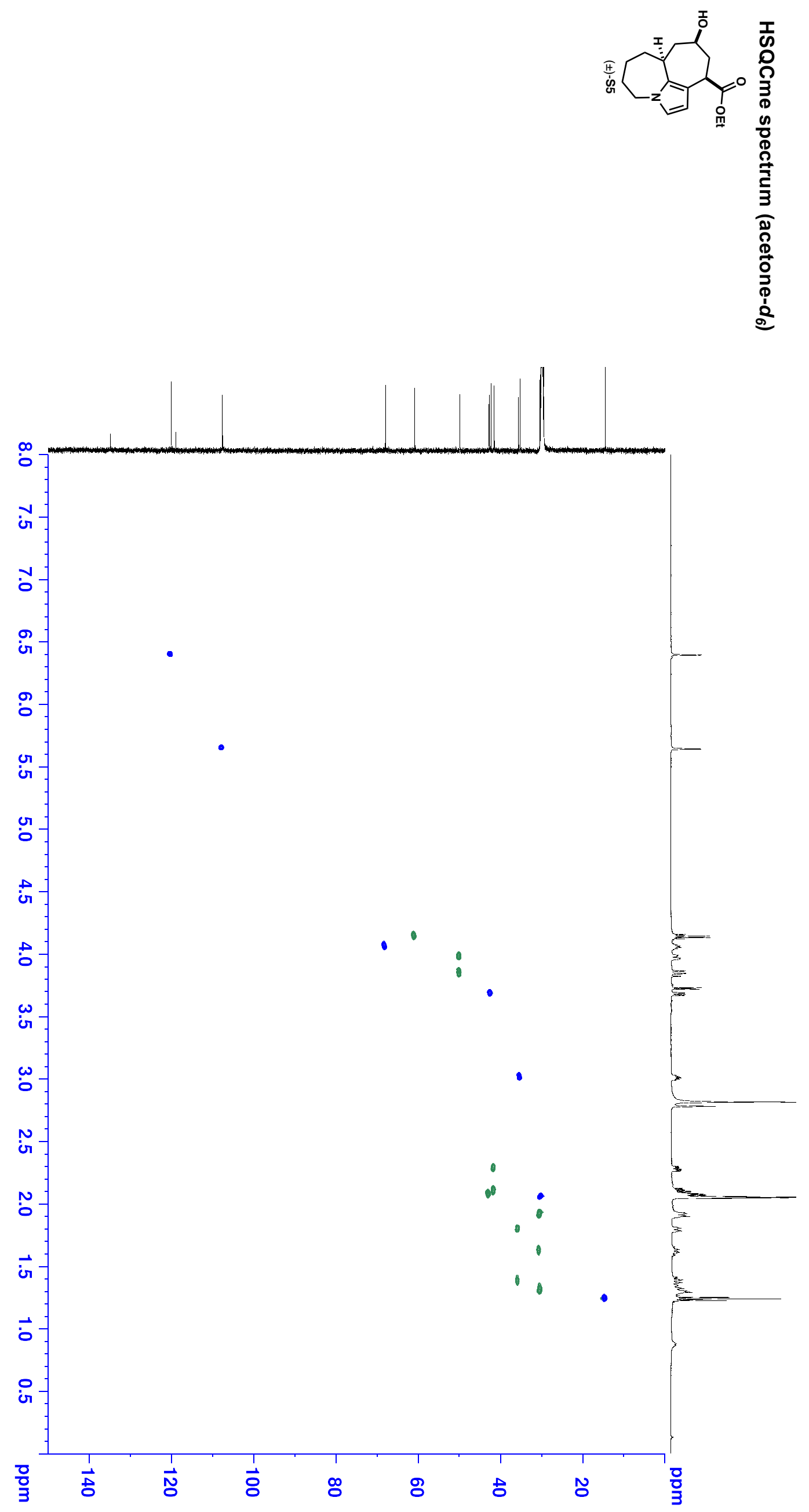


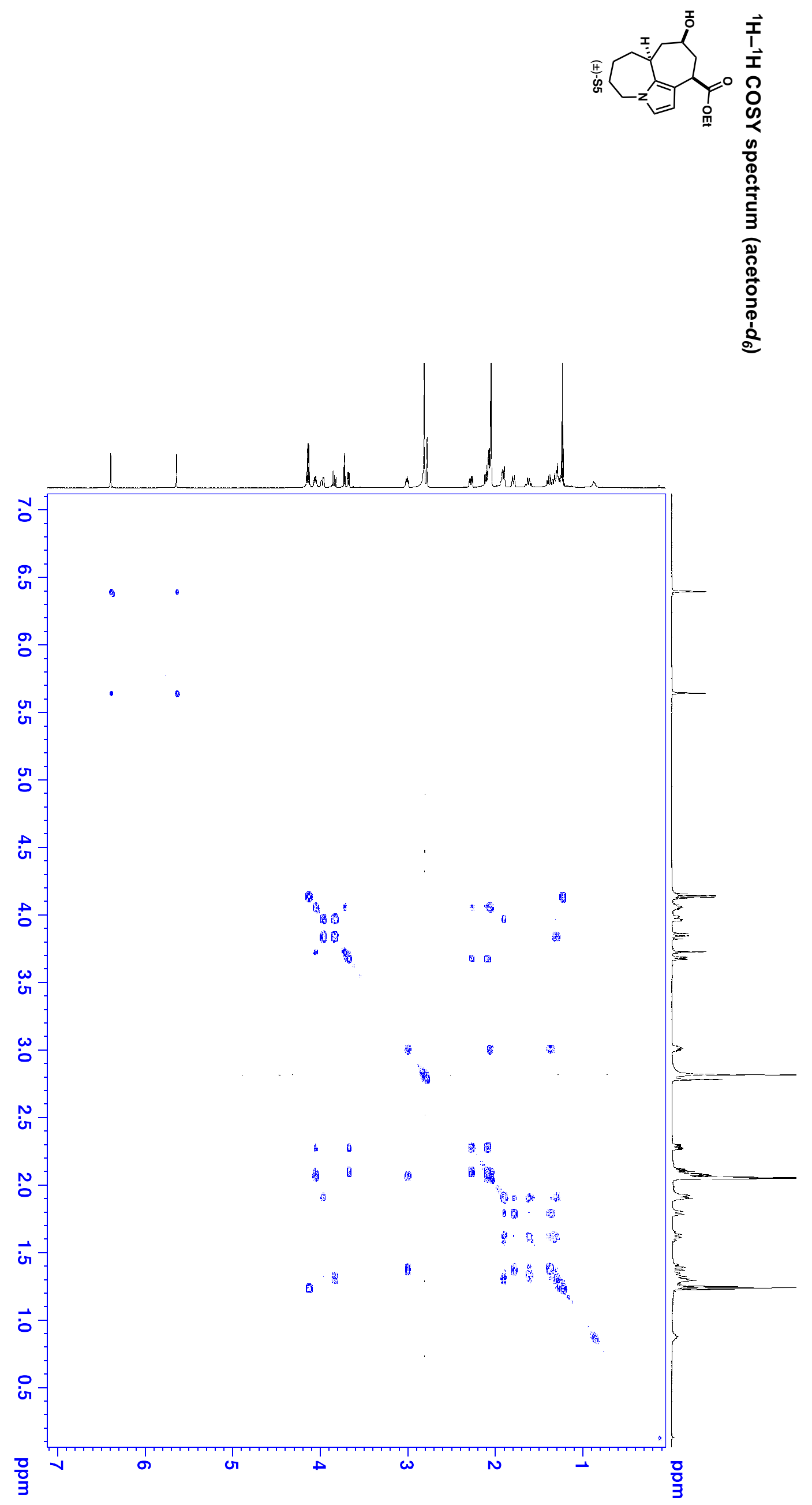



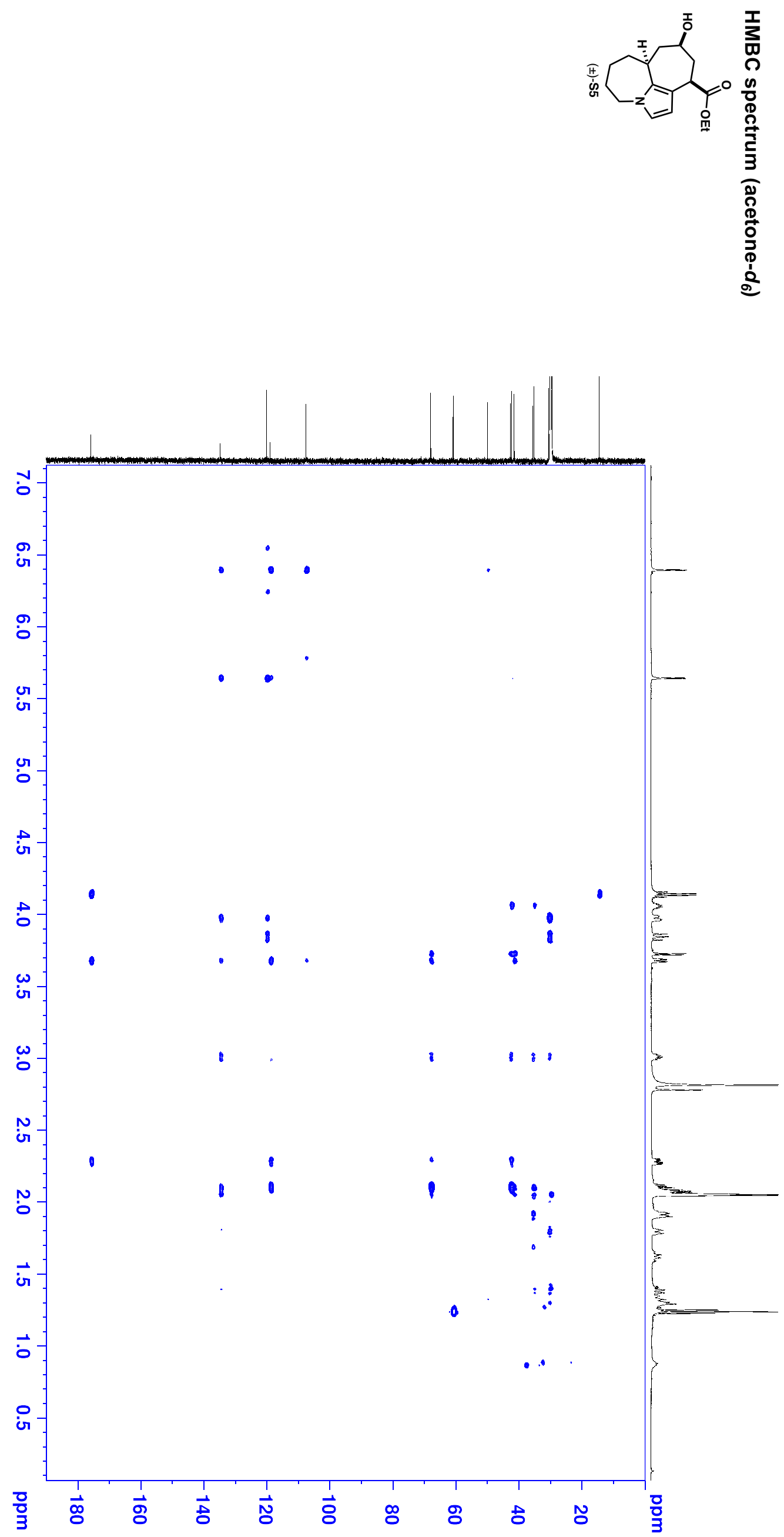

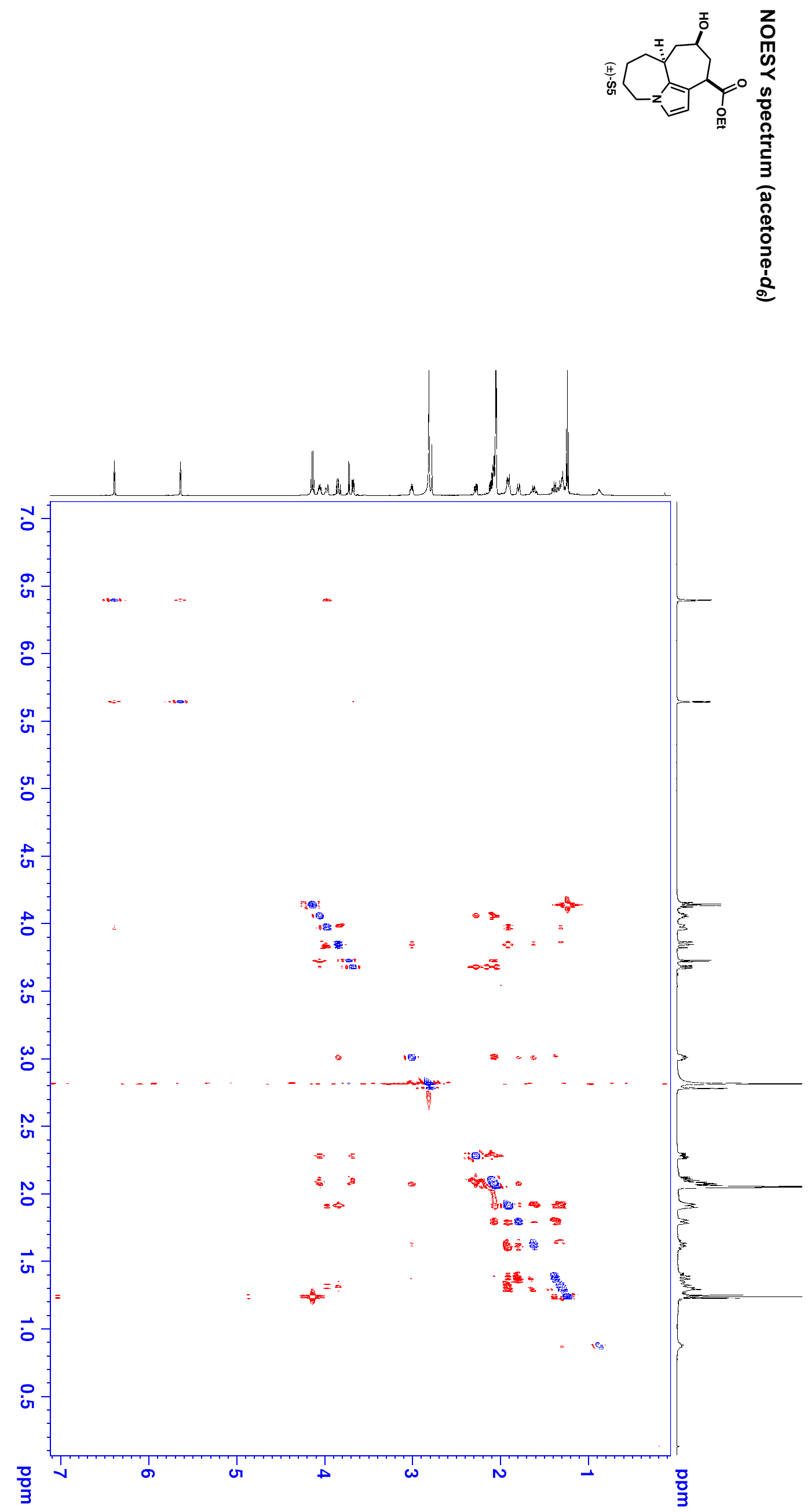


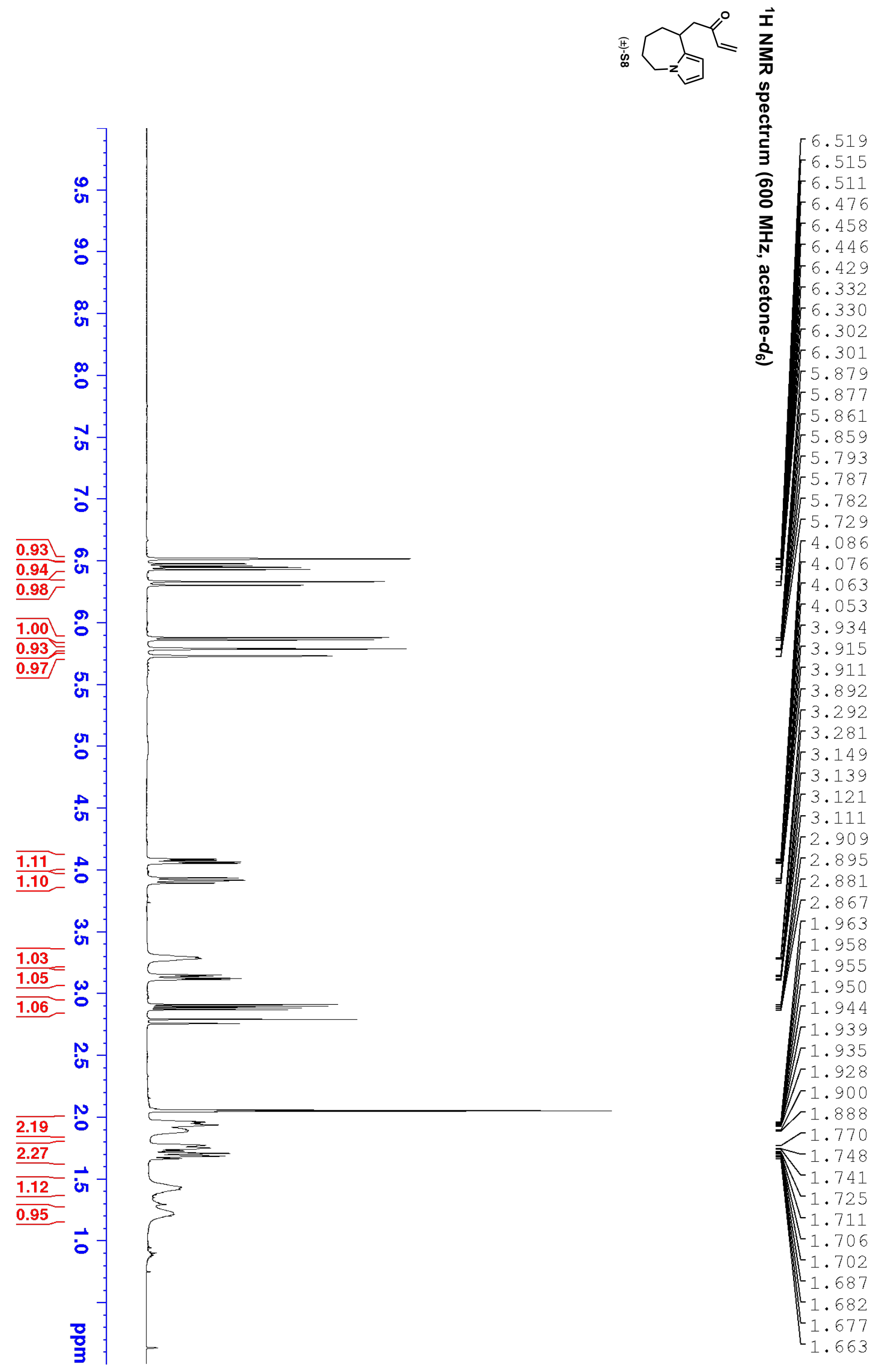




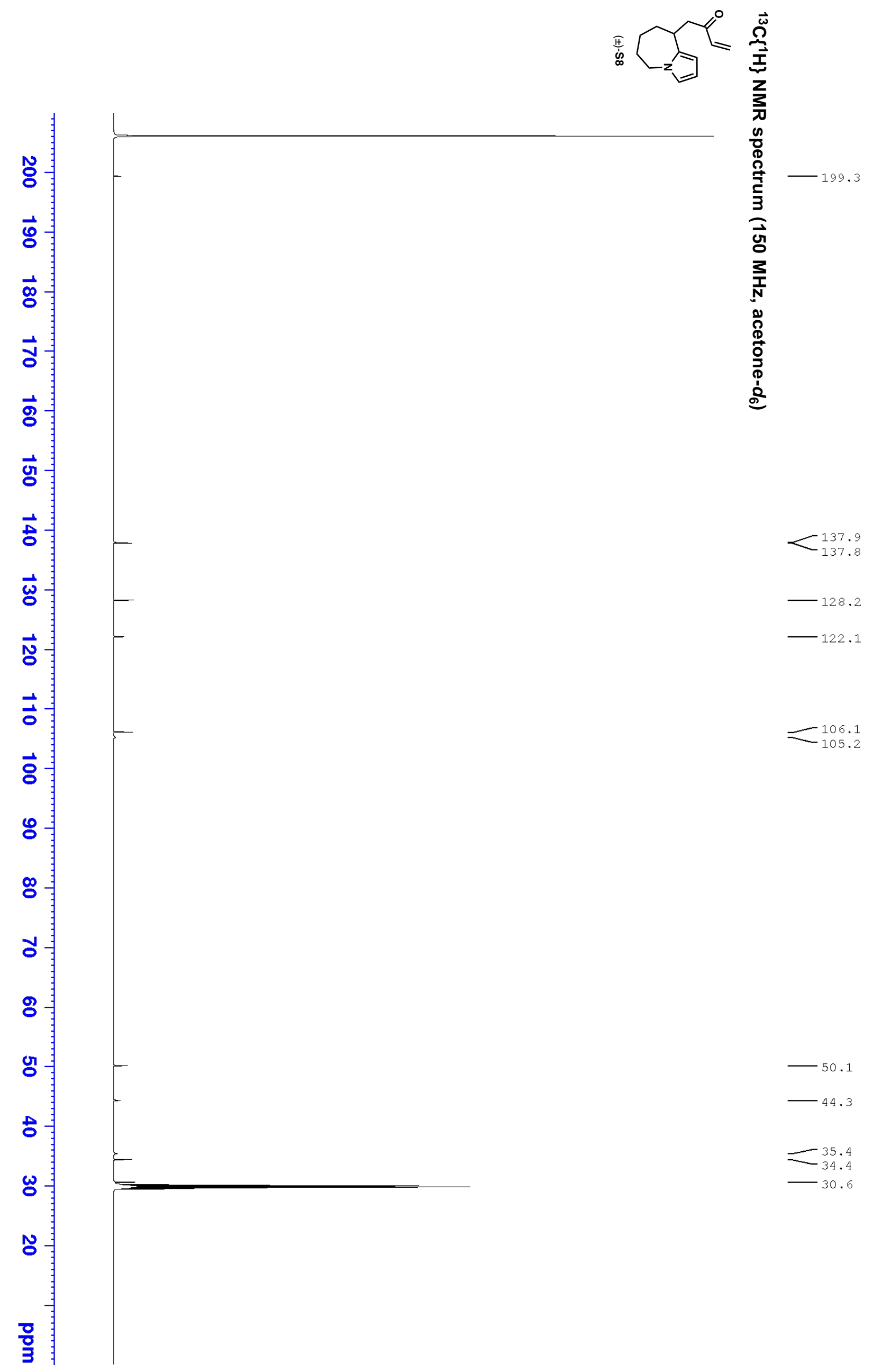




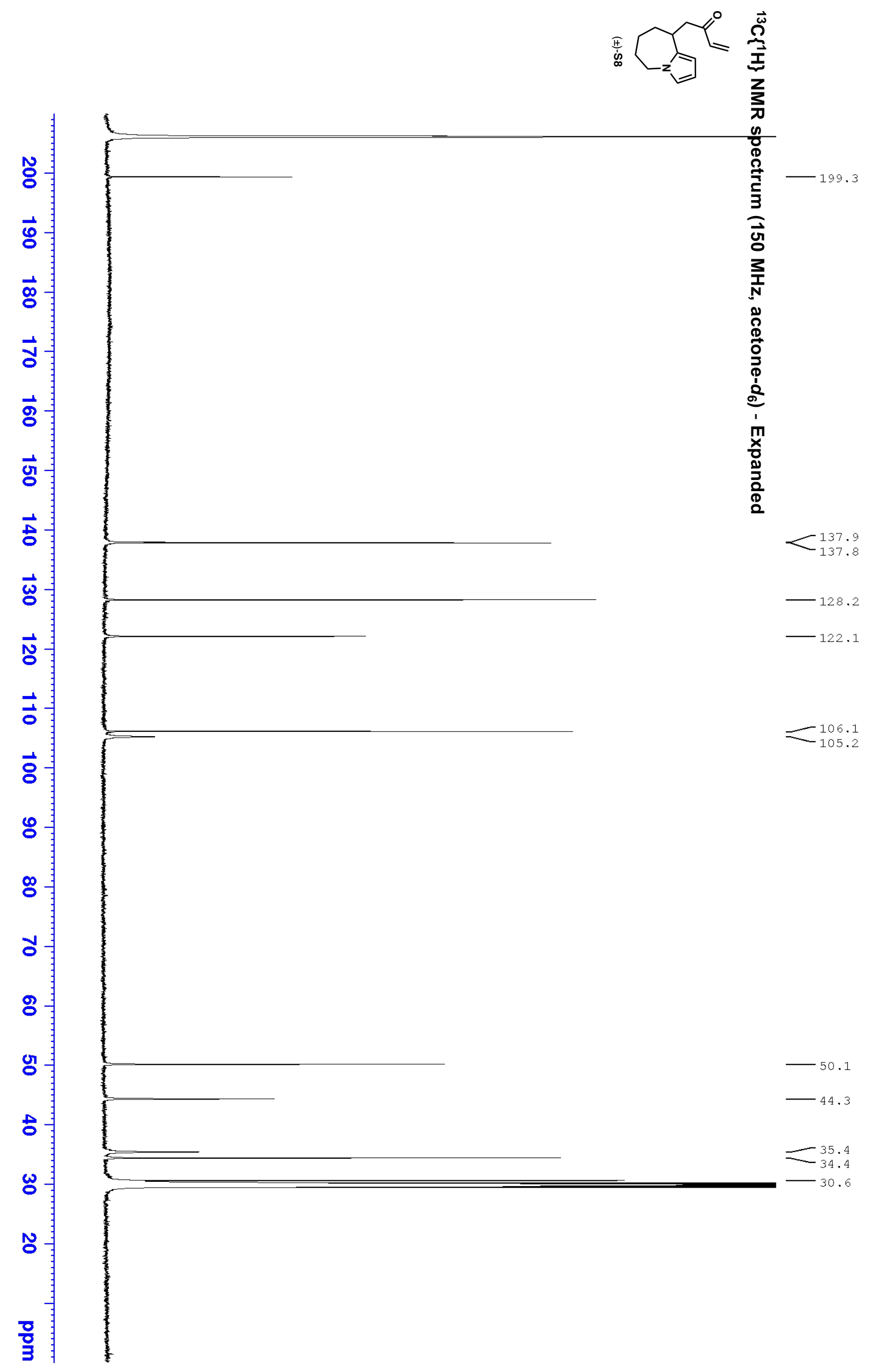




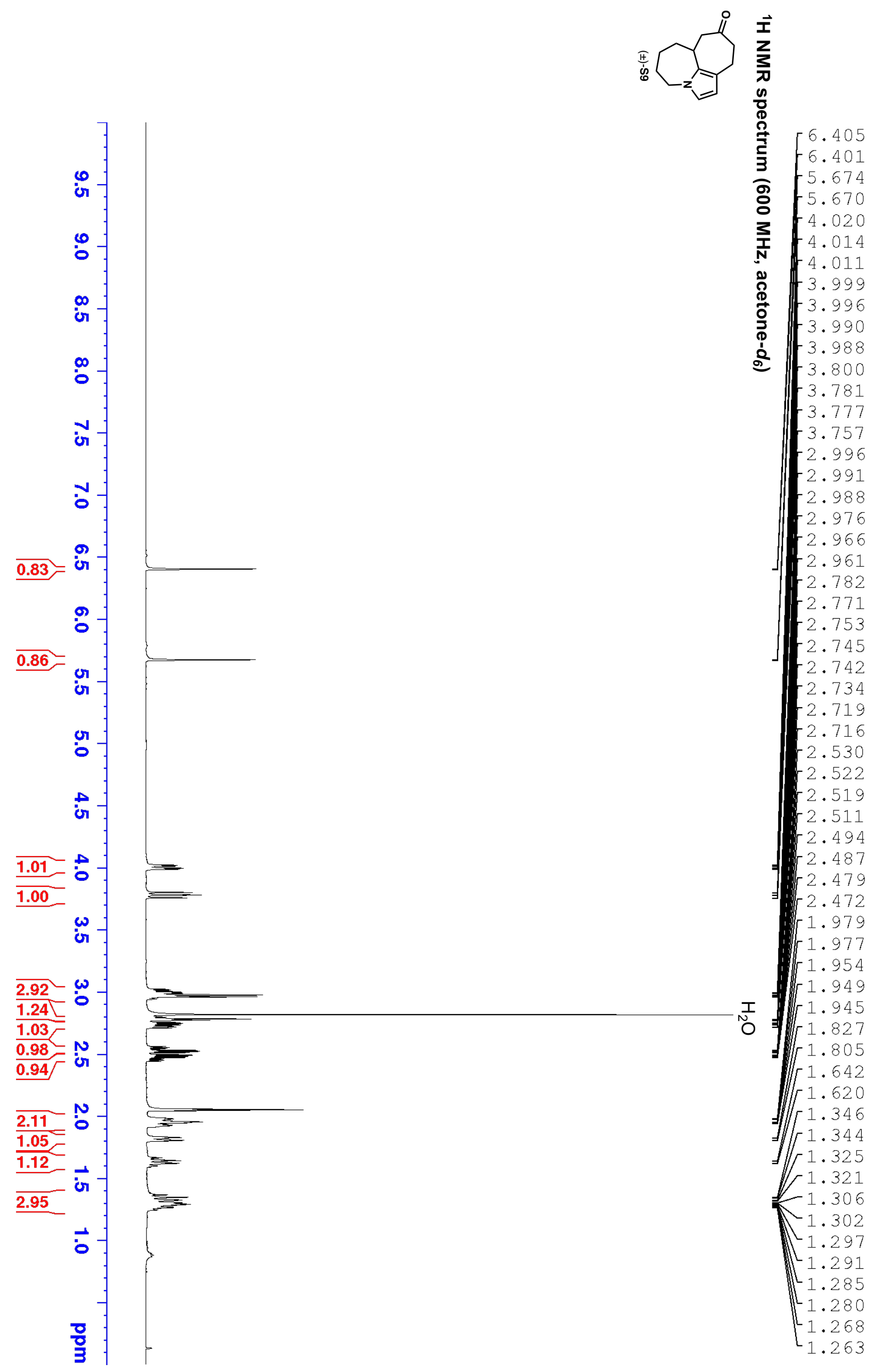




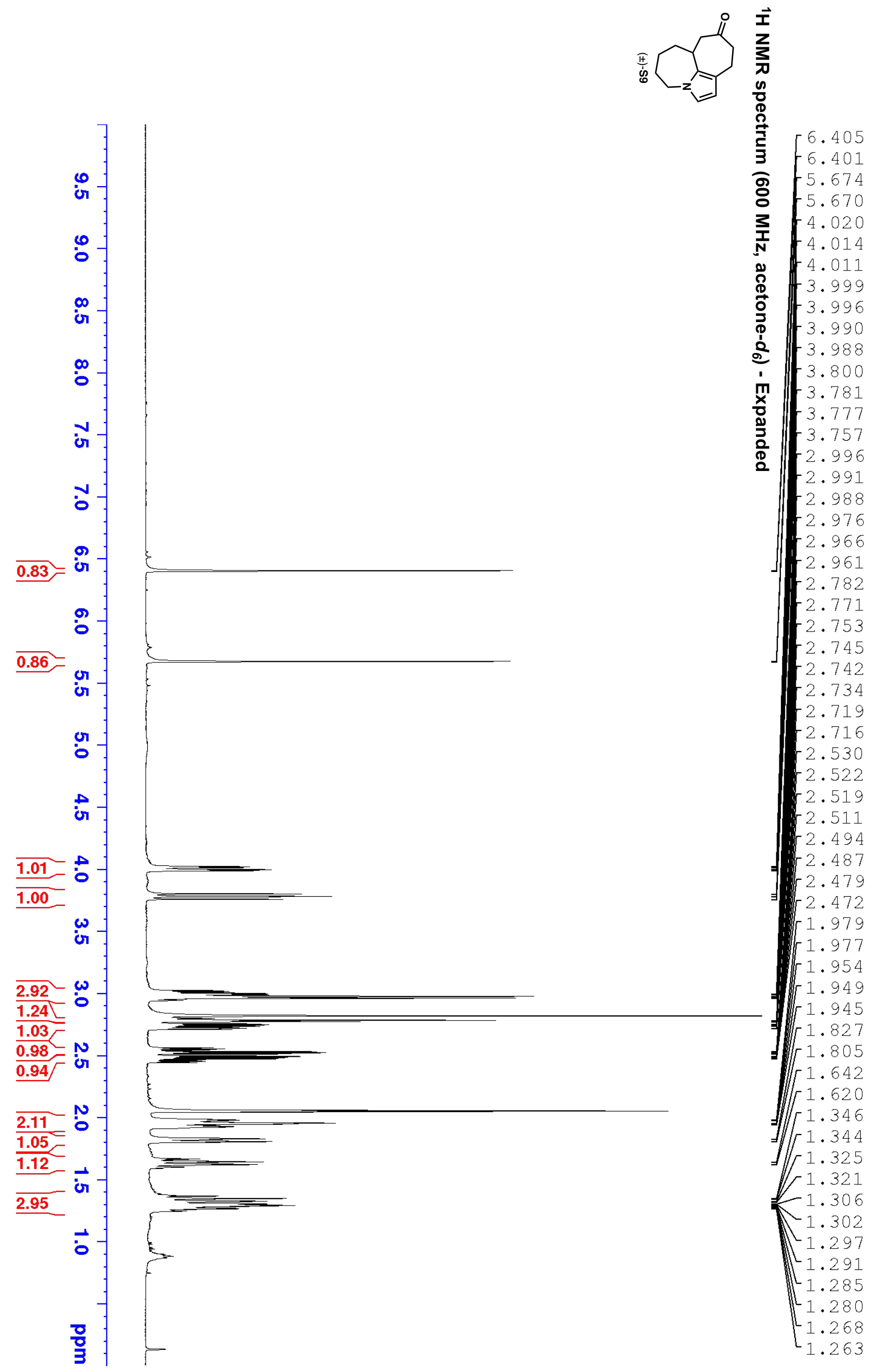




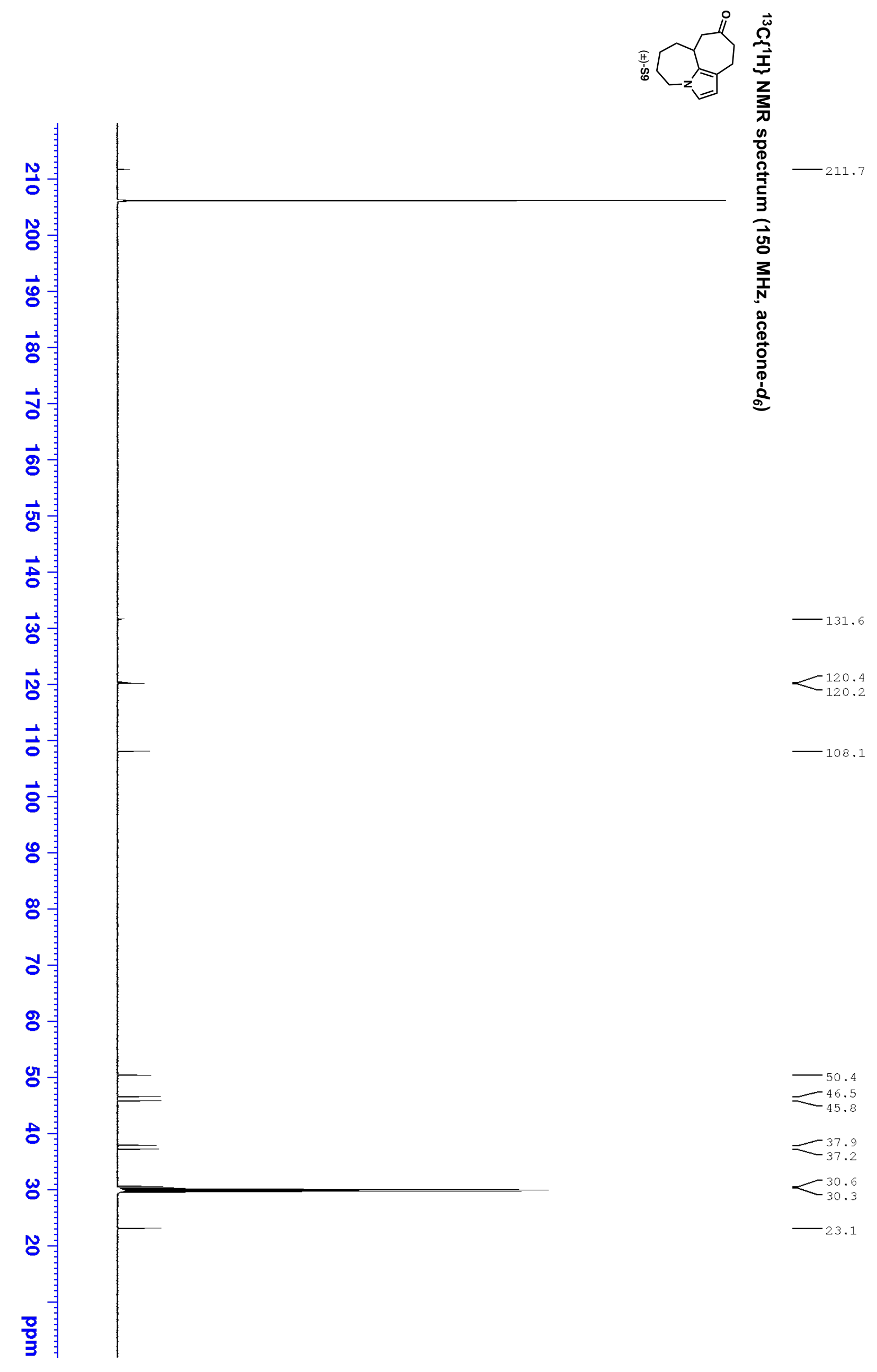




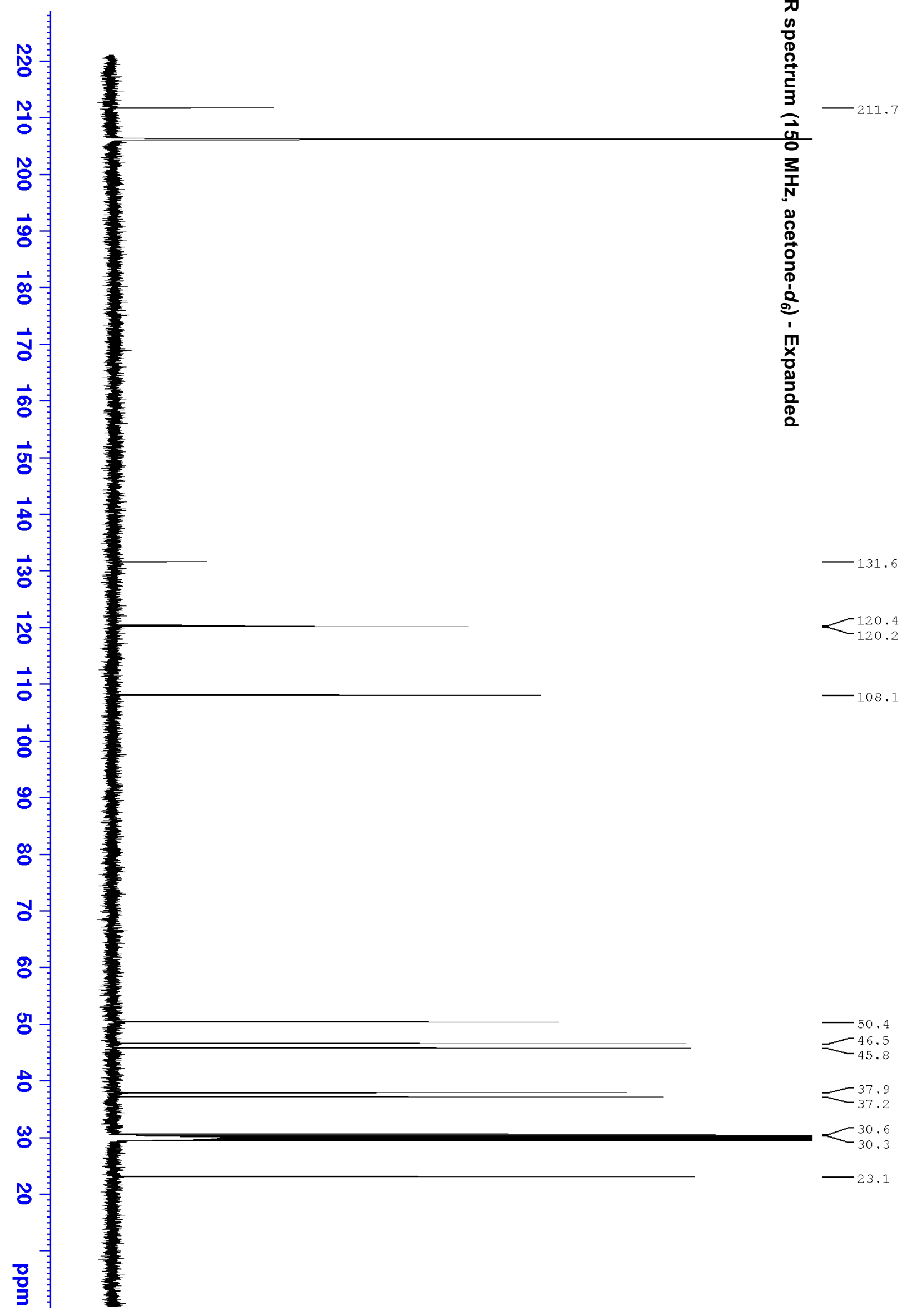




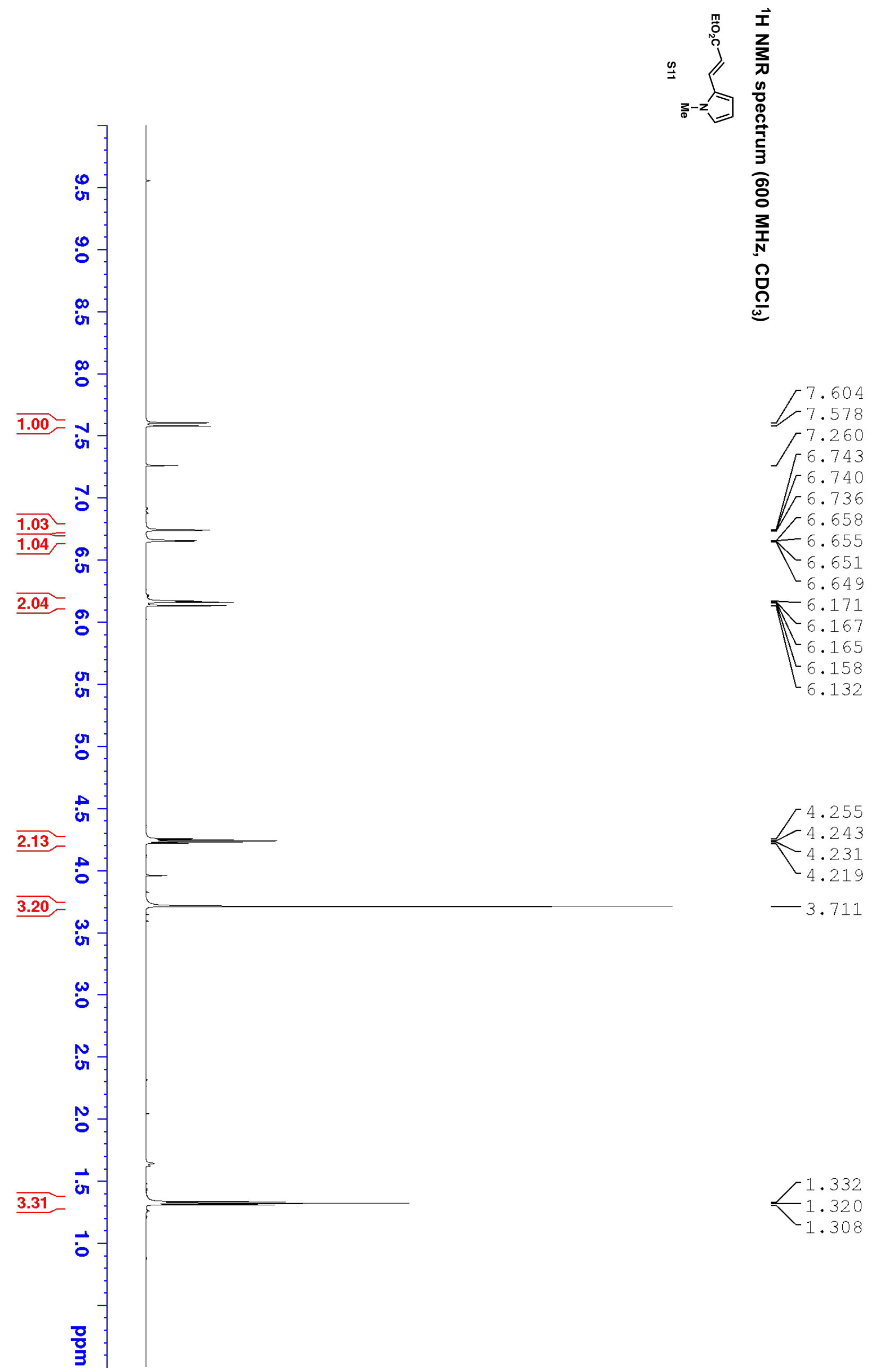



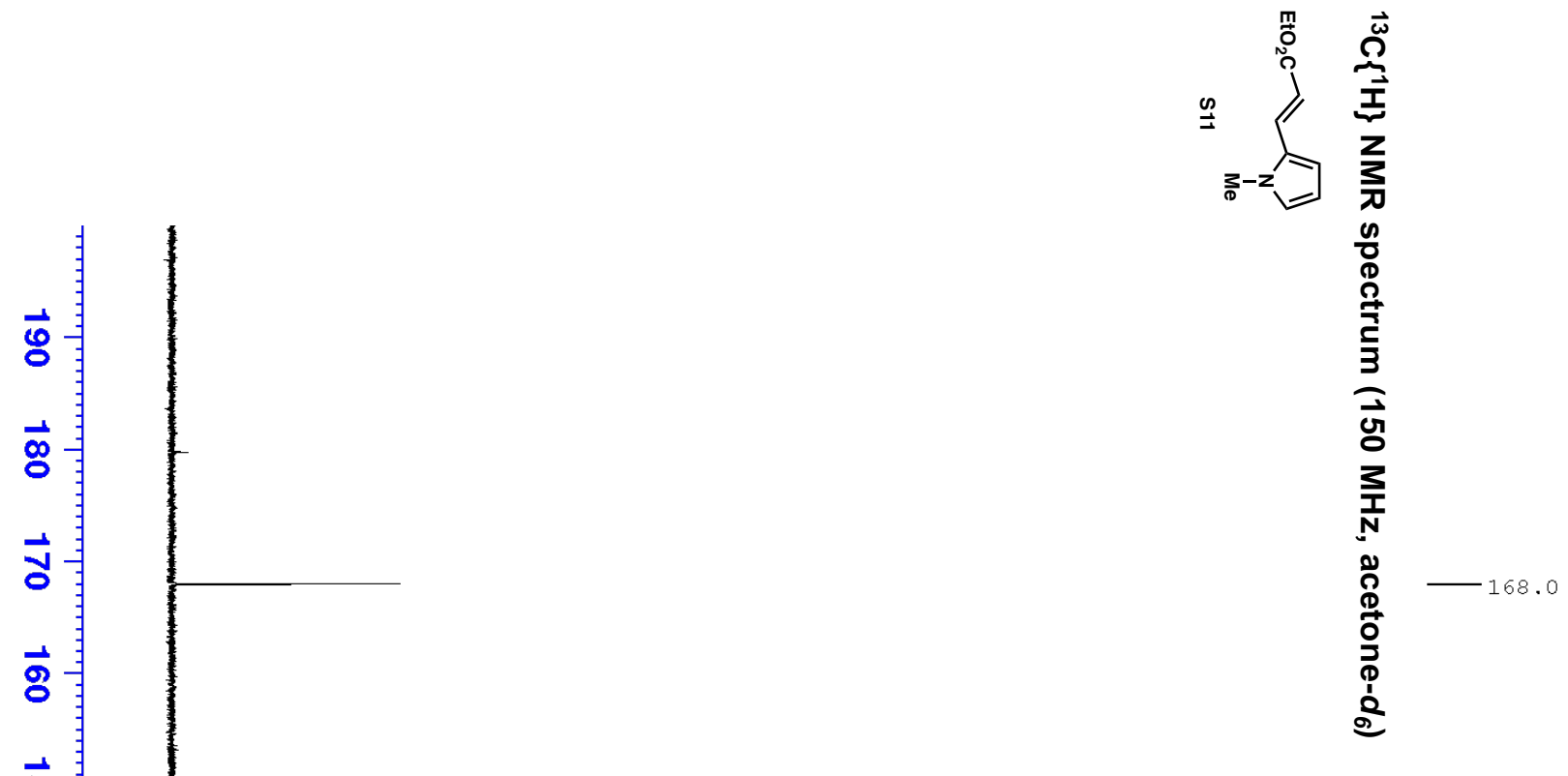

잉

항

$\vec{\omega}$

$\vec{N}$

$\overrightarrow{0}$

홍

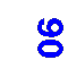

$\infty$

ป

8

or

ㅇ

$\omega$

ง

응 


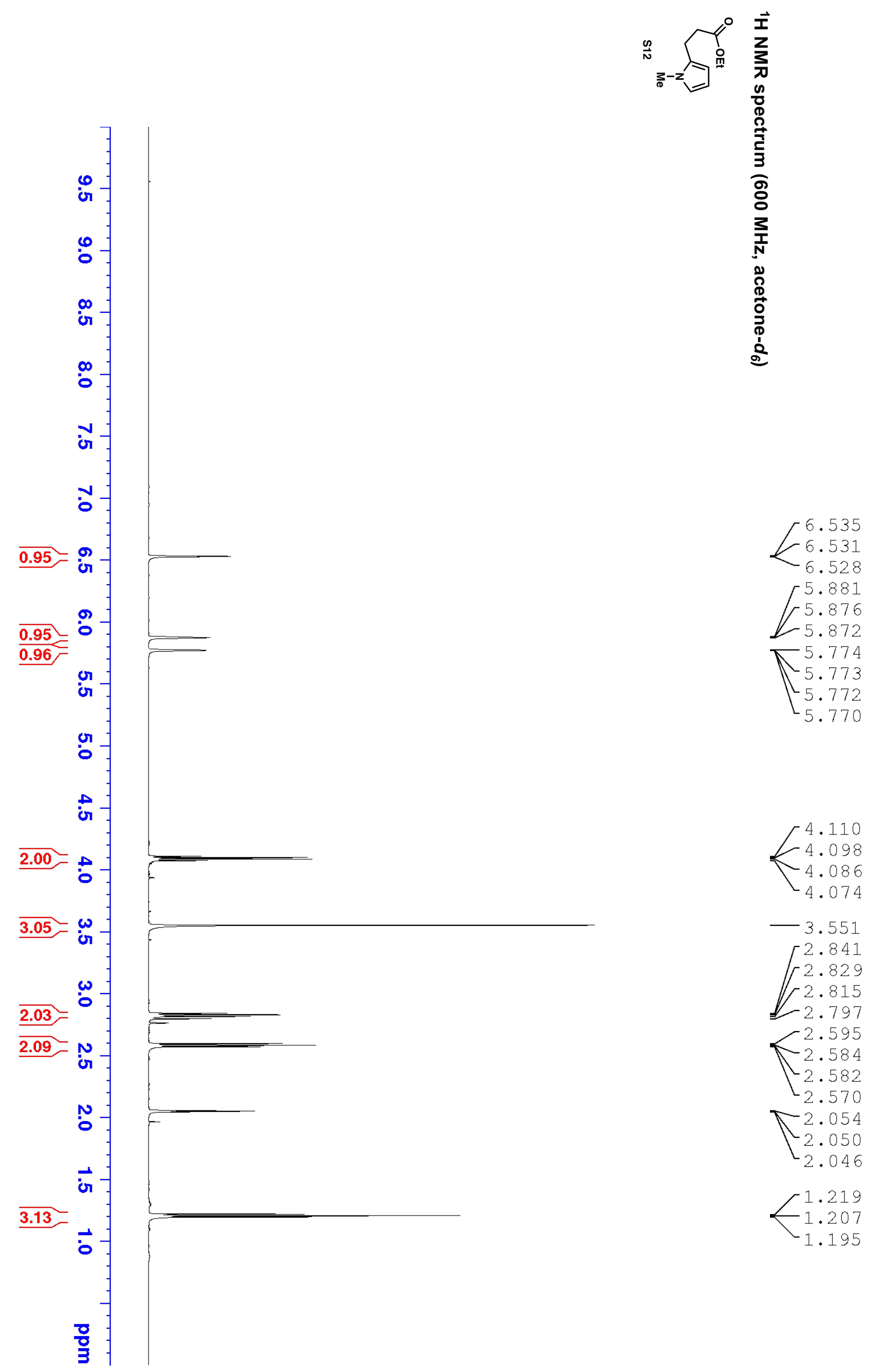




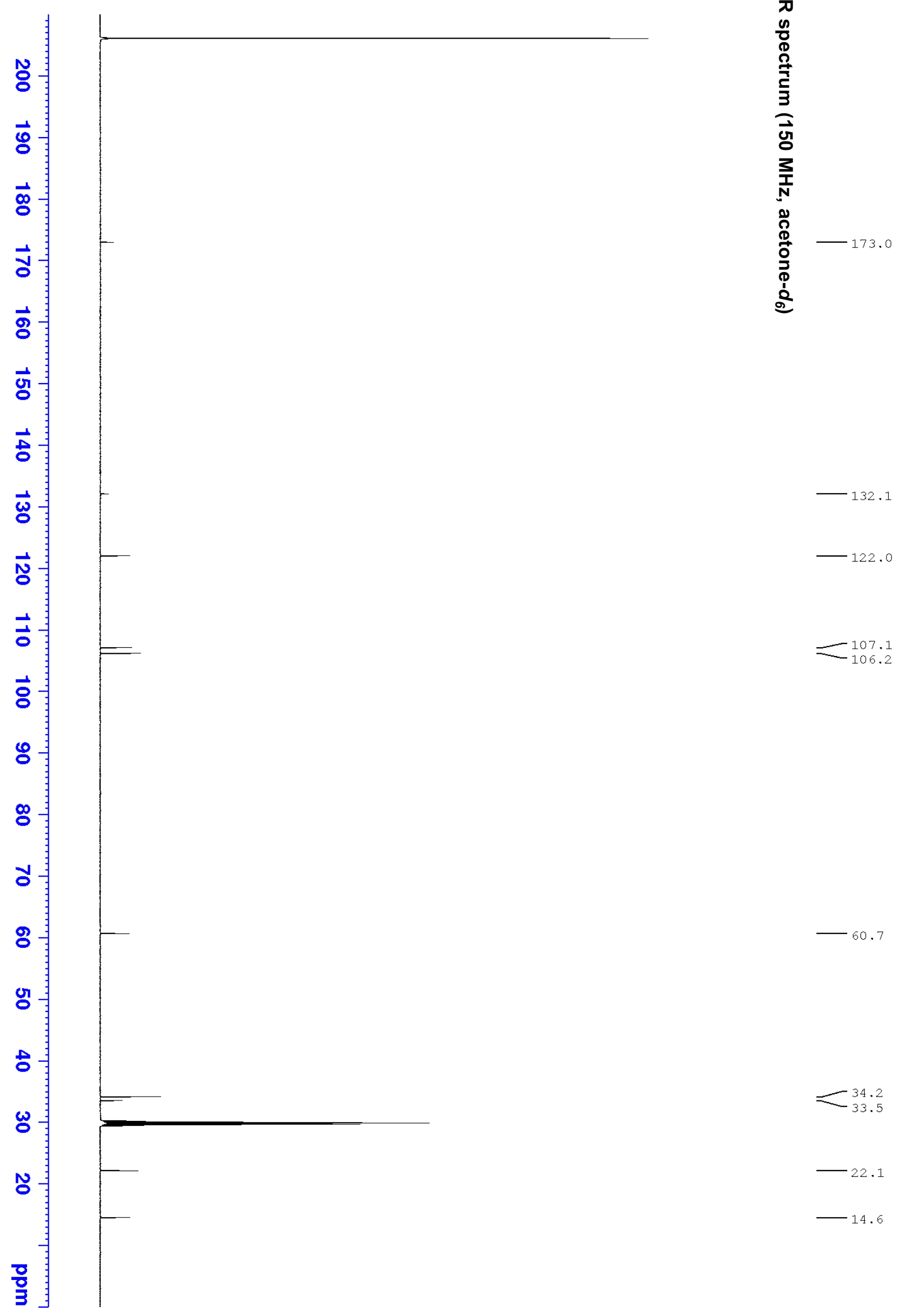




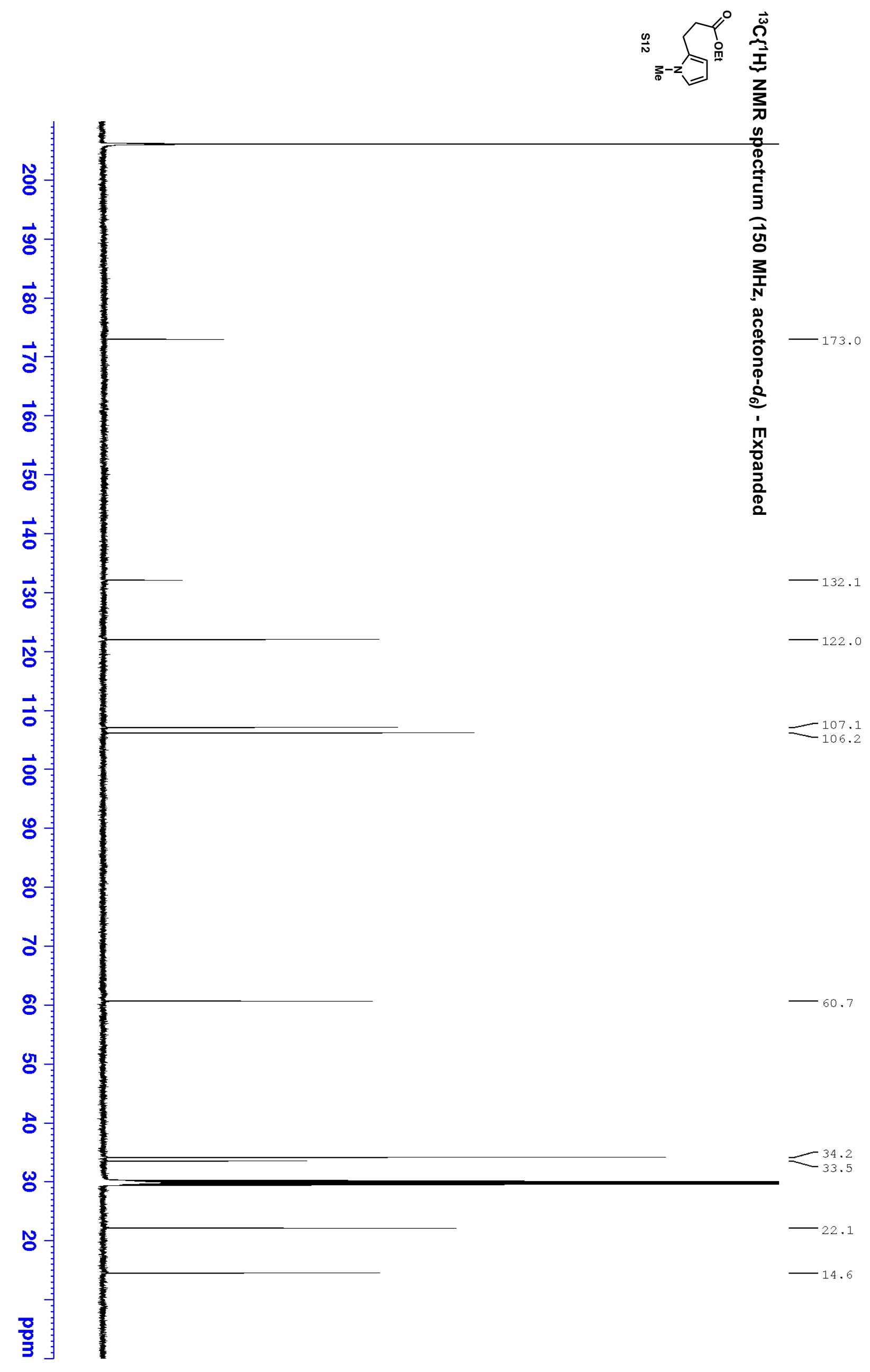



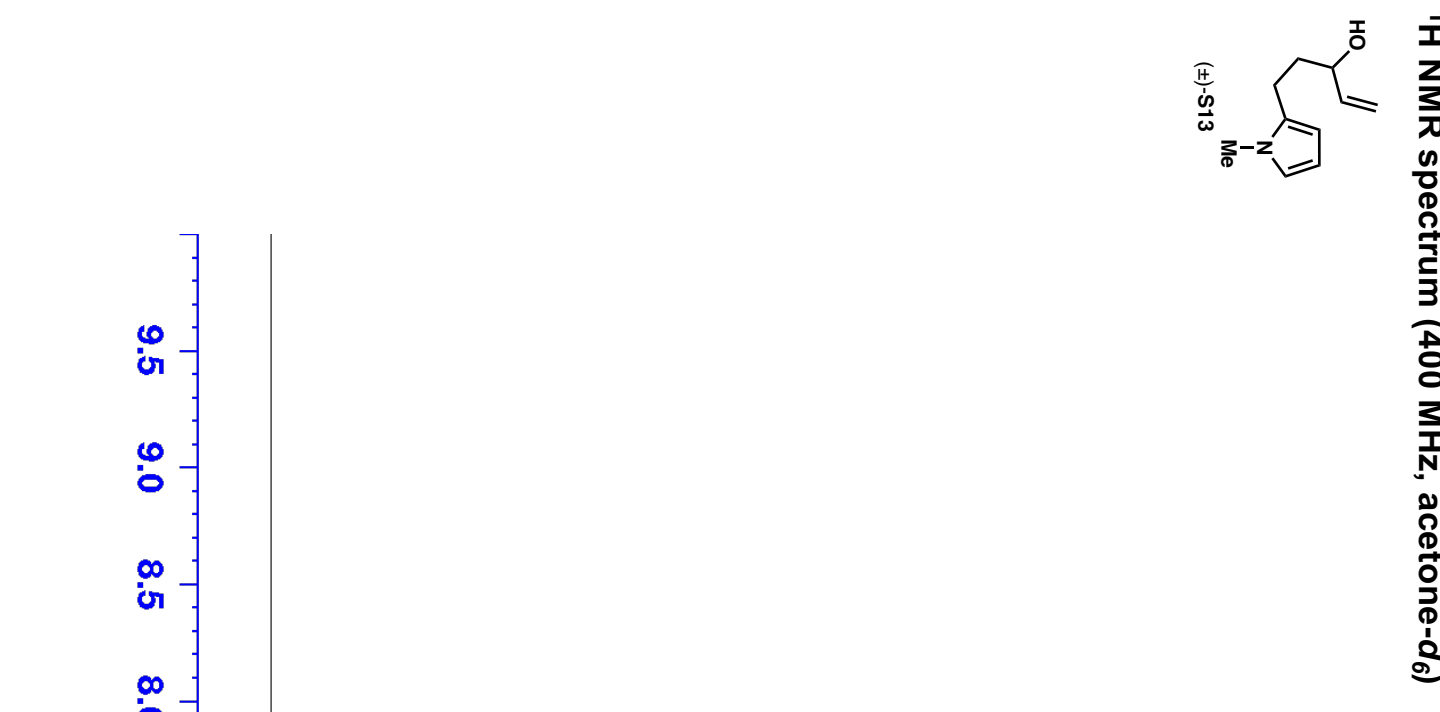

$-6.509$

6.503

5.947

5.935

5.921

5.918

5.904

5.892

5.882

$-5.877$

5.874

5.866

5.768

5.765

5.763

5.761

5.759

$\underline{0.96}$

5.755

5.249

5.245

5.241

J. 5.206

5.202

55.198

5.043

$\overline{\frac{1.00}{1.01}}$

or

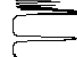

$-5.039$

$-5.035$

$-5.017$

5.013

5.009

4.130

3.812

3.800

3.526

2.671

r2.655

52.649

- 2.634

$\digamma^{2.617}$

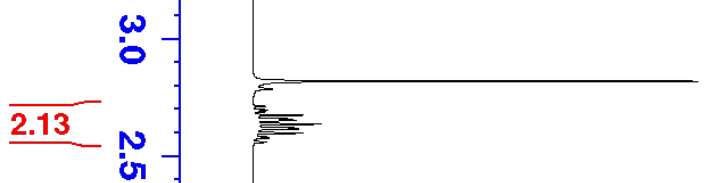

2.613

2.595

1.785

1.777

1.772

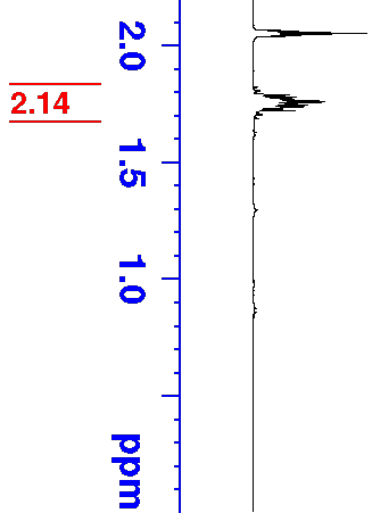

$-1.768$

1.763

1.759

1.754

1.749

1.745

1.743

1.737

1.736

$-1.732$ 


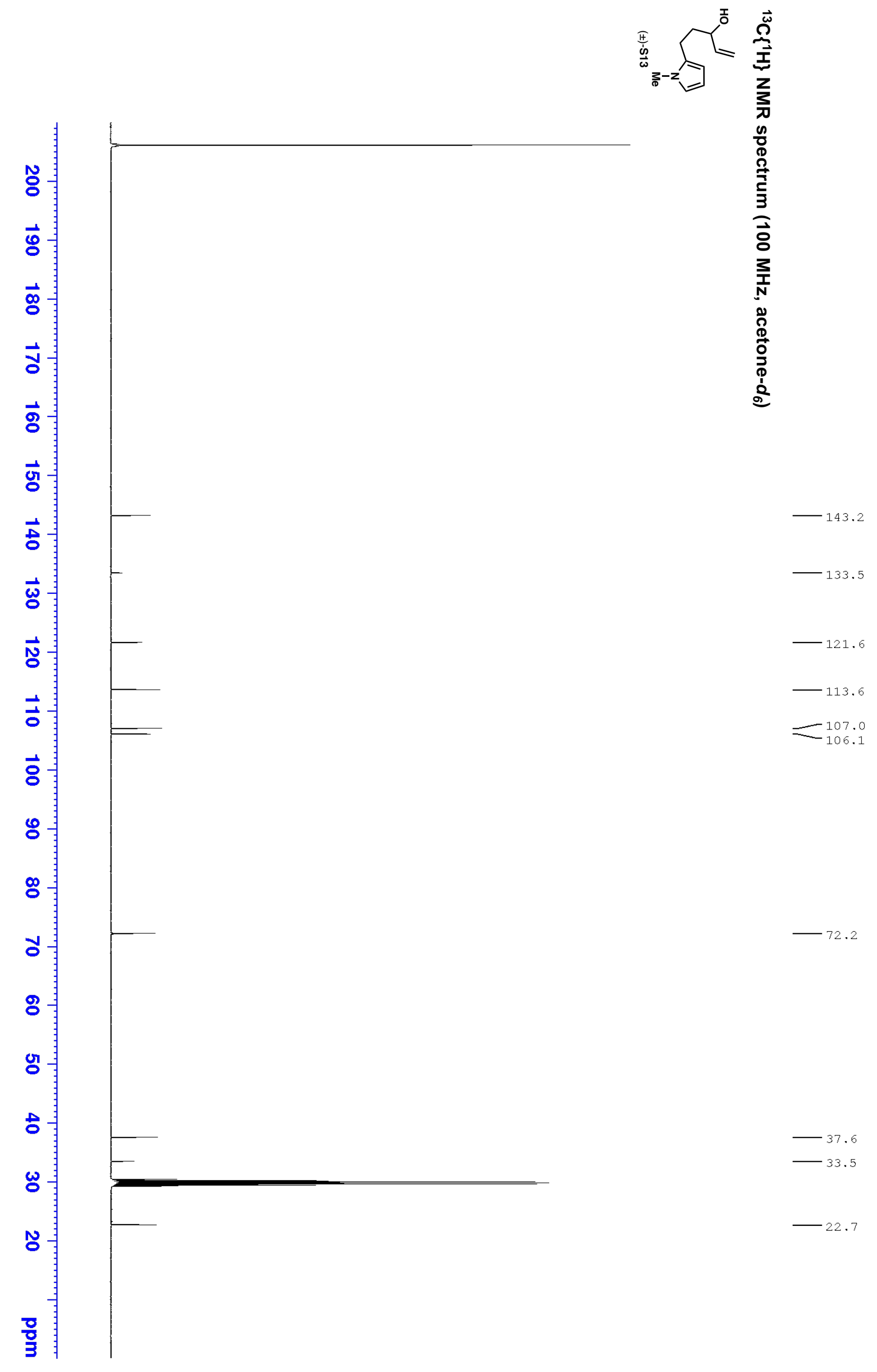




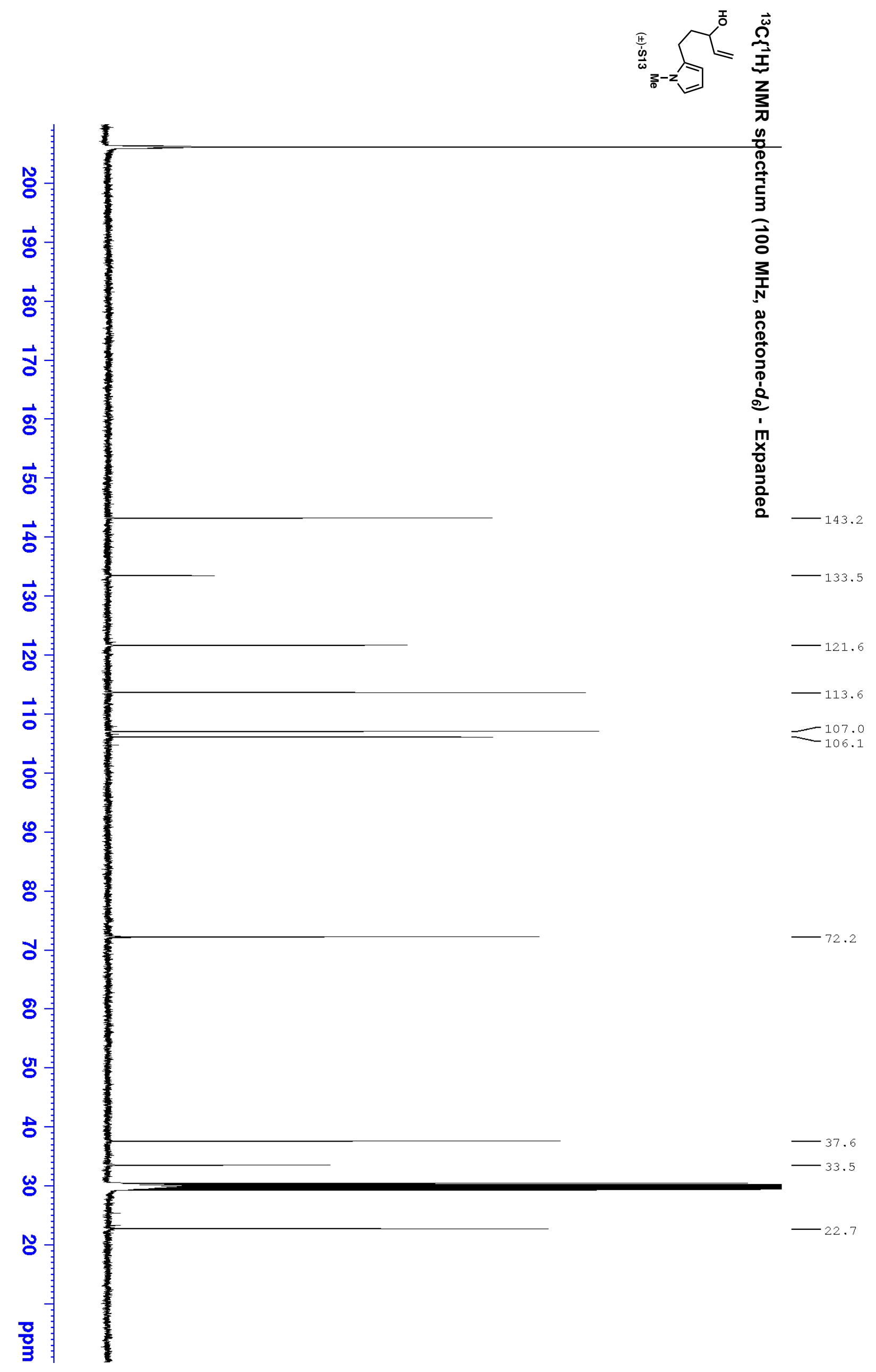




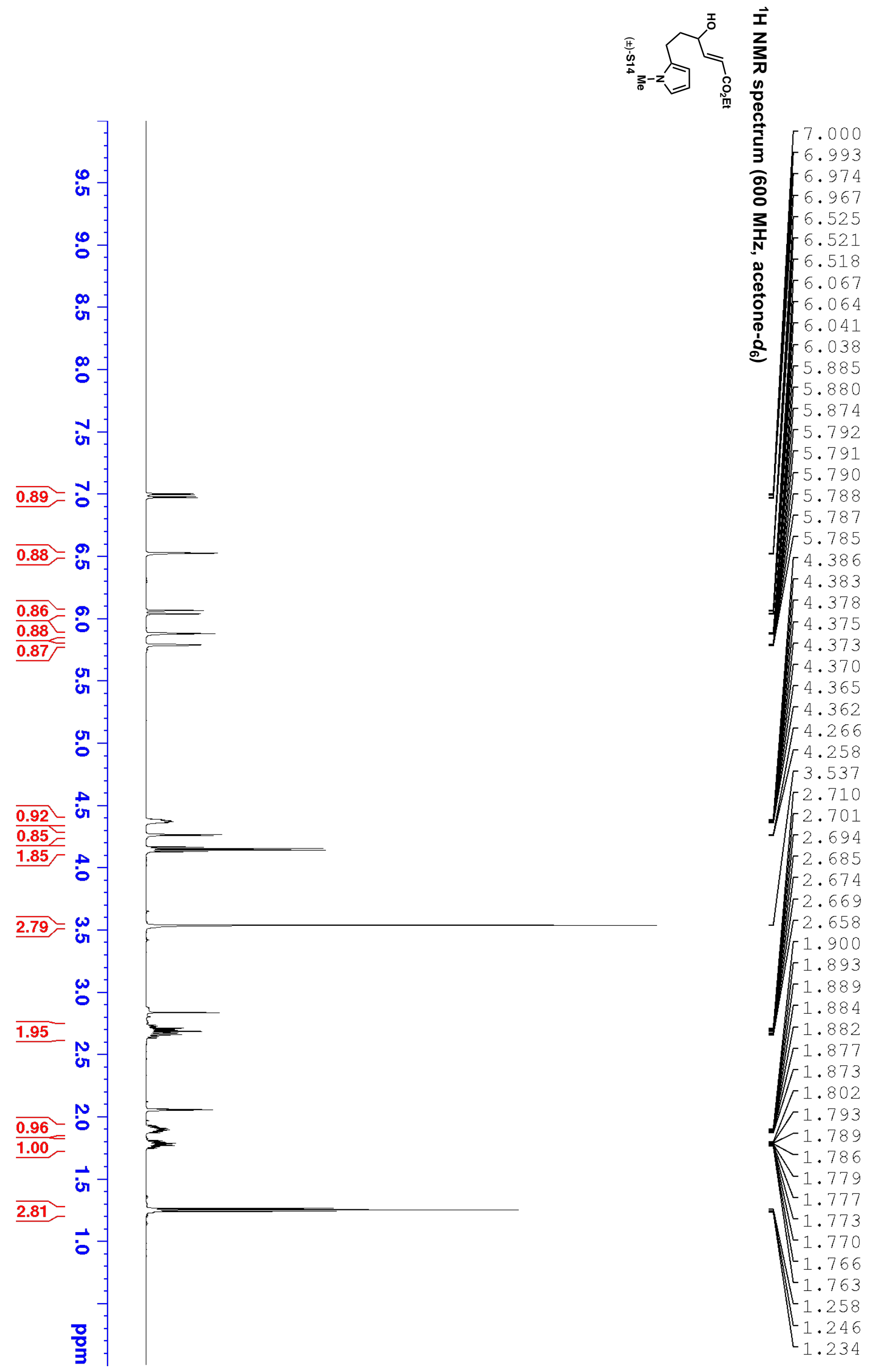




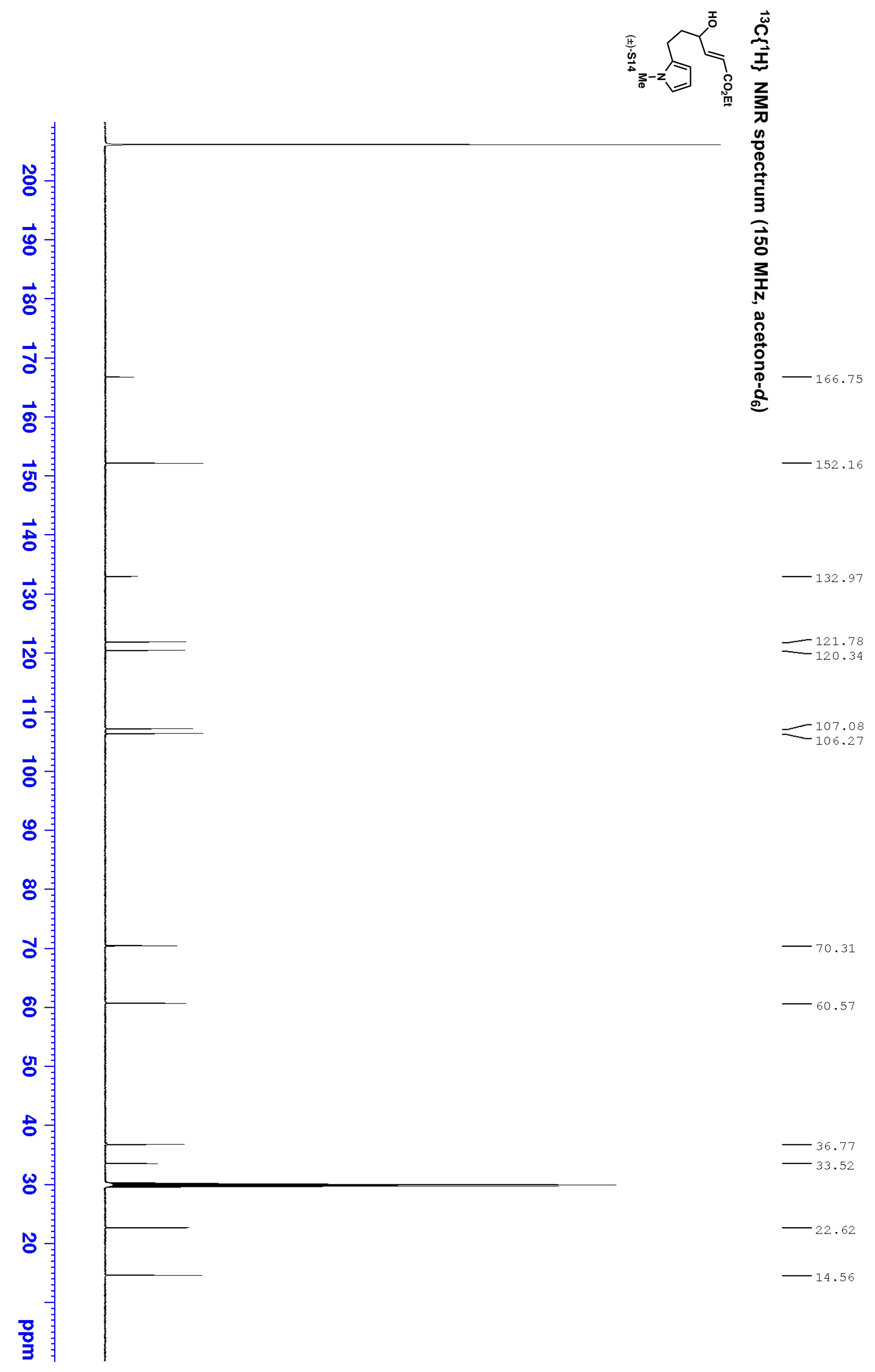




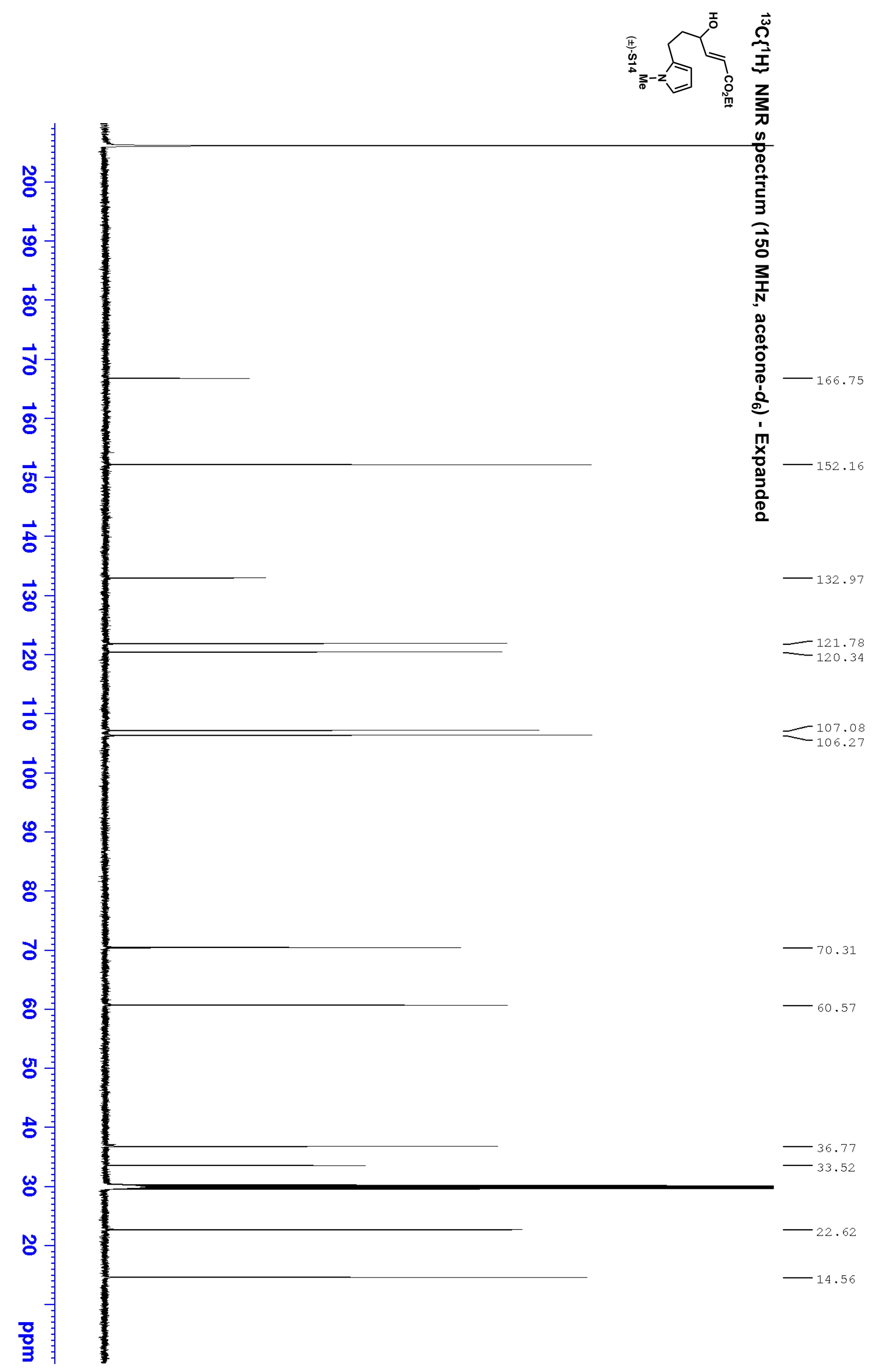




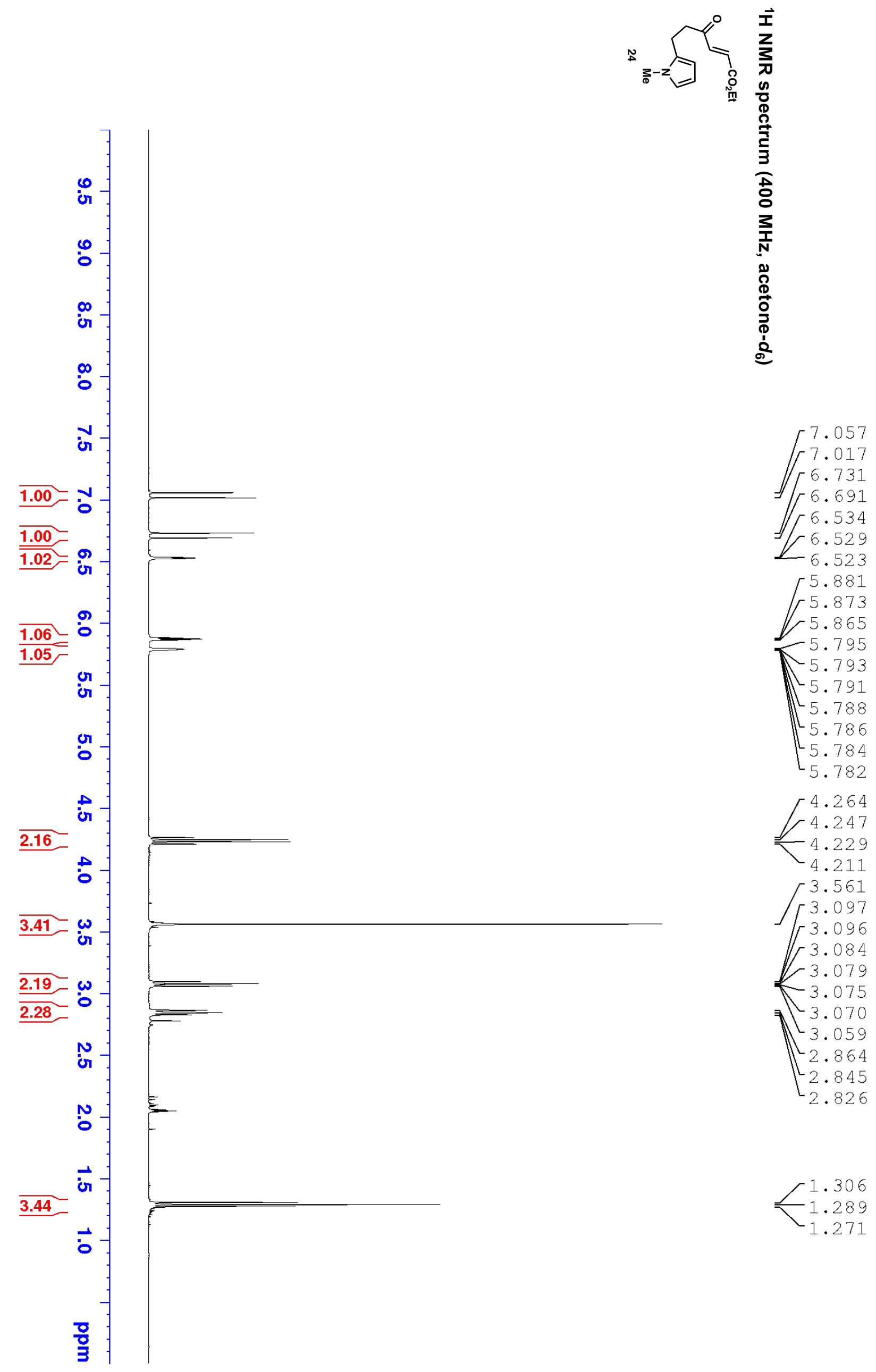




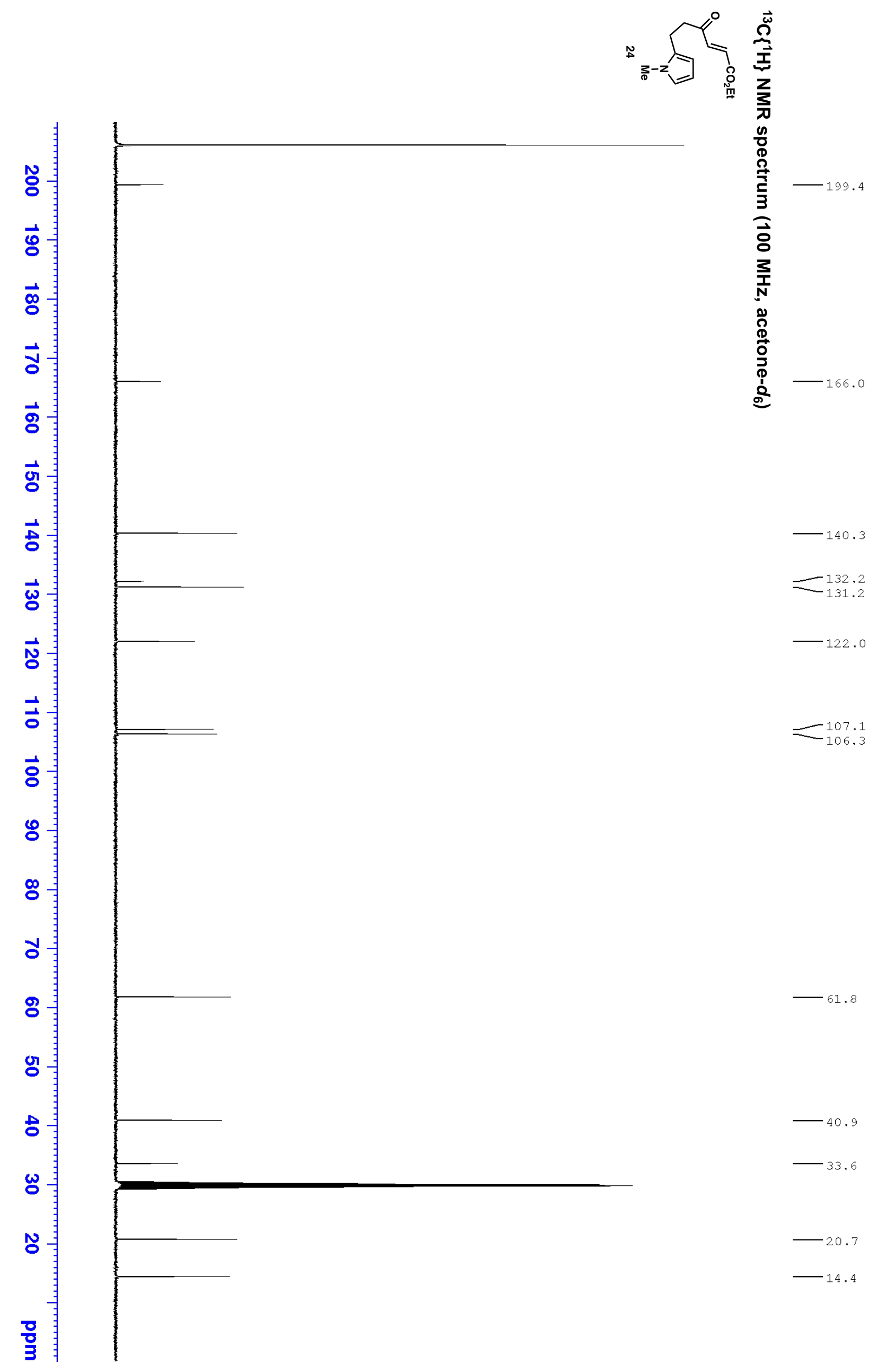




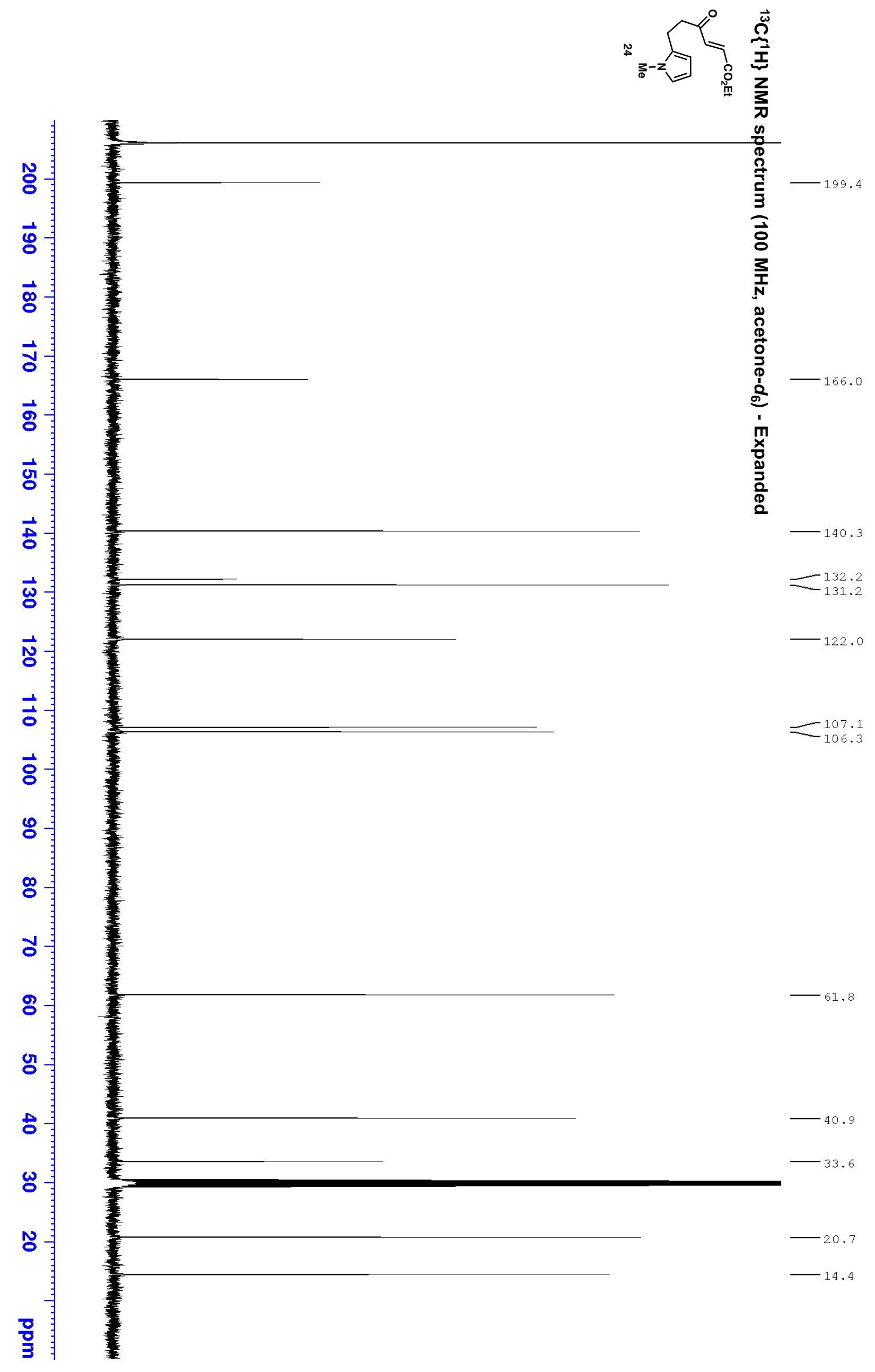




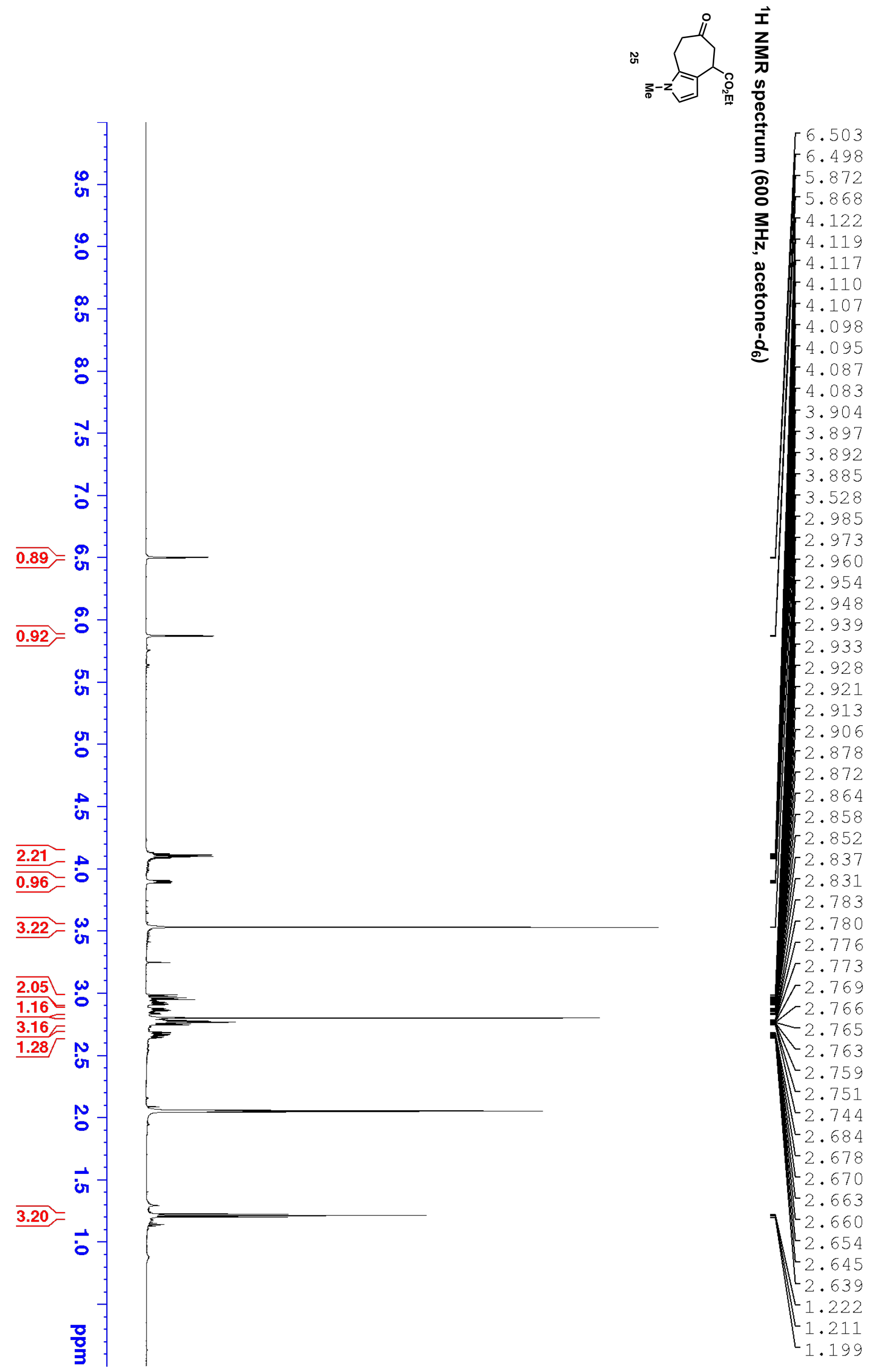




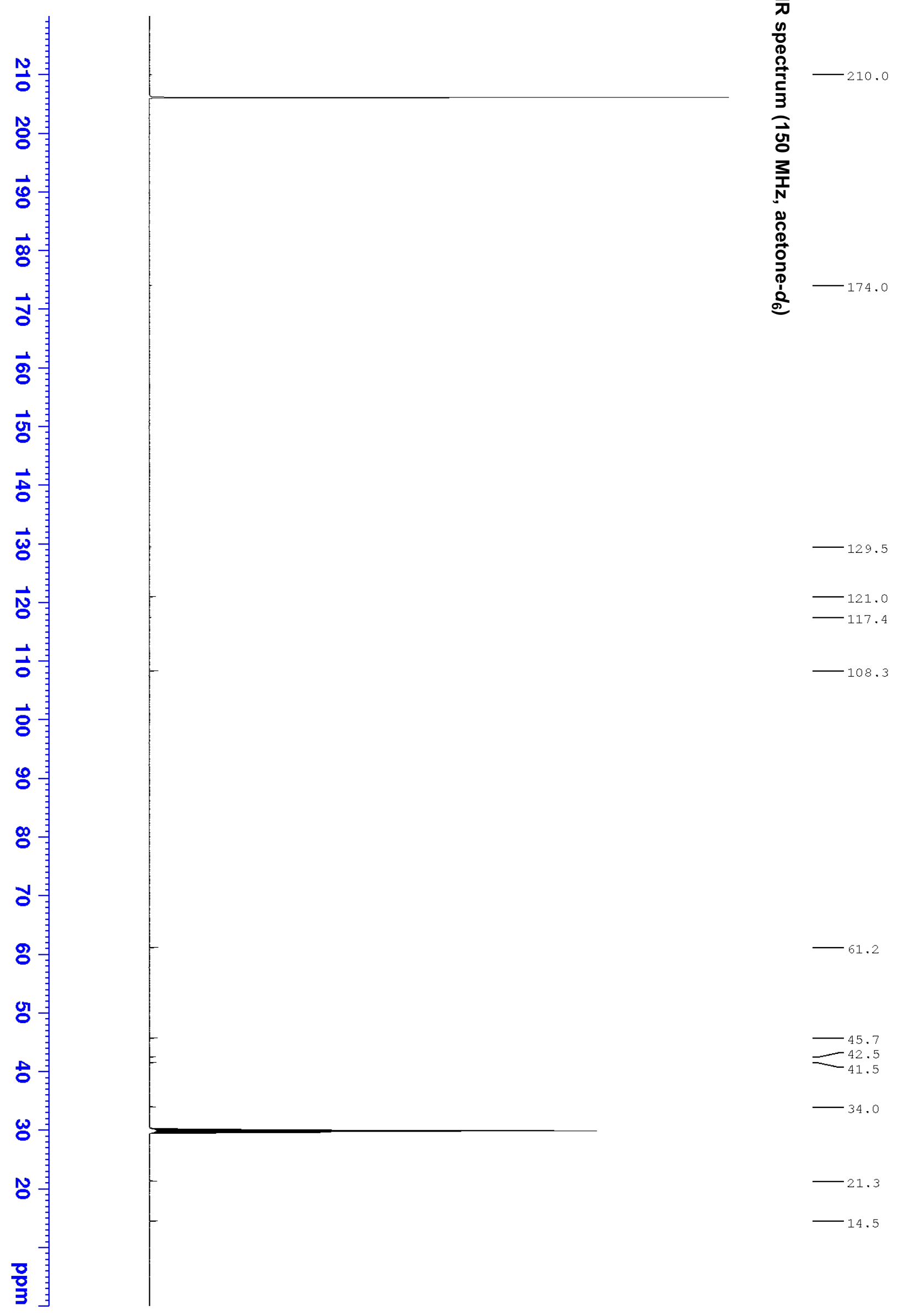




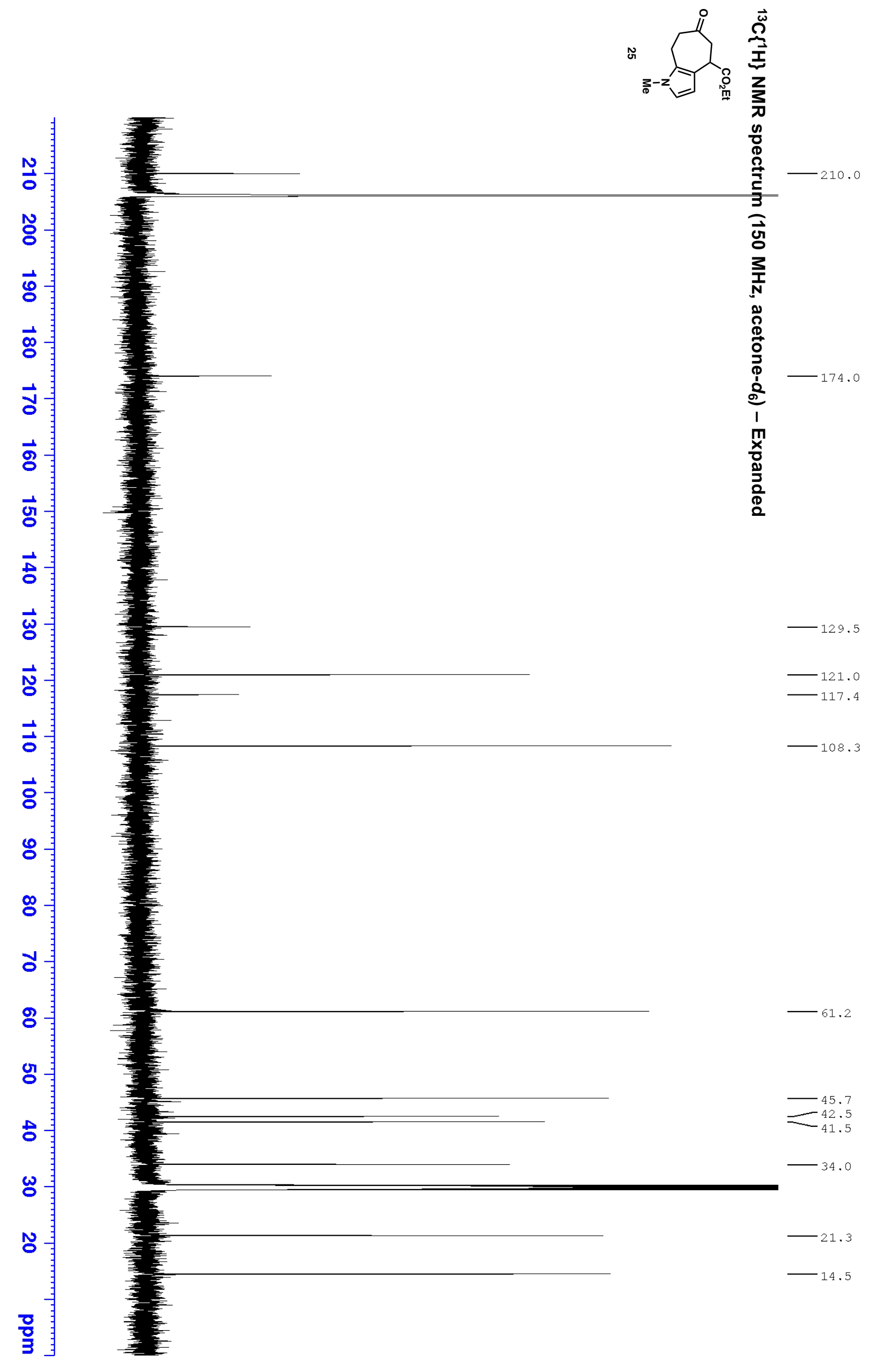




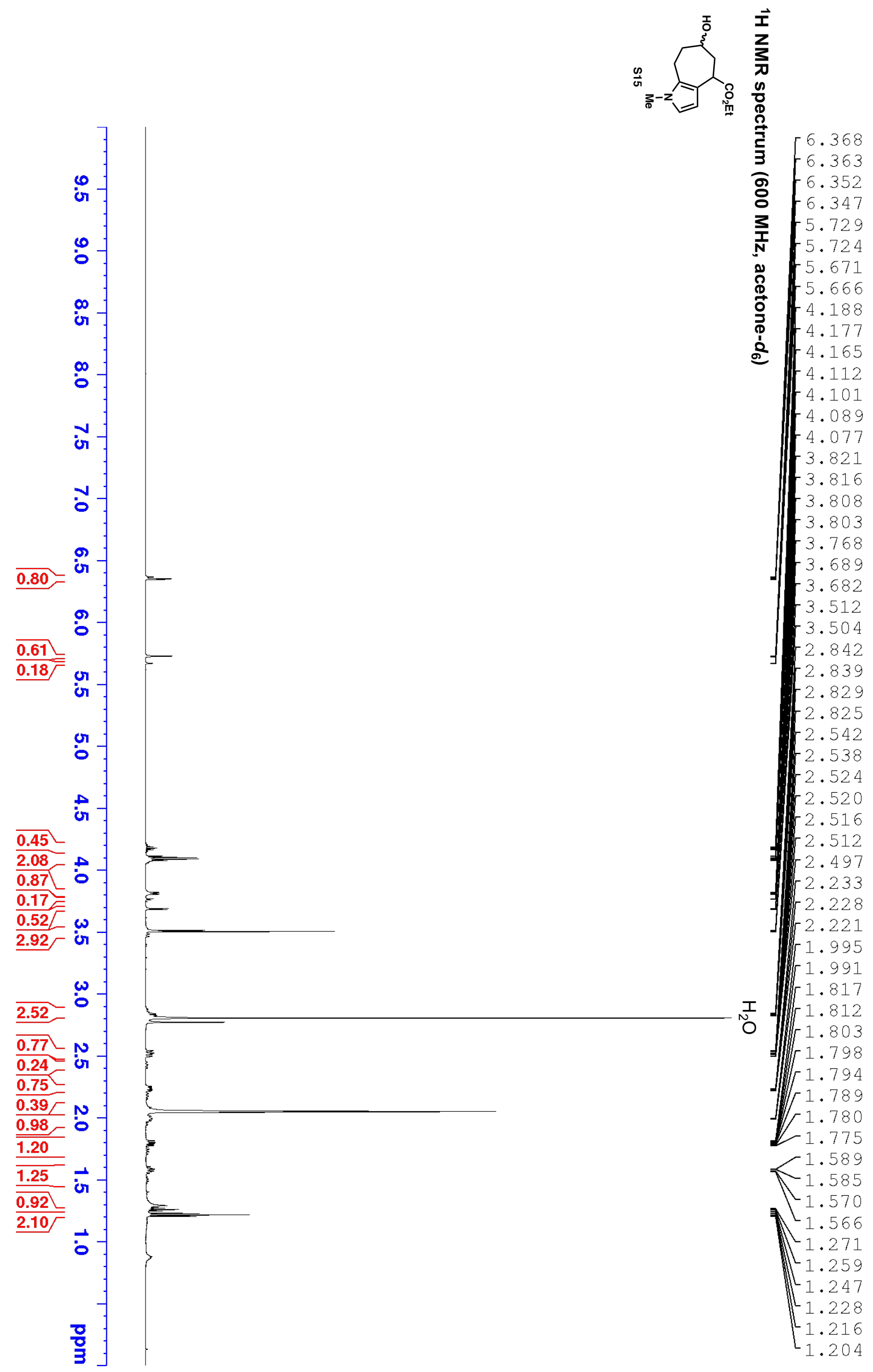




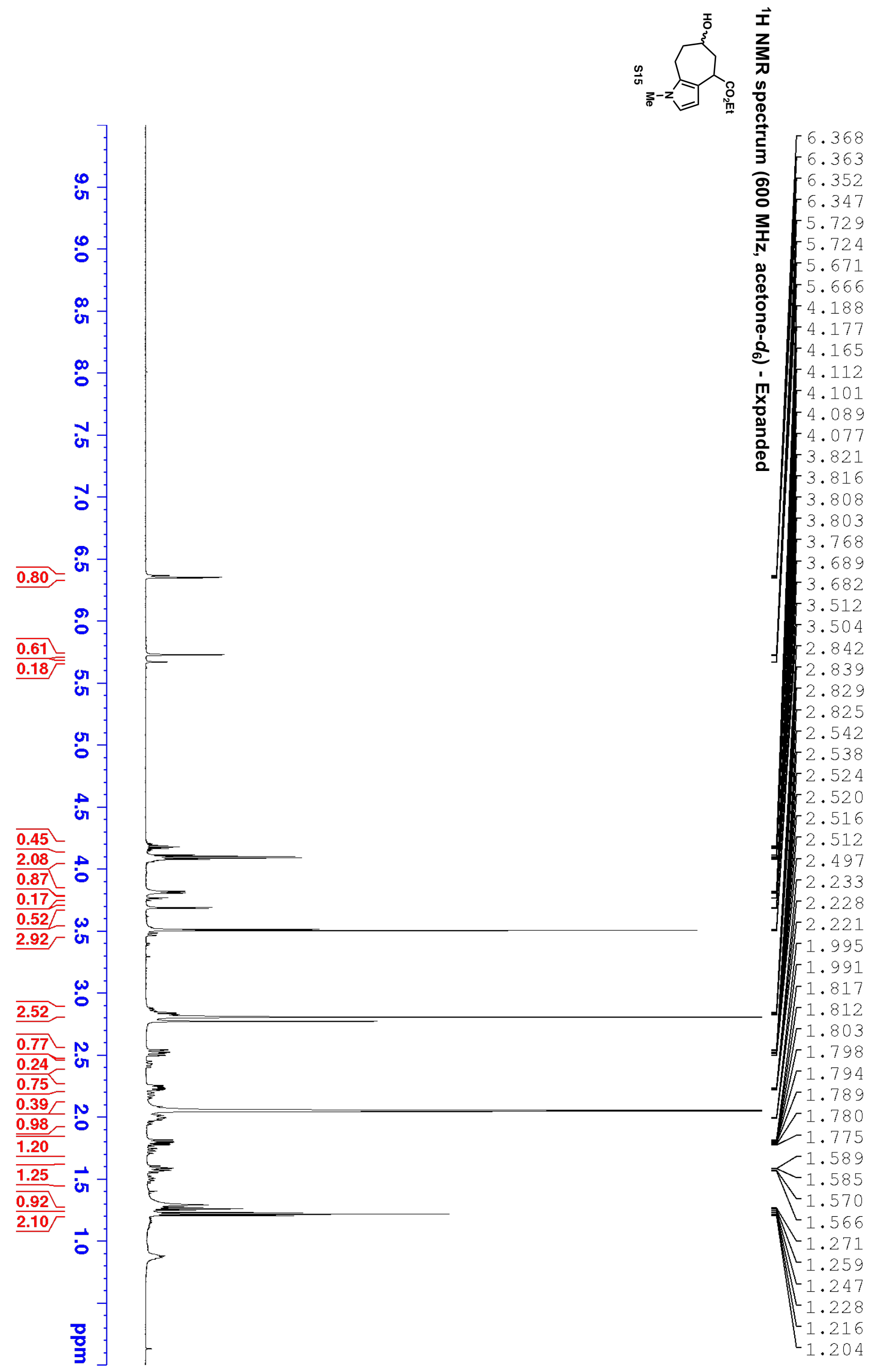




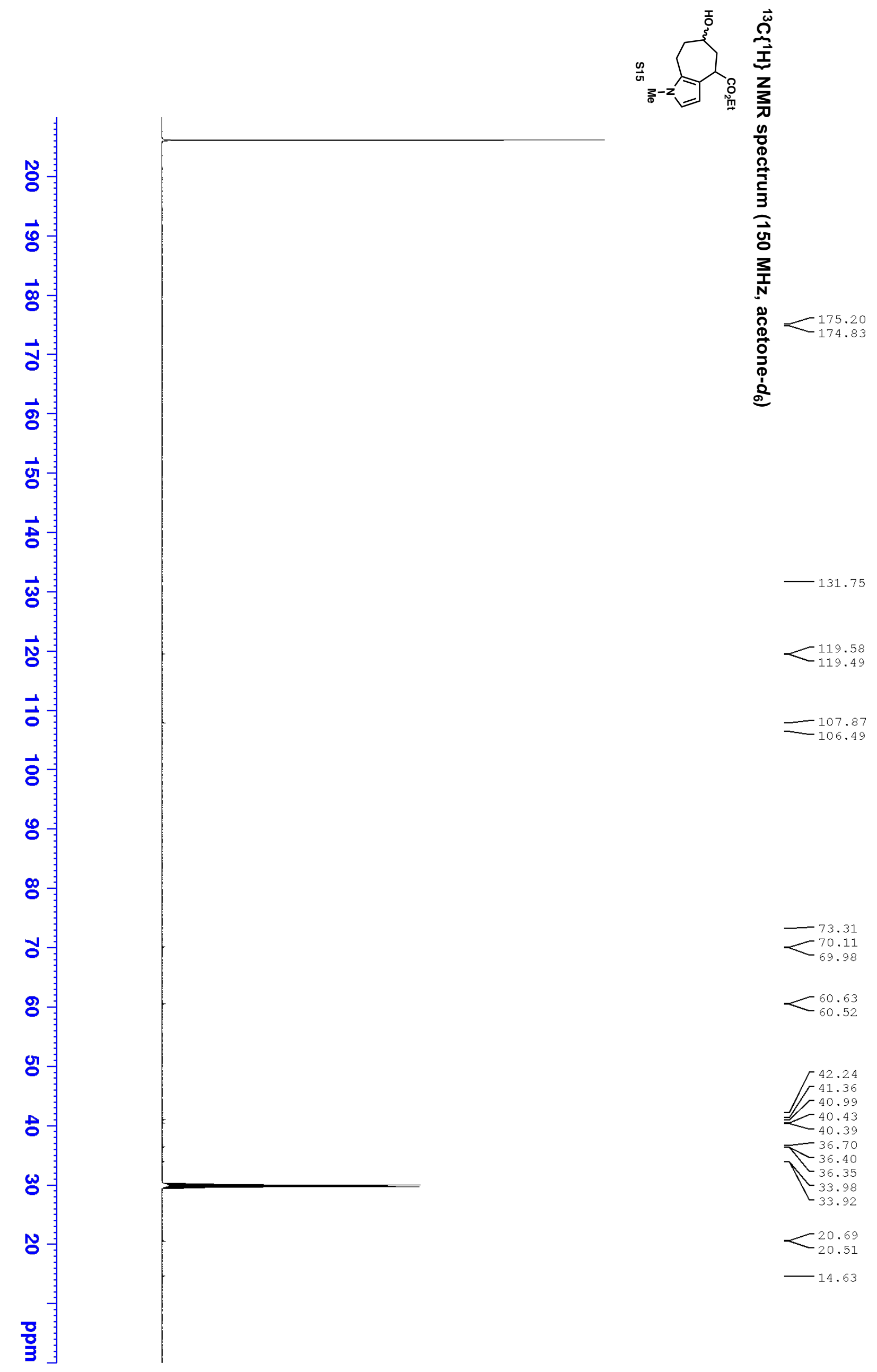




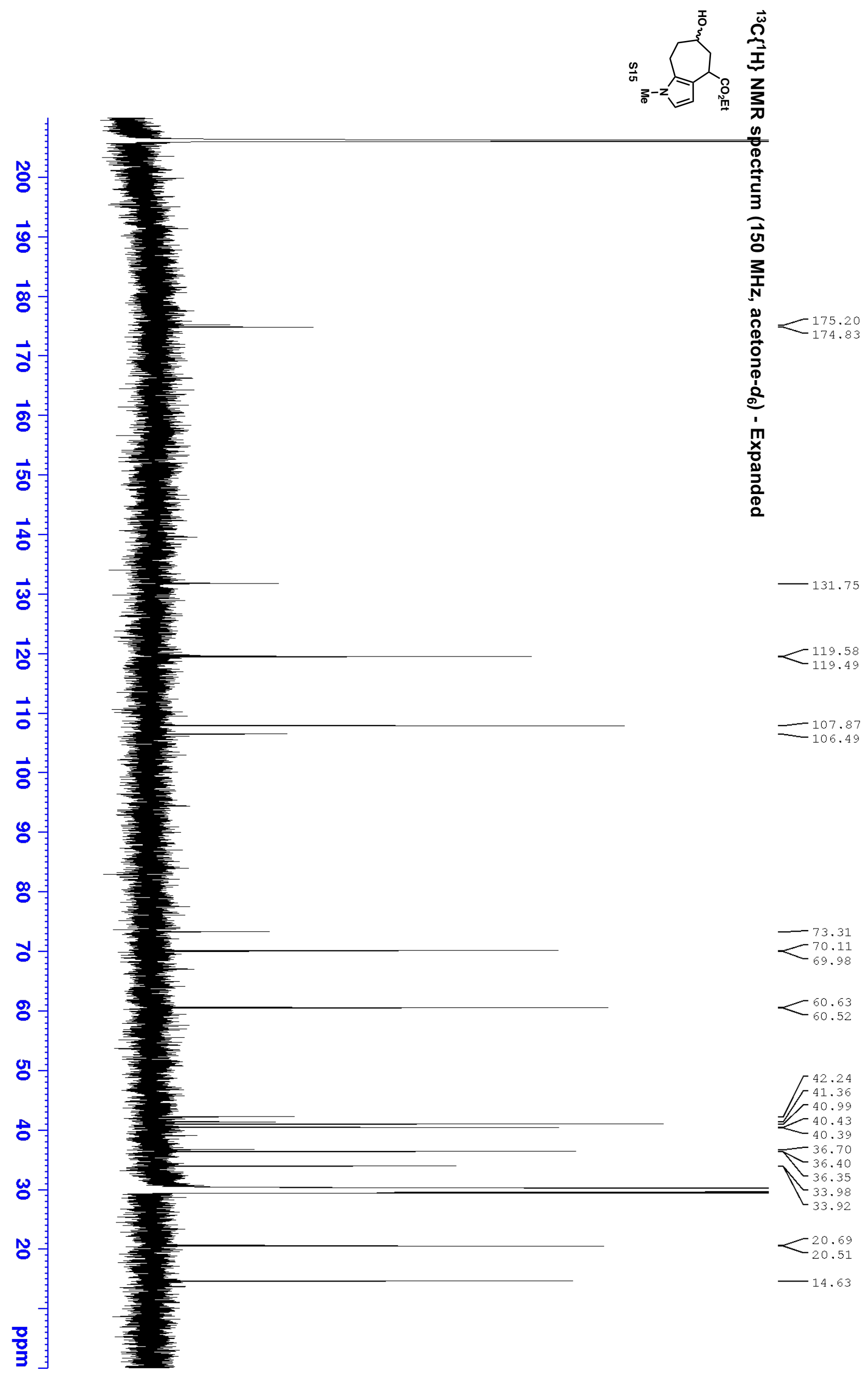




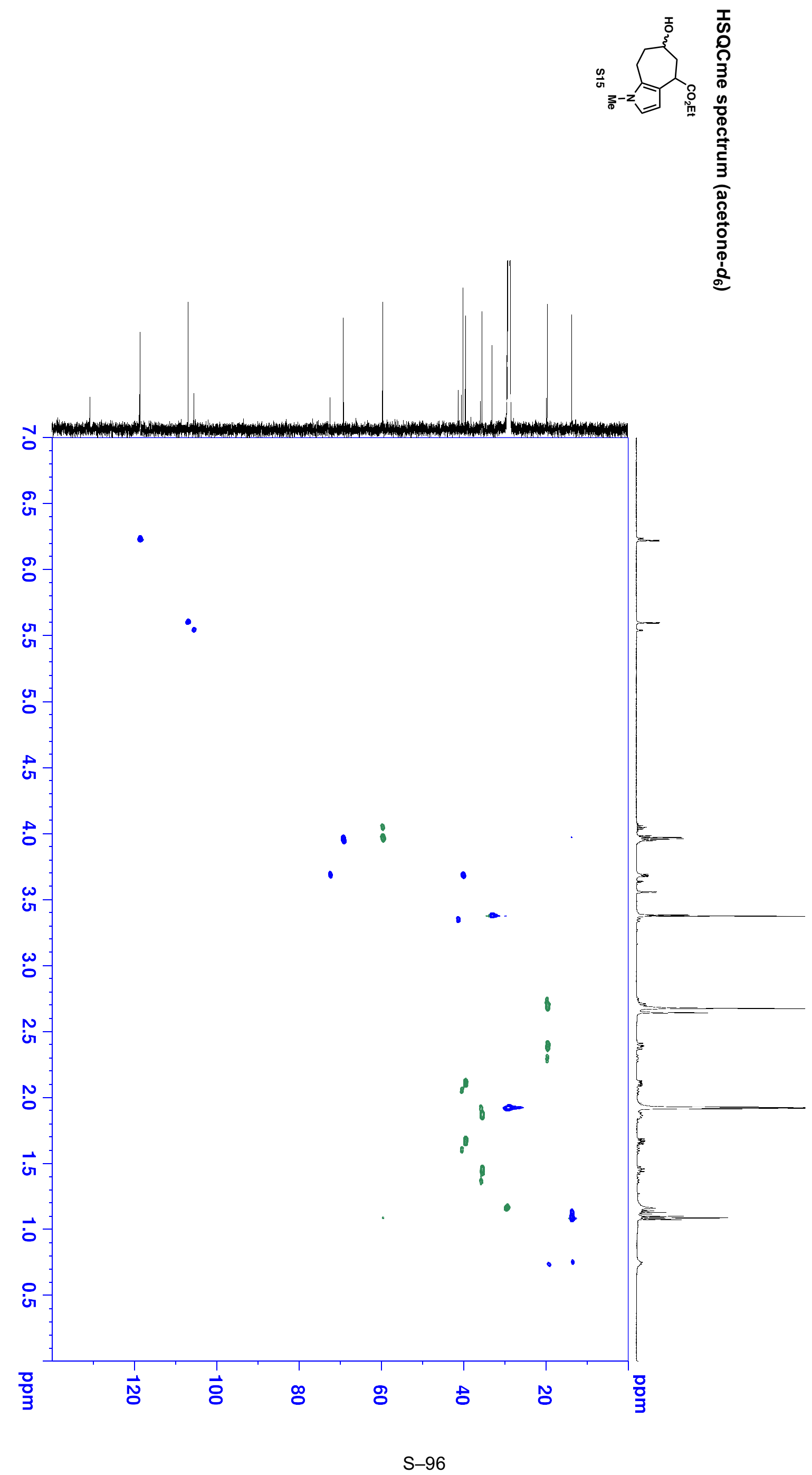




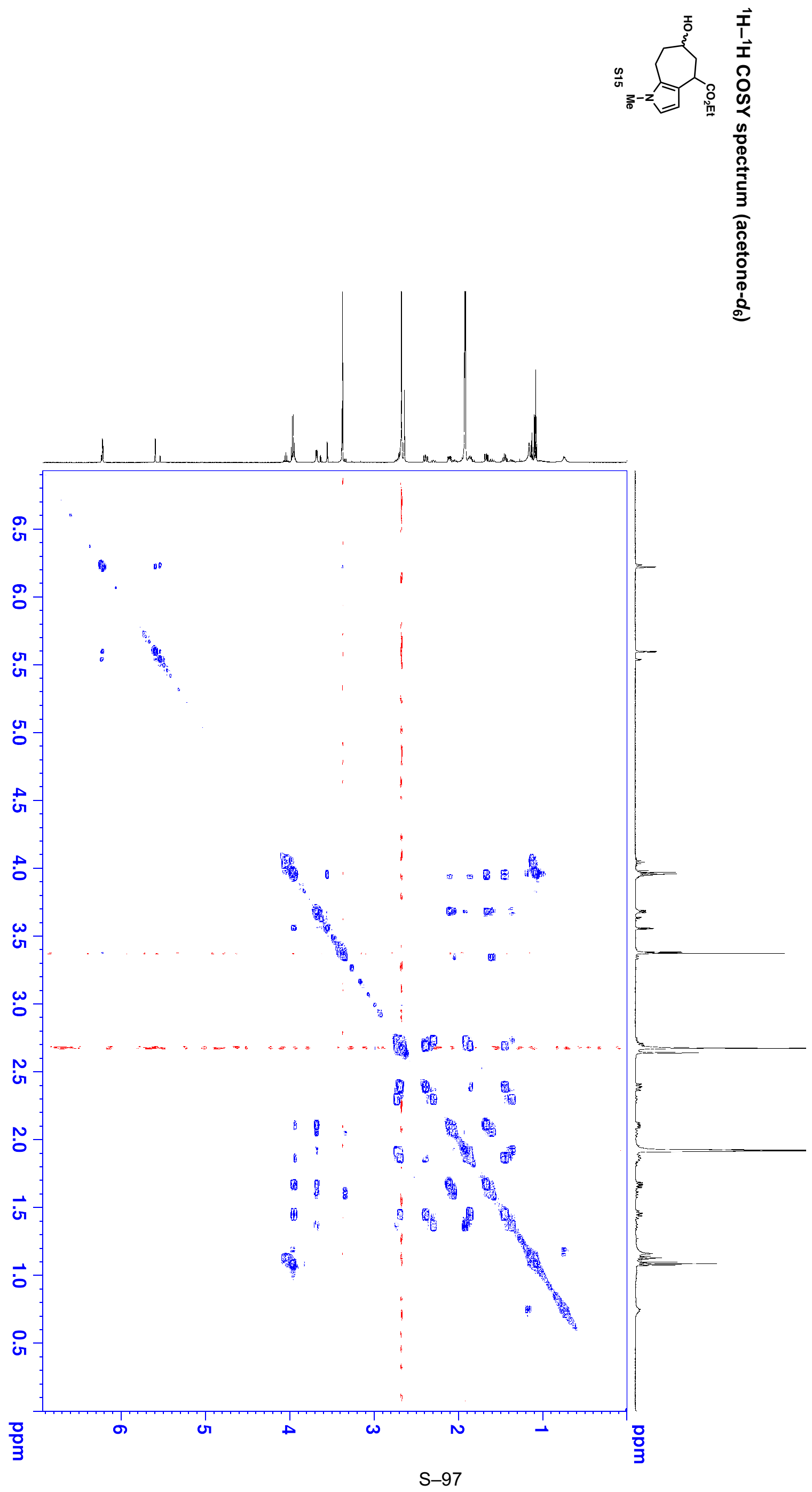




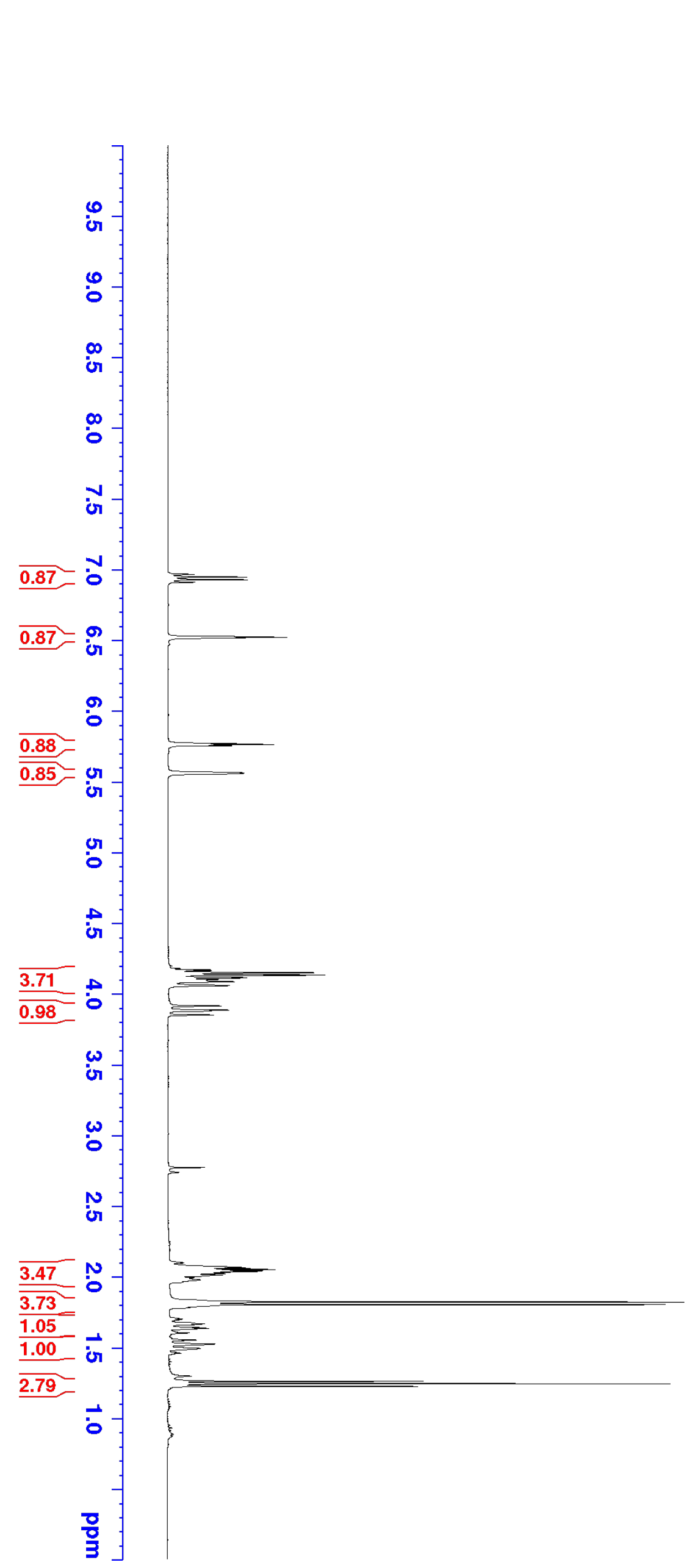

6.519

5.769

5.762

$-5.754$

$-5.562$

5.558

4.163

$-4.150$

4.146

4.133

$-4.115$

4.110

$-4.100$

$-4.098$

4.093

4.084

4.057

$-3.912$

3.884

3.879

3.849

2.067

2.061

2.055

2.049

2.044

2.038

2.029

2.023

2.019

2.008

1.991

1.983

1.976

1.819

1.801

$[1.670$

$\mp 1.666$

1.659

1.640

$<1.633$

- 1.628

$-1.550$

1.522

$[1.517$

1.491

1.486

1.258

‥241

1.223 


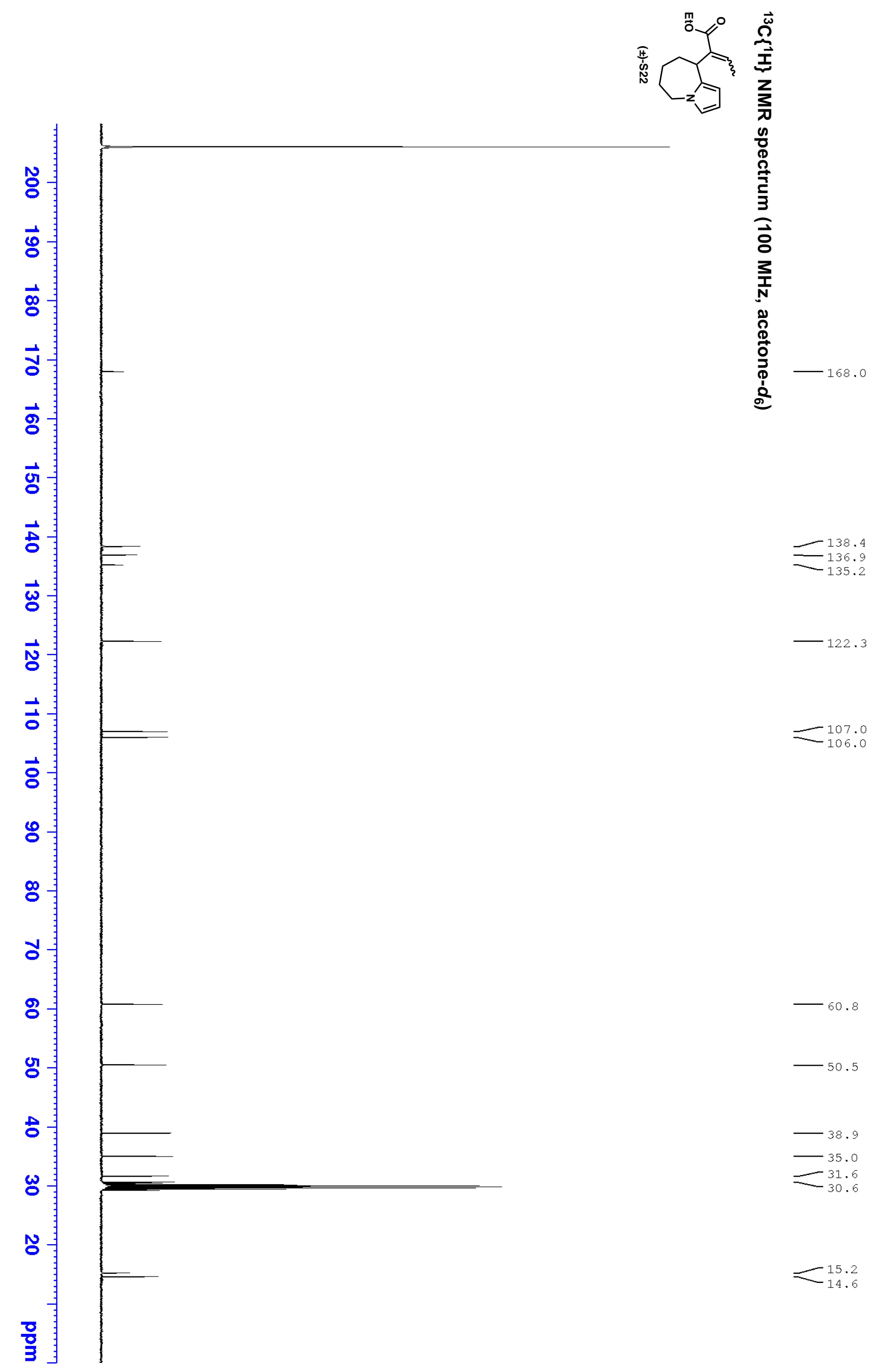




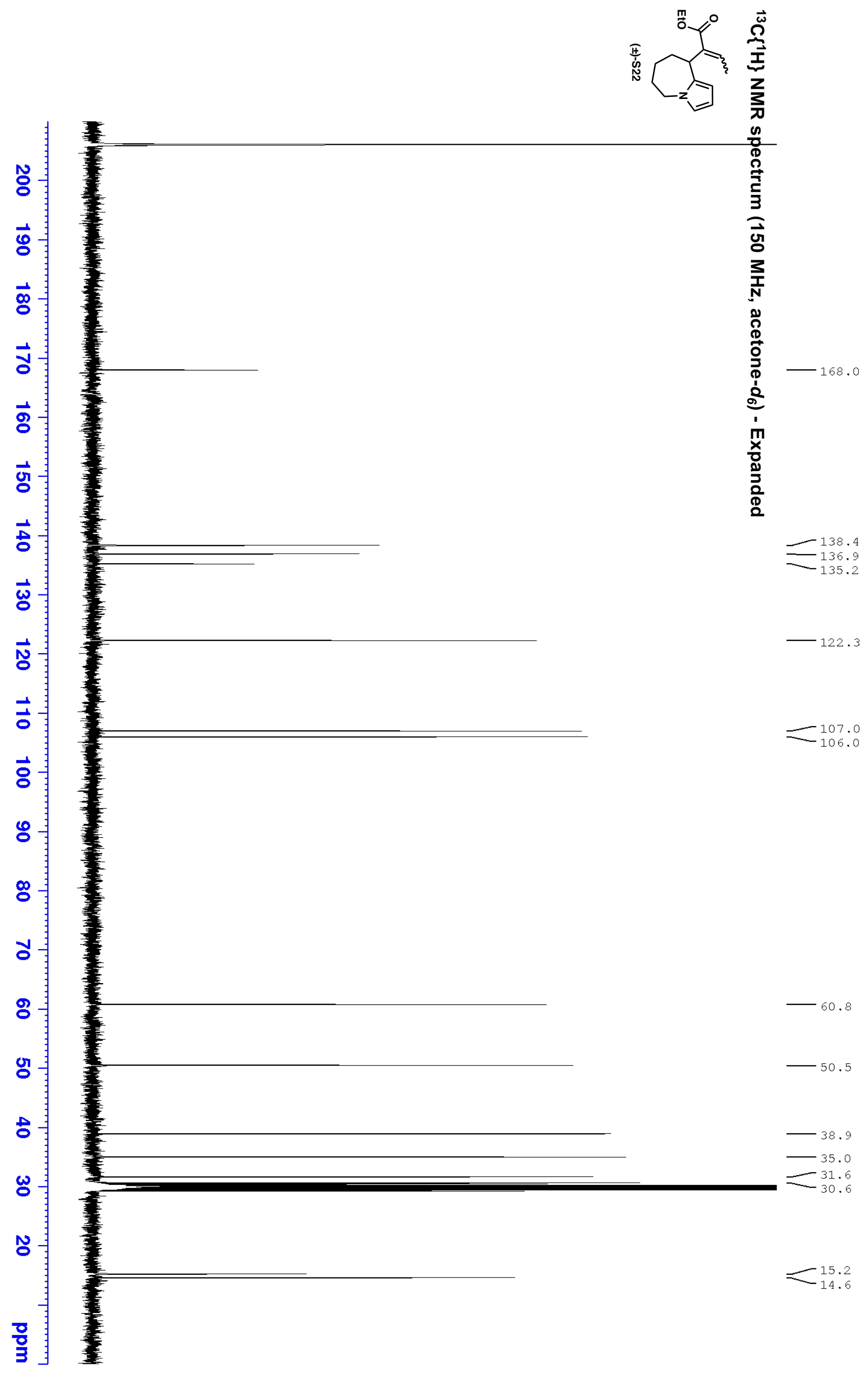




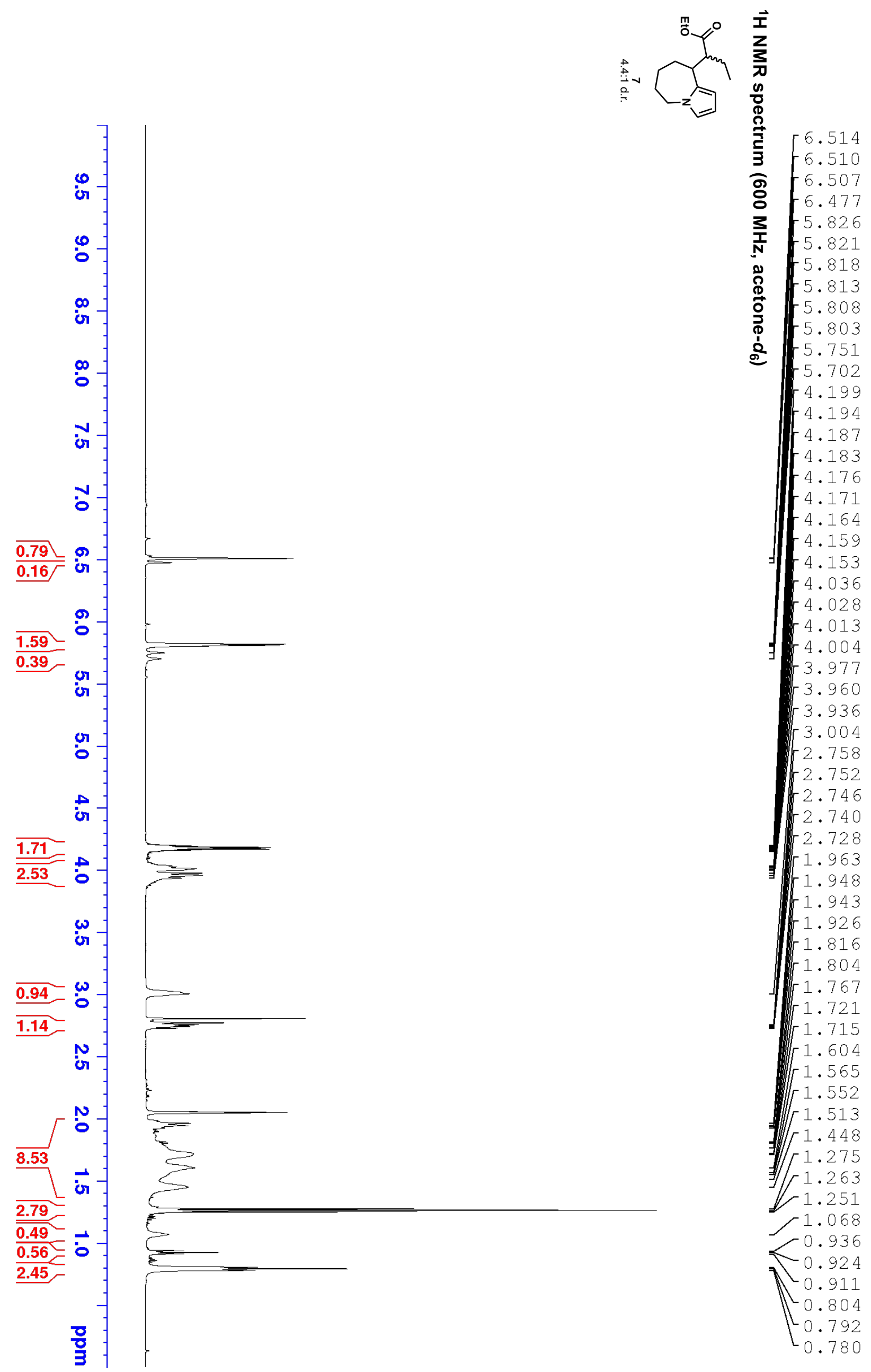




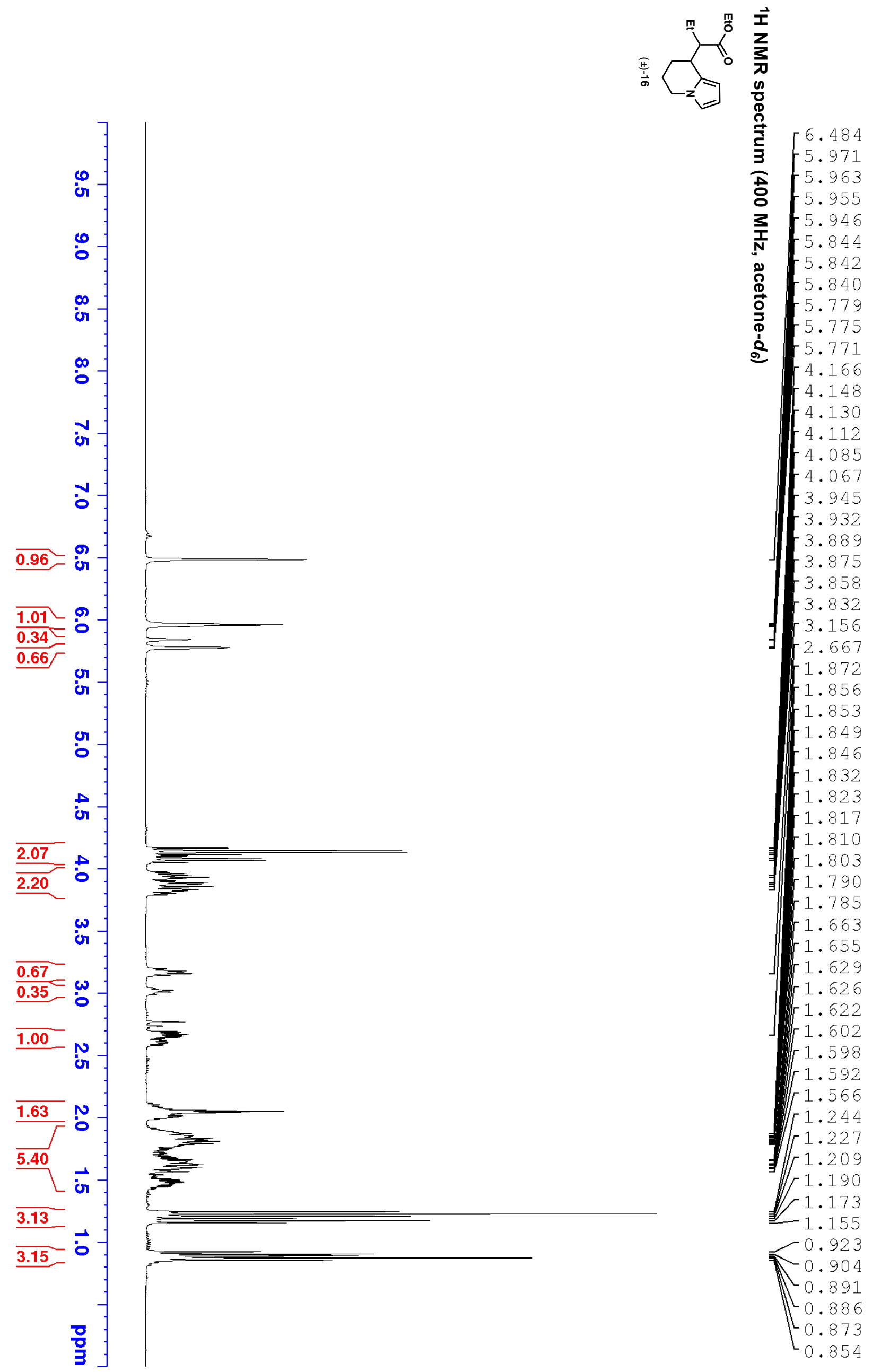




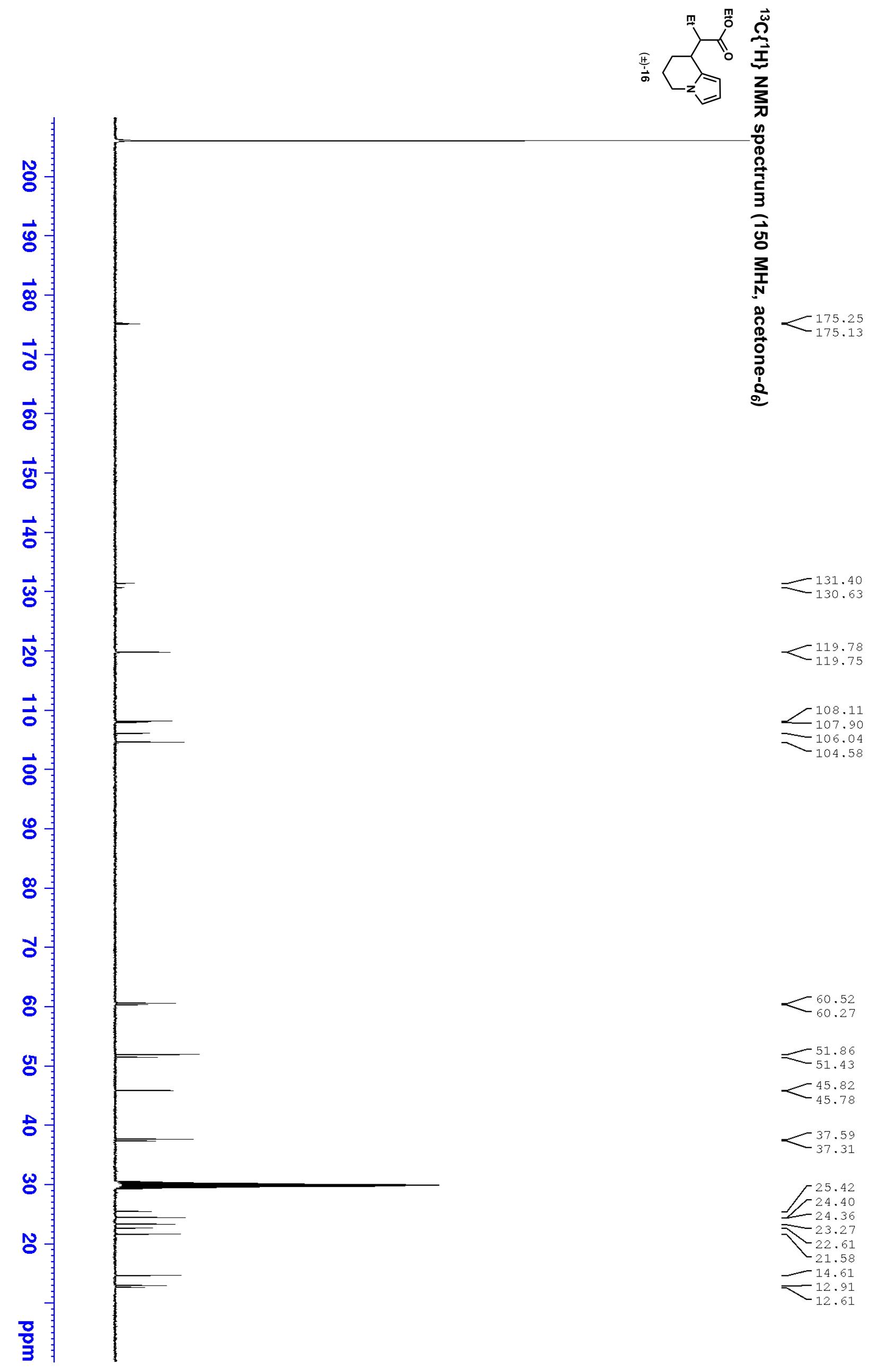




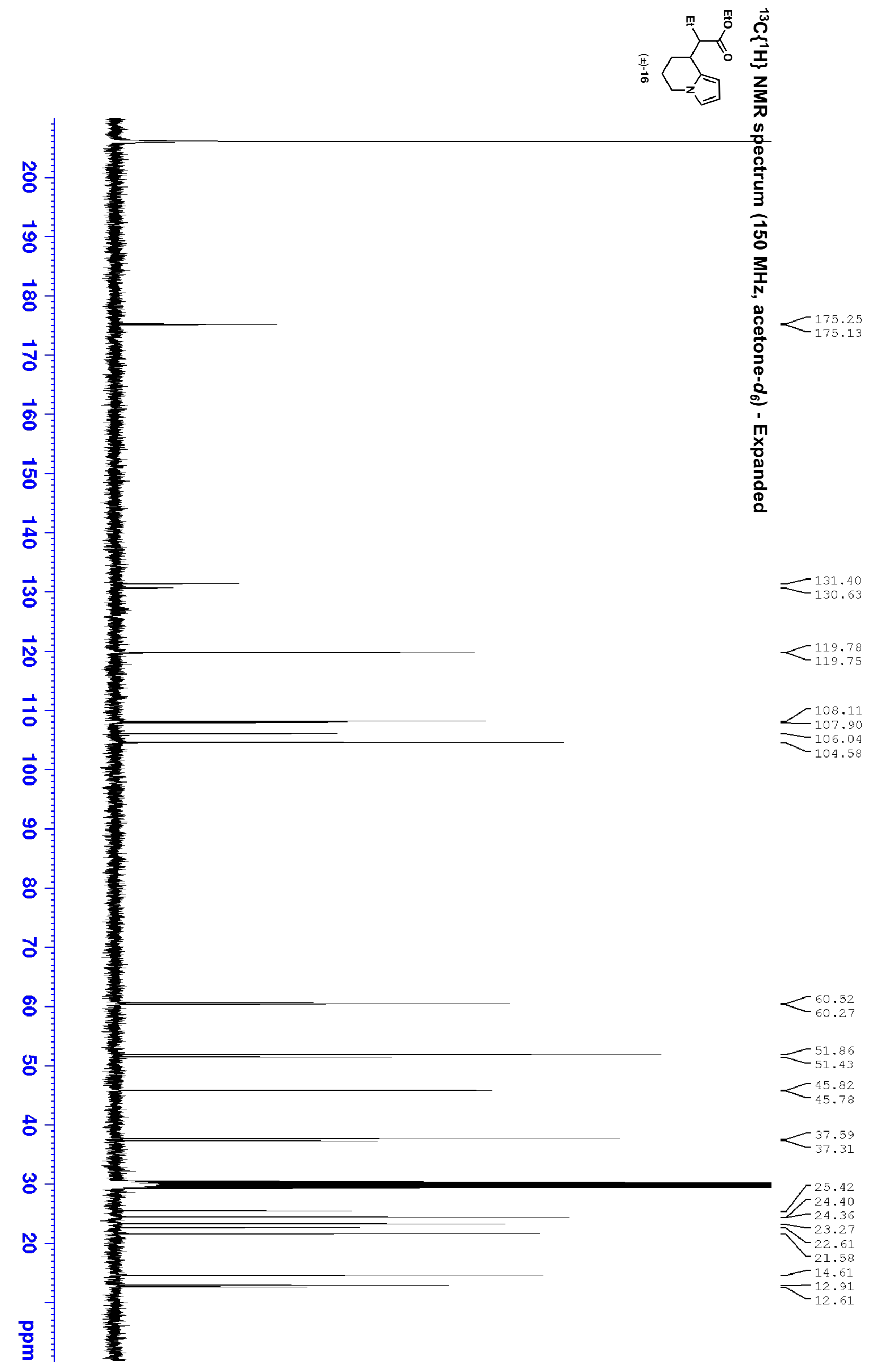




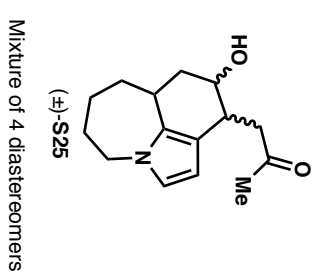

6.400

5.613

5.609

5.581

5.576

4.113

4.104

$-3.775$

3.766

$-3.747$

$-3.726$

$-3.602$

3.599

3.002

2.992

2.788

2.760

2.750

$-2.733$

2.723

2.616

2.604

2.588

2.576

2.495

2.490

2.483

2.478

2.181

2.163

2.150

2.077

2.017

2.011

$-2.009$

2.006

2.004

1.984

1.970

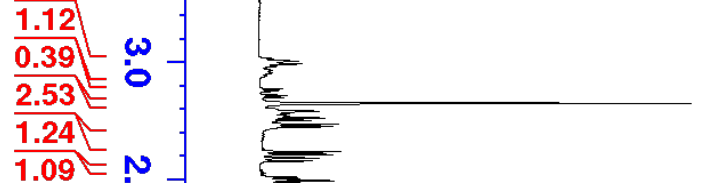

1.805

$[1.804$

$[1.749$

1.07 or

2.38

0.65 F

1.65

1.01 F वे

1.61.

4.30 $: 1$

0.51

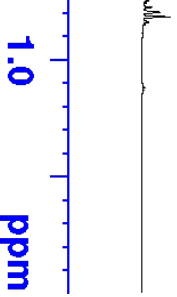

1.745

I. 1.742

1.737

1.726

1.719

1.715

1.628

1.616

1.604

1.602

1.580

1.579

1.334

1.330
1.334 


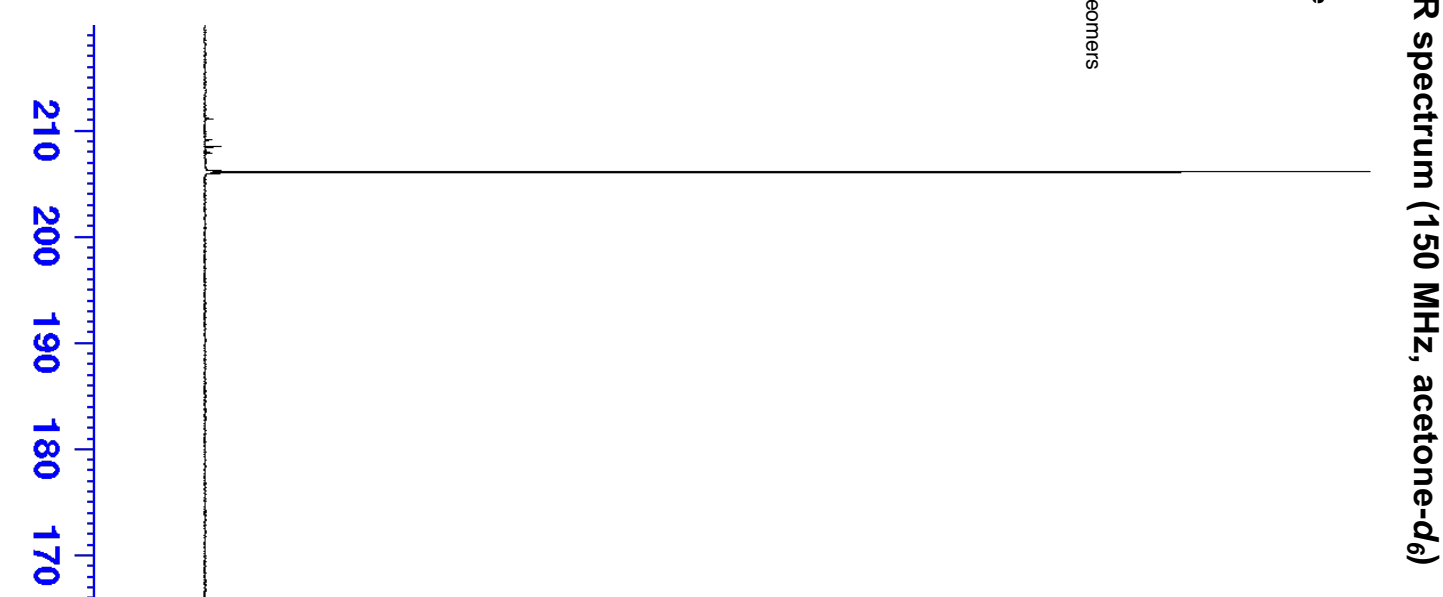

$-132.03$

$\begin{array}{r}122.06 \\ -\quad 121.19 \\ \hline\end{array}$

119.66
-119

-105.01
-104.46

$\overrightarrow{\mathrm{s}}$

8

ø

o

$-73.29$

70.52

51.42
50.45

49.44

48.52

43.26
42.85

I2.85

40.30
39.70

ป $\begin{array}{r}39.70 \\ 39.65\end{array}$

37.65
-37.33

$\begin{array}{r}-37.65 \\ -35.97 \\ \hline\end{array}$

33.71

33.51
-31.29
-31.17

$-31.17$

$\left[\begin{array}{r}30.77 \\ 30.74\end{array}\right.$

$\sqrt{30.34}$

$\left[\begin{array}{r}30.28 \\ 25.34\end{array}\right.$

25.34
20.08

몰 


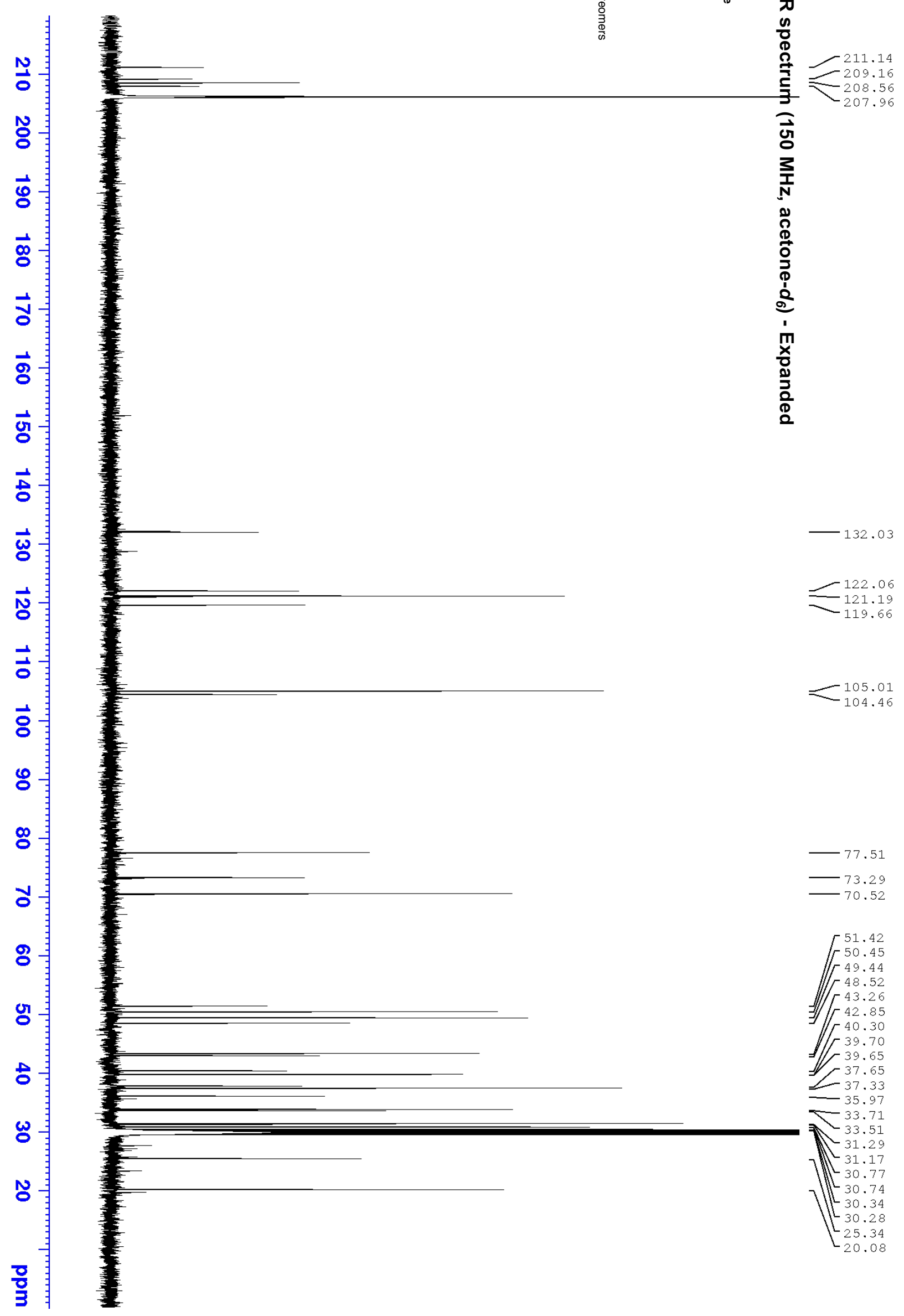

